\title{
Pd-Catalyzed Intramolecular $\alpha$-Allylic Alkylation of Ketones with Alkynes: Rapid and Stereodivergent Construction of [3.2.1] Bicycles
}

Pengfei Zheng ${ }^{\dagger, \neq}$, Chengpeng Wang ${ }^{\ddagger}$, Ying-Chun Chen ${ }^{\dagger}$ and Guangbin Dong* ${ }^{* \ddagger}$

${ }^{\dagger}$ College of Pharmacy, Third Military Medical University, Chongqing, 400038, China.

${ }^{\ddagger}$ Department of Chemistry, University of Chicago, Chicago, Illinois, 60637, United States

E-mail: gbdong@uchicago.edu.

\section{Table of contents}

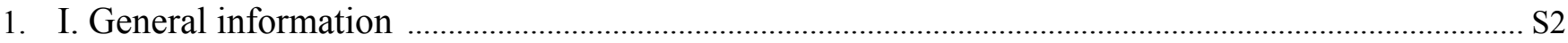

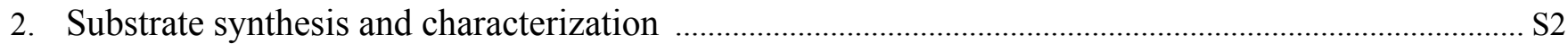

3. Additional control experiments and optimization of the reaction conditions ...................................... S18

4. Typical procedure for the substrate scope study .............................................................................. S23

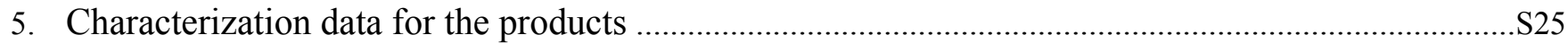

6. Derivatization of the cyclohexanone $\alpha$-allylic alkylation [3.2.1] bicycles ........................................ S50

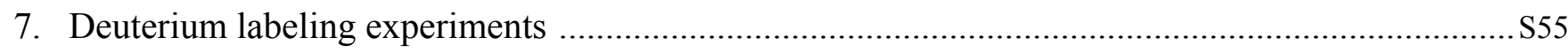

8. Crystal data and structural confirmation via 2-D NMR spectroscopy ………………………………... S61

9. Proposed stereochemical models for the stereodivergency ………......................................................S67

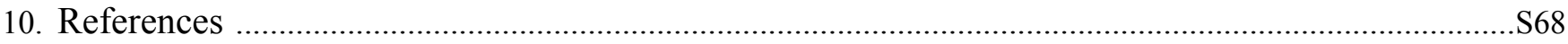

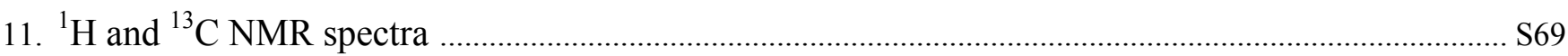




\section{General information}

Unless otherwise noted, all solvents were dried by filtration through a Pure-Solv MD-5 Solvent Purification System (Innovative Technology). Dioxane was distilled over sodium before use. CsOPiv was purchased from Sigma-Aldrich, dried in the oven at $140{ }^{\circ} \mathrm{C}$ and stored in the glovebox. All commercially available substrates were used without further purification. Reaction temperatures were reported as the temperatures of the bather surrounding the flasks or vials. Sensitive reagents and solvents were transferred under nitrogen into a nitrogen-filled glovebox with standard techniques. Analytical thin-layer chromatography (TLC) was carried out using $0.2 \mathrm{~mm}$ commercial silica gel plates (silica gel 60, F254, EMD chemical). Vials (15 x $45 \mathrm{~mm} 1$ dram $(4 \mathrm{~mL}) / 17$ x $60 \mathrm{~mm} 3$ dram (7.5mL) with PTFE lined cap attached) were purchased from Qorpak and flame-dried prior to use. High-resolution mass spectra (HRMS) were obtained on an Agilent 6224 Tof-MS spectrometer and are reported as $\mathrm{m} / \mathrm{z}$. X-ray diffraction data were collected at 100(2) K on a Bruker-Nonius Kappa CCD or Agilent Super Nova AtlasS2 CCD. Infrared spectra were recorded on a Nicolet 380 FTIR using neat thin film technique. Nuclear magnetic resonance spectra $\left({ }^{1} \mathrm{H}\right.$ NMR and ${ }^{13} \mathrm{C}$ NMR) were recorded with a Bruker Model DMX 500 or 400 . Chemical shifts are reported in parts per million (ppm, $\delta$ ), downfield from tetramethylsilane (TMS, $\delta=0.00 \mathrm{ppm})$ and are referenced to residual solvent $\left(\mathrm{CDCl}_{3}, \delta=7.26 \mathrm{ppm}\left({ }^{1} \mathrm{H}\right)\right.$ and $77.00 \mathrm{ppm}$ $\left.\left({ }^{13} \mathrm{C}\right)\right)$. Coupling constants were reported in Hertz $(\mathrm{Hz})$. Data for ${ }^{1} \mathrm{H}$ NMR spectra were reported as follows: chemical shift ( $\mathrm{ppm}$, referenced to protium, $\mathrm{s}=$ singlet, $\mathrm{d}=$ doublet, $\mathrm{t}=$ triplet, $\mathrm{q}=$ quartet, quin $=$ quintet, $\mathrm{dd}=$ doublet of doublets, $\mathrm{td}=$ triplet of doublets, $\mathrm{ddd}=$ doublet of doublet of doublets, $\mathrm{m}$ $=$ multiplet, coupling constant $(\mathrm{Hz})$, and integration).

\section{Substrate synthesis and characterization}

Compounds S1, ${ }^{1}$ S1y', ${ }^{2}$ S1z', ${ }^{3}$ S1aa, ${ }^{3}$ S1ab, ${ }^{1} \mathbf{S 1 a e}^{4}$ and $\mathbf{S 1 a g}^{9}$ were synthesized according to the previously reported literatures. S1af and S1ah are commercially available. All the substrates were prepared according to the following procedures.

\section{Procedure A:}

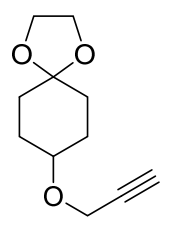

S1

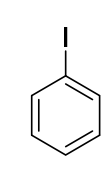

$\mathrm{Cul}(1 \mathrm{~mol} \%)$
$\underset{\mathrm{Pd}\left(\mathrm{PPh}_{3}\right)_{2} \mathrm{Cl}_{2}(2 \mathrm{~mol} \%)}{\longrightarrow}$

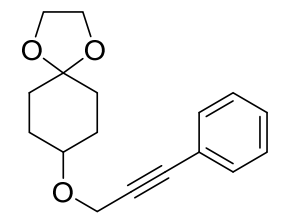

S1a

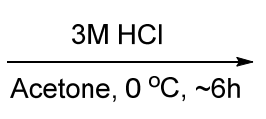

Acetone, $0^{\circ} \mathrm{C}, \sim 6 \mathrm{~h}$

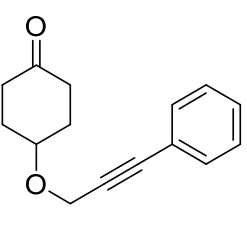

$1 a$

A $20 \mathrm{~mL}$ vial equipped with a stir bar was added $\mathrm{Pd}\left(\mathrm{PPh}_{3}\right)_{2} \mathrm{Cl}_{2}(2 \mathrm{~mol} \%, 0.08 \mathrm{mmol}, 56 \mathrm{mg}), \mathrm{CuI}(1$ $\mathrm{mol} \%, 0.04 \mathrm{mmol}, 5 \mathrm{mg}$ ) and stirred in $\mathrm{Et}_{3} \mathrm{~N}\left(15 \mathrm{~mL}\right.$ ) under $\mathrm{N}_{2}$. Iodobenzene (1.1 equiv, $4.4 \mathrm{mmol}, 898$ 
$\mathrm{mg}$ ) was added, followed by $\mathbf{S 1}$ (1 equiv, $4 \mathrm{mmol}, 784 \mathrm{mg}$ ). The reaction was stirred at $50{ }^{\circ} \mathrm{C}$ for about 8 hours. The reaction progress was monitored by TLC. Upon completion, the crude mixture was quenched with $\mathrm{NH}_{4} \mathrm{Cl}(30 \mathrm{~mL})$, extracted with EtOAc $(15 \mathrm{~mL} \times 3)$. The combined organic fractions were concentrated under vacue to give the crude S1a without further purification. S1a was directly added to $3 \mathrm{M} \mathrm{HCl}(10 \mathrm{~mL})$ and acetone $(10 \mathrm{~mL})$ in a $50 \mathrm{~mL}$ round-bottom flask, which was stirred at $0{ }^{\circ} \mathrm{C}$ for another $6 \mathrm{~h}$. After completion, the crude mixture was neutralized with saturated aq. $\mathrm{NaHCO}_{3}(50 \mathrm{~mL})$ and extracted with EtOAc (40 mL x 3). The combined organic fractions were washed with brine, dried over $\mathrm{MgSO}_{4}$, filtered and concentrated. The residue was purified by column chromatography over silica gel (hexane:EtOAc $=5: 1)$ to yield the desired aryl propargylic ketone 1a as a yellow oil in $85 \%$ yield ( 840 $\mathrm{mg}$ ) and stored in the freezer. $R_{f}=0.4$ (hexane:EtOAc $\left.=3: 1\right) .{ }^{1} \mathbf{H} \mathbf{~ N M R}\left(400 \mathrm{MHz}, \mathrm{CDCl}_{3}\right) \delta 7.49-7.39$ $(\mathrm{m}, 2 \mathrm{H}), 7.37-7.27(\mathrm{~m}, 3 \mathrm{H}), 4.47(\mathrm{~s}, 2 \mathrm{H}), 4.03(\mathrm{tt}, J=5.7,3.0 \mathrm{~Hz}, 1 \mathrm{H}), 2.69-2.57(\mathrm{~m}, 2 \mathrm{H}), 2.35-2.25$ $(\mathrm{m}, 2 \mathrm{H}), 2.23$ - $2.11(\mathrm{~m}, 2 \mathrm{H}), 2.06-1.92(\mathrm{~m}, 2 \mathrm{H}) .{ }^{13} \mathbf{C}$ NMR $\left(100 \mathrm{MHz}, \mathrm{CDCl}_{3}\right) \delta$ 211.03, 131.74, 128.57, 128.35, 122.49, 86.09, 85.22, 72.09, 56.52, 37.19, 30.45. IR (KBr, cm $\left.{ }^{-1}\right)$ 2948, 1716, 1260, 1097, 1065. HRMS calcd. $\mathrm{C}_{15} \mathrm{H}_{17} \mathrm{O}_{2}[\mathrm{M}+\mathrm{H}]^{+}:$229.1223. Found: 229.1229 .

\section{Procedure B:}

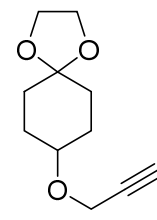

S1

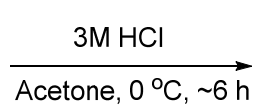

Acetone, $0^{\circ} \mathrm{C}, \sim 6 \mathrm{~h}$

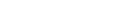

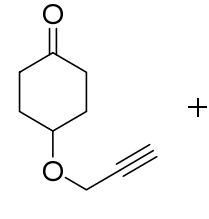

S1'

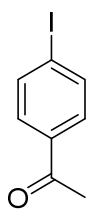

S1n

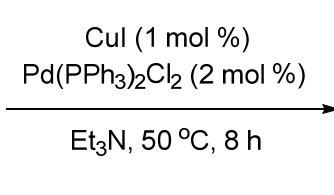

1n

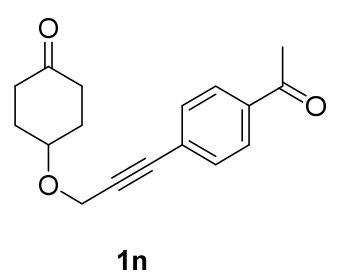

A $20 \mathrm{~mL}$ vial equipped with a stir bar was added $\mathbf{S 1}$ (393 $\mathrm{mg}, 2 \mathrm{mmol})$ in $3 \mathrm{M} \mathrm{HCl} \mathrm{(4} \mathrm{mL)} \mathrm{and} \mathrm{acetone} \mathrm{(4}$ $\mathrm{mL}$ ) at $0{ }^{\circ} \mathrm{C}$ for $\sim 6 \mathrm{~h}$. After completion as monitored by TLC, the crude mixture was neutralized with saturated $\mathrm{NaHCO}_{3}(25 \mathrm{~mL})$ and extracted with EtOAc $(15 \mathrm{~mL}$ x 3). The combined organic fractions were washed with brine, dried over $\mathrm{MgSO}_{4}$, filtered and concentrated. The residue was purified by column chromatography over silica gel (Hexane: EtOAc $=5: 1$ ) to yield the desired propargylic ketone S1' as a yellow oil in $90 \%$ yield $(274 \mathrm{mg})$. Then $\mathbf{S 1}$ ' was transferred to a $20 \mathrm{~mL}$ vial charged with $\mathrm{Pd}\left(\mathrm{PPh}_{3}\right)_{2} \mathrm{Cl}_{2}(2$ mol \%, $0.08 \mathrm{mmol}, 28 \mathrm{mg})$, CuI (1 mol \%, $0.04 \mathrm{mmol}, 2.5 \mathrm{mg})$ and stirred in $\mathrm{Et}_{3} \mathrm{~N}(8 \mathrm{~mL})$ under $\mathrm{N}_{2}$. 4Iodoacetophenone S1n (1.1 equiv, $2.2 \mathrm{mmol}, 735 \mathrm{mg}$ ) was added. The reaction was stirred at $50{ }^{\circ} \mathrm{C}$ for about 8 hours and monitored by TLC. Upon completion, the crude mixture was quenched with $\mathrm{NH}_{4} \mathrm{Cl}(20$ $\mathrm{mL})$ and extracted with EtOAc $(10 \mathrm{~mL} \times 3)$. The combined organic fractions were dried over $\mathrm{MgSO}_{4}$, filtered and concentrated. The residue was purified by column chromatography over silica gel (hexane:EtOAc $=5: 1$ ) to yield the desired $\mathbf{1 n}$ as a yellow solid in $65 \%$ yield $(316 \mathrm{mg})$. M.p. $68-70{ }^{\circ} \mathrm{C}$. $R_{f}=0.4$ (hexane/EtOAc $\left.=3: 1\right) .{ }^{1} \mathbf{H}$ NMR $\left(400 \mathrm{MHz}, \mathrm{CDCl}_{3}\right) \delta 7.98-7.83(\mathrm{~m}, 2 \mathrm{H}), 7.51(\mathrm{dd}, J=8.7,1.3$ 
$\mathrm{Hz}, 2 \mathrm{H}), 4.48(\mathrm{~s}, 2 \mathrm{H}), 4.01(\mathrm{dt}, J=5.6,2.8 \mathrm{~Hz}, 1 \mathrm{H}), 2.70-2.52(\mathrm{~m}, 5 \mathrm{H}), 2.38-2.24(\mathrm{~m}, 2 \mathrm{H}), 2.22-2.11$ $(\mathrm{m}, 2 \mathrm{H}), 2.06-1.93(\mathrm{~m}, 2 \mathrm{H}) .{ }^{13} \mathbf{C}$ NMR $\left(101 \mathrm{MHz}, \mathrm{CDCl}_{3}\right) \delta 210.80,197.24,136.53,131.85,128.24$, 127.32, 88.62, 85.26, 72.37, 56.47, 37.12, 30.40, 26.65. IR (KBr, cm $\left.{ }^{-1}\right)$ 3007, 1714, 1684, 1275, 1261. HRMS calcd. $\mathrm{C}_{17} \mathrm{H}_{19} \mathrm{O}_{3}[\mathrm{M}+\mathrm{H}]^{+}:$271.1329. Found: 271.1338 .

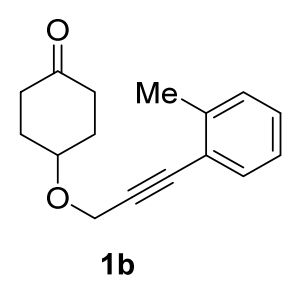

4-((3-(o-Tolyl)prop-2-yn-1-yl)oxy)cyclohexan-1-one (1b): Synthesized from S1 and 2-iodotoluene by following general procedure $A$ on a $4 \mathrm{mmol}$ scale. Yield: $83 \%$. Yellow oil. $R_{f}=0.4$ (hexane/EtOAc $=$ 3:1). ${ }^{1}$ H NMR $\left(400 \mathrm{MHz}, \mathrm{CDCl}_{3}\right) \delta 7.41(\mathrm{dd}, J=7.6,1.2 \mathrm{~Hz}, 1 \mathrm{H}), 7.25-7.18(\mathrm{~m}, 2 \mathrm{H}), 7.13$ (ddd, $J=8.1$, 4.9, $1.7 \mathrm{~Hz}, 1 \mathrm{H}), 4.52$ (s, 2H), 4.08 (dq, $J=5.7,2.9 \mathrm{~Hz}, 1 \mathrm{H}), 2.63$ (ddd, $J=15.4,10.3,5.8 \mathrm{~Hz}, 2 \mathrm{H}), 2.43$ (s, 3H), $2.30(\mathrm{dt}, J=14.7,5.9 \mathrm{~Hz}, 2 \mathrm{H}), 2.23-2.12(\mathrm{~m}, 2 \mathrm{H}), 2.07-1.94(\mathrm{~m}, 2 \mathrm{H}) .{ }^{13} \mathbf{C}$ NMR $(100 \mathrm{MHz}$, $\left.\mathrm{CDCl}_{3}\right) \delta 211.04,140.22,132.11,129.48,128.56,125.58,122.30,89.04,85.03,71.90,56.57,37.21$, 30.47, 20.72. IR $\left(\mathrm{KBr}, \mathrm{cm}^{-1}\right) 2945,1712,1275,1115,1065$. HRMS calcd. $\mathrm{C}_{16} \mathrm{H}_{19} \mathrm{O}_{2}[\mathrm{M}+\mathrm{H}]^{+}: 243.1380$. Found: 243.1381.

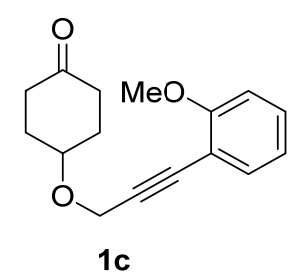

4-((3-(2-Methoxyphenyl)prop-2-yn-1-yl)oxy)cyclohexan-1-one (1c): Synthesized from S1 and 2iodoanisole by following general procedure A on a 3 mmol scale. Yield: 79 \%. Yellow solid. M.p. 34-36 ${ }^{\circ} \mathrm{C} . R_{f}=0.4$ (hexane/EtOAc = 3:1). ${ }^{1} \mathbf{H}$ NMR $\left(400 \mathrm{MHz}, \mathrm{CDCl}_{3}\right) \delta 7.40(\mathrm{dt}, J=7.6,1.8 \mathrm{~Hz}, 1 \mathrm{H}), 7.33$ $7.26(\mathrm{~m}, 1 \mathrm{H}), 6.99-6.79(\mathrm{~m}, 2 \mathrm{H}), 4.51(\mathrm{~s}, 2 \mathrm{H}), 4.06(\mathrm{dt}, J=5.9,2.8 \mathrm{~Hz}, 1 \mathrm{H}), 3.87$ (p, J=1.9 Hz, 3H), 2.64 (ddd, $J=15.1,10.5,5.5 \mathrm{~Hz}, 2 \mathrm{H}), 2.36-2.23$ (m, 2H), $2.24-2.14$ (m, 2H), 1.99 (qd, $J=9.3,4.5 \mathrm{~Hz}$, 2H). ${ }^{13} \mathrm{C}$ NMR (100 MHz, $\left.\mathrm{CDCl}_{3}\right) \delta 211.27,160.10,133.66,130.00,120.44,111.64,110.59,89.39$, 82.44, 72.15, 56.86, 55.74, 37.24, 30.54. IR $\left(\mathrm{KBr}, \mathrm{cm}^{-1}\right)$ 2942, 1712, 1492, 1263, 1063. HRMS calcd. $\mathrm{C}_{16} \mathrm{H}_{19} \mathrm{O}_{3}[\mathrm{M}+\mathrm{H}]^{+}:$259.1329. Found: 259.1339. 


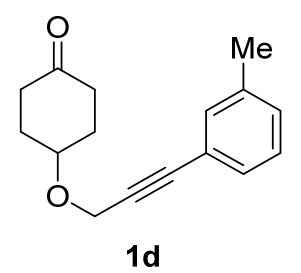

4-((3-(m-Tolyl)prop-2-yn-1-yl)oxy)cyclohexan-1-one (1d): Synthesized from S1 and 3-iodotoluene by following general procedure A on a $4 \mathrm{mmol}$ scale. Yield 76\%. Yellow oil. $R_{f}=0.4$ (hexane/EtOAc $\left.=3: 1\right)$. ${ }^{1}$ H NMR (400 MHz, $\left.\mathrm{CDCl}_{3}\right) \delta 7.28-7.13(\mathrm{~m}, 4 \mathrm{H}), 4.47(\mathrm{~s}, 2 \mathrm{H}), 4.04(\mathrm{tt}, J=5.7,3.0 \mathrm{~Hz}, 1 \mathrm{H}), 2.69$ - 2.52 (m, 2H), $2.33(\mathrm{~s}, 3 \mathrm{H}), 2.32-2.26(\mathrm{~m}, 2 \mathrm{H}), 2.17$ (dtdd, $J=13.1,5.9,4.4,1.2 \mathrm{~Hz}, 2 \mathrm{H}), 2.05-1.94(\mathrm{~m}, 2 \mathrm{H})$. ${ }^{13} \mathrm{C}$ NMR $\left(100 \mathrm{MHz}, \mathrm{CDCl}_{3}\right) \delta 211.06,138.05,132.30,129.46,128.81,128.24,122.29,86.26,84.83$, 72.03, 56.52, 37.19, 30.46, 21.22. IR $\left(\mathrm{KBr}, \mathrm{cm}^{-1}\right) 2946,1713,1275,1115,1065$. HRMS calcd. $\mathrm{C}_{16} \mathrm{H}_{19} \mathrm{O}_{2}$ $[\mathrm{M}+\mathrm{H}]^{+}: 243.1380$. Found: 243.1385 .

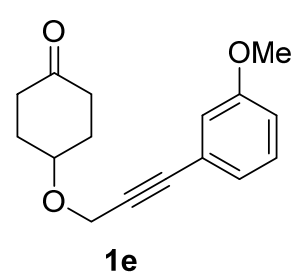

4-((3-(3-Methoxyphenyl)prop-2-yn-1-yl)oxy)cyclohexan-1-one (1e): Synthesized from S1 and 3iodoanisole by following general procedure $A$ on a 4 mmol scale. Yield $73 \%$. Yellow oil. $R_{f}=0.4$ (hexane/EtOAc = 3:1). ${ }^{1} \mathbf{H}$ NMR $\left(400 \mathrm{MHz}, \mathrm{CDCl}_{3}\right) \delta 7.25-7.19(\mathrm{~m}, 1 \mathrm{H}), 7.04(\mathrm{dt}, J=7.6,1.2 \mathrm{~Hz}, 1 \mathrm{H})$, $6.98(\mathrm{dd}, J=2.7,1.4 \mathrm{~Hz}, 1 \mathrm{H}), 6.89$ (ddd, $J=8.3,2.6,0.9 \mathrm{~Hz}, 1 \mathrm{H}), 4.47$ (s, 2H), 4.03 (tt, $J=5.7,3.0 \mathrm{~Hz}$, $1 \mathrm{H}), 3.80(\mathrm{~s}, 3 \mathrm{H}), 2.69-2.56(\mathrm{~m}, 2 \mathrm{H}), 2.34-2.26(\mathrm{~m}, 2 \mathrm{H}), 2.22-2.12(\mathrm{~m}, 2 \mathrm{H}), 2.05-1.95(\mathrm{~m}, 2 \mathrm{H}) .{ }^{13} \mathbf{C}$ NMR $\left(100 \mathrm{MHz}, \mathrm{CDCl}_{3}\right) \delta 211.11,159.30,129.43,124.26,123.46,116.69,115.03,85.99,85.04,72.11$, $56.49,55.29,37.17,30.43$. IR $\left(\mathrm{KBr}, \mathrm{cm}^{-1}\right) 2941,1712,1289,1204,1093,1064$. HRMS calcd. $\mathrm{C}_{16} \mathrm{H}_{19} \mathrm{O}_{3}$ $[\mathrm{M}+\mathrm{H}]^{+}:$259.1329. Found: 259.1337 .

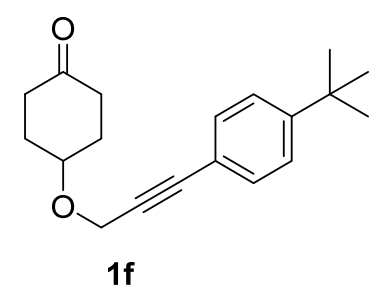

4-((3-(4-(tert-Butyl)phenyl)prop-2-yn-1-yl)oxy)cyclohexan-1-one (1f): Synthesized from S1 and 1-tertbutyl-4-iodobenzene by following general procedure $A$ on a 4 mmol scale. Yield $80 \%$. Yellow oil. $R_{f}=$ 
0.5 (hexane/EtOAc = 3:1). ${ }^{1} \mathbf{H}$ NMR $\left(400 \mathrm{MHz}, \mathrm{CDCl}_{3}\right) \delta 7.51-7.31(\mathrm{~m}, 4 \mathrm{H}), 4.47(\mathrm{~s}, 2 \mathrm{H}), 4.04(\mathrm{dt}, J=$ 5.7, $2.8 \mathrm{~Hz}, 1 \mathrm{H}), 2.63(\mathrm{ddd}, J=15.4,10.4,5.7 \mathrm{~Hz}, 2 \mathrm{H}), 2.30(\mathrm{dt}, J=14.4,5.7 \mathrm{~Hz}, 2 \mathrm{H}), 2.23$ - 2.11 (m, 2H), $2.00(\mathrm{ddt}, J=9.4,8.2,3.3 \mathrm{~Hz}, 2 \mathrm{H}), 1.31(\mathrm{~s}, 9 \mathrm{H}) .{ }^{13} \mathbf{C}$ NMR $\left(101 \mathrm{MHz}, \mathrm{CDCl}_{3}\right) \delta 211.09,151.88$, $131.49,125.35,119.45,86.22,84.51,72.01,56.58,37.21,34.80,31.16,30.48$. IR $\left(\mathrm{KBr}, \mathrm{cm}^{-1}\right) 2940,1714$, 1289, 1206, 1091, 1064. HRMS calcd. $\mathrm{C}_{19} \mathrm{H}_{25} \mathrm{O}_{2}[\mathrm{M}+\mathrm{H}]^{+}:$285.1849. Found: 285.1858.

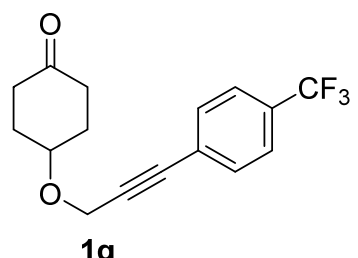

4-((3-(4-(Trifluoromethyl)phenyl)prop-2-yn-1-yl)oxy)cyclohexan-1-one (1g): Synthesized from S1 and 4-iodobenzotrifluoride by following general procedure $A$ on a 4 mmol scale. Yield $87 \%$. Brown oil. $R_{f}=0.4$ (hexane/EtOAc = 3:1). ${ }^{1} \mathbf{H}$ NMR $\left(400 \mathrm{MHz}, \mathrm{CDCl}_{3}\right) \delta 7.71-6.78(\mathrm{~m}, 4 \mathrm{H}), 4.48(\mathrm{~s}, 2 \mathrm{H}), 4.02(\mathrm{tt}$, $J=5.7,3.0 \mathrm{~Hz}, 1 \mathrm{H}), 2.85-2.51(\mathrm{~m}, 2 \mathrm{H}), 2.40-2.26(\mathrm{~m}, 2 \mathrm{H}), 2.23-2.11(\mathrm{~m}, 2 \mathrm{H}), 2.10-1.86(\mathrm{~m}, 2 \mathrm{H})$. ${ }^{13}$ C NMR $\left(100 \mathrm{MHz}, \mathrm{CDCl}_{3}\right) \delta 210.77,131.98,130.32\left(\mathrm{~d},{ }^{2} J_{\mathrm{C}-\mathrm{F}}=32.6 \mathrm{~Hz}\right), \delta 126.30\left(\mathrm{~d},{ }^{4} J_{\mathrm{C}-\mathrm{F}}=1.3 \mathrm{~Hz}\right)$, $125.29\left(\mathrm{q},{ }^{3} J_{\mathrm{C}-\mathrm{F}}=3.8 \mathrm{~Hz}\right), 123.82\left(\mathrm{~d},{ }^{1} J_{\mathrm{C}-\mathrm{F}}=272.3 \mathrm{~Hz}\right), 87.78,84.70,72.40,56.41,37.11,30.39 . \mathbf{I R}(\mathrm{KBr}$, $\left.\mathrm{cm}^{-1}\right) 2947,1713,1324,1126,1066$. HRMS calcd. $\mathrm{C}_{16} \mathrm{H}_{16} \mathrm{~F}_{3} \mathrm{O}_{2}[\mathrm{M}+\mathrm{H}]^{+}:$297.1097. Found: 297.1110.

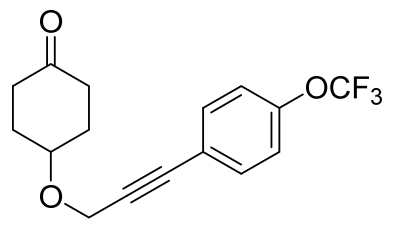

$1 \mathrm{~h}$

\section{4-((3-(4-(Trifluoromethoxy)phenyl)prop-2-yn-1-yl)oxy)cyclohexan-1-one (1h): Synthesized from S1} and 1-iodo-4-(trifluoromethoxy)benzene by following general procedure $A$ on a 4 mmol scale. Yield $60 \%$. Orange oil. $R_{f}=0.4$ (hexane/EtOAc = 3:1). ${ }^{1} \mathbf{H}$ NMR $\left(400 \mathrm{MHz}, \mathrm{CDCl}_{3}\right) \delta 7.47(\mathrm{~d}, J=8.8 \mathrm{~Hz}, 2 \mathrm{H}), 7.20$ $7.09(\mathrm{~m}, 2 \mathrm{H}), 4.46(\mathrm{~s}, 2 \mathrm{H}), 4.01(\mathrm{dq}, J=5.7,2.9 \mathrm{~Hz}, 1 \mathrm{H}), 2.87-2.50(\mathrm{~m}, 2 \mathrm{H}), 2.39-2.24(\mathrm{~m}, 2 \mathrm{H}), 2.22$ $2.10(\mathrm{~m}, 2 \mathrm{H}), 2.09-1.89(\mathrm{~m}, 2 \mathrm{H}) .{ }^{13} \mathbf{C}$ NMR $\left(100 \mathrm{MHz}, \mathrm{CDCl}_{3}\right) \delta 210.84,149.08\left(\mathrm{~d}, J_{\mathrm{C}-\mathrm{F}}=2.0 \mathrm{~Hz}\right)$, 133.28, 121.26, 120.84, 120.34 (q, $J=257.8 \mathrm{~Hz}), 86.16,84.63,72.24,56.40,37.11,30.39 . \mathbf{I R}\left(\mathrm{KBr}, \mathrm{cm}^{-1}\right)$ 2957, 1715, 1275, 1260, 1069. HRMS calcd. $\mathrm{C}_{16} \mathrm{H}_{16} \mathrm{~F}_{3} \mathrm{O}_{3}[\mathrm{M}+\mathrm{H}]^{+}:$313.1046. Found: 313.1049 . 


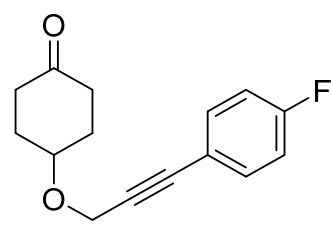

$1 \mathrm{i}$

4-((3-(4-Fluorophenyl)prop-2-yn-1-yl)oxy)cyclohexan-1-one (1i): Synthesized from S1 and 1-fluoro-4iodobenzene by following general procedure $A$ on a $4 \mathrm{mmol}$ scale. Yield $86 \%$. Orange oil. $R_{f}=0.4$ (hexane/EtOAc = 3:1). ${ }^{1}$ H NMR $\left(400 \mathrm{MHz}, \mathrm{CDCl}_{3}\right) \delta 7.46-7.36(\mathrm{~m}, 2 \mathrm{H}), 7.05-6.96(\mathrm{~m}, 2 \mathrm{H}), 4.44(\mathrm{~s}$, 2H), 4.01 (tt, $J=5.7,3.0 \mathrm{~Hz}, 1 \mathrm{H}), 2.68-2.52(\mathrm{~m}, 2 \mathrm{H}), 2.29$ (dtd, $J=14.9,5.7,5.1,1.5 \mathrm{~Hz}, 2 \mathrm{H}), 2.20$ $2.10(\mathrm{~m}, 2 \mathrm{H}), 2.05-1.94(\mathrm{~m}, 2 \mathrm{H}) .{ }^{13} \mathbf{C} \mathbf{N M R}\left(100 \mathrm{MHz}, \mathrm{CDCl}_{3}\right) \delta 210.94,162.64\left(\mathrm{~d},{ }^{1} J_{\mathrm{C}-\mathrm{F}}=249.9 \mathrm{~Hz}\right)$, $133.68\left(\mathrm{~d},{ }^{3} J_{\mathrm{C}-\mathrm{F}}=8.4 \mathrm{~Hz}\right), \delta 118.57\left(\mathrm{~d},{ }^{4} J_{\mathrm{C}-\mathrm{F}}=3.6 \mathrm{~Hz}\right), 115.65\left(\mathrm{~d},{ }^{2} J_{\mathrm{C}-\mathrm{F}}=22.1 \mathrm{~Hz}\right), 85.02,84.92\left(\mathrm{~d},{ }^{5} J_{\mathrm{C}-\mathrm{F}}\right.$ $=1.4 \mathrm{~Hz}), 72.16,56.46,37.15,30.42 . \mathbf{I R}\left(\mathrm{KBr}, \mathrm{cm}^{-1}\right)$ 2946, 1714, 1507, 1222, 1095. HRMS calcd. $\mathrm{C}_{15} \mathrm{H}_{16} \mathrm{FO}_{2}[\mathrm{M}+\mathrm{H}]^{+}:$247.1129. Found: 247.1137

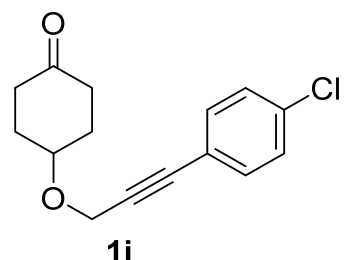

$1 \mathrm{j}$

4-((3-(4-Chlorophenyl)prop-2-yn-1-yl)oxy)cyclohexan-1-one (1j): Synthesized from S1 and 1-chloro4-iodobenzene by following general procedure A on a 4 mmol scale. Yield 79\%. Orange solid. M.p. 30$32{ }^{\circ} \mathrm{C} . R_{f}=0.35$ (hexane/EtOAc $\left.=3: 1\right) .{ }^{1} \mathbf{H}$ NMR $\left(400 \mathrm{MHz}, \mathrm{CDCl}_{3}\right) \delta 7.41-7.34(\mathrm{~m}, 2 \mathrm{H}), 7.32$ - $7.28(\mathrm{~m}$, 2H), $4.46(\mathrm{~s}, 2 \mathrm{H}), 4.01(\mathrm{dt}, J=5.6,2.8 \mathrm{~Hz}, 1 \mathrm{H}), 2.62(\mathrm{ddd}, J=15.5,10.5,5.8 \mathrm{~Hz}, 2 \mathrm{H}), 2.40-2.27(\mathrm{~m}$, 2H), $2.24-2.08(\mathrm{~m}, 2 \mathrm{H}), 2.07-1.95(\mathrm{~m}, 2 \mathrm{H}) .{ }^{13} \mathbf{C}$ NMR (101 MHz, $\left.\mathrm{CDCl}_{3}\right) \delta 210.89,134.66,132.98$, 128.71, 120.97, 86.22, 84.96, 72.23, 56.46, 37.14, 30.41. IR (KBr, cm $\left.{ }^{-1}\right)$ 2941, 1714, 1489, 1091, 1065. HRMS calcd. $\mathrm{C}_{15} \mathrm{H}_{16} \mathrm{ClO}_{2}[\mathrm{M}+\mathrm{H}]^{+}:$263.0833. Found: 263.0840 .

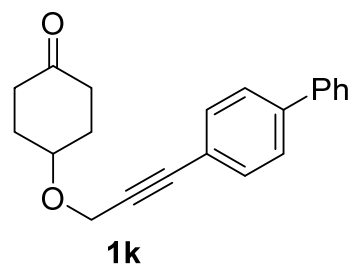

4-((3-([1,1'-Biphenyl]-4-yl)prop-2-yn-1-yl)oxy)cyclohexan-1-one (1k): Synthesized from S1 and 4iodobiphenyl by following general procedure A on a 4 mmol scale. Yield 74\%. Brown solid. M.p. 80-82 
${ }^{\circ} \mathrm{C} . \quad R_{f}=0.4$ (hexane/EtOAc $\left.=3: 1\right) .{ }^{1} \mathbf{H}$ NMR $\left(400 \mathrm{MHz}, \mathrm{CDCl}_{3}\right) \delta 7.65-7.49(\mathrm{~m}, 6 \mathrm{H}), 7.49-7.41(\mathrm{~m}$, 2H), 7.40 - $7.30(\mathrm{~m}, 1 \mathrm{H}), 4.50(\mathrm{~s}, 2 \mathrm{H}), 4.06(\mathrm{dt}, J=5.6,2.8 \mathrm{~Hz}, 1 \mathrm{H}), 2.73$ - $2.56(\mathrm{~m}, 2 \mathrm{H}), 2.37$ - 2.27 (m, 2H), 2.24 - $2.13(\mathrm{~m}, 2 \mathrm{H}), 2.07-1.93(\mathrm{~m}, 2 \mathrm{H}) .{ }^{13} \mathbf{C} \mathbf{N M R}\left(101 \mathrm{MHz}, \mathrm{CDCl}_{3}\right) \delta$ 211.03, 141.35, 140.23, 132.18, 128.88, 127.73, 127.03, 121.36, 85.98, 85.85, 72.13, 56.58, 37.20, 30.47. IR (KBr, cm $\left.{ }^{-1}\right) 2954$, 1712, 1275, 1261, 1065. HRMS calcd. $\mathrm{C}_{21} \mathrm{H}_{21} \mathrm{O}_{2}[\mathrm{M}+\mathrm{H}]^{+}:$305.1536. Found: 305.1546.

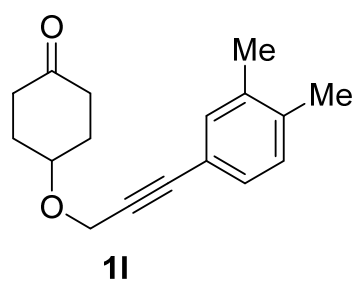

4-((3-(3,4-Dimethylphenyl)prop-2-yn-1-yl)oxy)cyclohexan-1-one (11): Synthesized from S1 and 1iodo-3,4-dimethylbenzene by following general procedure $A$ on a 4 mmol scale. Yield 79\%. Yellow oil. $R_{f}=0.4($ hexane/EtOAc $=3: 1) .{ }^{1} \mathbf{H}$ NMR $\left(400 \mathrm{MHz}, \mathrm{CDCl}_{3}\right) \delta 7.23(\mathrm{~d}, J=1.7 \mathrm{~Hz}, 1 \mathrm{H}), 7.18(\mathrm{dd}, J=7.8$, $1.7 \mathrm{~Hz}, 1 \mathrm{H}), 7.07$ (d, $J=7.7 \mathrm{~Hz}, 1 \mathrm{H}), 4.46(\mathrm{~s}, 2 \mathrm{H}), 4.03$ (tt, $J=5.8,3.0 \mathrm{~Hz}, 1 \mathrm{H}), 2.72-2.52$ (m, 2H), 2.33 - 2.27 (m, 2H), $2.25(\mathrm{~s}, 3 \mathrm{H}), 2.23(\mathrm{~s}, 3 \mathrm{H}), 2.21$ - 2.11 (m, 2H), 2.04 - 1.94 (m, 2H). ${ }^{13} \mathbf{C}$ NMR (101 MHz, $\left.\mathrm{CDCl}_{3}\right) \delta 211.13,137.53,136.68,132.77,129.64,129.19,119.70,86.37,84.23,71.97,56.57,37.20$, 30.47, 19.77, 19.58. IR $\left(\mathrm{KBr}, \mathrm{cm}^{-1}\right)$ 2941, 1713, 1275, 1261, 1085. HRMS calcd. $\mathrm{C}_{17} \mathrm{H}_{21} \mathrm{O}_{2}$ $[\mathrm{M}+\mathrm{H}]^{+}: 257.1536$. Found: 257.1541 .

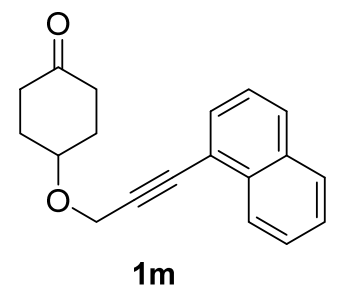

4-((3-(Naphthalen-1-yl)prop-2-yn-1-yl)oxy)cyclohexan-1-one (1m): Synthesized from S1 and 1iodonaphthalene by following general procedure A on a 4 mmol scale. Yield 74\%. Brown solid. M.p. $103-105{ }^{\circ} \mathrm{C} . \quad R_{f}=0.45$ (hexane/EtOAc $\left.=3: 1\right) .{ }^{1} \mathbf{H}$ NMR $\left(400 \mathrm{MHz}, \mathrm{CDCl}_{3}\right) \delta 8.31$ (ddt, $J=8.3,1.5,0.8$ $\mathrm{Hz}, 1 \mathrm{H}), 7.95-7.80$ (m, 2H), 7.69 (dd, $J=7.2,1.2 \mathrm{~Hz}, 1 \mathrm{H}), 7.55$ (dddd, $J=19.8,8.2,6.8,1.4 \mathrm{~Hz}, 2 \mathrm{H})$, $7.43(\mathrm{dd}, J=8.3,7.1 \mathrm{~Hz}, 1 \mathrm{H}), 4.64(\mathrm{~s}, 2 \mathrm{H}), 4.15(\mathrm{dt}, J=5.7,2.7 \mathrm{~Hz}, 1 \mathrm{H}), 2.76-2.53(\mathrm{~m}, 2 \mathrm{H}), 2.39$ - 2.27 (m, 2H), 2.28 - 2.19 (m, 2H), 2.13 - 1.90 (m, 2H). $\left.{ }^{13} \mathbf{C ~ N M R ~ ( 1 0 1 ~ M H z , ~} \mathrm{CDCl}_{3}\right) \delta 211.01,133.31,133.15$, 130.76, 129.06, 128.36, 126.86, 126.47, 125.94, 125.19, 120.14, 90.09, 84.23, 72.12, 56.72, 37.22, 30.52. IR $\left(\mathrm{KBr}, \mathrm{cm}^{-1}\right) 3004,1713,1275,1261,1062$. HRMS calcd. $\mathrm{C}_{19} \mathrm{H}_{19} \mathrm{O}_{2}[\mathrm{M}+\mathrm{H}]^{+}:$279.1380. Found: 279.1389 


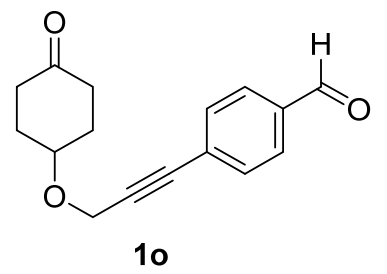

4-(3-(4-Oxocyclohexyl)oxy)prop-1-yn-1-yl)benzaldehyde (10): Synthesized from S1' and 4iodobenzaldehyde by following general procedure B on a $3 \mathrm{mmol}$ scale. Yield 69\%. Yellow solid. M.p. $64-66{ }^{\circ} \mathrm{C} . \quad R_{f}=0.4($ hexane/EtOAc $=3: 1) .{ }^{1} \mathbf{H}$ NMR $\left(400 \mathrm{MHz}, \mathrm{CDCl}_{3}\right) \delta 10.01(\mathrm{~s}, 1 \mathrm{H}), 7.84(\mathrm{~d}, J=8.3$ $\mathrm{Hz}, 2 \mathrm{H}), 7.59$ (d, $J=8.3 \mathrm{~Hz}, 2 \mathrm{H}), 4.50(\mathrm{~s}, 2 \mathrm{H}), 4.02(\mathrm{tt}, J=5.7,3.0 \mathrm{~Hz}, 1 \mathrm{H}), 2.81-2.47$ (m, 2H), 2.36 $2.26(\mathrm{~m}, 2 \mathrm{H}), 2.24-2.10(\mathrm{~m}, 2 \mathrm{H}), 2.01$ (dddd, $J=14.9,10.7,5.3,3.2 \mathrm{~Hz}, 2 \mathrm{H}) .{ }^{13} \mathbf{C}$ NMR (101 MHz, $\left.\mathrm{CDCl}_{3}\right) \delta 210.85,191.37,135.71,132.26,129.55,128.72,89.37,85.17,72.43,56.46,37.10,30.39$. IR $\left(\mathrm{KBr}, \mathrm{cm}^{-1}\right) 3005,1702,1602,1275,1060$. HRMS calcd. $\mathrm{C}_{16} \mathrm{H}_{17} \mathrm{O}_{3}[\mathrm{M}+\mathrm{H}]^{+}: 257.1172$. Found: 257.1181.

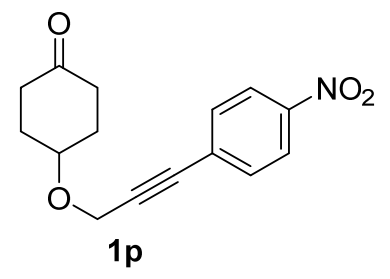

4-((3-(4-Nitrophenyl)prop-2-yn-1-yl)oxy)cyclohexan-1-one (1p): Synthesized from S1 and 1-iodo-4nitrobenzene by following general procedure A on a 4 mmol scale. Yield 64\%. Yellow solid. M.p. 82-84 ${ }^{\circ} \mathrm{C} . \quad R_{f}=0.25($ hexane/EtOAc $=3: 1) .{ }^{1} \mathbf{H}$ NMR $\left(400 \mathrm{MHz}, \mathrm{CDCl}_{3}\right) \delta 8.18(\mathrm{~d}, J=8.9 \mathrm{~Hz}, 2 \mathrm{H}), 7.58(\mathrm{~d}, J=$ $8.9 \mathrm{~Hz}, 2 \mathrm{H}), 4.49(\mathrm{~s}, 2 \mathrm{H}), 4.00(\mathrm{tt}, J=5.7,3.0 \mathrm{~Hz}, 1 \mathrm{H}), 2.90-2.51(\mathrm{~m}, 2 \mathrm{H}), 2.37-2.25(\mathrm{~m}, 2 \mathrm{H}), 2.23$ $2.11(\mathrm{~m}, 2 \mathrm{H}), 2.01$ (dddd, $J=14.9,10.6,5.3,3.0 \mathrm{~Hz}, 2 \mathrm{H}) .{ }^{13} \mathbf{C} \mathbf{N M R}\left(101 \mathrm{MHz}, \mathrm{CDCl}_{3}\right) \delta 210.62,147.29$, $132.49,129.34,123.61,90.71,84.17,72.58,56.39,37.07,30.35 . \mathbf{I R}\left(\mathrm{KBr}, \mathrm{cm}^{-1}\right) 2948,1712,1518,1343$, 1068. HRMS calcd. $\mathrm{C}_{15} \mathrm{H}_{16} \mathrm{NO}_{4}[\mathrm{M}+\mathrm{H}]^{+}:$274.1074. Found: 274.1084.

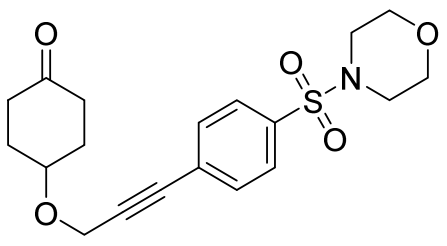

$1 q$

4-((3-(4-(Morpholinosulfonyl)phenyl)prop-2-yn-1-yl)oxy)cyclohexan-1-one (1q): Synthesized from S1' and 4-((4-iodophenyl)sulfonyl)morpholine by following general procedure B on a $1 \mathrm{mmol}$ scale. Yield $54 \%$. White solid. M.p. $74-76{ }^{\circ} \mathrm{C} . R_{f}=0.25$ (hexane/EtOAc $\left.=1: 1\right) .{ }^{1} \mathbf{H}$ NMR $\left(400 \mathrm{MHz}, \mathrm{CDCl}_{3}\right) \delta$ 
7.83 - $7.63(\mathrm{~m}, 2 \mathrm{H}), 7.64-7.52(\mathrm{~m}, 2 \mathrm{H}), 4.49(\mathrm{~s}, 2 \mathrm{H}), 4.01(\mathrm{tt}, J=5.7,3.0 \mathrm{~Hz}, 1 \mathrm{H}), 3.84-3.62(\mathrm{~m}, 4 \mathrm{H})$, $3.19-2.86(\mathrm{~m}, 4 \mathrm{H}), 2.62(\mathrm{ddd}, J=15.5,10.5,5.8 \mathrm{~Hz}, 2 \mathrm{H}), 2.39-2.25(\mathrm{~m}, 2 \mathrm{H}), 2.23-2.11(\mathrm{~m}, 2 \mathrm{H}), 2.08$ - 1.89 (m, 2H). ${ }^{13} \mathbf{C}$ NMR (101 MHz, $\left.\mathrm{CDCl}_{3}\right) \delta 210.69,134.81,132.27,127.80,127.65,89.34,84.34$, 72.50, 66.07, 56.40, 45.96, 37.09, 30.38. IR $\left(\mathrm{KBr}, \mathrm{cm}^{-1}\right)$ 3004, 1713, 1275, 1261, 1023. HRMS calcd. $\mathrm{C}_{19} \mathrm{H}_{24} \mathrm{NO}_{5} \mathrm{~S}[\mathrm{M}+\mathrm{H}]^{+}:$378.1370. Found: 378.1371 .

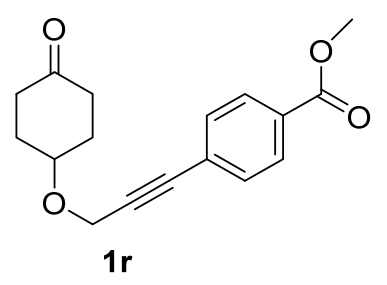

Methyl 4-(3-((4-oxocyclohexyl)oxy)prop-1-yn-1-yl)benzoate (1r): Synthesized from S1 and methyl 4iodobenzoate by following general procedure A on a 4 mmol scale. Yield $71 \%$. Yellow solid. M.p. 82-84 ${ }^{\circ} \mathrm{C} . \quad R_{f}=0.25($ hexane/EtOAc $=3: 1) .{ }^{1} \mathbf{H}$ NMR $\left(400 \mathrm{MHz}, \mathrm{CDCl}_{3}\right) \delta 8.07-7.89(\mathrm{~m}, 2 \mathrm{H}), 7.58-7.40(\mathrm{~m}$, 2H), $4.48(\mathrm{~s}, 2 \mathrm{H}), 4.02(\mathrm{tt}, J=5.8,3.0 \mathrm{~Hz}, 1 \mathrm{H}), 3.92(\mathrm{~s}, 3 \mathrm{H}), 2.74-2.52(\mathrm{~m}, 2 \mathrm{H}), 2.37-2.24(\mathrm{~m}, 2 \mathrm{H})$, 2.22 - $2.10(\mathrm{~m}, 2 \mathrm{H}), 2.07-1.91$ (m, 2H). ${ }^{13} \mathrm{C}$ NMR (101 MHz, $\left.\mathrm{CDCl}_{3}\right) \delta 210.83,166.43,131.65,129.87$, 129.50, 127.14, 88.26, 85.31, 72.31, 56.45, 52.29, 37.13, 30.40. IR $\left(\mathrm{KBr}, \mathrm{cm}^{-1}\right) 2953,1719,1276,1261$, 1062. HRMS calcd. $\mathrm{C}_{17} \mathrm{H}_{19} \mathrm{O}_{4}[\mathrm{M}+\mathrm{H}]^{+}: 287.1278$. Found: 287.1288 .

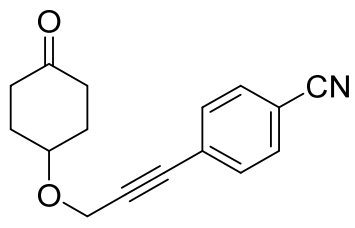

$1 \mathrm{~s}$

4-(3-(4-Oxocyclohexyl)oxy)prop-1-yn-1-yl)benzonitrile (1s): Synthesized from $\mathbf{S 1}$ and 4iodobenzonitrile by following general procedure A on a $3 \mathrm{mmol}$ scale. Yield 76\%. Yellow solid. M.p. 75$77{ }^{\circ} \mathrm{C} . \quad R_{f}=0.25\left(\right.$ hexane/EtOAc = 3:1). ${ }^{1} \mathbf{H}$ NMR $\left(400 \mathrm{MHz}, \mathrm{CDCl}_{3}\right) \delta 7.66-7.56(\mathrm{~m}, 2 \mathrm{H}), 7.55-7.45$ $(\mathrm{m}, 2 \mathrm{H}), 4.48(\mathrm{~d}, J=3.3 \mathrm{~Hz}, 2 \mathrm{H}), 4.00(\mathrm{dq}, J=5.7,2.8 \mathrm{~Hz}, 1 \mathrm{H}), 2.71-2.53(\mathrm{~m}, 2 \mathrm{H}), 2.30$ (dtd, $J=14.9$, 5.2, 4.6, $1.6 \mathrm{~Hz}, 2 \mathrm{H}), 2.22$ - $2.08(\mathrm{~m}, 2 \mathrm{H}), 2.09-1.90(\mathrm{~m}, 2 \mathrm{H}) .{ }^{13} \mathbf{C} \mathbf{N M R}\left(101 \mathrm{MHz}, \mathrm{CDCl}_{3}\right) \delta 210.67$, 132.25, 132.06, 127.38, 118.32, 112.01, 89.83, 84.41, 72.52, 56.39, 37.08, 30.36. IR (KBr, cm $\left.{ }^{-1}\right) 2955$, 2228, 1713, 1275, 1261. HRMS calcd. $\mathrm{C}_{16} \mathrm{H}_{16} \mathrm{NO}_{2}[\mathrm{M}+\mathrm{H}]^{+}: 254.1176$. Found: 254.1183 


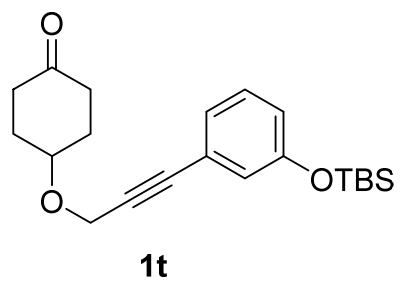

4-((3-(3-((tert-Butyldimethylsilyl)oxy)phenyl)prop-2-yn-1-yl)oxy)cyclohexan-1-one (1t): Synthesized from S1' and 3-(tert-butyldimethylsilyloxy)iodobenzene by following general procedure B on a $1.5 \mathrm{mmol}$ scale. Yield 65\%. Yellow oil. $R_{f}=0.4$ (hexane/EtOAc $\left.=3: 1\right) .{ }^{1} \mathbf{H}$ NMR $\left(400 \mathrm{MHz}, \mathrm{CDCl}_{3}\right) \delta 7.22-7.11$ (m, 1H), $7.04(\mathrm{dt}, J=7.7,1.3 \mathrm{~Hz}, 1 \mathrm{H}), 6.91(\mathrm{dd}, J=2.3,1.4 \mathrm{~Hz}, 1 \mathrm{H}), 6.82(\mathrm{ddd}, J=8.1,2.5,1.1 \mathrm{~Hz}, 1 \mathrm{H})$, $4.46(\mathrm{~s}, 2 \mathrm{H}), 4.03(\mathrm{tt}, J=5.7,2.9 \mathrm{~Hz}, 1 \mathrm{H}), 2.71-2.52(\mathrm{~m}, 2 \mathrm{H}), 2.39-2.24(\mathrm{~m}, 2 \mathrm{H}), 2.24-2.11(\mathrm{~m}, 2 \mathrm{H})$, 2.07 - 1.94 (m, 2H), 0.98 (s, 9H), 0.19 (s, 6H). $\left.{ }^{13} \mathbf{C ~ N M R ~ ( 1 0 1 ~ M H z , ~} \mathrm{CDCl}_{3}\right) \delta 211.02,155.47,129.41$, $124.93,123.46,123.25,120.87,85.92,84.96,72.13,56.52,37.19,30.46,25.64,18.19,-4.42 . \mathbf{I R}(\mathrm{KBr}$, $\left.\mathrm{cm}^{-1}\right)$ 2955, 2931, 1479, 1297, 1193. HRMS calcd. $\mathrm{C}_{21} \mathrm{H}_{31} \mathrm{O}_{3} \mathrm{Si}[\mathrm{M}+\mathrm{H}]^{+}: 359.2037$. Found: 359.2046.

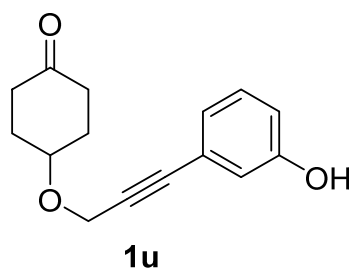

4-((3-(3-Hydroxyphenyl)prop-2-yn-1-yl)oxy)cyclohexan-1-one (1u): Synthesized from S1 and 3iodophenol by following general procedure A on a $4 \mathrm{mmol}$ scale. Yield $64 \%$. White solid. M.p. $70-72{ }^{\circ} \mathrm{C}$ $R_{f}=0.4$ (hexane/EtOAc = 1:1). ${ }^{1} \mathbf{H}$ NMR $\left(400 \mathrm{MHz}, \mathrm{CDCl}_{3}\right) \delta 7.18(\mathrm{td}, J=7.9,1.4 \mathrm{~Hz}, 1 \mathrm{H}), 7.01$ (ddt, $J$ = 7.6, 2.3, $1.1 \mathrm{~Hz}, 1 \mathrm{H}), 6.92(\mathrm{dt}, J=2.4,1.1 \mathrm{~Hz}, 1 \mathrm{H}), 6.83(\mathrm{ddt}, J=8.3,2.5,1.2 \mathrm{~Hz}, 1 \mathrm{H}), 5.82(\mathrm{br}, 1 \mathrm{H})$, $4.46(\mathrm{~s}, 2 \mathrm{H}), 4.03(\mathrm{tt}, J=5.7,3.0 \mathrm{~Hz}, 1 \mathrm{H}), 2.64(\mathrm{ddd}, J=15.5,10.4,5.8 \mathrm{~Hz}, 2 \mathrm{H}), 2.38-2.26(\mathrm{~m}, 2 \mathrm{H})$, 2.23 - 2.11 (m, 2H), 2.06 - 1.94 (m, 2H). ${ }^{13} \mathbf{C}$ NMR (101 MHz, $\left.\mathrm{CDCl}_{3}\right) \delta 212.10,155.62,129.66,124.21$, 123.59, 118.43, 116.16, 85.90, 85.07, 72.12, 56.54, 37.15, 30.41 IR (KBr, cm $\left.{ }^{-1}\right) 3293,2940,1703,1579$, 1445, 1063. HRMS calcd. $\mathrm{C}_{15} \mathrm{H}_{17} \mathrm{O}_{3}[\mathrm{M}+\mathrm{H}]^{+}: 245.1172$. Found: 243.1180

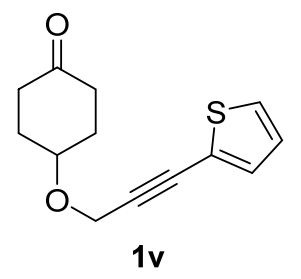


4-((3-(Thiophen-2-yl)prop-2-yn-1-yl)oxy)cyclohexan-1-one (1v): Synthesized from S1 and 2iodothiophene by following general procedure A on a $4 \mathrm{mmol}$ scale. Yield 53\%. Orange oil. $R_{f}=0.4$ (hexane/EtOAc = 3:1). ${ }^{1} \mathbf{H}$ NMR $\left(400 \mathrm{MHz}, \mathrm{CDCl}_{3}\right) \delta 7.29-7.26(\mathrm{~m}, 1 \mathrm{H}), 7.23(\mathrm{dd}, J=3.7,1.2 \mathrm{~Hz}, 1 \mathrm{H})$, $6.98(\mathrm{dd}, J=5.2,3.6 \mathrm{~Hz}, 1 \mathrm{H}), 4.48(\mathrm{~s}, 2 \mathrm{H}), 4.01(\mathrm{tt}, J=5.8,3.0 \mathrm{~Hz}, 1 \mathrm{H}), 2.69-2.54(\mathrm{~m}, 2 \mathrm{H}), 2.36-2.23$ $(\mathrm{m}, 2 \mathrm{H}), 2.22-2.09(\mathrm{~m}, 2 \mathrm{H}), 2.05-1.90(\mathrm{~m}, 1 \mathrm{H}) .{ }^{13} \mathbf{C}$ NMR $\left(101 \mathrm{MHz}, \mathrm{CDCl}_{3}\right) \delta 210.97,132.50,127.49$, 126.99, 122.38, 89.24, 79.40, 72.15, 56.57, 37.16, 30.41. IR (KBr, cm $\left.{ }^{-1}\right)$ 2956, 1710, 1275, 1261, 1061. HRMS calcd. $\mathrm{C}_{13} \mathrm{H}_{15} \mathrm{O}_{2} \mathrm{~S}[\mathrm{M}+\mathrm{H}]^{+}: 235.0787$. Found: 235.0792 .

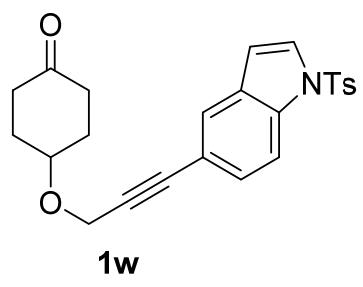

4-((3-(1-Tosyl-1H-indol-5-yl)prop-2-yn-1-yl)oxy)cyclohexan-1-one (1w): Synthesized from S1' and 5iodo-1-(4-methylphenylsulfonyl)indole following general procedure B on a $1 \mathrm{mmol}$ scale. Yield $62 \%$. Yellow solid. M.p. $76-78^{\circ} \mathrm{C} . R_{f}=0.4$ (hexane/EtOAc $\left.=2: 1\right) .{ }^{1} \mathbf{H}$ NMR $\left(400 \mathrm{MHz}, \mathrm{CDCl}_{3}\right) \delta 7.93(\mathrm{dd}, J$ $=8.6,0.9 \mathrm{~Hz}, 1 \mathrm{H}), 7.80-7.70(\mathrm{~m}, 2 \mathrm{H}), 7.66-7.61(\mathrm{~m}, 1 \mathrm{H}), 7.58(\mathrm{~d}, J=3.7 \mathrm{~Hz}, 1 \mathrm{H}), 7.38(\mathrm{dd}, J=8.6$, $1.6 \mathrm{~Hz}, 1 \mathrm{H}), 7.25-7.13(\mathrm{~m}, 2 \mathrm{H}), 6.62(\mathrm{dd}, J=3.7,0.8 \mathrm{~Hz}, 1 \mathrm{H}), 4.47(\mathrm{~s}, 2 \mathrm{H}), 4.03(\mathrm{tt}, J=5.7,3.0 \mathrm{~Hz}, 1 \mathrm{H})$, $2.63(\mathrm{ddd}, J=15.5,10.5,5.7 \mathrm{~Hz}, 2 \mathrm{H}), 2.35$ (s, 3H), 2.29 (dt, $J=14.6,5.8 \mathrm{~Hz}, 2 \mathrm{H}), 2.17$ (dq, $J=11.7,5.8$ $\mathrm{Hz}, 2 \mathrm{H}), 2.08-1.90$ (m, 2H). ${ }^{13} \mathbf{C}$ NMR (101 MHz, $\left.\mathrm{CDCl}_{3}\right) \delta 211.05,145.23,135.08,134.44,130.68$, 129.97, 128.10, 127.33, 126.81, 125.04, 117.44, 113.56, 108.73, 86.20, 84.37, 72.07, 56.55, 37.18, 30.45, 21.60. IR $\left(\mathrm{KBr}, \mathrm{cm}^{-1}\right) 3005,1711,1275,1261,1063$. HRMS calcd. $\mathrm{C}_{24} \mathrm{H}_{24} \mathrm{NO}_{4} \mathrm{~S}[\mathrm{M}+\mathrm{H}]^{+}: 422.1421$. Found: 422.1431.

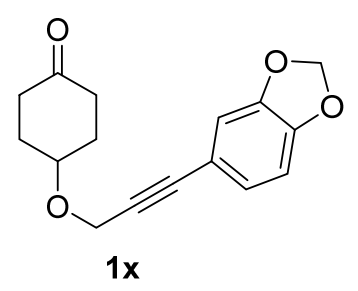

4-((3-(Benzo[d][1,3]dioxol-5-yl)prop-2-yn-1-yl)oxy)cyclohexan-1-one (1x): Synthesized from S1' and 5 -iodobenzo[d][1,3]dioxole following general procedure $B$ on a $2 \mathrm{mmol}$ scale. Yield $66 \%$. Yellow oil. $R_{f}$ $=0.45($ hexane/EtOAc $=3: 1) .{ }^{1} \mathbf{H}$ NMR $\left(400 \mathrm{MHz} \mathrm{CDCl}_{3}\right) \delta 6.97(\mathrm{dd}, J=8.0,1.6 \mathrm{~Hz}, 1 \mathrm{H}), 6.89(\mathrm{~d}, J=$ $1.6 \mathrm{~Hz}, 1 \mathrm{H}), 6.75(\mathrm{~d}, J=8.1 \mathrm{~Hz}, 1 \mathrm{H}), 5.97(\mathrm{~s}, 2 \mathrm{H}), 4.44(\mathrm{~s}, 2 \mathrm{H}), 4.01(\mathrm{dt}, J=5.6,2.7 \mathrm{~Hz}, 1 \mathrm{H}), 2.62$ (ddd, $J=15.5,10.5,5.7 \mathrm{~Hz}, 2 \mathrm{H}), 2.29(\mathrm{dt}, J=14.7,6.0 \mathrm{~Hz}, 2 \mathrm{H}), 2.21-2.09$ (m, 2H), 1.99 (dddd, $J=16.9,9.0$, 
4.4, 2.0 Hz, 2H). ${ }^{13} \mathrm{C}$ NMR (101 MHz, $\left.\mathrm{CDCl}_{3}\right) \delta 211.03,148.11,147.42,126.46,115.69,111.72,108.45$, 101.36, 85.95, 83.55, 72.05, 56.52, 37.18, 30.44. IR (KBr, cm $\left.{ }^{-1}\right)$ 2946, 1712, 1504, 1488, 1260. HRMS calcd. $\mathrm{C}_{16} \mathrm{H}_{17} \mathrm{O}_{4}[\mathrm{M}+\mathrm{H}]^{+}: 273.1121$. Found: 273.1131 .

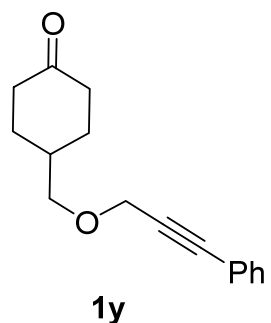

4-(((3-Phenylprop-2-yn-1-yl)oxy)methyl)cyclohexan-1-one (1y): Synthesized from S1y' and iodobenzene following general procedure $A$ on a $2 \mathrm{mmol}$ scale. Yield $45 \%$. Pale oil. $R_{f}=0.40$ (hexane/EtOAc = 3:1). ${ }^{1} \mathbf{H}$ NMR $\left(400 \mathrm{MHz}, \mathrm{CDCl}_{3}\right) \delta 7.50-7.40(\mathrm{~m}, 2 \mathrm{H}), 7.35$ - $7.28(\mathrm{~m}, 3 \mathrm{H}), 4.38(\mathrm{~s}$, 2H), $3.50(\mathrm{dd}, J=6.4,1.6 \mathrm{~Hz}, 2 \mathrm{H}), 2.51-2.26(\mathrm{~m}, 4 \mathrm{H}), 2.18-2.07(\mathrm{~m}, 3 \mathrm{H}), 1.62-1.39(\mathrm{~m}, 2 \mathrm{H}) .{ }^{13} \mathbf{C}$ NMR $\left(101 \mathrm{MHz}, \mathrm{CDCl}_{3}\right) \delta 211.76,131.74,128.51,128.33,122.56,86.22,85.11,73.97,59.18,40.43$, 36.39, 29.54. IR $\left(\mathrm{KBr}, \mathrm{cm}^{-1}\right) 2859,1714,1276,1260,1099$. HRMS calcd. $\mathrm{C}_{16} \mathrm{H}_{19} \mathrm{O}_{2}[\mathrm{M}+\mathrm{H}]^{+}: 243.1380$. Found: 243.1390.

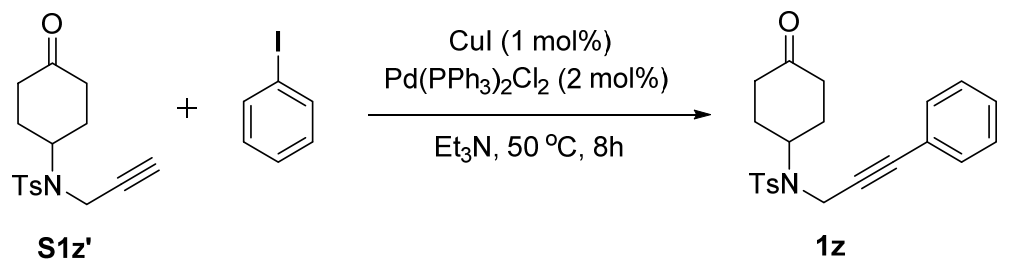

4-Methyl- $N$-(4-oxocyclohexyl)- $N$-(3-phenylprop-2-yn-1-yl)benzenesulfonamid (1z) : Synthesized from S1z' and iodobenzene by following general procedure B on a $3 \mathrm{mmol}$ scale. Yield 55\%. Brown solid. M.p. $73-75^{\circ} \mathrm{C} . R_{f}=0.40$ (hexane/EtOAc $\left.=3: 1\right) .{ }^{1} \mathbf{H}$ NMR $\left(400 \mathrm{MHz}, \mathrm{CDCl}_{3}\right) \delta 7.86(\mathrm{~d}, J=8.3 \mathrm{~Hz}$, 2H), 7.33 - $7.23(\mathrm{~m}, 5 \mathrm{H}), 7.19(\mathrm{dd}, J=8.0,1.7 \mathrm{~Hz}, 2 \mathrm{H}), 4.35(\mathrm{~s}, 2 \mathrm{H}), 4.34$ - $4.25(\mathrm{~m}, 1 \mathrm{H}), 2.46$ - $2.39(\mathrm{~m}$, 4H), 2.38 (s, 3H), 2.13 - 2.02 (m, 4H). ${ }^{13} \mathrm{C}$ NMR (101 MHz, $\left.\mathrm{CDCl}_{3}\right) \delta$ 208.63, 143.53, 137.78, 131.40, $129.65,128.57,128.28,127.36,122.24,84.88,84.71,55.68,40.03,33.38,30.19,21.52 . \mathbf{I R}\left(\mathrm{KBr}, \mathrm{cm}^{-1}\right)$ 2955, 1715, 1276, 1160, 1092. HRMS calcd. $\mathrm{C}_{22} \mathrm{H}_{24} \mathrm{NO}_{3} \mathrm{~S}[\mathrm{M}+\mathrm{H}]^{+}:$382.1471. Found: 382.1479.

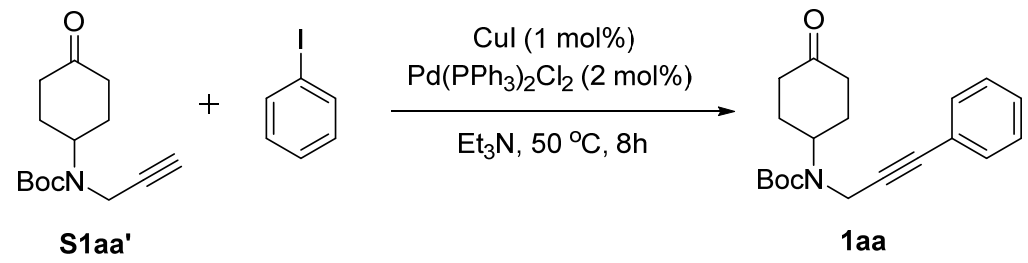


tert-Butyl (4-oxocyclohexyl)(3-phenylprop-2-yn-1-yl)carbamate (1aa): Synthesized from S1aa' and iodobenzene by following general procedure B on a 3 mmol scale. Yield $60 \%$. Pale solid. M.p. $62-64{ }^{\circ} \mathrm{C}$. $R_{f}=0.45$ (hexane/EtOAc = 3:1). ${ }^{1} \mathbf{H}$ NMR $\left(400 \mathrm{MHz}, \mathrm{CDCl}_{3}\right) \delta 7.41-7.33(\mathrm{~m}, 2 \mathrm{H}), 7.30(\mathrm{~m}, 3 \mathrm{H}), 4.45$ $(\mathrm{m}, 1 \mathrm{H}), 4.15(\mathrm{~s}, 2 \mathrm{H}), 2.51-2-.42(\mathrm{~m}, 4 \mathrm{H}), 2.28-1.97(\mathrm{~m}, 4 \mathrm{H}), 1.52(\mathrm{~s}, 9 \mathrm{H}) .{ }^{13} \mathbf{C} \mathbf{~ N M R}\left(101 \mathrm{MHz}, \mathrm{CDCl}_{3}\right)$ $\delta 209.69,154.83,131.52,128.33,128.29,122.86,86.48,80.66,65.87,40.14,33.25,29.82,28.47,15.30$. IR $\left(\mathrm{KBr}, \mathrm{cm}^{-1}\right) 3061,2971,1694,1489,1366,1269,1166$. HRMS calcd. $\mathrm{C}_{20} \mathrm{H}_{25} \mathrm{NNaO}_{3}[\mathrm{M}+\mathrm{Na}]^{+}$: 350.1727. Found: 350.1727.

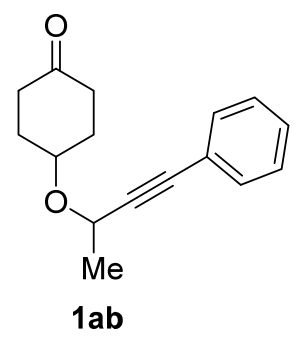

4-((4-Phenylbut-3-yn-2-yl)oxy)cyclohexan-1-one (1ab): Synthesized from S1ab' and iodobenzene following general procedure $A$ on a $2 \mathrm{mmol}$ scale. Yield 71\%. Yellow oil. $R_{f}=0.5$ (hexane/EtOAc $=3: 1$ ). ${ }^{1}$ H NMR (400 MHz, $\left.\mathrm{CDCl}_{3}\right) \delta 7.54$ - 7.41 (m, 2H), 7.35 - $7.29(\mathrm{~m}, 3 \mathrm{H}), 4.54$ (q, J=6.6 Hz, 1H), 4.13 (tt, $J=5.8,3.0 \mathrm{~Hz}, 1 \mathrm{H}), 2.75-2.47(\mathrm{~m}, 2 \mathrm{H}), 2.34-2.15(\mathrm{~m}, 4 \mathrm{H}), 2.14-1.92(\mathrm{~m}, 2 \mathrm{H}), 1.56(\mathrm{~d}, J=6.6 \mathrm{~Hz}$, $3 \mathrm{H}) .{ }^{13} \mathrm{C}$ NMR $\left(101 \mathrm{MHz}, \mathrm{CDCl}_{3}\right) \delta 211.36,131.68,128.42,128.33,122.62,89.38,84.66,71.05,63.42$, $37.49,37.23,31.89,29.89,22.81$. IR $\left(\mathrm{KBr}, \mathrm{cm}^{-1}\right) 2989,1717,1276,1261,1062$. HRMS calcd. $\mathrm{C}_{16} \mathrm{H}_{19} \mathrm{O}_{2}$ $[\mathrm{M}+\mathrm{H}]^{+}: 243.1380$. Found: 243.1390 .

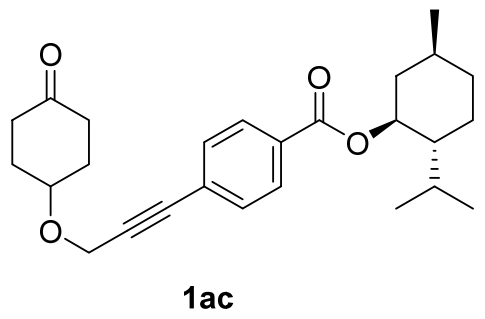

$(1 S, 2 R, 5 S)-2-I s o p r o p y l-5-m e t h y l c y c l o h e x 4-(3-((4-0 x o c y c l o h e x y l) o x y) p r o p-1-y n-1-y l) b e n z o a t e$ (1ac): Synthesized from $\mathbf{S 1}$ and (1S,2R,5S)-2-isopropyl-5-methylcyclohexyl 4-iodobenzoate following general procedure $A$ on a $2 \mathrm{mmol}$ scale. Yield $71 \%$. Yellow oil. $R_{f}=0.25$ (hexane/EtOAc $\left.=3: 1\right) .{ }^{1} \mathbf{H}$ NMR $(400$ $\left.\mathrm{MHz}, \mathrm{CDCl}_{3}\right) \delta 8.10(\mathrm{t}, J=1.8 \mathrm{~Hz}, 1 \mathrm{H}), 7.99(\mathrm{dt}, J=7.9,1.5 \mathrm{~Hz}, 1 \mathrm{H}), 7.60(\mathrm{dt}, J=7.7,1.5 \mathrm{~Hz}, 1 \mathrm{H}), 7.39$ (t, $J=7.8 \mathrm{~Hz}, 1 \mathrm{H}), 4.93(\mathrm{td}, J=10.9,4.4 \mathrm{~Hz}, 1 \mathrm{H}), 4.48(\mathrm{~s}, 2 \mathrm{H}), 4.03(\mathrm{tt}, J=5.7,3.0 \mathrm{~Hz}, 1 \mathrm{H}), 2.70-2.53$ (m, 2H), 2.35 - $2.24(\mathrm{~m}, 2 \mathrm{H}), 2.23-1.83(\mathrm{~m}, 6 \mathrm{H}), 1.78$ - $1.68(\mathrm{~m}, 2 \mathrm{H}), 1.62$ - $1.49(\mathrm{~m}, 2 \mathrm{H}), 1.16$ - $1.03(\mathrm{~m}$, 2H), $0.91(\mathrm{dd}, J=6.8,4.1 \mathrm{~Hz}, 7 \mathrm{H}), 0.78(\mathrm{~d}, J=7.0 \mathrm{~Hz}, 3 \mathrm{H}) .{ }^{13} \mathbf{C}$ NMR $\left(101 \mathrm{MHz}, \mathrm{CDCl}_{3}\right) \delta 210.91$, 
$165.28,135.67,132.80,131.16,129.58,128.45,122.83,86.10,85.18,75.20,72.21,56.43,47.23,40.94$, $37.15,34.28,31.45,30.41,26.47,23.56,22.05,20.80,16.46$. IR $\left(\mathrm{KBr}, \mathrm{cm}^{-1}\right) 2955,2878,1715,1261$, 1065. HRMS calcd. $\mathrm{C}_{26} \mathrm{H}_{35} \mathrm{O}_{4}[\mathrm{M}+\mathrm{H}]^{+}: 411.2530$. Found: 411.2522.

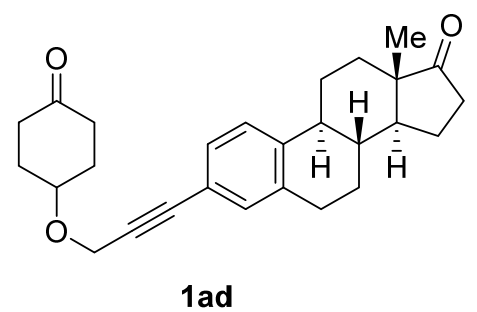

\section{$(8 R, 9 S, 13 S)-13-M e t h y l-3-(3-((4-0 x o c y c l o h e x y l) o x y) p r o p-1-y n-1-y l)-6,7,8,9,11,12,13,14,15,16-$}

decahydro-17H-cyclopenta[a]phenanthren-17-one (1ad): Synthesized from S1 and (8R,9S,13S,14S)-3iodo-13-methyl-6,7,8,9,11,12,13,14,15,16-decahydro-17H-cyclopenta[a]phenanthren-17-one following general procedure $A$ on a $2 \mathrm{mmol}$ scale. Yield $71 \%$. Yellow solid. M.p. $146-148{ }^{\circ} \mathrm{C} . \quad R_{f}=0.35$ (hexane/EtOAc = 3:1). ${ }^{1} \mathbf{H}$ NMR $\left(400 \mathrm{MHz}, \mathrm{CDCl}_{3}\right) \delta 7.25-7.12(\mathrm{~m}, 3 \mathrm{H}), 4.46(\mathrm{~s}, 2 \mathrm{H}), 4.03(\mathrm{tt}, J=5.8$, $3.0 \mathrm{~Hz}, 1 \mathrm{H}), 2.94-2.80(\mathrm{~m}, 2 \mathrm{H}), 2.70-2.58(\mathrm{~m}, 2 \mathrm{H}), 2.56-2.47(\mathrm{~m}, 1 \mathrm{H}), 2.45-2.36(\mathrm{~m}, 1 \mathrm{H}), 2.35-$ $2.25(\mathrm{~m}, 3 \mathrm{H}), 2.22-2.12(\mathrm{~m}, 3 \mathrm{H}), 2.10-1.93(\mathrm{~m}, 5 \mathrm{H}), 1.66-1.39(\mathrm{~m}, 7 \mathrm{H}), 0.91(\mathrm{~s}, 3 \mathrm{H}) .{ }^{13} \mathbf{C}$ NMR $(101$ $\left.\mathrm{MHz}, \mathrm{CDCl}_{3}\right) \delta 220.64,211.08,140.59,136.66,132.22,129.06,125.41,119.80,86.15,84.56,72.06$, $56.59,50.49,47.93,44.45,37.95,37.20,35.84,31.54,30.47,29.10,26.31,25.58,21.58,13.84$. IR (KBr, $\left.\mathrm{cm}^{-1}\right)$ 2932, 1737, 1275, 1261, 1045. HRMS calcd. $\mathrm{C}_{27} \mathrm{H}_{33} \mathrm{O}_{3}[\mathrm{M}+\mathrm{H}]^{+}:$405.2424. Found: 405.2430.

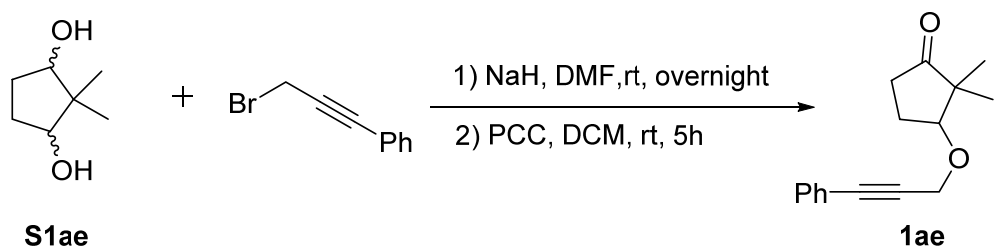

2,2-Dimethyl-3-((3-phenylprop-2-yn-1-yl)oxy)cyclopentan-1-one (1ae): $\mathrm{NaH}$ (17 mmol, $680 \mathrm{mg}) \mathrm{was}$ slowly added to the solution of S1ae $(12 \mathrm{mmol}, 1.5 \mathrm{~g})$ in DMF $(60 \mathrm{~mL})$ at $0{ }^{\circ} \mathrm{C}$. After stirring for 30 minutes, (3-bromoprop-1-yn-1-yl)benzene ( $24 \mathrm{mmol}, 4.5 \mathrm{~g}$ ) was added. The solution was allowed to slowly warm to room temperature. After stirring overnight, the reaction was quenched with statured aq. $\mathrm{NH}_{4} \mathrm{Cl}$ following by extraction with $\mathrm{Et}_{2} \mathrm{O} /$ EtOAc $(1: 1,60 \mathrm{~mL}$ x 3). The combined organics were dried over $\mathrm{MgSO}_{4}$, filtered and concentrated. Without further purification, the residue was dissolved in DCM $(25 \mathrm{~mL})$ in a $50 \mathrm{~mL}$ round bottom flask and stirred another $5 \mathrm{~h}$ at room temperature after PCC (10 mmol, $2.15 \mathrm{~g}$ ) was added. The reaction mixture was filtered through celite and eluted with DCM to remove the brown precipitate. The filtrate was concentrated under vacuo. Purification with column chromatography over silica gel (hexane:EtOAc $=5: 1)$ yielded the desired 1ae as a yellow oil. $7 \%(200 \mathrm{mg}) . R_{f}=0.5$ 
(hexane/EtOAc = 3:1). ${ }^{1} \mathbf{H}$ NMR $\left(400 \mathrm{MHz}, \mathrm{CDCl}_{3}\right) \delta 7.49-7.40(\mathrm{~m}, 2 \mathrm{H}), 7.32(\mathrm{dd}, J=5.1,2.0 \mathrm{~Hz}, 3 \mathrm{H})$, $4.45(\mathrm{~d}, J=3.3 \mathrm{~Hz}, 1 \mathrm{H}), 3.96(\mathrm{dd}, J=6.5,5.2 \mathrm{~Hz}, 1 \mathrm{H}), 2.57-2.36(\mathrm{~m}, 1 \mathrm{H}), 2.34-2.13$ (m, 2H), 2.11 $1.94(\mathrm{~m}, 1 \mathrm{H}), 1.11(\mathrm{~s}, 3 \mathrm{H}), 1.05$ (s, 3H). ${ }^{13} \mathbf{C}$ NMR $\left(101 \mathrm{MHz}, \mathrm{CDCl}_{3}\right) \delta 220.49,131.69,128.54,128.35$, $122.55,86.09,85.30,84.44,57.57,49.59,34.39,24.40,22.69,17.50$. IR $\left(\mathrm{KBr}, \mathrm{cm}^{-1}\right)$ 2969, 2231, 1739, 1490, 1171, 1083. HRMS calcd. $\mathrm{C}_{16} \mathrm{H}_{19} \mathrm{O}_{2}[\mathrm{M}+\mathrm{H}]^{+}: 243.1380$. Found: 243.1385.

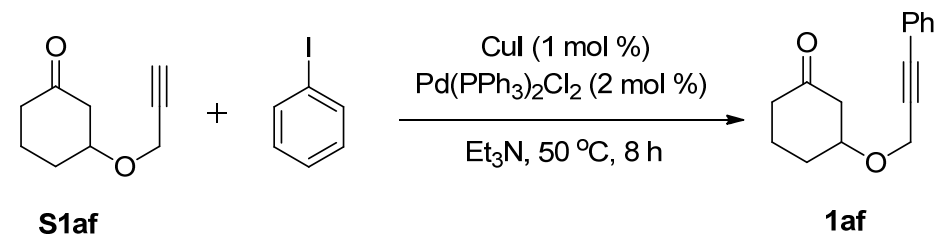

3-((3-Phenylprop-2-yn-1-yl)oxy)cyclohexan-1-one (1af): Synthesized from S1af and iodobenzene by following general procedure $A$ on a $1 \mathrm{mmol}$ scale. Yield $71 \%$. Colorless oil. $R_{f}=0.4$ (hexane/EtOAc $=$ 3:1). ${ }^{1}$ H NMR $\left(400 \mathrm{MHz}, \mathrm{CDCl}_{3}\right) \delta 7.53-7.38(\mathrm{~m}, 2 \mathrm{H}), 7.35-7.27(\mathrm{~m}, 2 \mathrm{H}), 4.40(\mathrm{~d}, J=1.9 \mathrm{~Hz}, 2 \mathrm{H})$, 4.10 (tdd, $J=7.1,4.2,2.8 \mathrm{~Hz}, 1 \mathrm{H}), 2.81-2.63$ (m, 1H), 2.53 (ddq, $J=14.3,7.2,0.9 \mathrm{~Hz}, 1 \mathrm{H}), 2.39-2.30$ $(\mathrm{m}, 2 \mathrm{H}), 2.15-1.99(\mathrm{~m}, 2 \mathrm{H}), 1.95-1.83(\mathrm{~m}, 1 \mathrm{H}), 1.78-1.65(\mathrm{~m}, 1 \mathrm{H}),{ }^{13} \mathbf{C} \mathbf{N M R}\left(101 \mathrm{MHz}, \mathrm{CDCl}_{3}\right) \delta$ 209.23, 131.77, 128.53, 128.31, 122.49, 86.17, 84.91, 75.57, 56.24, 47.29, 41.08, 29.81, 20.68. IR (KBr, $\left.\mathrm{cm}^{-1}\right)$ 2947, 2874, 1714, 1490, 1442, 1356. HRMS calcd. $\mathrm{C}_{15} \mathrm{H}_{17} \mathrm{O}_{2}[\mathrm{M}+\mathrm{H}]^{+}: 229.1223$. Found: 229.1215.

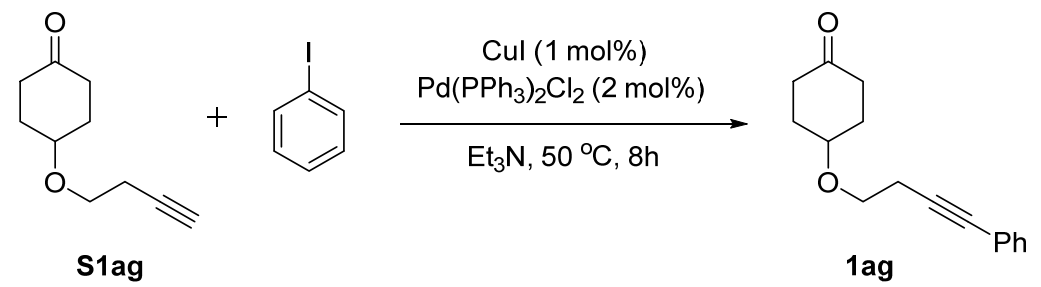

4-((4-Phenylbut-3-yn-1-yl)oxy)cyclohexan-1-one (1ag): Synthesized from $\mathbf{S 1 a g}^{9}$ and iodobenzene by following general procedure A on a $3 \mathrm{mmol}$ scale. Yield 91\%. Yellow oil. $R_{f}=0.4$ (hexane/EtOAc $=3: 1$ ). ${ }^{1} \mathbf{H}$ NMR $\left(400 \mathrm{MHz}, \mathrm{CDCl}_{3}\right) \delta 7.42-7.34(\mathrm{~m}, 2 \mathrm{H}), 7.31-7.26(\mathrm{~m}, 3 \mathrm{H}), 3.80(\mathrm{dt}, J=5.5,2.7 \mathrm{~Hz}, 1 \mathrm{H})$, $3.72(\mathrm{t}, \mathrm{J}=6.9 \mathrm{~Hz}, 2 \mathrm{H}), 2.72(\mathrm{t}, J=6.9 \mathrm{~Hz}, 2 \mathrm{H}), 2.69-2.58(\mathrm{~m}, 2 \mathrm{H}), 2.31-2.21(\mathrm{~m}, 2 \mathrm{H}), 2.14(\mathrm{ddt}, J=$ 13.3, 5.7, $1.5 \mathrm{~Hz}, 2 \mathrm{H}), 1.94(\mathrm{dddd}, J=14.8,10.8,5.2,2.9 \mathrm{~Hz}, 2 \mathrm{H}) .{ }^{13} \mathbf{C}$ NMR $\left(101 \mathrm{MHz}, \mathrm{CDCl}_{3}\right) \delta$ 211.32, 131.55, 128.27, 127.84, 123.53, 86.87, 81.53, 72.93, 66.80, 37.15, 30.59, 21.31. IR (KBr, $\left.\mathrm{cm}^{-1}\right)$ 2939, 2869, 1713, 1490, 1107, 758. HRMS calcd. $\mathrm{C}_{16} \mathrm{H}_{19} \mathrm{O}_{2}[\mathrm{M}+\mathrm{H}]^{+}, 243.1380$. Found: 243.1389. 


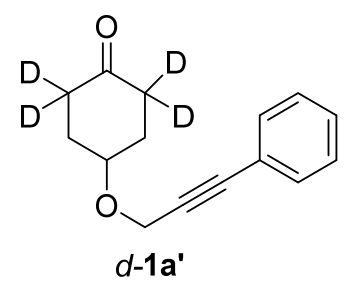

2,2,6,6- $d_{4}-4-((3-P h e n y l p r o p-2-y n-1-y l) o x y) c y c l o h e x a n-1-o n e ~\left(d-1 \mathbf{a}^{\prime}\right)$ : Synthesized by heating the mixture of $1 \mathrm{a}(33.6 \mathrm{mg}, 1.5 \mathrm{mmol})$ and $\mathrm{Na}_{2} \mathrm{CO}_{3}(80 \mathrm{mg}, 0.75 \mathrm{mmol})$ in $2 \mathrm{~mL}$ of $\mathrm{D}_{2} \mathrm{O}$ in a sealed vial at $110{ }^{\circ} \mathrm{C}$ for $12 \mathrm{~h}$. Yield 70\%. Yellow oil. $R_{f}=0.4$ (hexane/EtOAc $\left.=3: 1\right) .{ }^{1} \mathbf{H}$ NMR $\left(400 \mathrm{MHz}, \mathrm{CDCl}_{3}\right)$ $\delta 7.52-7.39(\mathrm{~m}, 2 \mathrm{H}), 7.34-7.29(\mathrm{~m}, 3 \mathrm{H}), 4.47(\mathrm{~s}, 2 \mathrm{H}), 4.03(\mathrm{tt}, J=5.7,3.0 \mathrm{~Hz}, 1 \mathrm{H}), 2.65-2.56(\mathrm{~m}$, $0.25 \mathrm{H}), 2.27(\mathrm{~d}, J=5.6 \mathrm{~Hz}, 0.26 \mathrm{H}), 2.16(\mathrm{dd}, J=13.5,5.4 \mathrm{~Hz}, 2 \mathrm{H}), 1.98(\mathrm{dt}, J=13.3,2.6 \mathrm{~Hz}, 2 \mathrm{H})$.

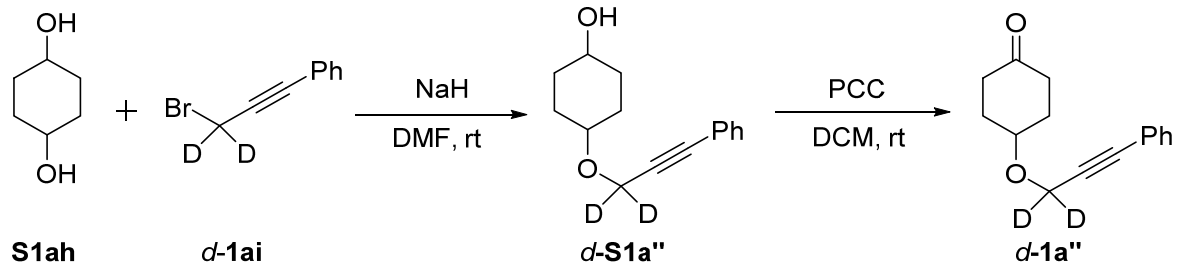

4-((3-Phenylprop-2-yn-1-yl-1,1-d 2$)$ oxy)cyclohexan-1-one (d-1a'’): $\mathrm{NaH}$ (7.5 mmol, $160 \mathrm{mg})$ was slowly added to the solution of S1ah $(10 \mathrm{mmol}, 550 \mathrm{mg})$ in DMF $(20 \mathrm{~mL})$ at room temperature. After stirring for 30 minutes, $d-\mathbf{1} \mathbf{a i}^{10}(5 \mathrm{mmol}, 490 \mathrm{mg}$ ) was added. After stirring overnight, the reaction was quenched with statured aq. $\mathrm{NH}_{4} \mathrm{Cl}$ following by extraction with $\mathrm{Et}_{2} \mathrm{O} /$ EtOAc $\left(1: 1,30 \mathrm{~mL}\right.$ x 3). The combined organics were dried over $\mathrm{MgSO}_{4}$, filtered and concentrated. Without further purification, the residue was dissolved in DCM (12 mL) in a 50 $\mathrm{mL}$ round bottom flask and stirred for another $5 \mathrm{~h}$ at room temperature after PCC (5 mmol, $1.1 \mathrm{~g})$ was added. The reaction mixture was filtered through celite and eluted with DCM to remove the brown precipitate. The filtrate was concentrated under vacuo. Purification with column chromatography over silica gel (hexane:EtOAc $=5: 1$ ) yielded the desired $d-1$ a' as a pale oil. $9 \%$ (100 mg). $R_{f}=0.4 .{ }^{1} \mathbf{H}$ NMR $\left(400 \mathrm{MHz}, \mathrm{CDCl}_{3}\right) \delta 7.48-7.41(\mathrm{~m}, 2 \mathrm{H}), 7.38$ - $7.29(\mathrm{~m}, 3 \mathrm{H}), 4.46(\mathrm{~d}$, $J=7.2 \mathrm{~Hz}, 0.49 \mathrm{H}), 4.04(\mathrm{tt}, J=5.7,3.0 \mathrm{~Hz}, 1 \mathrm{H}), 2.70-2.55(\mathrm{~m}, 2 \mathrm{H}), 2.38-2.25(\mathrm{~m}, 2 \mathrm{H}), 2.23$ $2.11(\mathrm{~m}, 2 \mathrm{H}), 2.07-1.91(\mathrm{~m}, 2 \mathrm{H})$. 


\section{Additional control experiments and optimization of the reaction conditions}

1、Additional selected control experiments and optimization of the reaction conditions for endo-2a.

\section{1) Ligand effect}

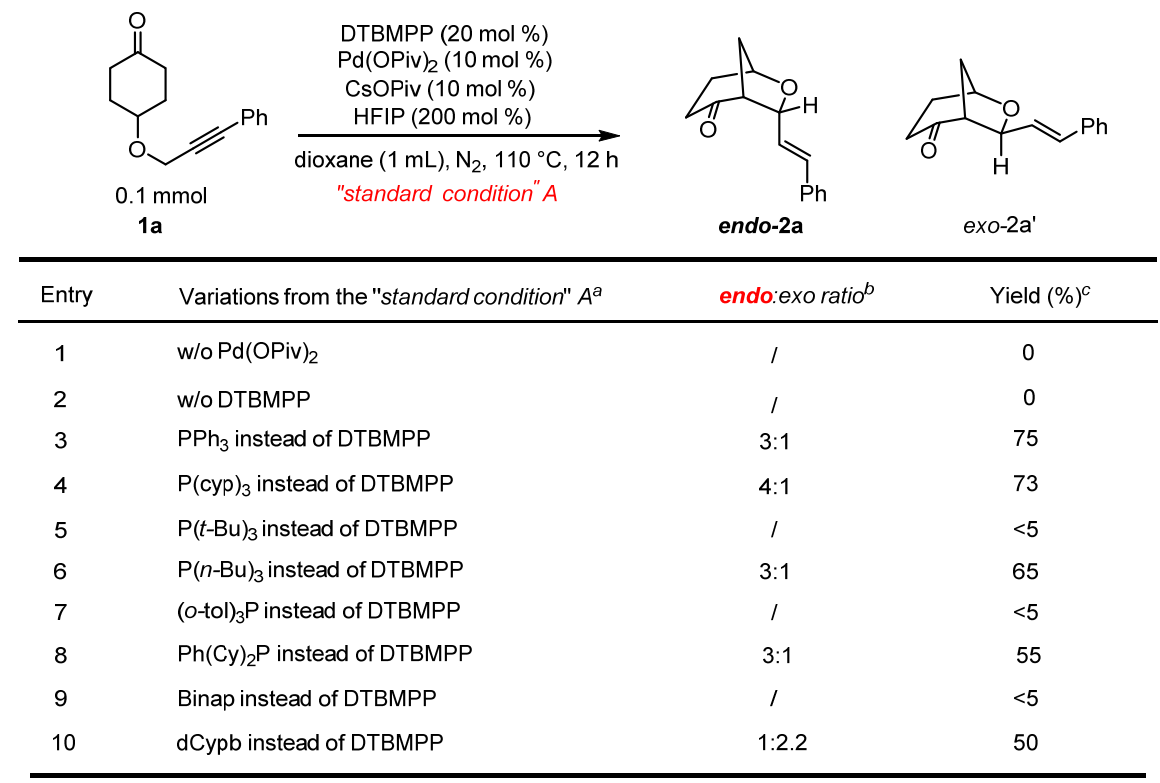

${ }^{a}$ Unless otherwise noted, all reactions were conducted with $1 \mathrm{a}\left(\mathrm{o.1 \textrm {mmol } )}\right.$ in dioxane $(1 \mathrm{~mL})$ at $110{ }^{\circ} \mathrm{C}$ for $12 \mathrm{~h}$.

${ }^{b}$ Determined by ${ }^{1} \mathrm{H}$ NMR analysis of the crude products. ${ }^{c}$ Yield determined by ${ }^{1} \mathrm{H}$ NMR analysis using 1,1,2,2tetrachloroethane as internal standard. 


\section{2) Base and acid additive effects}

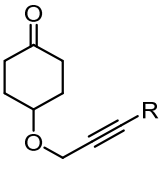

$0.1 \mathrm{mmol}$

$0.1 \mathrm{mmol}$

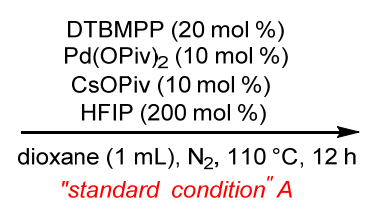

"standard condition" A

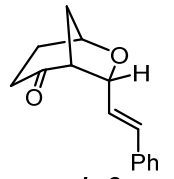

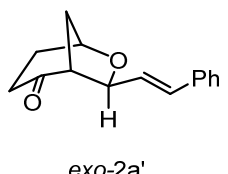

\begin{tabular}{|c|c|c|c|}
\hline Entry & Variations from the "standard conditions" $A^{a}$ & endo:exo ratio ${ }^{b}$ & Yield $(\%)^{C}$ \\
\hline 1 & $\mathrm{Cs}_{2} \mathrm{CO}_{3}$ & $5.5: 1$ & 79 \\
\hline 2 & NaOPiv & I & l \\
\hline 3 & KOPiv & I & I \\
\hline 4 & $\mathrm{~K}_{3} \mathrm{PO}_{4}$ & $6: 1$ & 80 \\
\hline 5 & $\mathrm{Et}_{3} \mathrm{~N}$ & l & I \\
\hline 6 & $t$-BuOK & $4: 1$ & 34 \\
\hline 7 & CsOPiv (20 mol\%) & $7: 1$ & 78 \\
\hline 8 & CsOPiv (50 mol\%) & $6.5: 1$ & 80 \\
\hline 9 & CsOPiv (150 mol\%) & $5.5: 1$ & 75 \\
\hline 10 & HFIP (1 equiv.) & $6.5: 1$ & 80 \\
\hline 11 & HFIP (5 equiv.) & $5.5: 1$ & 82 \\
\hline 12 & HFIP (10 equiv.) & $5: 1$ & 78 \\
\hline 13 & A1 instead of HFIP & $3: 1$ & 56 \\
\hline 14 & A2 instead of HFIP & I & I \\
\hline 15 & A3 instead of HFIP & $4: 1$ & 62 \\
\hline 16 & A1 instead of HFIP & I & I \\
\hline 17 & A2 instead of HFIP & $4: 1$ & 83 \\
\hline 18 & A3 instead of HFIP & $4.4: 1$ & 82 \\
\hline & $\mathrm{OOH}$ & $\mathrm{F}_{3} \mathrm{C}{\underset{\mathrm{Ph}}{\mathrm{OH}}}_{\mathrm{H}}^{\mathrm{H}}$ & $\mathfrak{H}^{\mathrm{OH}} \mathrm{CF}_{3}$ \\
\hline & $\mathrm{A} 2$ & A5 & A6 \\
\hline
\end{tabular}

${ }^{a}$ Unless otherwise noted, all reactions were conducted with $1 \mathrm{a}(0.1 \mathrm{mmol})$ in dioxane $(1 \mathrm{~mL})$ at $110{ }^{\circ} \mathrm{C}$ for $12 \mathrm{~h} .{ }^{b}$ Determined by ${ }^{1} \mathrm{H}$ NMR analysis of the crude products. ${ }^{c}$ Yield determined by ${ }^{1} \mathrm{H}$ NMR analysis using 1,1,2,2tetrachloroethane as internal standard. 


\section{3) Solvent and concentration effects}

\begin{tabular}{|c|c|c|c|c|}
\hline & nmol & $\begin{array}{l}\text { DTBMPP }(20 \mathrm{~mol} \%) \\
\text { Pd(OPiv })_{2}(10 \mathrm{~mol} \%) \\
\text { CsOPiv }(10 \mathrm{~mol} \%) \\
\operatorname{HFIP}(200 \mathrm{~mol} \%) \\
\text { dioxane }(1 \mathrm{~mL}), \mathrm{N}_{2}, 110^{\circ} \mathrm{C}, 12 \mathrm{~h} \\
\text { "standard condition" } \mathrm{A}\end{array}$ & endo-2a & $\begin{array}{c}\mathrm{H} \\
\text { exo-2a' }\end{array}$ \\
\hline Entry & \multicolumn{2}{|c|}{ Variations from the "standard condition" $A^{a}$} & endo:exo ratio ${ }^{b}$ & Yield $(\%)^{c}$ \\
\hline 1 & \multicolumn{2}{|c|}{ THF } & $6: 1$ & 46 \\
\hline 2 & \multicolumn{2}{|c|}{ toluene } & 3:1 & 32 \\
\hline 3 & \multicolumn{2}{|c|}{ ethyl acetate } & $5: 1$ & 40 \\
\hline 4 & \multicolumn{2}{|c|}{ benzene } & 4:1 & 36 \\
\hline 5 & \multicolumn{2}{|c|}{ DMF } & $4: 1$ & 30 \\
\hline 6 & \multicolumn{2}{|c|}{$\mathrm{CH}_{3} \mathrm{CN}$} & 9:1 & 23 \\
\hline 8 & \multicolumn{2}{|c|}{ dioxane $(0.5 \mathrm{~mL})$} & $5: 1$ & 65 \\
\hline 9 & \multicolumn{2}{|c|}{ dioxane $(2 \mathrm{~mL})$} & $5.2: 1$ & 78 \\
\hline
\end{tabular}

${ }^{a}$ Unless otherwise noted, all reactions were conducted with $1 \mathrm{a}(\mathrm{o} .1 \mathrm{mmol})$ in dioxane $(1 \mathrm{~mL})$ at $110{ }^{\circ} \mathrm{C}$ for $12 \mathrm{~h} .{ }^{b}$ Determined by ${ }^{1} \mathrm{H}$ NMR analysis of the crude products. ${ }^{c}$ Yield determined by ${ }^{1} \mathrm{H}$ NMR analysis using $1,1,2,2-$ tetrachloroethane as internal standard.

\section{4) Typical procedure for selected control experiments and optimization of reaction conditions for endo-2a.}

The reaction was conducted on a 0.1 mmol scale. A $4 \mathrm{~mL}$ vial was flame-dried and charged with $\mathrm{Pd}(\mathrm{OPiv})_{2}(3.06 \mathrm{mg}, 0.01 \mathrm{mmol})$ and DTBMPP $(13.8 \mathrm{mg}, 0.02 \mathrm{mmol})$. The vial was sealed with a black cap and transferred into a glove box. Inside the glovebox, 1,4-dioxane (distilled over $\mathrm{Na}, 1 \mathrm{~mL}$ ) was added and stirred for $10 \mathrm{~min}$. Then the ketone $1(0.1 \mathrm{mmol})$, CsOPiv $(2.34 \mathrm{mg}, 0.01 \mathrm{mmol})$ and HFIP (21 $\mathrm{uL}, 0.2 \mathrm{~mol}$ ) were added sequentially. After purged under $\mathrm{N}_{2}$ atmosphere for $5 \mathrm{~min}$, the vial was sealed with a black cap, transferred out of the glovebox and heated in a pie-block at $110{ }^{\circ} \mathrm{C}$. After $12 \mathrm{~h}$ (unless otherwise noted), the mixture was allowed to cool to room temperature.

For ${ }^{1} \mathrm{H}$-NMR analysis: After cooled to room temperature, the reaction mixture was filtered through a short plug of celite and eluted with DCM to remove the solid precipitate. The filtrate was then concentrated in vacuo. $\mathrm{CDCl}_{3}(1 \mathrm{~mL})$ and 1,1,2,2-tetrachloroethane (as the internal standard, about $25 \mathrm{mg}$ ) was added to the residue and the resulting mixture was directly used for ${ }^{1} \mathrm{H}-\mathrm{NMR}$ analysis. 
2、 Additional selected control experiments and optimization of the reaction conditions for the exo-2a'.

\section{1) Ligand effect}

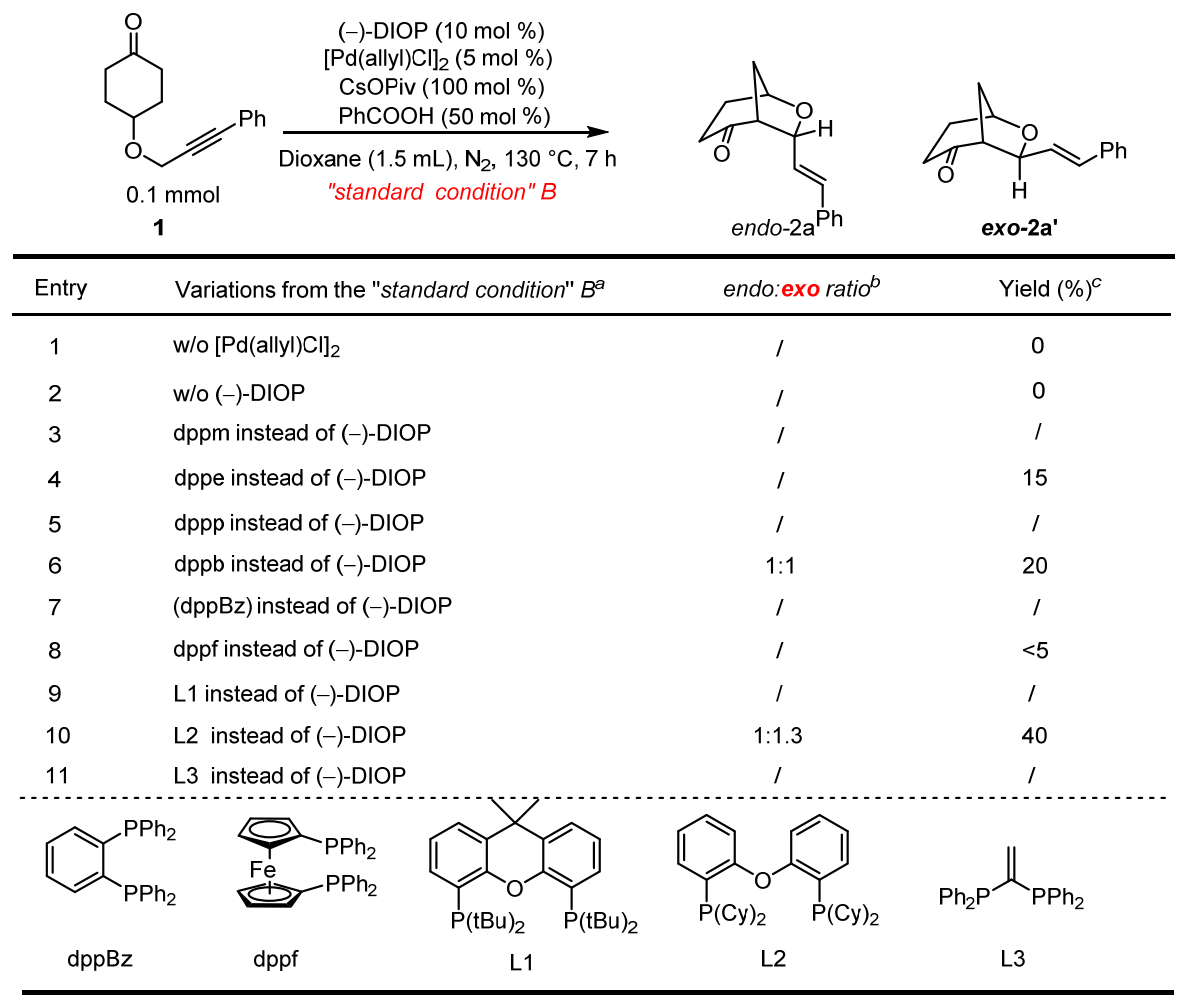

${ }^{a}$ Unless otherwise noted, all reactions were conducted with $1 \mathrm{a}\left(\mathrm{o.1 \textrm {mmol } )}\right.$ in dioxane $(\mathrm{m} \mathrm{mL})$ at $130{ }^{\circ} \mathrm{C}$ for $7 \mathrm{~h} .{ }^{b}$ Determined by ${ }^{1} \mathrm{H}$ NMR analysis of the crude products. ${ }^{c}$ Yield determined by ${ }^{1} \mathrm{H}$ NMR analysis using 1,1,2,2tetrachloroethane as internal standard.

\section{2) Pd precursor effect}

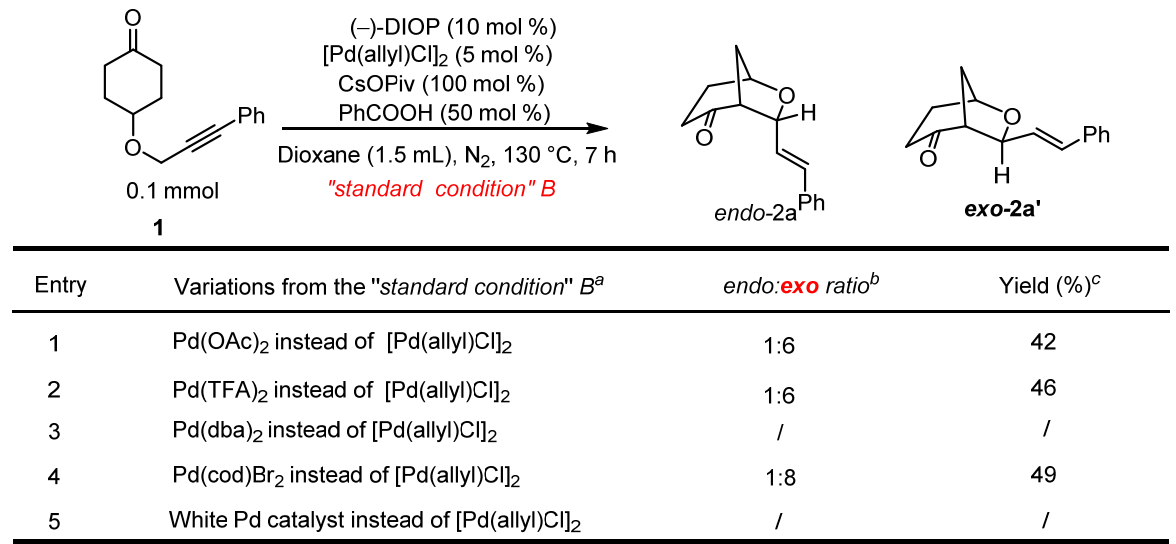

${ }^{a}$ Unless otherwise noted, all reactions were conducted with $1 \mathrm{a}(0.1 \mathrm{mmol})$ in dioxane $(1 \mathrm{~mL})$ at $130{ }^{\circ} \mathrm{C}$ for $7 \mathrm{~h} .{ }^{b}$ Determined by ${ }^{1} \mathrm{H}$ NMR analysis of the crude products. ${ }^{c}$ Yield determined by ${ }^{1} \mathrm{H}$ NMR analysis using 1,1,2,2tetrachloroethane as internal standard. 


\section{3) Base effect}

\begin{tabular}{|c|c|c|c|}
\hline & 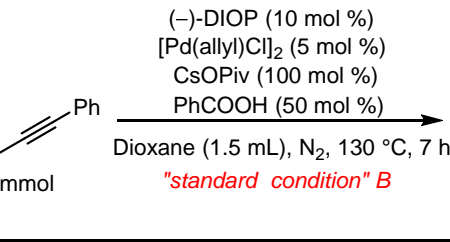 & $\prod_{\text {endo-2a }}$ & $\underbrace{O}_{\substack{H \\
\text { exo-2a' }}}$ \\
\hline Entry & Variations from the "standard condition" $B^{a}$ & endo:exo ratio ${ }^{b}$ & Yield $(\%)^{c}$ \\
\hline 1 & w/o CsOPiv & 1 & 1 \\
\hline 2 & NaOPiv instead of CsOPiv & I & $<5$ \\
\hline 3 & KOPiv instead of CsOPiv & I & $<5$ \\
\hline 4 & $\mathrm{~K}_{3} \mathrm{PO}_{4}$ instead of CsOPiv & 1 & l \\
\hline 5 & CsOAc instead of CsOPiv & 1 & 1 \\
\hline 6 & $\mathrm{Et}_{3} \mathrm{~N}$ instead of CsOPiv & 1 & 1 \\
\hline 7 & DBU instead of CsOPiv & 1 & 1 \\
\hline 8 & $\mathrm{KO}^{t} \mathrm{Bu}$ instead of CsOPiv & 1 & 1 \\
\hline 9 & CsOPiv (10 mol\%) & 1 & $<5$ \\
\hline 10 & CsOPiv (20 mol\%) & $1: 7$ & 52 \\
\hline 11 & CsOPiv (50 mol\%) & $1: 7$ & 60 \\
\hline 12 & CsOPiv (200 mol\%) & 1:11 & 67 \\
\hline
\end{tabular}

${ }^{a}$ Unless otherwise noted, all reactions were conducted with $1 \mathrm{a}(0.1 \mathrm{mmol})$ in dioxane $(1 \mathrm{~mL})$ at $130{ }^{\circ} \mathrm{C}$ for $7 \mathrm{~h} .{ }^{b}$ Determined by ${ }^{1} \mathrm{H}$ NMR analysis of the crude products. ${ }^{c}$ Yield determined by ${ }^{1} \mathrm{H}$ NMR analysis using 1,1,2,2tetrachloroethane as internal standard.

\section{4) Solvent and concentration effects}
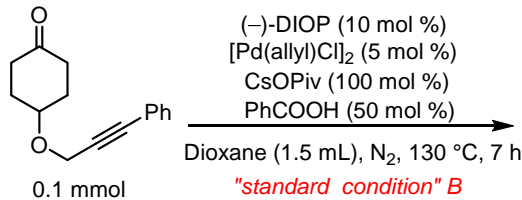

1
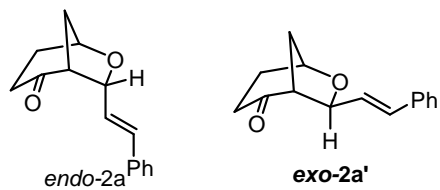

\begin{tabular}{c}
\hline Entry \\
\hline 1 \\
2 \\
3 \\
4 \\
5 \\
6 \\
7 \\
8 \\
9 \\
10 \\
11
\end{tabular}

Variations from the "sta

endo:exo ratio $\quad$ Yield $(\%)^{c}$

$\mathrm{PhCOOH}(100 \mathrm{~mol} \%) \quad 1: 9$

$\mathrm{PhCOOH}(25 \mathrm{~mol} \%)$

MeTHF instead of dioxane

THF instead of dioxane

EA instead of dioxane

DCE instead of dioxane

DMF instead of dioxane

Tolene instead of dioxane

Benzene instead of dioxane

Dioxane (1 $\mathrm{mL})$

Dioxane $(2 \mathrm{~mL})$

$\begin{array}{ll}1: 9 & 64 \\ 1: 7 & 60 \\ 1: 9 & 36 \\ 1: 9 & 32 \\ 1: 10 & 40 \\ / & / \\ / & / \\ 1: 9 & 34 \\ 1: 13 & 50 \\ 1: 12 & 62 \\ 1: 13 & 60\end{array}$

${ }^{a}$ Unless otherwise noted, all reactions were conducted with $1 \mathrm{a}(0.1 \mathrm{mmol})$ in dioxane $(1 \mathrm{~mL})$ at $130{ }^{\circ} \mathrm{C}$ for $7 \mathrm{~h} .{ }^{b}$ Determined by ${ }^{1} \mathrm{H}$ NMR analysis of the crude products. ${ }^{c}$ Yield determined by ${ }^{1} \mathrm{H}$ NMR analysis using 1,1,2,2tetrachloroethane as internal standard. 


\section{5) Typical procedure for selected control and optimization of reaction conditions for the exo-2a'.}

The reaction was conducted on a $0.1 \mathrm{mmol}$ scale. A $4 \mathrm{~mL}$ vial was flame-dried and charged with $[\mathrm{Pd}(\text { allyl }) \mathrm{Cl}]_{2}(1.8 \mathrm{mg}, 0.005 \mathrm{mmol})$ and (-)-DIOP $(4.9 \mathrm{mg}, 0.01 \mathrm{mmol})$. The vial was sealed and transferred into a glove box. Inside the glovebox, 1,4-dioxane (distilled over $\mathrm{Na}, 1.5 \mathrm{~mL}$ ) was added and stirred for $10 \mathrm{~min}$. Then the ketone $1(0.1 \mathrm{mmol})$, CsOPiv $(23.4 \mathrm{mg}, 0.1 \mathrm{mmol})$ and $\mathrm{PhCOOH}(6.1 \mathrm{mg}$, $0.1 \mathrm{mmol}$ ) were added sequentially. After purged under $\mathrm{N}_{2}$ atmosphere for $5 \mathrm{~min}$, the tube was sealed with a black cap, transferred out of the glovebox and heated in a pie-block at $130{ }^{\circ} \mathrm{C}$. After $7 \mathrm{~h}$ (unless otherwise noted), the mixture was allowed to cool to room temperature.

For ${ }^{1} H$-NMR analysis: After cooled to room temperature, the reaction mixture was filtered through a short plug of celite and eluted with DCM to remove the solid precipitate. The filtrate was then concentrated under vacuo. $\mathrm{CDCl}_{3}(1 \mathrm{~mL})$ and 1,1,2,2-tetrachloroethane (as the internal standard, about 25 $\mathrm{mg}$ ) were added to the residue and the resulting mixture was directly used for ${ }^{1} \mathrm{H}-\mathrm{NMR}$ analysis.

\section{Typical procedure for the substrate scope study}

1、 General procedure of "standard conditions A" : endo-2.
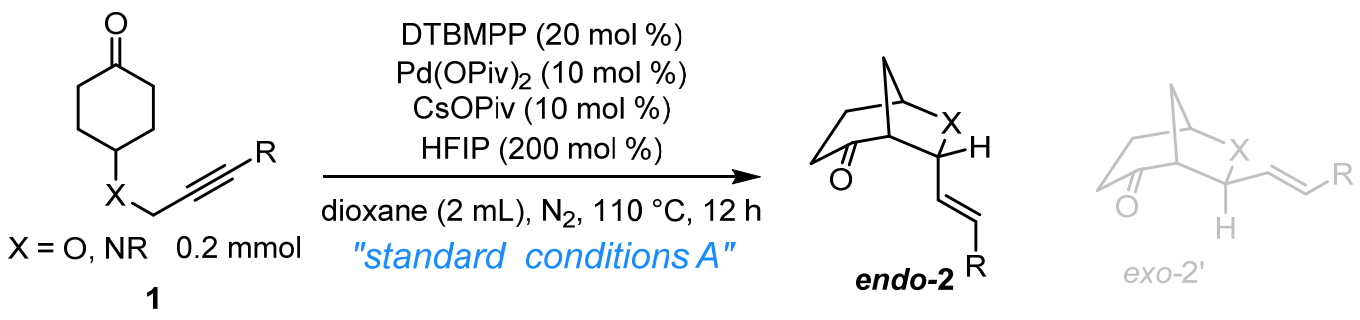

The reaction was conducted on a $0.2 \mathrm{mmol}$ scale. A $4 \mathrm{~mL}$ vial was flame-dried and charged with $\mathrm{Pd}(\mathrm{OPiv})_{2}(6.12 \mathrm{mg}, 0.02 \mathrm{mmol})$ and DTBMPP $(27.5 \mathrm{mg}, 0.04 \mathrm{mmol})$. The vial was sealed with a black cap and transferred into a glove box. Inside the glovebox, 1,4-dioxane (distilled over $\mathrm{Na}, 2 \mathrm{~mL}$ ) was added and the mixture was stirred for $10 \mathrm{~min}$. Then ketone 1 (0.2 mmol), CsOPiv (4.68 mg, $0.02 \mathrm{mmol})$ and HFIP (42 uL, $0.4 \mathrm{~mol}$ ) were added sequentially. After purged under $\mathrm{N}_{2}$ atmosphere for $5 \mathrm{~min}$, the vial was sealed with a black cap, transferred out of the glovebox and heated in a pie-block at $110{ }^{\circ} \mathrm{C}$. After 12 $\mathrm{h}$ (unless otherwise noted), the mixture was allowed to cool to room temperature.

For ${ }^{1} H$-NMR analysis of the endo:exo ratio: After cooled to room temperature, the reaction mixture was filtered through a short plug of Celite and eluted with DCM to remove the solid precipitate. The filtrate 
was then concentrated under vacuo. $\mathrm{CDCl}_{3}(1 \mathrm{~mL})$ was added to the residue and the resulting mixture was directly used for ${ }^{1} \mathrm{H}-\mathrm{NMR}$ analysis.

For pure compound isolation: After ${ }^{1} \mathrm{H}-\mathrm{NMR}$ analysis of the endo:exo ratio, carefully transfer the compound from the NMR tube to a $20 \mathrm{~mL}$ vial and wash NMR tube 3 times with DCM. The mixture was concentrated under vacuo and purified by column chromatography to give the desired product.

2、 General procedure of "standard conditions B" : exo-2'.
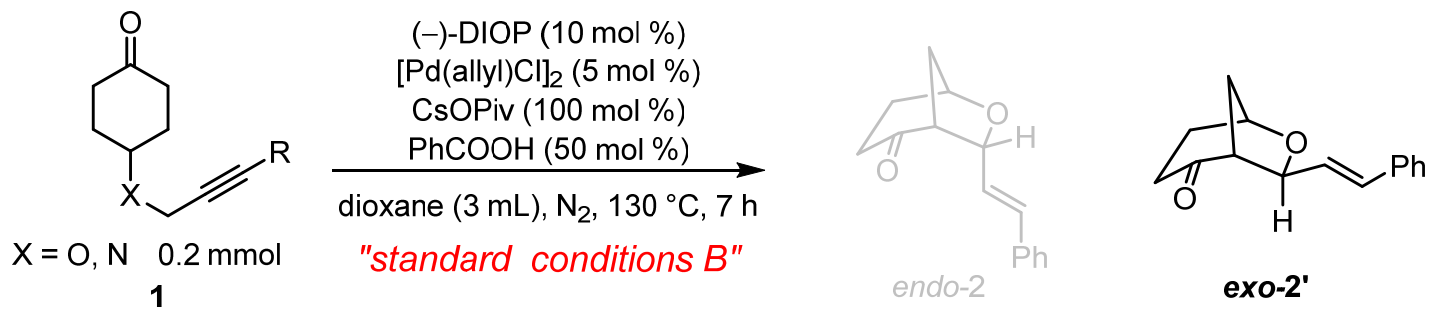

The reaction was conducted on a $0.2 \mathrm{mmol}$ scale. A $4 \mathrm{~mL}$ vial was flame-dried and charged with $[\mathrm{Pd}(\text { allyl }) \mathrm{Cl}]_{2}(3.6 \mathrm{mg}, 0.01 \mathrm{mmol})$ and (-)-DIOP $(9.8 \mathrm{mg}, 0.02 \mathrm{mmol})$. The vial was sealed with a black cap and transferred into a glove box. Inside the glovebox, 1,4-dioxane (distilled over $\mathrm{Na}, 3 \mathrm{~mL}$ ) was added and the mixture was stirred for $10 \mathrm{~min}$. Then, ketone 1 (0.2 mmol), CsOPiv (46.8 mg, $0.2 \mathrm{mmol})$ and $\mathrm{PhCOOH}$ (12.2 mg, $0.1 \mathrm{mmol}$ ) were added sequentially. After purged under $\mathrm{N}_{2}$ atmosphere for $5 \mathrm{~min}$, the tube was sealed with a black cap, transferred out of the glovebox and heated in a pie-block at $130{ }^{\circ} \mathrm{C}$. After $7 \mathrm{~h}$ (unless otherwise noted), the mixture was allowed to cool to room temperature. The mixture was diluted with DCM, passed through a small plug of silica gel and eluted with DCM. The solvent was removed in vacuo, and the residue was purified by column chromatography to give the desired product.

For ${ }^{1} \mathrm{H}$-NMR analysis of the endo:exo ratio: After cooled to room temperature, the reaction mixture was filtered through a short plug of celite and eluted with DCM to remove the solid precipitate. The filtrate was then concentrated under vacuo. $\mathrm{CDCl}_{3}(1 \mathrm{~mL})$ was added to the residue and the resulting mixture was directly used for ${ }^{1} \mathrm{H}-\mathrm{NMR}$ analysis.

For pure compound isolation: After ${ }^{1} \mathrm{H}-\mathrm{NMR}$ analysis of the endo:exo ratio, carefully transfer the compound from the NMR tube to a $20 \mathrm{~mL}$ vial and wash NMR tube 3 times with DCM. The solution then was concentrated under vacuo and purified by column chromatography to give the desired product. 


\section{Characterization data for the products}

$\underline{1 . \text { endo-2. }}$

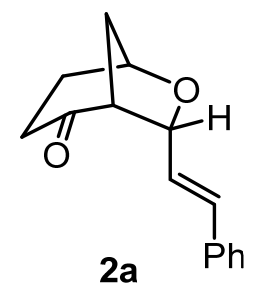

endo-7-((E)-3-((tert-Butyldimethylsilyl)oxy)styryl)-6-oxabicyclo[3.2.1]octan-2-one (2a): Synthesized from 1a according to "standard conditions A". The endo structure is determined by X-ray structure of the crystal as well as COSY and NOESY analysis (vide infra). 78\% yield; exo:endo $=1: 8 ;$ yellow solid; M.p. $104-106{ }^{\circ} \mathrm{C} ; \mathrm{R}_{f}=0.3$ (hexane/EtOAc $\left.=3: 1\right) .{ }^{1} \mathbf{H}$ NMR $\left(400 \mathrm{MHz}, \mathrm{CDCl}_{3}\right) \delta 7.35(\mathrm{~d}, J=7.2 \mathrm{~Hz}$, 2H), $7.30(\mathrm{t}, J=7.5 \mathrm{~Hz}, 2 \mathrm{H}), 7.26-7.21(\mathrm{~m}, 1 \mathrm{H}), 6.76(\mathrm{dd}, J=15.9,1.8 \mathrm{~Hz}, 1 \mathrm{H}), 6.18$ (dd, $J=15.9,5.2$ $\mathrm{Hz}, 1 \mathrm{H}), 4.80(\mathrm{~d}, J=3.9 \mathrm{~Hz}, 1 \mathrm{H}), 4.66(\mathrm{dd}, J=4.2,2.3 \mathrm{~Hz}, 1 \mathrm{H}), 3.01$ (t, $J=4.3 \mathrm{~Hz}, 1 \mathrm{H}), 2.57$ - 2.46 (m, $1 \mathrm{H}), 2.43(\mathrm{dd}, J=9.9,8.0 \mathrm{~Hz}, 2 \mathrm{H}), 2.21(\mathrm{ddd}, J=14.3,8.3,3.6 \mathrm{~Hz}, 1 \mathrm{H}), 2.09$ (d, $J=12.1 \mathrm{~Hz}, 1 \mathrm{H}), 1.79$ 1.66 (m, 1H). ${ }^{13} \mathbf{C}$ NMR (100 MHz, $\left.\mathrm{CDCl}_{3}\right) \delta 209.33,136.28,132.19,128.54,127.89,126.62,124.88$, 81.56, 74.87, 55.28, 36.11, 35.64, 31.45. IR $\left(\mathrm{KBr}, \mathrm{cm}^{-1}\right) 3005,1715,1275,1261,1065$. HRMS calcd $\mathrm{C}_{15} \mathrm{H}_{17} \mathrm{O}_{2}[\mathrm{M}+\mathrm{H}]^{+}: 229.1223$. Found: 229.1228 .

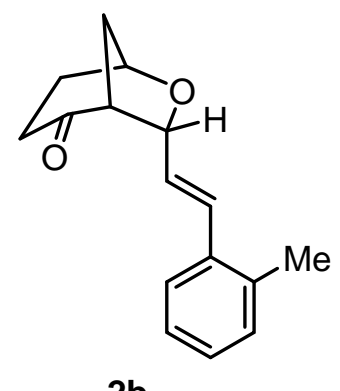

2b

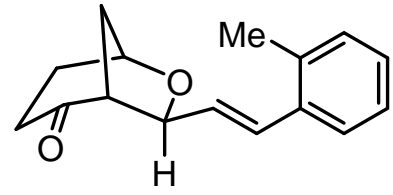

2b"

endo-7-((E)-2-Methylstyryl)-6-oxabicyclo[3.2.1]octan-2-one (2b): Synthesized from $1 \mathrm{~b}$ according to “standard conditions A". 58\% yield; exo:endo $=1: 3$. (exo-2b"): yellow oil; $\mathrm{R}_{f}=0.35$ (hexane/EtOAc $=$ 3:1). ${ }^{1} \mathbf{H}$ NMR $\left(400 \mathrm{MHz}, \mathrm{CDCl}_{3}\right) \delta 7.49-7.33(\mathrm{~m}, 1 \mathrm{H}), 7.22-7.08(\mathrm{~m}, 3 \mathrm{H}), 6.86(\mathrm{dd}, J=15.6,1.4 \mathrm{~Hz}$, $1 \mathrm{H}), 5.98(\mathrm{dd}, J=15.6,5.7 \mathrm{~Hz}, 1 \mathrm{H}), 4.80(\mathrm{dd}, J=5.7,1.4 \mathrm{~Hz}, 1 \mathrm{H}), 4.74-4.62(\mathrm{~m}, 1 \mathrm{H}), 2.82(\mathrm{~d}, J=4.9$ $\mathrm{Hz}, 1 \mathrm{H}), 2.64$ (ddd, $J=17.0,10.4,9.4 \mathrm{~Hz}, 1 \mathrm{H}), 2.47$ - $2.38(\mathrm{~m}, 2 \mathrm{H}), 2.34(\mathrm{~s}, 3 \mathrm{H}), 2.27$ - $2.18(\mathrm{~m}, 1 \mathrm{H})$, $1.95(\mathrm{~d}, J=12.3 \mathrm{~Hz}, 1 \mathrm{H}), 1.75$ (dddd, $J=13.7,10.5,7.8,1.6 \mathrm{~Hz}, 1 \mathrm{H}) .{ }^{13} \mathbf{C} \mathbf{~ N M R}\left(101 \mathrm{MHz}, \mathrm{CDCl}_{3}\right) \delta$ 210.17, 135.64, 135.47, 130.32, 129.81, 129.14, 127.76, 126.10, 125.76, 81.07, 75.12, 55.84, 34.67, 33.39, 32.11, 19.83. IR $\left(\mathrm{KBr}, \mathrm{cm}^{-1}\right) 3005,2988,1712,1461,1221,1072$. HRMS calcd $\mathrm{C}_{16} \mathrm{H}_{19} \mathrm{O}_{2}[\mathrm{M}+\mathrm{H}]^{+}$: 243.1380. Found: 243.1377. (endo-2b): yellow oil; $\mathrm{R}_{f}=0.30$ (hexane/EtOAc $\left.=3: 1\right) .{ }^{1} \mathbf{H}$ NMR (400 MHz, 
$\left.\mathrm{CDCl}_{3}\right) \delta 7.46-7.31(\mathrm{~m}, 1 \mathrm{H}), 7.20-7.08(\mathrm{~m}, 3 \mathrm{H}), 6.97(\mathrm{dd}, J=15.8,1.8 \mathrm{~Hz}, 1 \mathrm{H}), 6.05(\mathrm{dd}, J=15.8,5.1$ $\mathrm{Hz}, 1 \mathrm{H}), 4.82(\mathrm{ddd}, J=5.4,4.3,1.8 \mathrm{~Hz}, 1 \mathrm{H}), 4.66(\mathrm{ddd}, J=5.7,3.6,1.6 \mathrm{~Hz}, 1 \mathrm{H}), 3.02(\mathrm{td}, J=4.3,0.8 \mathrm{~Hz}$, $1 \mathrm{H}), 2.55-2.39(\mathrm{~m}, 3 \mathrm{H}), 2.33(\mathrm{~s}, 3 \mathrm{H}), 2.25-2.15(\mathrm{~m}, 1 \mathrm{H}), 2.10$ (d, $J=12.2 \mathrm{~Hz}, 1 \mathrm{H}), 1.72$ (dtd, $J=13.8$, 9.9, 9.4, $1.7 \mathrm{~Hz}, 1 \mathrm{H}) .{ }^{13} \mathbf{C}$ NMR $\left(100 \mathrm{MHz}, \mathrm{CDCl}_{3}\right) \delta$ 209.33, 135.61, 135.58, 130.20, 127.78, 126.47, $126.10,126.03,81.75,74.86,55.36,36.05,35.65,31.42,19.82$. IR $\left(\mathrm{KBr}, \mathrm{cm}^{-1}\right) 2949,1714,1385,1445$, 1270, 1221. HRMS calcd $\mathrm{C}_{16} \mathrm{H}_{19} \mathrm{O}_{2}[\mathrm{M}+\mathrm{H}]^{+}: 243.1380$. Found: 243.1380.

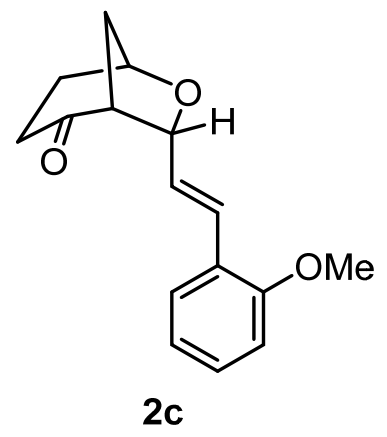

endo-7-((E)-2-Methoxystyryl)-6-oxabicyclo[3.2.1]octan-2-one (2c): Synthesized from 1c according to “standard conditions A". 63\% yield; exo:endo $=1: 5 ;$ yellow oil; $\mathrm{R}_{f}=0.3$ (hexane/EtOAc $=3: 1$ ). ${ }^{1} \mathbf{H}$ NMR $\left(400 \mathrm{MHz}, \mathrm{CDCl}_{3}\right) \delta 7.36(\mathrm{dd}, J=7.6,1.7 \mathrm{~Hz}, 1 \mathrm{H}), 7.21(\mathrm{ddd}, J=8.2,7.3,1.7 \mathrm{~Hz}, 1 \mathrm{H}), 7.06(\mathrm{dd}, J$ $=16.0,1.7 \mathrm{~Hz}, 1 \mathrm{H}), 6.89(\mathrm{td}, J=7.6,1.1 \mathrm{~Hz}, 1 \mathrm{H}), 6.85(\mathrm{dd}, J=8.2,1.0 \mathrm{~Hz}, 1 \mathrm{H}), 6.18(\mathrm{dd}, J=16.0,5.5$ $\mathrm{Hz}, 1 \mathrm{H}), 4.80$ (ddd, $J=5.7,4.1,1.7 \mathrm{~Hz}, 1 \mathrm{H}), 4.65$ (ddd, $J=5.6,3.6,1.5 \mathrm{~Hz}, 1 \mathrm{H}), 3.82$ (s, 3H), 2.99 (tt, $J$ $=4.3,1.0 \mathrm{~Hz}, 1 \mathrm{H}), 2.56-2.35(\mathrm{~m}, 3 \mathrm{H}), 2.27-2.16(\mathrm{~m}, 1 \mathrm{H}), 2.08(\mathrm{~d}, J=12.2 \mathrm{~Hz}, 1 \mathrm{H}), 1.70(\mathrm{dddd}, J=$ 13.8, 9.9, 8.3, $1.7 \mathrm{~Hz}, 1 \mathrm{H}) .{ }^{13} \mathbf{C}$ NMR $\left(100 \mathrm{MHz}, \mathrm{CDCl}_{3}\right) \delta 209.52,156.86,128.92,127.57,127.29$, $125.46,125.44,120.56,110.81,82.08,74.81,55.45,55.43,36.15,35.68,31.49$. IR $\left(\mathrm{KBr}, \mathrm{cm}^{-1}\right) 3005$, 1717, 1275, 1261, 1063. HRMS calcd $\mathrm{C}_{16} \mathrm{H}_{19} \mathrm{O}_{3}[\mathrm{M}+\mathrm{H}]^{+}:$259.1329. Found: 259.1339.

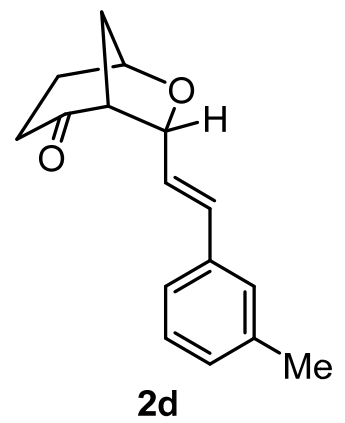

endo-7-((E)-3-Methylstyryl)-6-oxabicyclo[3.2.1]octan-2-one (2d): Synthesized from 1d according to “standard conditions A". $75 \%$ yield; exo:endo $=1: 4.8 ;$ pale oil; $\mathrm{R}_{f}=0.3$ (hexane/EtOAc $=3: 1$ ). ${ }^{1} \mathbf{H}$ NMR (400 MHz, $\left.\mathrm{CDCl}_{3}\right) \delta 7.29-7.11(\mathrm{~m}, 3 \mathrm{H}), 7.05$ (ddq, $\left.J=7.2,1.6,0.8 \mathrm{~Hz}, 1 \mathrm{H}\right), 6.73$ (dd, $J=15.9$, $1.8 \mathrm{~Hz}, 1 \mathrm{H}), 6.16(\mathrm{dd}, J=15.9,5.2 \mathrm{~Hz}, 1 \mathrm{H}), 4.79(\mathrm{ddd}, J=5.6,4.3,1.8 \mathrm{~Hz}, 1 \mathrm{H}), 4.65(\mathrm{ddd}, J=5.7,3.7$, 
$1.6 \mathrm{~Hz}, 1 \mathrm{H}), 3.00(\mathrm{t}, J=4.3 \mathrm{~Hz}, 1 \mathrm{H}), 2.53-2.37(\mathrm{~m}, 3 \mathrm{H}), 2.33(\mathrm{~s}, 3 \mathrm{H}), 2.25-2.15(\mathrm{~m}, 1 \mathrm{H}), 2.09(\mathrm{~d}, J=$ $12.1 \mathrm{~Hz}, 1 \mathrm{H}), 1.71$ (dddd, $J=13.8,9.9,8.5,1.6 \mathrm{~Hz}, 1 \mathrm{H}) .{ }^{13} \mathbf{C}$ NMR $\left(100 \mathrm{MHz}, \mathrm{CDCl}_{3}\right) \delta 209.37,138.11$, 136.22, 132.29, 128.68, 128.43, 127.27, 124.63, 123.84, 81.60, 74.84, 55.30, 36.12, 35.66, 31.47, 21.36. IR $\left(\mathrm{KBr}, \mathrm{cm}^{-1}\right) 2993,1714,1275,1254,1063$. HRMS calcd $\mathrm{C}_{16} \mathrm{H}_{19} \mathrm{O}_{2}[\mathrm{M}+\mathrm{H}]^{+}:$243.1380. Found: 243.1377 .

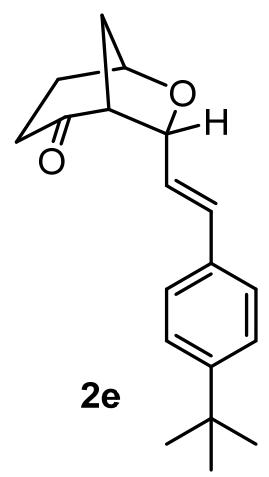

endo-7-((E)-4-(tert-Butyl)styryl)-6-oxabicyclo[3.2.1]octan-2-one (2e): Synthesized from 1f according to "standard conditions A". $80 \%$ yield; exo:endo $=1: 5$; pale oil; $\mathrm{R}_{f}=0.4$ (hexane/EtOAc $=3: 1$ ). ${ }^{1} \mathbf{H}$ NMR $\left(400 \mathrm{MHz}, \mathrm{CDCl}_{3}\right) \delta 7.38-7.26(\mathrm{~m}, 4 \mathrm{H}), 6.74(\mathrm{dd}, J=15.9,1.8 \mathrm{~Hz}, 1 \mathrm{H}), 6.14(\mathrm{dd}, J=15.9,5.1$ $\mathrm{Hz}, 1 \mathrm{H}), 4.80$ (ddd, $J=5.4,4.4,1.8 \mathrm{~Hz}, 1 \mathrm{H}), 4.65$ (ddd, $J=5.6,3.7,1.5 \mathrm{~Hz}, 1 \mathrm{H}), 3.00$ (t, $J=4.4 \mathrm{~Hz}, 1 \mathrm{H})$, 2.54 - 2.33 (m, 3H), 2.27 - 2.15 (m, 1H), 2.08 (d, $J=12.2 \mathrm{~Hz}, 1 \mathrm{H}), 1.70$ (dddd, $J=13.8,10.0,8.5,1.7 \mathrm{~Hz}$, 1H). ${ }^{13}$ C NMR (100 MHz, $\left.\mathrm{CDCl}_{3}\right) \delta 209.29,151.02,133.53,131.84,126.36,125.47,124.05,81.61$, 74.84, 55.30, 36.16, 35.66, 34.60, 31.51, 31.27. IR (KBr, cm $\left.{ }^{-1}\right)$ 2959, 1716, 1515, 1270, 1222, 1099. HRMS calcd $\mathrm{C}_{19} \mathrm{H}_{25} \mathrm{O}_{2}[\mathrm{M}+\mathrm{H}]^{+}:$285.1849. Found: 285.1859.

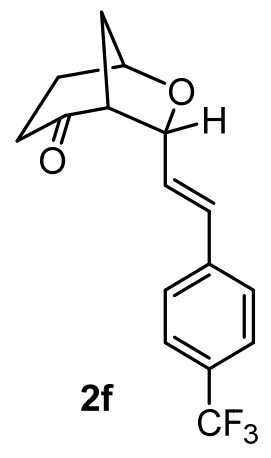

endo-7-((E)-4-(Trifluoromethyl)styryl)-6-oxabicyclo[3.2.1]octan-2-one (2f): Synthesized from $1 \mathrm{~g}$ according to "standard conditions A". $70 \%$ yield; exo:endo $=1: 4$; yellow solid; M.p. $120-122{ }^{\circ} \mathrm{C} ; \mathrm{R}_{f}=$ 0.30 (hexane/EtOAc = 3:1). ${ }^{1} \mathbf{H}$ NMR $\left(400 \mathrm{MHz} \mathrm{CDCl}_{3}\right) \delta 7.55(\mathrm{~d}, J=8.2 \mathrm{~Hz}, 2 \mathrm{H}), 7.44(\mathrm{~d}, J=8.1 \mathrm{~Hz}$, 2H), $6.80(\mathrm{dd}, J=15.9,1.8 \mathrm{~Hz}, 1 \mathrm{H}), 6.28(\mathrm{dd}, J=15.9,4.9 \mathrm{~Hz}, 1 \mathrm{H}), 4.81(\mathrm{td}, J=4.5,1.8 \mathrm{~Hz}, 1 \mathrm{H}), 4.68$ (ddd, $J=5.5,3.6,1.6 \mathrm{~Hz}, 1 \mathrm{H}), 3.03$ (t, $J=4.3 \mathrm{~Hz}, 1 \mathrm{H}), 2.50$ (dddd, $J=12.9,6.8,4.4,2.7 \mathrm{~Hz}, 1 \mathrm{H}), 2.45$ $2.30(\mathrm{~m}, 2 \mathrm{H}), 2.27-2.15(\mathrm{~m}, 1 \mathrm{H}), 2.11(\mathrm{~d}, J=12.2 \mathrm{~Hz}, 1 \mathrm{H}), 1.73(\mathrm{dtd}, J=13.9,9.1,1.7 \mathrm{~Hz}, 1 \mathrm{H}) .{ }^{13} \mathbf{C}$ 
NMR $\left(100 \mathrm{MHz}, \mathrm{CDCl}_{3}\right) \delta 209.06,139.73,130.53,129.83,129.51,127.84,126.76,125.53$ (q, $J=3.9$ Hz). 81.19, 74.99, 55.19, 35.95, 35.54, 31.28. IR (KBr, $\left.\mathrm{cm}^{-1}\right) 2956,1716,1325,1276,1067$. HRMS calcd $\mathrm{C}_{16} \mathrm{H}_{16} \mathrm{FO}_{2}[\mathrm{M}+\mathrm{H}]^{+}$: 297.1097.Found: 297.1098.

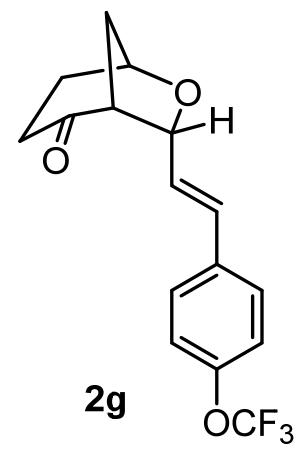

endo-7-((E)-4-(Trifluoromethoxy)styryl)-6-oxabicyclo[3.2.1]octan-2-one (2g): Synthesized from 1h according to "standard conditions $A$ ". $80 \%$ yield; exo:endo $=1: 6.3$; yellow oil; $\mathrm{R}_{f}=0.3$ (hexane $/ \mathrm{EtOAc}=$ 3:1). ${ }^{1} \mathbf{H}$ NMR $\left(400 \mathrm{MHz}, \mathrm{CDCl}_{3}\right) \delta 7.42$ - $7.32(\mathrm{~m}, 2 \mathrm{H}), 7.14(\mathrm{dt}, J=7.7,1.2 \mathrm{~Hz}, 2 \mathrm{H}), 6.75(\mathrm{dd}, J=15.9$, $1.8 \mathrm{~Hz}, 1 \mathrm{H}), 6.16(\mathrm{dd}, J=15.9,5.0 \mathrm{~Hz}, 1 \mathrm{H}), 4.79$ (td, $J=4.7,1.8 \mathrm{~Hz}, 1 \mathrm{H}), 4.66(\mathrm{ddd}, J=5.6,3.6,1.7 \mathrm{~Hz}$, $1 \mathrm{H}), 3.01(\mathrm{t}, J=4.3 \mathrm{~Hz}, 1 \mathrm{H}), 2.49$ (dddd, $J=14.1,11.6,7.1,5.0 \mathrm{~Hz}, 1 \mathrm{H}), 2.41(\mathrm{ddd}, J=9.3,5.8,3.5 \mathrm{~Hz}$, 2H), 2.21 (ddt, $J=13.8,7.2,3.3 \mathrm{~Hz}, 1 \mathrm{H}), 2.10$ (d, $J=12.2 \mathrm{~Hz}, 1 \mathrm{H}), 1.72$ (dtd, $J=13.8,9.1,1.7 \mathrm{~Hz}, 1 \mathrm{H}$ ). ${ }^{13}$ C NMR $\left(101 \mathrm{MHz}, \mathrm{CDCl}_{3}\right) \delta 209.18,148.70,135.04,130.53,127.86,126.12,121.06,120.44\left({ }^{1} J_{\mathrm{C}-\mathrm{F}}=\right.$ $256 \mathrm{~Hz}), 81.30,74.93,55.23,35.97,35.56,31.31 . \mathbf{I R}\left(\mathrm{KBr}, \mathrm{cm}^{-1}\right)$ 2959, 1716, 1514, 1363, 1222, 1099. HRMS calcd. $\mathrm{C}_{16} \mathrm{H}_{16} \mathrm{~F}_{3} \mathrm{O}_{2}[\mathrm{M}+\mathrm{H}]^{+}:$313.1046. Found: 313.1049 .

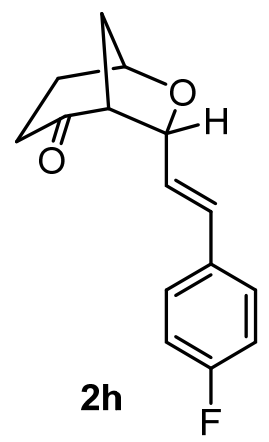

endo-7-((E)-4-Fluorostyryl)-6-oxabicyclo[3.2.1]octan-2-one (2h): Synthesized from 1i according to “standard conditions A”. $66 \%$ yield; exo:endo $=1: 3.1$; yellow oil; $\mathrm{R}_{f}=0.3$ (hexane/EtOAc $=3: 1$ ). ${ }^{1} \mathbf{H}$ NMR (400 MHz, $\left.\mathrm{CDCl}_{3}\right) \delta 7.40-7.27(\mathrm{~m}, 2 \mathrm{H}), 7.11-6.92(\mathrm{~m}, 2 \mathrm{H}), 6.72(\mathrm{dd}, J=15.9,1.7 \mathrm{~Hz}, 1 \mathrm{H}), 6.08$ (dd, $J=15.9,5.2 \mathrm{~Hz}, 1 \mathrm{H}), 4.77(\mathrm{ddd}, J=5.6,4.3,1.8 \mathrm{~Hz}, 1 \mathrm{H}), 4.66(\mathrm{ddd}, J=5.6,3.6,1.7 \mathrm{~Hz}, 1 \mathrm{H}), 3.00$ $(\mathrm{td}, J=4.3,0.9 \mathrm{~Hz}, 1 \mathrm{H}), 2.53-2.43(\mathrm{~m}, 2 \mathrm{H}), 2.27-2.14(\mathrm{~m}, 1 \mathrm{H}), 2.09(\mathrm{~d}, J=12.2 \mathrm{~Hz}, 1 \mathrm{H}), 1.72(\mathrm{dtd}, J=$ 13.8, 9.1, $1.7 \mathrm{~Hz}, 1 \mathrm{H}) .{ }^{13} \mathrm{C}$ NMR $\left(100 \mathrm{MHz}, \mathrm{CDCl}_{3}\right) \delta 209.32,162.48\left({ }^{1} J_{\mathrm{C}-\mathrm{F}}=247.3 \mathrm{~Hz}\right), 132.46,131.07$, $128.17\left({ }^{3} J_{\mathrm{C}-\mathrm{F}}=8.1 \mathrm{~Hz}\right) 124.66\left({ }^{4} J_{\mathrm{C}-\mathrm{F}}=2.3 \mathrm{~Hz}\right), 115.48\left({ }^{2} J_{\mathrm{C}-\mathrm{F}}=21.6 \mathrm{~Hz}\right) 81.50,74.87,55.27,36.02,35.60$, 
31.36. IR $\left(\mathrm{KBr}, \mathrm{cm}^{-1}\right)$ 3057, 2950, 1711, 1344, 1226, 1091. HRMS calcd. $\mathrm{C}_{15} \mathrm{H}_{16} \mathrm{FO}_{2}[\mathrm{M}+\mathrm{H}]^{+}: 247.1129$. Found: 247.1130 .

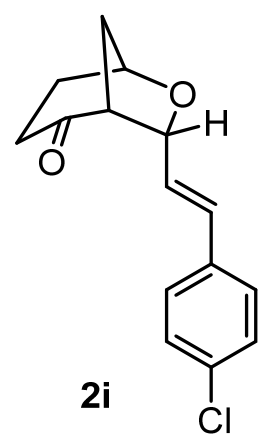

endo-7-((E)-4-Chlorostyryl)-6-oxabicyclo[3.2.1]octan-2-one (2i): Synthesized from $1 \mathbf{j}$ according to “standard conditions A”. $66 \%$ yield; exo:endo $=1: 3.6$; pale oil; $\mathrm{R}_{f}=0.25$ (hexane/EtOAc $\left.=3: 1\right) .{ }^{1} \mathbf{H}$ NMR $\left(400 \mathrm{MHz}, \mathrm{CDCl}_{3}\right) \delta 7.26(\mathrm{~d}, J=2.2 \mathrm{~Hz}, 4 \mathrm{H}), 6.71(\mathrm{dd}, J=15.9,1.8 \mathrm{~Hz}, 1 \mathrm{H}), 6.14(\mathrm{dd}, J=15.9$, $5.1 \mathrm{~Hz}, 1 \mathrm{H}), 4.77$ (ddd, $J=5.6,4.3,1.8 \mathrm{~Hz}, 1 \mathrm{H}), 4.65$ (ddd, $J=5.6,3.6,1.6 \mathrm{~Hz}, 1 \mathrm{H}), 3.00$ (t, $J=4.3 \mathrm{~Hz}$, 1H), 2.48 (dddd, $J=12.7,6.7,4.2,2.7 \mathrm{~Hz}, 1 \mathrm{H}), 2.45-2.36$ (m, 2H), 2.20 (ddd, $J=13.5,6.9,3.3 \mathrm{~Hz}, 1 \mathrm{H}$ ), $2.09(\mathrm{~d}, J=12.2 \mathrm{~Hz}, 1 \mathrm{H}), 1.71(\mathrm{dtd}, J=13.8,9.1,1.7 \mathrm{~Hz}, 1 \mathrm{H}) .{ }^{13} \mathbf{C} \mathbf{N M R}\left(100 \mathrm{MHz}, \mathrm{CDCl}_{3}\right) \delta 209.24$, $134.77,133.56,130.93,128.72,127.82,125.64,81.41,74.90,55.23,36.00,35.58,31.33$. IR $\left(\mathrm{KBr}, \mathrm{cm}^{-1}\right)$ 2949, 1716, 1459, 1089, 1065. HRMS calcd. $\mathrm{C}_{15} \mathrm{H}_{16} \mathrm{ClO}_{2}[\mathrm{M}+\mathrm{H}]^{+}: 263.0833$. Found: 263.0834.

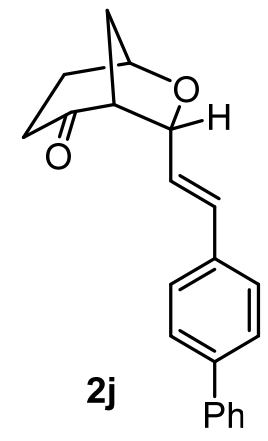

endo-7-((E)-2-([1,1'-Biphenyl]-4-yl)vinyl)-6-oxabicyclo[3.2.1]octan-2-one (2j): Synthesized from 1k according to "standard conditions A". $62 \%$ yield; exo:endo $=1: 2.4$; pale oil; $\mathrm{R}_{f}=0.3$ (hexane/EtOAc $=$ 3:1). ${ }^{1}$ H NMR (400 MHz, $\left.\mathrm{CDCl}_{3}\right) \delta 7.63-7.51(\mathrm{~m}, 4 \mathrm{H}), 7.47$ - $7.39(\mathrm{~m}, 4 \mathrm{H}), 7.37$ - $7.30(\mathrm{~m}, 1 \mathrm{H}), 6.81$ $(\mathrm{dd}, \mathrm{J}=15.9,1.8 \mathrm{~Hz}, 1 \mathrm{H}), 6.23(\mathrm{dd}, J=15.9,5.2 \mathrm{~Hz}, 1 \mathrm{H}), 4.82(\mathrm{ddd}, J=5.5,4.3,1.8 \mathrm{~Hz}, 1 \mathrm{H}), 4.67$ (ddd, $J=5.6,3.6,1.6 \mathrm{~Hz}, 1 \mathrm{H}), 3.02(\mathrm{t}, J=4.3 \mathrm{~Hz}, 1 \mathrm{H}), 2.56-2.37(\mathrm{~m}, 3 \mathrm{H}), 2.28-2.16(\mathrm{~m}, 1 \mathrm{H}), 2.10(\mathrm{~d}, J=$ $12.2 \mathrm{~Hz}, 1 \mathrm{H}), 1.72$ (dddd, $J=13.8,9.9,8.6,1.7 \mathrm{~Hz}, 1 \mathrm{H}) .{ }^{13} \mathbf{C} \mathbf{~ N M R}\left(100 \mathrm{MHz}, \mathrm{CDCl}_{3}\right) \delta 209.32,140.67$, 140.63 , 135.31, 131.70, 128.84, 128.79, 127.36, 127.25, 127.07, 126.99, 126.96, 124.99, 81.60, 74.89, 55.31, 36.11, 35.66, 31.45. IR $\left(\mathrm{KBr}, \mathrm{cm}^{-1}\right)$ 2950, 1714, 1486, 1221, 1072, 763. HRMS calcd $\mathrm{C}_{21} \mathrm{H}_{21} \mathrm{O}_{2}$ $[\mathrm{M}+\mathrm{H}]^{+}:$305.1536. Found: 305.1546 . 


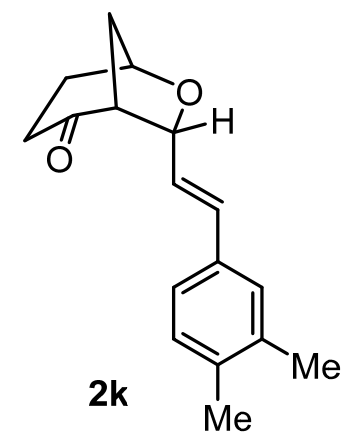

endo-7-((E)-3,4-Dimethylstyryl)-6-oxabicyclo[3.2.1]octan-2-one (2k): Synthesized from 11 according to "standard comdotion" A. 59\% yield; exo:endo = 1:5.3; yellow solid; M.p. $94-96{ }^{\circ} \mathrm{C} ; \mathrm{R}_{f}=0.3$ (hexane/EtOAc = 3:1). ${ }^{1} \mathbf{H}$ NMR $\left(400 \mathrm{MHz}, \mathrm{CDCl}_{3}\right) \delta 7.13(\mathrm{~d}, \mathrm{~J}=1.7 \mathrm{~Hz}, 1 \mathrm{H}), 7.11$ - $7.02(\mathrm{~m}, 2 \mathrm{H}), 6.70$ (dd, $J=15.9,1.7 \mathrm{~Hz}, 1 \mathrm{H}), 6.11(\mathrm{dd}, J=15.9,5.3 \mathrm{~Hz}, 1 \mathrm{H}), 4.78$ (ddd, $J=5.7,4.2,1.7 \mathrm{~Hz}, 1 \mathrm{H}), 4.65$ (ddd, $J=5.7,3.7,1.5 \mathrm{~Hz}, 1 \mathrm{H}), 2.99(\mathrm{t}, J=4.3 \mathrm{~Hz}, 1 \mathrm{H}), 2.53-2.36(\mathrm{~m}, 3 \mathrm{H}), 2.23(\mathrm{~s}, 6 \mathrm{H}), 2.19(\mathrm{~m}, 1 \mathrm{H}), 2.08(\mathrm{~d}$, $J=12.2 \mathrm{~Hz}, 1 \mathrm{H}), 1.70(\mathrm{dddd}, J=13.8,9.9,8.4,1.7 \mathrm{~Hz}, 1 \mathrm{H}) .{ }^{13} \mathbf{C} \mathbf{N M R}\left(100 \mathrm{MHz}, \mathrm{CDCl}_{3}\right) \delta 209.43$, $136.65,136.49,133.92$, 132.31, 129.79, 127.82, 124.16, 123.52, 81.73, 74.80, 55.31, 36.16, 35.68, 31.51, 19.74, 19.55. IR $\left(\mathrm{KBr}, \mathrm{cm}^{-1}\right) 2959,1716,1515,1363,1099,1072$. HRMS calcd. $\mathrm{C}_{17} \mathrm{H}_{21} \mathrm{O}_{2}$ $[\mathrm{M}+\mathrm{H}]^{+}: 257.1536$. Found: 257.1541 .

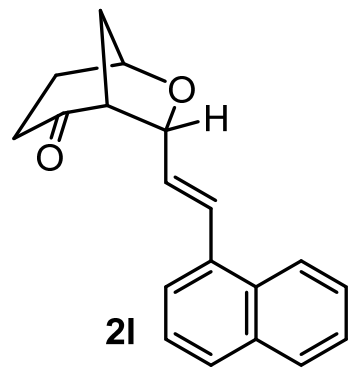

endo-7-((E)-2-(Naphthalen-1-yl)vinyl)-6-oxabicyclo[3.2.1]octan-2-one (2m): Synthesized from $1 \mathrm{~m}$ according to "standard conditions A". $68 \%$ yield; exo:endo $=1: 2$; yellow oil; $\mathrm{R}_{f}=0.35$ (hexane/EtOAc $=$ 3:1). ${ }^{1} \mathbf{H}$ NMR $\left(400 \mathrm{MHz}, \mathrm{CDCl}_{3}\right) \delta 8.19$ - $7.99(\mathrm{~m}, 1 \mathrm{H}), 7.84(\mathrm{dd}, J=8.0,1.6 \mathrm{~Hz}, 1 \mathrm{H}), 7.81-7.72(\mathrm{~m}$, $1 \mathrm{H}), 7.59-7.36(\mathrm{~m}, 5 \mathrm{H}), 6.23(\mathrm{dd}, J=15.7,4.9 \mathrm{~Hz}, 1 \mathrm{H}), 4.92(\mathrm{td}, J=4.6,1.8 \mathrm{~Hz}, 1 \mathrm{H}), 4.71$ (ddd, $J=5.6$, 3.6, $1.6 \mathrm{~Hz}, 1 \mathrm{H}), 3.09$ (td, $J=4.3,2.1 \mathrm{~Hz}, 1 \mathrm{H}), 2.60-2.37$ (m, 3H), $2.30-2.20$ (m, 1H), 2.14 (d, $J=12.2$ $\mathrm{Hz}, 1 \mathrm{H}), 1.75$ (dddd, $J=13.8,9.8,8.5,1.7 \mathrm{~Hz}, 1 \mathrm{H}) .{ }^{13} \mathbf{C}$ NMR $\left(101 \mathrm{MHz}, \mathrm{CDCl}_{3}\right) \delta 209.43,134.20$, $133.54,131.14,129.39,128.50,128.37,128.23,126.15,125.81,125.59,124.19,123.78,81.67,74.95$, 55.35, 36.02, 35.65, 31.41. IR (KBr, cm $\left.{ }^{-1}\right) 2962,2870,1716,1409,1226,1149$. HRMS calcd. $\mathrm{C}_{19} \mathrm{H}_{19} \mathrm{O}_{2}$ $[\mathrm{M}+\mathrm{H}]^{+}: 279.1380$. Found: 279.1384 . 


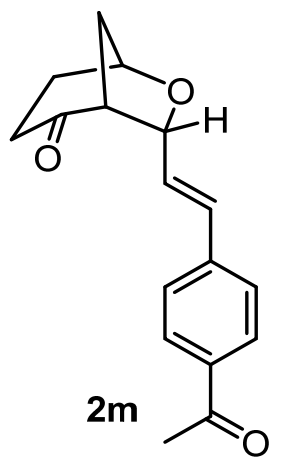

endo-7-((E)-4-Acetylstyryl)-6-oxabicyclo[3.2.1]octan-2-one (2m): Synthesized from 1n according to “standard conditions A”. 70\% yield; exo:endo $=1: 5.4 ;$ pale oil; $\mathrm{R}_{f}=0.3$ (hexane/EtOAc $=3: 1$ ). ${ }^{1} \mathbf{H}$ NMR (400 MHz, $\left.\mathrm{CDCl}_{3}\right) \delta 8.03-7.80(\mathrm{~m}, 2 \mathrm{H}), 7.57$ - $7.35(\mathrm{~m}, 2 \mathrm{H}), 6.81(\mathrm{dd}, J=15.9,1.8 \mathrm{~Hz}, 1 \mathrm{H}), 6.31$ $(\mathrm{dd}, J=15.9,4.9 \mathrm{~Hz}, 1 \mathrm{H}), 4.81(\mathrm{td}, J=4.6,1.8 \mathrm{~Hz}, 1 \mathrm{H}), 4.67(\mathrm{ddd}, J=5.6,3.7,1.7 \mathrm{~Hz}, 1 \mathrm{H}), 3.03(\mathrm{td}, J=$ 4.3, $1.0 \mathrm{~Hz}, 1 \mathrm{H}), 2.58(\mathrm{~s}, 3 \mathrm{H}), 2.50$ (dddd, $J=12.8,6.6,3.8,2.2 \mathrm{~Hz}, 1 \mathrm{H}), 2.44-2.37(\mathrm{~m}, 2 \mathrm{H}), 2.21$ (ddd, $J=14.0,7.8,3.3 \mathrm{~Hz}, 1 \mathrm{H}), 2.11(\mathrm{~d}, J=12.2 \mathrm{~Hz}, 1 \mathrm{H}), 1.80-1.66(\mathrm{~m}, 1 \mathrm{H}) .{ }^{13} \mathbf{C} \mathbf{N M R}\left(100 \mathrm{MHz}, \mathrm{CDCl}_{3}\right) \delta$ 209.08, 197.50, 140.86, 136.28, 130.89, 128.73, 128.05, 126.69, 81.29, 74.99, 55.21, 35.99, 35.56, 31.31, 26.62. IR $\left(\mathrm{KBr}, \mathrm{cm}^{-1}\right) 2951,1714,1679,1603,1269$, 1097. HRMS calcd. $\mathrm{C}_{17} \mathrm{H}_{19} \mathrm{O}_{3}[\mathrm{M}+\mathrm{H}]^{+}: 271.1329$. Found: 271.1337.

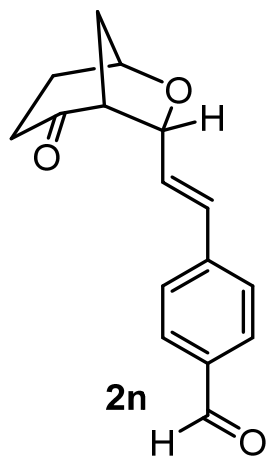

endo-4-((E)-2-Oxo-6-oxabicyclo[3.2.1]octan-7-yl)vinyl)benzaldehyde (2n): Synthesized from 10 according to "standard conditions A". $62 \%$ yield; exo:endo $=1: 5.2 ;$ pale oil; $\mathrm{R}_{f}=0.3$ (hexane/EtOAc $=$ 3:1). ${ }^{1}$ H NMR (400 MHz, $\left.\mathrm{CDCl}_{3}\right) \delta 9.97(\mathrm{~s}, 1 \mathrm{H}), 7.89-7.73(\mathrm{~m}, 2 \mathrm{H}), 7.61-7.42(\mathrm{~m}, 2 \mathrm{H}), 6.83(\mathrm{dd}, J=$ 15.9, $1.9 \mathrm{~Hz}, 1 \mathrm{H}), 6.35(\mathrm{dd}, J=15.9,4.8 \mathrm{~Hz}, 1 \mathrm{H}), 4.82(\mathrm{td}, J=4.5,1.9 \mathrm{~Hz}, 1 \mathrm{H}), 4.68$ (ddd, $J=5.6,3.6$, $1.7 \mathrm{~Hz}, 1 \mathrm{H}), 3.04$ (t, J=4.3 Hz, 1H), $2.56-2.46$ (m, 1H), $2.44-2.32$ (m, 2H), $2.26-2.17$ (m, 1H), 2.12 $(\mathrm{d}, J=12.2 \mathrm{~Hz}, 1 \mathrm{H}), 1.83-1.65(\mathrm{~m}, 1 \mathrm{H}) .{ }^{13} \mathbf{C} \mathbf{~ N M R}\left(100 \mathrm{MHz}, \mathrm{CDCl}_{3}\right) \delta$ 209.04, $191.66,142.25,135.62$, $130.73,130.11,128.88,127.11,81.21,75.03,55.20,35.94,35.54,31.26 . \mathbf{I R}\left(\mathrm{KBr}, \mathrm{cm}^{-1}\right) 3005,2989$, 1679, 1603, 1269, 1097. HRMS calcd. $\mathrm{C}_{16} \mathrm{H}_{17} \mathrm{O}_{3}[\mathrm{M}+\mathrm{H}]^{+}: 257.1172$. Found: 257.117 


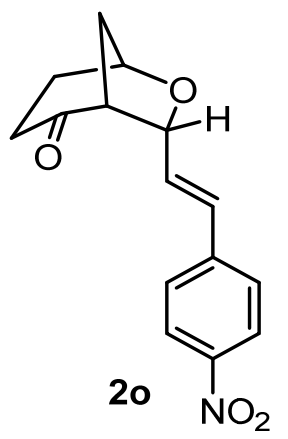

endo-7-((E)-4-Nitrostyryl)-6-oxabicyclo[3.2.1]octan-2-one (2o): Synthesized from 1p according to “standard conditions A". 62\% yield; exo:endo $=1: 3.4 ;$ yellow oil; $\mathrm{R}_{f}=0.15$ (hexane/EtOAc $\left.=3: 1\right) .{ }^{1} \mathbf{H}$ NMR $\left(400 \mathrm{MHz}, \mathrm{CDCl}_{3}\right) \delta 8.16(\mathrm{~d}, J=8.8 \mathrm{~Hz}, 2 \mathrm{H}), 7.47(\mathrm{~d}, J=8.7 \mathrm{~Hz}, 2 \mathrm{H}), 6.84(\mathrm{dd}, J=15.9,1.9 \mathrm{~Hz}$, 1H), 6.37 (dd, $J=15.9,4.6 \mathrm{~Hz}, 1 \mathrm{H}), 4.82(\mathrm{td}, J=4.4,1.9 \mathrm{~Hz}, 1 \mathrm{H}), 4.69$ (ddd, $J=5.6,3.5,1.7 \mathrm{~Hz}, 1 \mathrm{H})$, 3.05 (tt, $J=4.4,1.0 \mathrm{~Hz}, 1 \mathrm{H}), 2.56-2.46(\mathrm{~m}, 1 \mathrm{H}), 2.46-2.29(\mathrm{~m}, 2 \mathrm{H}), 2.26-2.15(\mathrm{~m}, 1 \mathrm{H}), 2.13(\mathrm{~d}, J=$ $12.2 \mathrm{~Hz}, 1 \mathrm{H}), 1.82$ - $1.67(\mathrm{~m}, 1 \mathrm{H}) .{ }^{13} \mathrm{C} \mathbf{N M R}\left(100 \mathrm{MHz}, \mathrm{CDCl}_{3}\right) \delta$ 208.93, 147.13, 142.66, 130.19, 129.65, 127.15, 124.01, 81.03, 75.09, 55.15, 35.85, 35.49, 31.17. IR (KBr, cm $\left.{ }^{-1}\right) 2952,1712,1596,1515$, 1343, 1109. HRMS calcd $\mathrm{C}_{15} \mathrm{H}_{16} \mathrm{NO}_{4}[\mathrm{M}+\mathrm{H}]^{+}: 274.1074$. Found: 274.1082 .

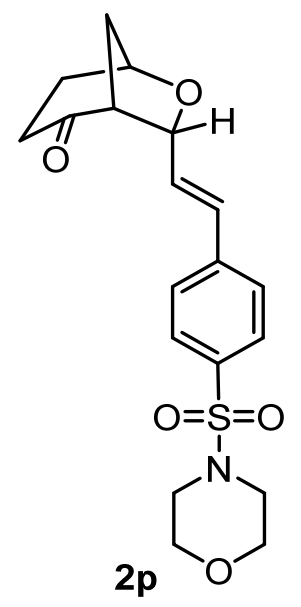

endo-7-((E)-4-(Morpholinosulfonyl)styryl)-6-oxabicyclo[3.2.1]octan-2-one (2p): Synthesized from 1q according to "standard conditions A". $55 \%$ yield; exo:endo $=1: 2.3 ;$ yellow oil; $\mathrm{R}_{f}=0.15$ (hexane/EtOAc = 1:1). ${ }^{1} \mathbf{H}$ NMR $\left(400 \mathrm{MHz}, \mathrm{CDCl}_{3}\right) \delta 7.94-7.60(\mathrm{~m}, 2 \mathrm{H}), 7.50(\mathrm{~d}, J=8.4 \mathrm{~Hz}, 2 \mathrm{H}), 6.82$ (dd, $J=16.0,1.9 \mathrm{~Hz}, 1 \mathrm{H}), 6.34(\mathrm{dd}, J=16.0,4.6 \mathrm{~Hz}, 1 \mathrm{H}), 4.83(\mathrm{td}, J=4.5,1.9 \mathrm{~Hz}, 1 \mathrm{H}), 4.69$ (ddd, $J=$ 5.6, 3.6, $1.7 \mathrm{~Hz}, 1 \mathrm{H}), 3.96$ - $3.62(\mathrm{~m}, 4 \mathrm{H}), 3.07$ - $3.03(\mathrm{~m}, 1 \mathrm{H}), 3.02$ - $2.96(\mathrm{~m}, 4 \mathrm{H}), 2.51$ (dddd, J = 12.7, 6.6, 4.5, 2.6 Hz, 1H), 2.45 - $2.30(\mathrm{~m}, 2 \mathrm{H}), 2.27-2.17(\mathrm{~m}, 1 \mathrm{H}), 2.13(\mathrm{~d}, J=12.2 \mathrm{~Hz}, 1 \mathrm{H}), 1.81-1.68(\mathrm{~m}$, 1H). ${ }^{13} \mathrm{C}$ NMR $\left(100 \mathrm{MHz}, \mathrm{CDCl}_{3}\right) \delta 209.01,141.08,133.94,129.91,129.24,128.21,127.08,81.04$, 75.05, 66.10, 55.18, 45.98, 35.87, 35.52, 31.20. IR (KBr, cm $\left.{ }^{-1}\right)$ 2858, 1712, 1348, 1166, 1113, 944, 741. HRMS calcd $\mathrm{C}_{19} \mathrm{H}_{24} \mathrm{NO}_{5} \mathrm{~S}[\mathrm{M}+\mathrm{H}]^{+}: 378.1370$. Found: 378.1375 . 


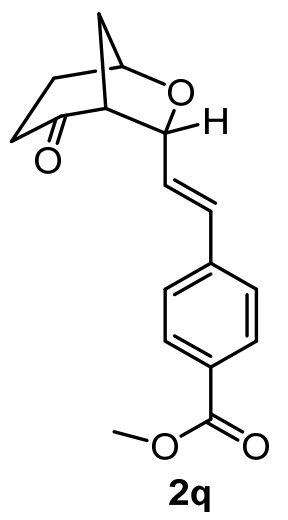

endo-Methyl-4-((E)-2-oxo-6-oxabicyclo[3.2.1]octan-7-yl)vinyl)benzoate (2q): Synthesized from 1r according to "standard conditions A". $60 \%$ yield; exo:endo $=1: 3 ;$ yellow oil; $\mathrm{R}_{f}=0.4$ (hexane $/$ EtOAc $=$ 3:1). ${ }^{1} \mathbf{H}$ NMR $\left(400 \mathrm{MHz}, \mathrm{CDCl}_{3}\right) \delta 8.05-7.89(\mathrm{~m}, 2 \mathrm{H}), 7.40(\mathrm{~d}, J=8.3 \mathrm{~Hz}, 2 \mathrm{H}), 6.80(\mathrm{dd}, J=15.9,1.8$ $\mathrm{Hz}, 1 \mathrm{H}), 6.29(\mathrm{dd}, J=15.9,4.9 \mathrm{~Hz}, 1 \mathrm{H}), 4.81(\mathrm{td}, J=4.6,1.8 \mathrm{~Hz}, 1 \mathrm{H}), 4.67(\mathrm{ddd}, J=5.6,3.6,1.6 \mathrm{~Hz}$, $1 \mathrm{H}), 3.90(\mathrm{~s}, 3 \mathrm{H}), 3.03$ (t, $J=4.3 \mathrm{~Hz}, 1 \mathrm{H}), 2.50$ (dddd, $J=12.6,6.6,4.3,2.6 \mathrm{~Hz}, 1 \mathrm{H}), 2.44-2.37$ (m, 2H), $2.21(\mathrm{ddd}, J=13.8,7.3,3.4 \mathrm{~Hz}, 1 \mathrm{H}), 2.11(\mathrm{~d}, J=12.2 \mathrm{~Hz}, 1 \mathrm{H}), 1.72(\mathrm{dtd}, J=13.8,9.1,1.7 \mathrm{~Hz}, 1 \mathrm{H}) .{ }^{13} \mathbf{C}$ NMR $\left(100 \mathrm{MHz}, \mathrm{CDCl}_{3}\right) \delta 209.13,166.80,140.70,131.03,129.91,129.30,127.78,126.49,81.30,74.97$, 55.22, 52.10, 36.00, 35.57, 31.32. IR $\left(\mathrm{KBr}, \mathrm{cm}^{-1}\right) 2989,1725,1607,1276,1267$. HRMS calcd $\mathrm{C}_{17} \mathrm{H}_{19} \mathrm{O}_{4}$ $[\mathrm{M}+\mathrm{H}]^{+}:$287.1278. Found: 287.1284.

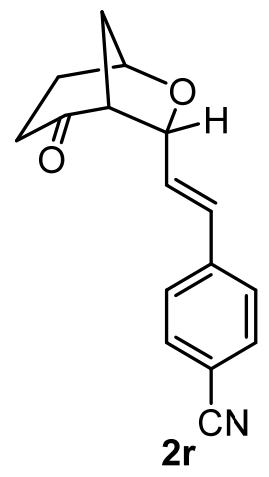

endo-Methyl 4-((E)-2-0xo-6-oxabicyclo[3.2.1]octan-7-yl)vinyl)benzoate (2r): Synthesized from 1s according to "standard conditions A". 68\% yield; exo:endo $=1: 5.8$; yellow oil; $\mathrm{R}_{f}=0.15$ (he xane/EtOAc = 3:1). ${ }^{1} \mathbf{H}$ NMR $\left(400 \mathrm{MHz}, \mathrm{CDCl}_{3}\right) \delta 7.80-7.52(\mathrm{~m}, 2 \mathrm{H}), 7.50-7.36(\mathrm{~m}, 2 \mathrm{H}), 6.78(\mathrm{dd}, J=$ 15.9, $1.9 \mathrm{~Hz}, 1 \mathrm{H}), 6.31(\mathrm{dd}, J=15.9,4.7 \mathrm{~Hz}, 1 \mathrm{H}), 4.81$ (td, $J=4.5,1.9 \mathrm{~Hz}, 1 \mathrm{H}), 4.68$ (ddd, $J=5.6,3.5$, $1.6 \mathrm{~Hz}, 1 \mathrm{H}), 3.03(\mathrm{dd}, J=4.8,3.7 \mathrm{~Hz}, 1 \mathrm{H}), 2.54-2.46(\mathrm{~m}, 1 \mathrm{H}), 2.45$ - $2.29(\mathrm{~m}, 2 \mathrm{H}), 2.26$ - $2.15(\mathrm{~m}, 1 \mathrm{H})$, $2.12(\mathrm{~d}, J=12.2 \mathrm{~Hz}, 1 \mathrm{H}), 1.81-1.68(\mathrm{~m}, 1 \mathrm{H}) .{ }^{13} \mathbf{C} \mathbf{~ N M R}\left(100 \mathrm{MHz}, \mathrm{CDCl}_{3}\right) \delta 208.96,140.71,132.42$, $130.10,129.25,127.08,118.85,111.15,81.05,75.05,55.16,35.87,35.50,31.19$. IR (KBr, cm $\left.{ }^{-1}\right) 2951$, 1713, 1680, 1603, 1410, 1270. HRMS calcd. $\mathrm{C}_{16} \mathrm{H}_{16} \mathrm{NO}_{2}[\mathrm{M}+\mathrm{H}]^{+}:$254.1176. Found: 254.1186. 


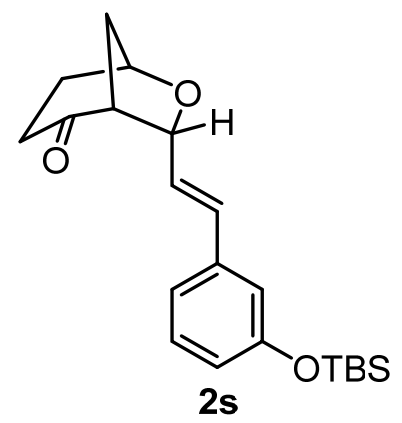

endo-7-((E)-3-((tert-Butyldimethylsilyl)oxy)styryl)-6-oxabicyclo[3.2.1]octan-2-one (2s): Synthesized from 1t according to "standard conditions A". 62\% yield; exo:endo $=1: 4.7$; yellow oil; $\mathrm{R}_{f}=0.30$ (hexane/EtOAc = 3:1). ${ }^{1} \mathbf{H}$ NMR $\left(400 \mathrm{MHz}, \mathrm{CDCl}_{3}\right) \delta 7.15(\mathrm{t}, J=7.8 \mathrm{~Hz}, 1 \mathrm{H}), 6.95(\mathrm{dt}, J=7.7,1.3 \mathrm{~Hz}$, $1 \mathrm{H}), 6.81(\mathrm{t}, J=2.0 \mathrm{~Hz}, 1 \mathrm{H}), 6.76-6.64(\mathrm{~m}, 2 \mathrm{H}), 6.13(\mathrm{dd}, J=15.9,5.1 \mathrm{~Hz}, 1 \mathrm{H}), 4.78$ (ddd, $J=5.4,4.4$, $1.7 \mathrm{~Hz}, 1 \mathrm{H}), 4.65$ (ddd, $J=5.6,3.7,1.6 \mathrm{~Hz}, 1 \mathrm{H}), 3.00$ (t, $J=4.3 \mathrm{~Hz}, 1 \mathrm{H}), 2.55-2.35$ (m, 3H), 2.21 (ddq, $J=14.0,7.1,3.6 \mathrm{~Hz}, 1 \mathrm{H}), 2.09$ (d, $J=12.1 \mathrm{~Hz}, 1 \mathrm{H}), 1.71$ (dtd, $J=13.8,9.9,9.4,1.6 \mathrm{~Hz}, 1 \mathrm{H}), 0.98$ (s, 9H), 0.19 (s, 6H). ${ }^{13} \mathbf{C}$ NMR (100 MHz, $\left.\mathrm{CDCl}_{3}\right) \delta$ 209.27, 155.83, 137.76, 132.01, 129.42, 124.95, 119.76, 119.58, 118.27, 81.51, 74.86, 55.24, 36.16, 35.66, 31.48, 25.70, 18.20, -4.37. IR (KBr, cm $\left.{ }^{-1}\right) 2930,2858$, 1713, 1580, 1288, 1249. HRMS calcd. $\mathrm{C}_{21} \mathrm{H}_{31} \mathrm{O}_{3} \mathrm{Si}[\mathrm{M}+\mathrm{H}]^{+}:$359.2037. Found: 359.2039.

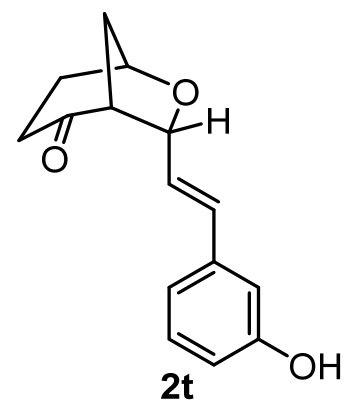

endo-7-((E)-3-Hydroxystyryl)-6-oxabicyclo[3.2.1]octan-2-one (2t): Synthesized from 1u according to “standard conditions A". $63 \%$ yield; exo:endo $=1: 6$; white solid; M.p. $156-158{ }^{\circ} \mathrm{C} ; \mathrm{R}_{f}=0.3$ (hexane/EtOAc = 1:1). ${ }^{1} \mathbf{H}$ NMR $\left(400 \mathrm{MHz}, \mathrm{CDCl}_{3}\right) \delta 7.16(\mathrm{t}, J=7.9 \mathrm{~Hz}, 1 \mathrm{H}), 6.90(\mathrm{dt}, J=7.6,1.3 \mathrm{~Hz}$, $1 \mathrm{H}), 6.81(\mathrm{t}, J=2.1 \mathrm{~Hz}, 1 \mathrm{H}), 6.75-6.67(\mathrm{~m}, 2 \mathrm{H}), 6.14(\mathrm{dd}, J=15.9,5.2 \mathrm{~Hz}, 1 \mathrm{H}), 5.15(\mathrm{~s}, 1 \mathrm{H}), 4.79$ (ddd, $J=5.6,4.3,1.8 \mathrm{~Hz}, 1 \mathrm{H}), 4.66(\mathrm{ddd}, J=5.6,3.6,1.6 \mathrm{~Hz}, 1 \mathrm{H}), 3.01(\mathrm{t}, J=4.3 \mathrm{~Hz}, 1 \mathrm{H}), 2.55-2.33(\mathrm{~m}, 3 \mathrm{H})$, $2.27-2.16(\mathrm{~m}, 1 \mathrm{H}), 2.10(\mathrm{~d}, J=12.3 \mathrm{~Hz}, 1 \mathrm{H}), 1.72(\mathrm{dtd}, J=13.8,9.2,1.7 \mathrm{~Hz}, 1 \mathrm{H}) .{ }^{13} \mathbf{C}$ NMR $(100 \mathrm{MHz}$, $\left.\mathrm{CDCl}_{3}\right) \delta 209.54,155.81,137.95,131.85,129.77,125.31,119.43,114.99,113.15,81.48,74.90,55.24$, 36.03, 35.60, 31.37. IR $\left(\mathrm{KBr}, \mathrm{cm}^{-1}\right) 3315,3006,1710,1582,1461,1276$. HRMS calcd $\mathrm{C}_{15} \mathrm{H}_{17} \mathrm{O}_{3}[\mathrm{M}+\mathrm{H}]^{+}$: 245.1172. Found: 245.1176. 


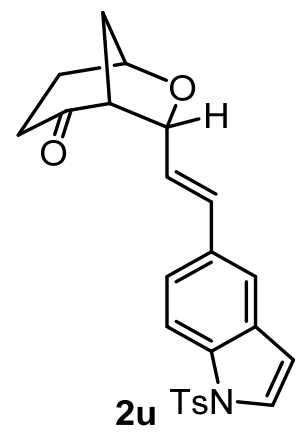

endo-7-((E)-2-(1-Tosyl-1H-indol-5-yl)vinyl)-6-oxabicyclo[3.2.1]octan-2-one (2u): Synthesized from $1 \mathbf{w}$ according to "standard conditions A". $62 \%$ yield; exo:endo $=1: 1.8$; pale oil; $\mathrm{R}_{f}=0.3$ (hexane/EtOAc =2:1). ${ }^{1} \mathbf{H}$ NMR $\left(400 \mathrm{MHz}, \mathrm{CDCl}_{3}\right) \delta 7.16(\mathrm{t}, J=7.9 \mathrm{~Hz}, 1 \mathrm{H}), 6.90(\mathrm{dt}, J=7.6,1.3 \mathrm{~Hz}, 1 \mathrm{H}), 6.81(\mathrm{t}, J=$ $2.1 \mathrm{~Hz}, 1 \mathrm{H}), 6.75-6.67(\mathrm{~m}, 2 \mathrm{H}), 6.14(\mathrm{dd}, J=15.9,5.2 \mathrm{~Hz}, 1 \mathrm{H}), 5.15(\mathrm{~s}, 1 \mathrm{H}), 4.79$ (ddd, $J=5.6,4.3,1.8$ $\mathrm{Hz}, 1 \mathrm{H}), 4.66(\mathrm{ddd}, J=5.6,3.6,1.6 \mathrm{~Hz}, 1 \mathrm{H}), 3.01(\mathrm{t}, J=4.3 \mathrm{~Hz}, 1 \mathrm{H}), 2.55$ - $2.33(\mathrm{~m}, 3 \mathrm{H}), 2.27$ - 2.16 (m, $1 \mathrm{H}), 2.10(\mathrm{~d}, J=12.3 \mathrm{~Hz}, 1 \mathrm{H}), 1.72(\mathrm{dtd}, J=13.8,9.2,1.7 \mathrm{~Hz}, 1 \mathrm{H}) .{ }^{13} \mathbf{C} \mathbf{N M R}\left(100 \mathrm{MHz}, \mathrm{CDCl}_{3}\right) \delta$ 209.42, 144.99, 135.15, 134.49, 132.12, 131.85, 131.10, 129.90, 126.96, 126.76, 124.29, 123.24, 119.63, $113.60,109.21,81.60,74.85,55.33,36.02,35.62,31.39,21.58$. IR $\left(\mathrm{KBr}, \mathrm{cm}^{-1}\right) 2952,1712,1276,1273$, 1261, 764. HRMS calcd $\mathrm{C}_{24} \mathrm{H}_{24} \mathrm{NO}_{4} \mathrm{~S}[\mathrm{M}+\mathrm{H}]^{+}: 422.1421$. Found: 422.1425.

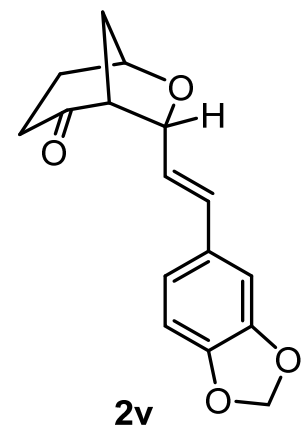

endo-7-((E)-2-(Benzo[d][1,3]dioxol-5-yl)vinyl)-6-oxabicyclo[3.2.1]octan-2-one (2v): Synthesized from $1 \mathbf{x}$ according to "standard conditions $A$ ". $60 \%$ yield; exo:endo $=1: 5.1 ;$ pale oil; $\mathrm{R}_{f}=0.35$ (hexane/EtOAc = 3:1). ${ }^{1} \mathbf{H}$ NMR $\left(400 \mathrm{MHz}, \mathrm{CDCl}_{3}\right) \delta 6.87(\mathrm{~d}, J=1.6 \mathrm{~Hz}, 1 \mathrm{H}), 6.78(\mathrm{dd}, J=8.0,1.7 \mathrm{~Hz}, 1 \mathrm{H}), 6.73(\mathrm{~d}, J=$ $8.0 \mathrm{~Hz}, 1 \mathrm{H}), 6.65(\mathrm{dd}, J=15.8,1.7 \mathrm{~Hz}, 1 \mathrm{H}), 5.99(\mathrm{dd}, J=15.8,5.4 \mathrm{~Hz}, 1 \mathrm{H}), 5.94(\mathrm{~s}, 2 \mathrm{H}), 4.75(\mathrm{ddd}, J=$ 5.6, 4.1, $1.7 \mathrm{~Hz}, 1 \mathrm{H}), 4.64(\mathrm{ddd}, J=5.7,3.7,1.6 \mathrm{~Hz}, 1 \mathrm{H}), 2.97(\mathrm{td}, J=4.3,0.8 \mathrm{~Hz}, 1 \mathrm{H}), 2.51-2.36(\mathrm{~m}$, $3 \mathrm{H}), 2.27-2.14(\mathrm{~m}, 1 \mathrm{H}), 2.08(\mathrm{~d}, J=12.2 \mathrm{~Hz}, 1 \mathrm{H}), 1.78-1.65(\mathrm{~m}, 1 \mathrm{H}) .{ }^{13} \mathbf{C}$ NMR $\left(100 \mathrm{MHz}, \mathrm{CDCl}_{3}\right) \delta$ 209.38, 147.99, 147.46, 131.99, 130.74, 122.98, 121.40, 108.23, 105.91, 101.11, 81.65, 74.81, 55.31, 36.08, 35.63, 31.42. IR (KBr, $\left.\mathrm{cm}^{-1}\right) 2950,1713,1503$, 1490, 1446, 1245. HRMS calcd. $\mathrm{C}_{16} \mathrm{H}_{17} \mathrm{O}_{4}$ $[\mathrm{M}+\mathrm{H}]^{+}:$273.1121. Found: 273.1126 . 


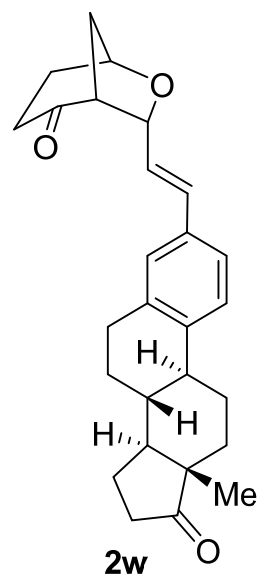

endo-7-((E)-2-((8R,9S,13S)-13-Methyl-17-0xo-7,8,9,11,12,13,14,15,16,17-decahydro-6Hcyclopenta[a]phenanthren-3-yl)vinyl)-6-oxabicyclo[3.2.1]octan-2-one (2w): Synthesized from 1 ad according to "standard conditions A". 68\% yield; exo: endo=1:3.5; white solid; M.p.136 $-138{ }^{\circ} \mathrm{C}$; $\mathrm{R}_{f}=0.25$ (hexane/EtOAc = 3:1). ${ }^{1} \mathbf{H}$ NMR $\left(400 \mathrm{MHz}, \mathrm{CDCl}_{3}\right) \delta 7.23(\mathrm{~d}, J=8.0 \mathrm{~Hz}, 1 \mathrm{H}), 7.17$ - 7.07 (m, 2H), $6.71(\mathrm{dd}, J=15.9,1.8 \mathrm{~Hz}, 1 \mathrm{H}), 6.13(\mathrm{ddd}, J=15.9,5.2,0.9 \mathrm{~Hz}, 1 \mathrm{H}), 4.78$ (q, $J=3.0,1.5 \mathrm{~Hz}, 1 \mathrm{H})$, 4.65 (ddd, $J=5.6,3.7,1.5 \mathrm{~Hz}, 1 \mathrm{H}), 2.99$ (t, $J=4.2 \mathrm{~Hz}, 1 \mathrm{H}), 2.89$ (dd, $J=9.0,4.3 \mathrm{~Hz}, 2 \mathrm{H}), 2.55-2.35$ (m, 5H), 2.33-1.90 (m, 6H), 1.78 - 1.37 (m, 8H), 0.90 (s, 3H). ${ }^{13} \mathbf{C}$ NMR (100 MHz, $\left.\mathrm{CDCl}_{3}\right) \delta 220.86,209.35$, 139.67, 136.64, 133.89, 131.85, 127.13, 125.57, 124.19, 124.12, 81.63, 74.83, 55.30, 50.50, 47.99, 44.44, $38.13,36.14,35.87,35.66,31.58,31.49,29.34,26.47,25.71,21.60$, 13.85.IR $\left(\mathrm{K} \mathrm{Br}, \mathrm{cm}^{-1}\right)$ 2931, 1736, 1716, 1276, 1261, 1065. HRMS calcd $\mathrm{C}_{27} \mathrm{H}_{33} \mathrm{O}_{3}[\mathrm{M}+\mathrm{H}]^{+}:$405.2424. Found: 405.2414.

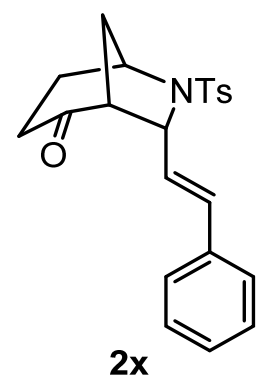

endo-7-((E)-Styryl)-6-tosyl-6-azabicyclo[3.2.1]octan-2-one (2x): Synthesized from $1 z$ according to “standard conditions A". $61 \%$ yield; exo:endo $=1: 4$; pale oil; $\mathrm{R}_{f}=0.3$ (hexane/EtOAc $=3: 1$ ). ${ }^{1} \mathbf{H}$ NMR $\left(400 \mathrm{MHz}, \mathrm{CDCl}_{3}\right) \delta 7.77(\mathrm{~d}, J=8.3 \mathrm{~Hz}, 2 \mathrm{H}), 7.37$ - $7.24(\mathrm{~m}, 6 \mathrm{H}), 7.27$ - 7.20 (m, 1H), 6.65 (dd, $J=16.0$, $1.6 \mathrm{~Hz}, 1 \mathrm{H}), 6.20$ (dd, $J=16.0,5.9 \mathrm{~Hz}, 1 \mathrm{H}), 4.52-4.40(\mathrm{~m}, 1 \mathrm{H}), 4.31$ (td, $J=5.6,1.6 \mathrm{~Hz}, 1 \mathrm{H}), 2.99$ (t, $J$ $=5.4 \mathrm{~Hz}, 1 \mathrm{H}), 2.62-2.49(\mathrm{~m}, 2 \mathrm{H}), 2.43(\mathrm{~s}, 3 \mathrm{H}), 2.39-2.24(\mathrm{~m}, 1 \mathrm{H}), 1.82-1.68(\mathrm{~m}, 2 \mathrm{H}), 1.63-1.56(\mathrm{~m}$, 1H). ${ }^{13} \mathbf{C}$ NMR $\left(100 \mathrm{MHz}, \mathrm{CDCl}_{3}\right) \delta 208.12,144.03,136.05,134.66,133.45,129.93,128.48,127.99$, $127.74,126.69,124.76,64.64,58.04,56.25,36.02,34.53,31.69,21.58$. IR $\left(\mathrm{KBr}, \mathrm{cm}^{-1}\right)$ 3059, 2926, 1716, 1345, 1158, 1089. HRMS calcd. $\mathrm{C}_{22} \mathrm{H}_{24} \mathrm{NO}_{3} \mathrm{~S}[\mathrm{M}+\mathrm{H}]^{+}: 382.1471$. Found: 382.1465 . 


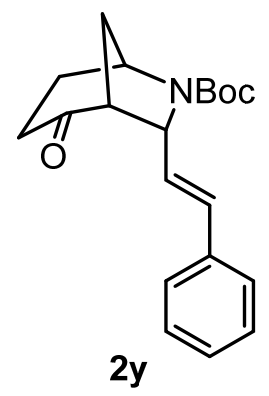

endo-tert-Butyl-2-oxo-7-((E)-styryl)-6-azabicyclo[3.2.1]octane-6-carboxylate (2y): Synthesized from 1y according to "standard conditions A". $76 \%$ yield; exo:endo $=1: 3.3$; pale oil; $\mathrm{R}_{f}=0.35$ (hexane/EtOAc = 3:1). ${ }^{1} \mathbf{H}$ NMR $\left(400 \mathrm{MHz}, \mathrm{CDCl}_{3}\right)$ (mixture of rotamers) $\delta 7.30(\mathrm{~m}, 4 \mathrm{H}), 7.26-7.18(\mathrm{~m}$, $1 \mathrm{H}), 6.53(\mathrm{dd}, J=15.9,1.5 \mathrm{~Hz}, 1 \mathrm{H}), 6.23-5.98(\mathrm{~m}, 1 \mathrm{H}), 4.48(\mathrm{~m}, 2 \mathrm{H}), 3.06(\mathrm{t}, J=4.7 \mathrm{~Hz}, 1 \mathrm{H}), 2.52$ $2.36(\mathrm{~m}, 2 \mathrm{H}), 2.24$ (dddd, $J=12.6,5.6,4.4,2.6 \mathrm{~Hz}, 2 \mathrm{H}), 1.88(\mathrm{~d}, J=12.1 \mathrm{~Hz}, 1 \mathrm{H}), 1.83-1.69$ (m, 1H), 1.59 - 1.34 (m, 9H). ${ }^{13} \mathbf{C}$ NMR (100 MHz, $\left.\mathbf{C D C l}_{3}\right) \delta$ 209.24, 154.84, 136.51, 132.43, 128.55, 127.69, $126.39,125.78,80.16,62.45,56.51,55.03,36.24,34.64,32.29,30.04,28.47,28.40$. IR $\left(\mathrm{KBr}, \mathrm{cm}^{-1}\right) 2975$, 1691, 1392, 1366, 1166, 1116. HRMS calcd. $\mathrm{C}_{20} \mathrm{H}_{26} \mathrm{NO}_{3}[\mathrm{M}+\mathrm{H}]^{+}:$328.1907. Found: 328.1897.

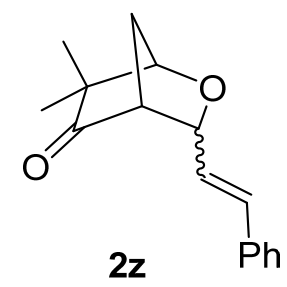

6,6-Dimethyl-3-styryl-2-oxabicyclo[2.2.1]heptan-5-one (2z). Synthesized from 1ae according to “standard conditions A”. 10\% yield; pale oil; $\mathrm{R}_{f}=0.45$ (hexane/EtOAc $\left.=3: 1\right) .{ }^{1} \mathbf{H}$ NMR (400 MHz, $\left.\mathrm{CDCl}_{3}\right) \delta 7.41-7.29(\mathrm{~m}, 5 \mathrm{H}), 6.67(\mathrm{dd}, J=15.7,1.4 \mathrm{~Hz}, 1 \mathrm{H}), 6.09(\mathrm{dd}, J=15.7,5.6 \mathrm{~Hz}, 1 \mathrm{H}), 4.55-4.39$ (m, 1H), $4.31(\mathrm{~d}, J=2.6 \mathrm{~Hz}, 1 \mathrm{H}), 2.77$ (d, $J=1.5 \mathrm{~Hz}, 1 \mathrm{H}), 2.24-1.99(\mathrm{~m}, 2 \mathrm{H}), 1.18(\mathrm{~s}, 3 \mathrm{H}), 1.02(\mathrm{~s}, 3 \mathrm{H})$. ${ }^{13}$ NMR $\left(101 \mathrm{MHz}, \mathrm{CDCl}_{3}\right) \delta 217.97,136.25,132.20,128.62,127.95,127.00,126.60,83.92,76.39,55.95$, 49.85, 31.02, 21.08, 19.86. IR $\left(\mathrm{KBr}, \mathrm{cm}^{-1}\right) 3001,1716,1456,1276,1261,1065$. HRMS calcd $\mathrm{C}_{16} \mathrm{H}_{19} \mathrm{O}_{2}$ $[\mathrm{M}+\mathrm{H}]^{+}:$243.1380. Found: 243.1388.

2. exo-2'. 


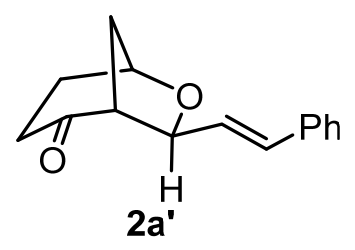

exo-7-((E)-Styryl)-6-oxabicyclo[3.2.1]octan-2-one (2a'): Synthesized from 1a according to "standard conditions B". The exo structure is determined by COSY and NOESY analysis (vide infra). 68\% yield; exo:endo = 13:1; yellow oil; $R_{f}=0.35$ (hexane/EtOAc = 3:1). ${ }^{1} \mathbf{H}$ NMR $\left(400 \mathrm{MHz}, \mathrm{CDCl}_{3}\right) \delta 7.44-7.28$ (m, 4H), $7.27-7.21(\mathrm{~m}, 1 \mathrm{H}), 6.64(\mathrm{dd}, J=15.7,1.5 \mathrm{~Hz}, 1 \mathrm{H}), 6.11(\mathrm{dd}, J=15.7,5.5 \mathrm{~Hz}, 1 \mathrm{H}), 4.78(\mathrm{dd}, J$ $=5.5,1.5 \mathrm{~Hz}, 1 \mathrm{H}), 4.70(\mathrm{ddd}, J=5.6,3.7,1.3 \mathrm{~Hz}, 1 \mathrm{H}), 2.85-2.75(\mathrm{~m}, 1 \mathrm{H}), 2.63(\mathrm{ddd}, J=17.0,10.4,9.4$ $\mathrm{Hz}, 1 \mathrm{H}), 2.41$ (dddd, $J=17.2,10.1,5.1,3.2 \mathrm{~Hz}, 2 \mathrm{H}), 2.29-2.15(\mathrm{~m}, 1 \mathrm{H}), 1.93$ (d, $J=12.3 \mathrm{~Hz}, 1 \mathrm{H}), 1.74$ (dddd, $J=13.7,10.5,7.8,1.6 \mathrm{~Hz}, 1 \mathrm{H}) .{ }^{13} \mathbf{C} \mathbf{~ N M R}\left(100 \mathrm{MHz}, \mathrm{CDCl}_{3}\right) \delta 210.11,136.29,131.09,128.61$, 128.46, 127.85, 126.59, 80.81, 75.14, 55.77, 34.65, 33.33, 32.09. IR (KBr, $\left.\mathrm{cm}^{-1}\right)$ 2953, 1711, 1448, 1275 , 1261, 1090. HRMS calcd. $\mathrm{C}_{15} \mathrm{H}_{17} \mathrm{O}_{2}[\mathrm{M}+\mathrm{H}]^{+}:$229.1223. Found: 229.1218.

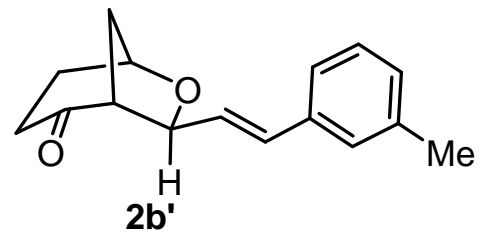

exo-7-((E)-3-Methylstyryl)-6-oxabicyclo[3.2.1]octan-2-one (2b'): Synthesized from 1d according to “standard conditions B". $62 \%$ yield; exo:endo $=10: 1$; yellow oil; $R_{f}=0.35$ (hexane/EtOAc $\left.=3: 1\right) .{ }^{1} \mathbf{H}$ NMR $\left(500 \mathrm{MHz}, \mathrm{CDCl}_{3}\right) \delta 7.23-7.13(\mathrm{~m}, 3 \mathrm{H}), 7.06(\mathrm{dtd}, \mathrm{J}=7.1,1.6,0.8 \mathrm{~Hz}, 1 \mathrm{H}), 6.61(\mathrm{dd}, \mathrm{J}=15.7$, $1.4 \mathrm{~Hz}, 1 \mathrm{H}), 6.09$ (dd, $J=15.7,5.6 \mathrm{~Hz}, 1 \mathrm{H}), 4.77$ (dd, $J=5.6,1.4 \mathrm{~Hz}, 1 \mathrm{H}), 4.69$ (ddd, $J=5.5,3.7,1.3 \mathrm{~Hz}$, 1H), 2.86 - 2.77 (m, 1H), $2.62(\mathrm{ddd}, J=16.9,10.4,9.5 \mathrm{~Hz}, 1 \mathrm{H}), 2.47-2.36$ (m, 2H), 2.34 (d, $J=0.7 \mathrm{~Hz}$, $3 \mathrm{H}), 2.28-2.15(\mathrm{~m}, 1 \mathrm{H}), 1.93(\mathrm{~d}, J=12.3 \mathrm{~Hz}, 1 \mathrm{H}), 1.74(\mathrm{dddd}, J=13.7,10.5,7.8,1.6 \mathrm{~Hz}, 1 \mathrm{H}) .{ }^{13} \mathbf{C}$ NMR $\left(100 \mathrm{MHz}, \mathrm{CDCl}_{3}\right) \delta 210.19,138.18,136.22,131.20,128.65,128.51,128.21,127.29,123.75$, 80.88, 75.12, 55.81, 34.67, 33.36, 32.11, 21.39. IR (KBr, cm $\left.\mathrm{cm}^{-1}\right)$ 2950, 1710, 1444, 1226, 1088, 980. HRMS calcd $\mathrm{C}_{16} \mathrm{H}_{19} \mathrm{O}_{2}[\mathrm{M}+\mathrm{H}]^{+}:$243.1380. Found: 243.1388 .

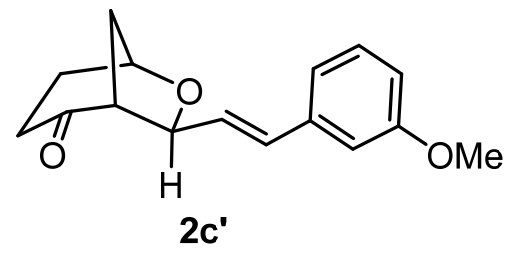


exo-7-((E)-3-Methoxystyryl)-6-oxabicyclo [3.2.1] octan-2-one (2c'): Synthesized from 1e according to “standard conditions B”. 58\%; exo:endo $=10: 1$; yellow oil ; $R_{f}=0.35$ (hexane/EtOAc $=3: 1$ ). ${ }^{1} \mathbf{H}$ NMR $\left(400 \mathrm{MHz}, \mathrm{CDCl}_{3}\right) \delta 7.23(\mathrm{t}, J=7.9 \mathrm{~Hz}, 1 \mathrm{H}), 6.96(\mathrm{dt}, J=7.6,1.2 \mathrm{~Hz}, 1 \mathrm{H}), 6.90(\mathrm{dd}, J=2.6,1.6 \mathrm{~Hz}, 1 \mathrm{H})$, $6.80(\mathrm{ddd}, J=8.2,2.6,0.9 \mathrm{~Hz}, 1 \mathrm{H}), 6.61(\mathrm{dd}, J=15.7,1.5 \mathrm{~Hz}, 1 \mathrm{H}), 6.10(\mathrm{dd}, J=15.7,5.5 \mathrm{~Hz}, 1 \mathrm{H}), 4.78$ $(\mathrm{dd}, J=5.5,1.5 \mathrm{~Hz}, 1 \mathrm{H}), 4.69(\mathrm{ddd}, J=5.7,3.9,1.3 \mathrm{~Hz}, 1 \mathrm{H}), 3.81(\mathrm{~s}, 3 \mathrm{H}), 2.81(\mathrm{~d}, J=4.8 \mathrm{~Hz}, 1 \mathrm{H}), 2.69$ - 2.54 (m, 1H), 2.48 - 2.32 (m, 2H), 2.28 - 2.14 (m, 1H), 1.93 (d, $J=12.3 \mathrm{~Hz}, 1 \mathrm{H}), 1.74$ (dddd, $J=13.7$, 10.6, 7.8, $1.5 \mathrm{~Hz}, 1 \mathrm{H}) .{ }^{13} \mathrm{C}$ NMR $\left(100 \mathrm{MHz}, \mathrm{CDCl}_{3}\right) \delta 210.10,159.81,137.73,131.00,129.59,128.77$, 119.23, 113.50, 111.90, 80.75, 75.15, 55.75, 55.24, 34.65, 33.33, 32.08. IR (KBr, cm $\left.{ }^{-1}\right) 2951,1711,1580$, 1269, 1156, 1090. HRMS calcd. $\mathrm{C}_{16} \mathrm{H}_{19} \mathrm{O}_{3}[\mathrm{M}+\mathrm{H}]^{+}:$259.1329. Found: 259.1336.

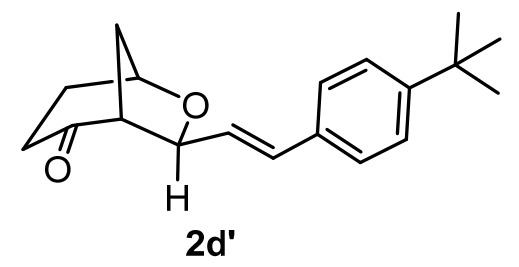

exo-7-((E)-4-(tert-Butyl)styryl)-6-oxabicyclo[3.2.1]octan-2-one (2d'): Synthesized from 1f according to "standard conditions B". 70\% yield; exo:endo $=11: 1$; pale oil; $R_{f}=0.50$ (hexane/EtOAc $\left.=3: 1\right)$. ${ }^{1} \mathbf{H}$ NMR (400 MHz, $\left.\mathrm{CDCl}_{3}\right) \delta 7.43-7.30(\mathrm{~m}, 4 \mathrm{H}), 6.62(\mathrm{dd}, J=15.7,1.5 \mathrm{~Hz}, 1 \mathrm{H}), 6.07$ (dd, $J=15.7,5.5 \mathrm{~Hz}$, $1 \mathrm{H}), 4.78(\mathrm{dd}, J=5.6,1.5 \mathrm{~Hz}, 1 \mathrm{H}), 4.69$ (ddd, $J=5.7,3.9,1.3 \mathrm{~Hz}, 1 \mathrm{H}), 2.79$ (d, $J=4.8 \mathrm{~Hz}, 1 \mathrm{H}), 2.69$ $2.51(\mathrm{~m}, 1 \mathrm{H}), 2.47-2.31(\mathrm{~m}, 1 \mathrm{H}), 2.28-2.12(\mathrm{~m}, 1 \mathrm{H}), 1.92$ (d, J=12.3 Hz, 1H), $1.74(\mathrm{~m}, 1 \mathrm{H}), 1.31$ (s, 9H). ${ }^{13} \mathrm{C}$ NMR $\left(100 \mathrm{MHz}, \mathrm{CDCl}_{3}\right) \delta 210.25,151.03,133.50,130.82,127.67,126.30,125.54,80.92$, 75.11, 55.87, 34.67, 34.61, 33.34, 32.12, 31.28. IR (KBr, cm $\left.{ }^{-1}\right)$ 2960, 1711, 1088, 1066, 980, 896. HRMS calcd $\mathrm{C}_{19} \mathrm{H}_{25} \mathrm{O}_{2}[\mathrm{M}+\mathrm{H}]^{+}: 285.1849$. Found: 285.1854.

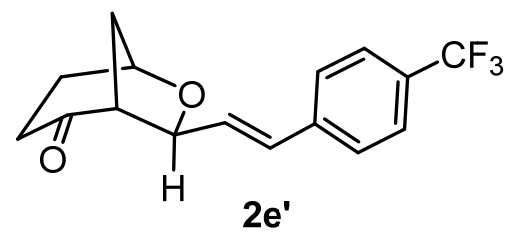

exo-7-((E)-4-(Trifluoromethyl)styryl)-6-oxabicyclo[3.2.1]octan-2-one (2e'); Synthesized from $1 \mathrm{~g}$ according to "standard conditions B". $64 \%$ yield; exo: endo $=11: 1$; pale oil; $R_{f}=0.35$ (hexane $/$ EtOAc $=$ 3:1). ${ }^{1}$ H NMR $\left(400 \mathrm{MHz}, \mathrm{CDCl}_{3}\right) \delta 7.56(\mathrm{~d}, J=8.2 \mathrm{~Hz}, 2 \mathrm{H}), 7.45(\mathrm{~d}, J=8.1 \mathrm{~Hz}, 2 \mathrm{H}), 6.69$ (dd, $J=15.8$, $1.6 \mathrm{~Hz}, 1 \mathrm{H}), 6.21(\mathrm{dd}, J=15.7,5.2 \mathrm{~Hz}, 1 \mathrm{H}), 4.80(\mathrm{dd}, J=5.3,1.5 \mathrm{~Hz}, 1 \mathrm{H}), 4.71(\mathrm{ddd}, J=5.5,3.7,1.4 \mathrm{~Hz}$, $1 \mathrm{H}), 2.82(\mathrm{~d}, J=4.7 \mathrm{~Hz}, 1 \mathrm{H}), 2.62(\mathrm{ddd}, J=17.0,10.4,9.4 \mathrm{~Hz}, 1 \mathrm{H}), 2.50-2.33(\mathrm{~m}, 1 \mathrm{H}), 2.31$ - $2.14(\mathrm{~m}$, 2H), $1.95(\mathrm{~d}, J=12.3 \mathrm{~Hz}, 1 \mathrm{H}), 1.75$ (dddd, $J=13.7,10.5,7.8,1.6 \mathrm{~Hz}, 1 \mathrm{H}) .{ }^{13} \mathbf{C} \mathbf{N M R}\left(100 \mathrm{MHz}, \mathrm{CDCl}_{3}\right)$ $\delta 209.78,139.74,131.16,129.73,129.63\left(\mathrm{~d},{ }^{3} J_{\mathrm{C}-\mathrm{F}}=32.5 \mathrm{~Hz}\right), 126.74,125.57\left(\mathrm{q},{ }^{1} J_{\mathrm{C}-\mathrm{F}}=3.8 \mathrm{~Hz}\right) .124 .14(\mathrm{~d}$, 
$\left.{ }^{2} J_{\mathrm{C}-\mathrm{F}}=277.3 \mathrm{~Hz}\right), 80.44,75.30,55.56,34.59,33.24,32.00 . \quad$ IR $\left(\mathrm{KBr}, \mathrm{cm}^{-1}\right) 2955,1711,1326,1164,1122$, 1067. HRMS calcd $\mathrm{C}_{16} \mathrm{H}_{16} \mathrm{~F}_{3} \mathrm{O}_{2}[\mathrm{M}+\mathrm{H}]^{+}: 297.1097$. Found: 297.1104 .

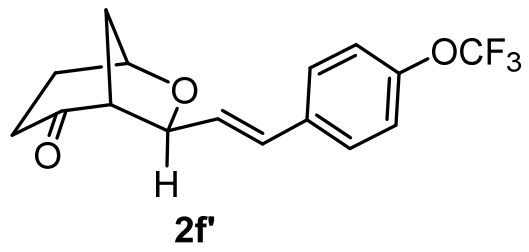

exo-7-((E)-4-(Trifluoromethoxy)styryl)-6-oxabicyclo[3.2.1]octan-2-one (2f'): Synthesized from 1d according to "standard conditions B". $60 \%$ yield; exo:endo $=13: 1$; white solid; M.p. $100-102{ }^{\circ} \mathrm{C} ; R_{f}=$ 0.35 (hexane/EtOAc = 3:1). ${ }^{1} \mathbf{H}$ NMR $\left(400 \mathrm{MHz} \mathrm{CDCl}_{3}\right) \delta 7.45-7.28(\mathrm{~m}, 2 \mathrm{H}), 7.16(\mathrm{dt}, J=7.7,1.1 \mathrm{~Hz}$, 2H), $6.64(\mathrm{dd}, J=15.8,1.5 \mathrm{~Hz}, 1 \mathrm{H}), 6.09(\mathrm{dd}, J=15.7,5.4 \mathrm{~Hz}, 1 \mathrm{H}), 4.78(\mathrm{dd}, J=5.4,1.5 \mathrm{~Hz}, 1 \mathrm{H}), 4.70$ (ddd, $J=5.5,3.7,1.4 \mathrm{~Hz}, 1 \mathrm{H}), 2.81(\mathrm{~d}, J=4.7 \mathrm{~Hz}, 1 \mathrm{H}), 2.70-2.53(\mathrm{~m}, 1 \mathrm{H}), 2.44(\mathrm{~d}, J=7.7 \mathrm{~Hz}, 1 \mathrm{H})$, $2.42-2.32(\mathrm{~m}, 1 \mathrm{H}), 2.30-2.14(\mathrm{~m}, 1 \mathrm{H}), 1.94(\mathrm{~d}, J=12.3 \mathrm{~Hz}, 1 \mathrm{H}), 1.75$ (dddd, $J=13.8,10.5,7.8,1.6 \mathrm{~Hz}$, $1 \mathrm{H}) .{ }^{13} \mathrm{C}$ NMR $\left(100 \mathrm{MHz}, \mathrm{CDCl}_{3}\right) \delta 209.92,148.66\left(\mathrm{~d}, J_{\mathrm{C}-\mathrm{F}}=1.8 \mathrm{~Hz}\right), 135.04,129.62,129.53,127.82$, $121.11,120.44\left(\mathrm{q}, J_{\mathrm{C}-\mathrm{F}}=257.2 \mathrm{~Hz}\right), 80.56,75.22,55.66,34.61,33.26,32.03 . \mathbf{I R}\left(\mathrm{KBr}, \mathrm{cm}^{-1}\right) 2956,1712$, 1508, 1265, 1218, 1163. HRMS calcd $\mathrm{C}_{16} \mathrm{H}_{16} \mathrm{~F}_{3} \mathrm{O}_{3}[\mathrm{M}+\mathrm{H}]^{+}:$313.1046. Found: 313.1036.

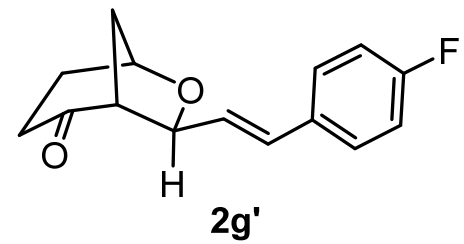

exo-7-((E)-4-Fluorostyryl)-6-oxabicyclo[3.2.1]octan-2-one (2g'): Synthesized from 1d according to "standard conditions B". $66 \%$ yield; exo: endo $=12: 1$; yellow oil; $R_{f}=0.3$ (hexane/EtOAc $\left.=3: 1\right) .{ }^{1} \mathbf{H}$ NMR (400 MHz, $\left.\mathrm{CDCl}_{3}\right) \delta 7.47-7.27(\mathrm{~m}, 2 \mathrm{H}), 7.12$ - $6.91(\mathrm{~m}, 2 \mathrm{H}), 6.60(\mathrm{dd}, J=15.7,1.4 \mathrm{~Hz}, 1 \mathrm{H}), 6.02$ $(\mathrm{dd}, J=15.7,5.5 \mathrm{~Hz}, 1 \mathrm{H}), 4.76(\mathrm{dd}, J=5.7,1.5 \mathrm{~Hz}, 1 \mathrm{H}), 4.69(\mathrm{td}, J=3.9,1.8 \mathrm{~Hz}, 1 \mathrm{H}), 2.80(\mathrm{~d}, J=4.8$ $\mathrm{Hz}, 1 \mathrm{H}), 2.62(\mathrm{ddd}, J=17.0,10.5,9.4 \mathrm{~Hz}, 1 \mathrm{H}), 2.48-2.31(\mathrm{~m}, 2 \mathrm{H}), 2.29-2.13(\mathrm{~m}, 1 \mathrm{H}), 1.93(\mathrm{~d}, J=12.3$ $\mathrm{Hz}, 1 \mathrm{H}), 1.74$ (dddd, $J=13.7,10.5,7.8,1.6 \mathrm{~Hz}, 1 \mathrm{H}) .{ }^{13} \mathbf{C}$ NMR $\left(100 \mathrm{MHz}, \mathrm{CDCl}_{3}\right) \delta 210.04,162.43(\mathrm{~d}$, $\left.{ }^{1} J_{\mathrm{C}-\mathrm{F}}=247.1 \mathrm{~Hz}\right), 132.44\left(\mathrm{~d},{ }^{4} J_{\mathrm{C}-\mathrm{F}}=3.4 \mathrm{~Hz}\right), 129.99,128.16,128.13\left(\mathrm{~d},{ }^{3} J_{\mathrm{C}-\mathrm{F}}=9.9 \mathrm{~Hz}\right), 115.53\left(\mathrm{~d},{ }^{2} J_{\mathrm{C}-\mathrm{F}}=\right.$ 21.6 Hz), 80.74, 75.16, 55.75, 34.63, 33.33, 32.06. IR (KBr, cm $\left.{ }^{-1}\right)$ 2952, 1711, 1509, 1225, 1088, 983. HRMS calcd $\mathrm{C}_{15} \mathrm{H}_{16} \mathrm{FO}_{2}[\mathrm{M}+\mathrm{H}]^{+}:$247.1129. Found: 247.1138. 


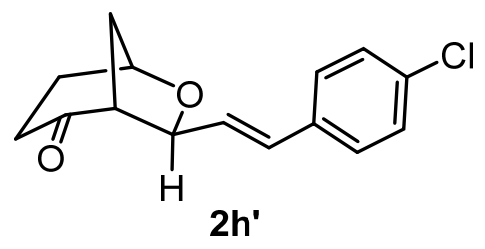

exo-7-((E)-4-Chlorostyryl)-6-oxabicyclo[3.2.1]octan-2-one (2h'): Synthesized from $\mathbf{1 j}$ according to “standard conditions B". $68 \%$ yield; exo:endo $=13: 1$; yellow oil; $\mathrm{R}_{f}=0.3$ (hexane/EtOAc $\left.=3: 1\right) .{ }^{1} \mathbf{H}$ NMR $\left(400 \mathrm{MHz}, \mathrm{CDCl}_{3}\right) \delta 7.29(\mathrm{~s}, 4 \mathrm{H}), 6.60(\mathrm{dd}, J=15.7,1.5 \mathrm{~Hz}, 1 \mathrm{H}), 6.08(\mathrm{dd}, J=15.7,5.5 \mathrm{~Hz}, 1 \mathrm{H})$, $4.77(\mathrm{dd}, J=5.5,1.5 \mathrm{~Hz}, 1 \mathrm{H}), 4.69(\mathrm{ddd}, J=5.6,3.7,1.4 \mathrm{~Hz}, 1 \mathrm{H}), 2.89-2.75(\mathrm{~m}, 1 \mathrm{H}), 2.62(\mathrm{ddd}, J=$ 17.0, 10.2, $9.3 \mathrm{~Hz}, 1 \mathrm{H}), 2.48-2.30$ (m, 2H), $2.29-2.14$ (m, 1H), 1.94 (d, J=12.3 Hz, 1H), 1.74 (dddd, $J$ $=13.8,10.5,7.9,1.6 \mathrm{~Hz}, 1 \mathrm{H}) .{ }^{13} \mathbf{C}$ NMR $\left(100 \mathrm{MHz}, \mathrm{CDCl}_{3}\right) \delta 209.95,134.77,133.49,129.91,129.10$, $128.77,127.79,80.64,75.20,55.67,34.61,33.30,32.03$. IR $\left(\mathrm{KBr}, \mathrm{cm}^{-1}\right) 2952,1710,1491,1088,1012$, 980. HRMS calcd $\mathrm{C}_{15} \mathrm{H}_{15} \mathrm{ClO}_{2}[\mathrm{M}+\mathrm{H}]^{+}: 263.0833$. Found: 263.0838 .

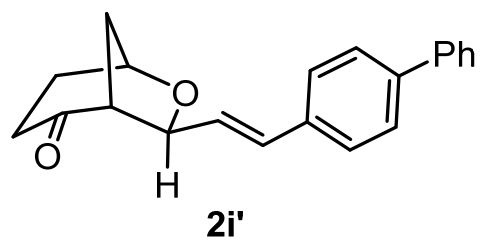

exo-7-((E)-2-([1,1'-Biphenyl]-4-yl)vinyl)-6-oxabicyclo[3.2.1]octan-2-one (2i'): Synthesized from 1k according to "standard conditions B" . 61\% yield; exo:endo = 9:1; yellow solid; M.p. $80-82{ }^{\circ} \mathrm{C} ; \mathrm{R}_{f}=$ 0.35 (hexane/EtOAc = 3:1). ${ }^{1} \mathbf{H}$ NMR $\left(400 \mathrm{MHz}, \mathrm{CDCl}_{3}\right) \delta 7.65$ - $7.52(\mathrm{~m}, 4 \mathrm{H}), 7.49-7.39(\mathrm{~m}, 4 \mathrm{H}), 7.39$ - 7.30 (m, 1H), 6.69 (dd, $J=15.7,1.4 \mathrm{~Hz}, 1 \mathrm{H}), 6.16(\mathrm{dd}, J=15.7,5.5 \mathrm{~Hz}, 1 \mathrm{H}), 4.81$ (dd, $J=5.6,1.4 \mathrm{~Hz}$, $1 \mathrm{H}), 4.71(\mathrm{td}, J=3.9,2.0 \mathrm{~Hz}, 1 \mathrm{H}), 2.87-2.79(\mathrm{~m}, 1 \mathrm{H}), 2.71-2.54(\mathrm{~m}, 1 \mathrm{H}), 2.49-2.35(\mathrm{~m}, 2 \mathrm{H}), 2.24$ (ddd, $J=11.8,6.6,2.2 \mathrm{~Hz}, 1 \mathrm{H}), 1.95$ (d, $J=12.3 \mathrm{~Hz}, 1 \mathrm{H}), 1.75$ (dddd, $J=13.7,10.5,7.8,1.6 \mathrm{~Hz}, 1 \mathrm{H}$ ). ${ }^{13}$ C NMR $\left(100 \mathrm{MHz}, \mathrm{CDCl}_{3}\right) \delta 210.18,140.63,140.59,135.30,130.66,128.81,128.51,127.39,127.31$, 127.03, 126.95, 80.86, 75.18, 55.80, 34.68, 33.37, 32.11. IR (KBr, cm $\left.{ }^{-1}\right) 2924,1708,1461,1275,1261$, 1087. HRMS calcd. $\mathrm{C}_{21} \mathrm{H}_{21} \mathrm{O}_{2}[\mathrm{M}+\mathrm{H}]^{+}: 305.1536$. Found: 305.1540 .

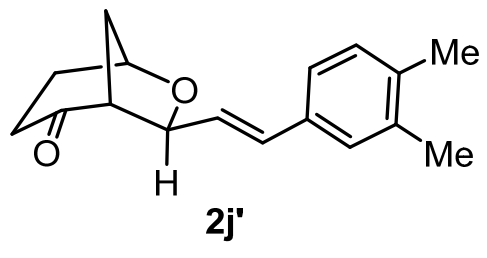

7-((E)-3,4-Dimethylstyryl)-6-oxabicyclo[3.2.1]octan-2-one (2j): Synthesized from 11 according to “standard conditions B". $63 \%$ yield; exo:endo $=8: 1$; pale oil; $\mathrm{R}_{f}=0.35$ (hexane/EtOAc $=3: 1$ ). ${ }^{1} \mathbf{H}$ 
NMR $\left(400 \mathrm{MHz}, \mathrm{CDCl}_{3}\right) \delta 7.19-7.02(\mathrm{~m}, 3 \mathrm{H}), 6.58(\mathrm{dd}, J=15.7,1.4 \mathrm{~Hz}, 1 \mathrm{H}), 6.05(\mathrm{dd}, J=15.7,5.7$ $\mathrm{Hz}, 1 \mathrm{H}), 4.76(\mathrm{dd}, J=5.8,1.4 \mathrm{~Hz}, 1 \mathrm{H}), 4.68(\mathrm{td}, J=4.1,3.7,2.1 \mathrm{~Hz}, 1 \mathrm{H}), 2.80(\mathrm{~d}, J=5.0 \mathrm{~Hz}, 1 \mathrm{H}), 2.62$ (ddd, $J=17.0,10.4,9.4 \mathrm{~Hz}, 1 \mathrm{H}), 2.49-2.34(\mathrm{~m}, 1 \mathrm{H}), 2.25(\mathrm{~m}, 7 \mathrm{H}), 1.92(\mathrm{~d}, J=12.3 \mathrm{~Hz}, 1 \mathrm{H}), 1.82$ - 1.66 $(\mathrm{m}, 1 \mathrm{H}) .{ }^{13} \mathbf{C}$ NMR $\left(100 \mathrm{MHz}, \mathrm{CDCl}_{3}\right) \delta 210.27,136.72,136.46,133.91,131.14,129.86,127.83,127.19$, 124.07, 81.02, 75.07, 55.88, 34.68, 33.41, 32.13, 19.78, 19.55. IR (KBr, cm $\left.{ }^{-1}\right) 2946,1711,1445,1225$, 1089, 1065, 979. HRMS calcd $\mathrm{C}_{17} \mathrm{H}_{21} \mathrm{O}_{2}[\mathrm{M}+\mathrm{H}]^{+}:$257.1536. Found: 257.1545.

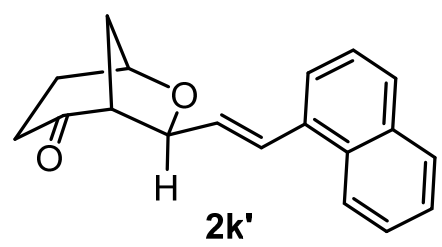

exo-7-((E)-2-(Naphthalen-1-yl)vinyl)-6-oxabicyclo[3.2.1]octan-2-one (2k'): Synthesized from 1m according to "standard conditions B". $61 \%$ yield; exo:endo $=14: 1$; yellow oil; $\mathrm{R}_{f}=0.4$ (hexane/EtOAc = 3:1). ${ }^{1} \mathbf{H}$ NMR $\left(400 \mathrm{MHz}, \mathrm{CDCl}_{3}\right) \delta 8.16-8.07(\mathrm{~m}, 1 \mathrm{H}), 7.87(\mathrm{dd}, J=7.1,2.5 \mathrm{~Hz}, 1 \mathrm{H}), 7.81(\mathrm{dt}, J=8.1$, $1.1 \mathrm{~Hz}, 1 \mathrm{H}), 7.62-7.51(\mathrm{~m}, 3 \mathrm{H}), 7.49-7.38(\mathrm{~m}, 2 \mathrm{H}), 6.17(\mathrm{dd}, J=15.4,5.5 \mathrm{~Hz}, 1 \mathrm{H}), 4.93(\mathrm{dd}, J=5.4$, $1.5 \mathrm{~Hz}, 1 \mathrm{H}), 4.79(\mathrm{ddd}, J=5.3,3.7,1.3 \mathrm{~Hz}, 1 \mathrm{H}), 2.98-2.81(\mathrm{~m}, 1 \mathrm{H}), 2.78-2.64(\mathrm{~m}, 1 \mathrm{H}), 2.54-2.40(\mathrm{~m}$, 2H), $2.36-2.24(\mathrm{~m}, 1 \mathrm{H}), 2.01(\mathrm{~d}, J=12.3 \mathrm{~Hz}, 1 \mathrm{H}), 1.80$ (dddd, $J=13.8,10.5,7.8,1.6 \mathrm{~Hz}, 1 \mathrm{H}) .{ }^{13} \mathbf{C}$ NMR $\left(100 \mathrm{MHz}, \mathrm{CDCl}_{3}\right) \delta 210.18,134.12,133.59,131.70,131.13,128.55,128.51,128.19,126.14$, $125.86,125.56,123.95,123.74,80.97,75.22,55.79,34.71,33.39,32.13$. IR $\left(\mathrm{KBr}, \mathrm{cm}^{-1}\right) 3004,1713$, 1445, 1394, 1226, 1149. HRMS calcd. $\mathrm{C}_{19} \mathrm{H}_{19} \mathrm{O}_{2}[\mathrm{M}+\mathrm{H}]^{+}:$279.1380. Found: 279.1376.

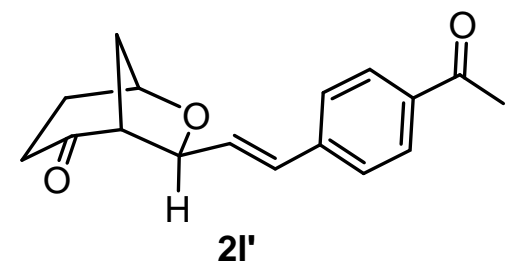

exo-7-((E)-4-Acetylstyryl)-6-oxabicyclo[3.2.1]octan-2-one (2l'): Synthesized from 1n according to “standard conditions B". $59 \%$ yield; exo:endo $=11: 1$; yellow oil; $\mathrm{R}_{f}=0.45$ (hexane/EtOAc $=3: 1$ ). ${ }^{1}$ H NMR (400 MHz, $\left.\mathrm{CDCl}_{3}\right) \delta 7.96-7.80(\mathrm{~m}, 2 \mathrm{H}), 7.48-7.35(\mathrm{~m}, 2 \mathrm{H}), 6.69$ (dd, $\left.J=15.7,1.5 \mathrm{~Hz}, 0 \mathrm{H}\right)$, $6.24(\mathrm{dd}, J=15.8,5.3 \mathrm{~Hz}, 0 \mathrm{H}), 4.80(\mathrm{dd}, J=5.3,1.5 \mathrm{~Hz}, 1 \mathrm{H}), 4.71(\mathrm{ddd}, J=5.6,3.7,1.4 \mathrm{~Hz}, 1 \mathrm{H}), 2.82(\mathrm{~d}$, $J=4.8 \mathrm{~Hz}, 1 \mathrm{H}), 2.59(\mathrm{~m}, 4 \mathrm{H}), 2.49-2.32(\mathrm{~m}, 2 \mathrm{H}), 2.30-2.14(\mathrm{~m}, 1 \mathrm{H}), 1.95(\mathrm{~d}, J=12.3 \mathrm{~Hz}, 1 \mathrm{H}), 1.75$ (dddd, $J=13.8,10.5,7.8,1.6 \mathrm{~Hz}, 1 \mathrm{H}) .{ }^{13} \mathbf{C} \mathbf{~ N M R}\left(100 \mathrm{MHz}, \mathrm{CDCl}_{3}\right) \delta 209.80,197.49,140.89,136.25$, $131.40,130.05,128.78,126.66,80.52,75.29,55.56,34.60,33.26,32.01,26.62 . \mathbf{I R}\left(\mathrm{KBr}, \mathrm{cm}^{-1}\right) 3005$, 1711, 1680, 1275, 1261, 1065. HRMS calcd $\mathrm{C}_{17} \mathrm{H}_{19} \mathrm{O}_{3}[\mathrm{M}+\mathrm{H}]^{+}:$271.1329. Found: 271.1339. 


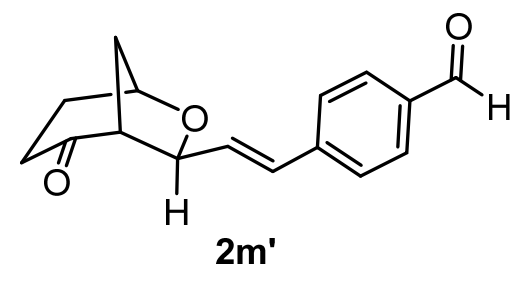

exo-4-((E)-2-Oxo-6-oxabicyclo[3.2.1]octan-7-yl)vinyl)benzaldehyde (2m'): Synthesized from 10 according to "standard conditions B". $55 \%$ yield; exo:endo $=13: 1$; yellow oil; $\mathrm{R}_{f}=0.35$ (hexane/EtOAc = 3:1). ${ }^{1} \mathbf{H}$ NMR $\left(400 \mathrm{MHz}, \mathrm{CDCl}_{3}\right) \delta 9.97(\mathrm{~s}, 1 \mathrm{H}), 7.83(\mathrm{~d}, J=8.3 \mathrm{~Hz}, 2 \mathrm{H}), 7.51$ (d, $J=$ $8.3 \mathrm{~Hz}, 2 \mathrm{H}), 6.71(\mathrm{dd}, J=15.8,1.5 \mathrm{~Hz}, 1 \mathrm{H}), 6.27(\mathrm{dd}, J=15.8,5.2 \mathrm{~Hz}, 1 \mathrm{H}), 4.80(\mathrm{dd}, J=5.2,1.6 \mathrm{~Hz}$, $1 \mathrm{H}), 4.71$ (ddd, $J=5.5,3.7,1.4 \mathrm{~Hz}, 1 \mathrm{H}), 2.82(\mathrm{~d}, J=4.7 \mathrm{~Hz}, 1 \mathrm{H}), 2.62(\mathrm{ddd}, J=17.0,10.4,9.4 \mathrm{~Hz}, 1 \mathrm{H})$, 2.48 - $2.31(\mathrm{~m}, 2 \mathrm{H}), 2.29-2.17(\mathrm{~m}, 1 \mathrm{H}), 1.95(\mathrm{~d}, J=12.3 \mathrm{~Hz}, 1 \mathrm{H}), 1.75(\mathrm{dddd}, J=13.7,10.5,7.8,1.6 \mathrm{~Hz}$, 1H). ${ }^{13} \mathbf{C}$ NMR $\left(100 \mathrm{MHz}, \mathrm{CDCl}_{3}\right) \delta 209.74,191.65,142.28,135.58,132.18,130.16,129.95,127.09$, 80.44, 75.33, 55.51, 34.59, 33.24, 31.99. IR (KBr, cm $\left.{ }^{-1}\right)$ 2953, 1697, 1603, 1214, 1167, 1088. HRMS calcd $\mathrm{C}_{16} \mathrm{H}_{17} \mathrm{O}_{3}[\mathrm{M}+\mathrm{H}]^{+}: 257.1172$. Found: 257.1182 .

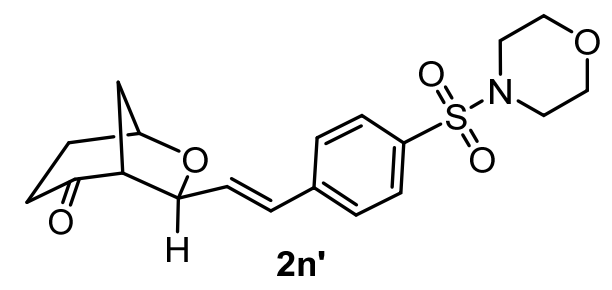

exo-7-((E)-4-(Morpholinosulfonyl)styryl)-6-oxabicyclo[3.2.1]octan-2-one (2n'): Synthesized from 1q according "standard conditions B". $39 \%$ yield; exo:endo $=10: 1$; yellow oil; $\mathrm{R}_{f}=0.2$ (hexane/EtOAc = 1:1). ${ }^{1} \mathbf{H}$ NMR $\left(400 \mathrm{MHz}, \mathrm{CDCl}_{3}\right) \delta 7.70(\mathrm{~d}, \mathrm{~J}=8.5 \mathrm{~Hz}, 2 \mathrm{H}), 7.52(\mathrm{~d}, \mathrm{~J}=8.3 \mathrm{~Hz}, 2 \mathrm{H})$, $6.71(\mathrm{dd}, J=15.8,1.5 \mathrm{~Hz}, 1 \mathrm{H}), 6.26(\mathrm{dd}, J=15.7,5.0 \mathrm{~Hz}, 1 \mathrm{H}), 4.81(\mathrm{dd}, J=5.1,1.6 \mathrm{~Hz}, 1 \mathrm{H}), 4.72(\mathrm{t}, J=$ $4.6 \mathrm{~Hz}, 1 \mathrm{H}), 3.88-3.68(\mathrm{~m}, 4 \mathrm{H}), 3.03-2.96(\mathrm{~m}, 4 \mathrm{H}), 2.83(\mathrm{~d}, J=4.7 \mathrm{~Hz}, 1 \mathrm{H}), 2.63(\mathrm{dt}, J=16.9,10.0 \mathrm{~Hz}$, $1 \mathrm{H}), 2.49-2.30(\mathrm{~m}, 2 \mathrm{H}), 2.24(\mathrm{t}, J=12.1 \mathrm{~Hz}, 1 \mathrm{H}), 1.96(\mathrm{~d}, J=12.3 \mathrm{~Hz}, 1 \mathrm{H}), 1.76(\mathrm{dddd}, J=13.7,10.4$, 7.9, $1.6 \mathrm{~Hz}, 1 \mathrm{H}) .{ }^{13} \mathbf{C}$ NMR $\left(100 \mathrm{MHz}, \mathrm{CDCl}_{3}\right) \delta 209.65,141.09,133.86,132.46,129.26,128.27,127.07$, 80.30, 75.37, 66.10, 55.48, 45.99, 34.58, 33.19, 31.97. IR (KBr, $\left.\mathrm{cm}^{-1}\right)$ 2858, 1712, 1348, 1166, 1113, 944 , 741. HRMS calcd $\mathrm{C}_{19} \mathrm{H}_{24} \mathrm{NO}_{5} \mathrm{~S}[\mathrm{M}+\mathrm{H}]^{+}: 378.1370$. Found: 378.1375 .

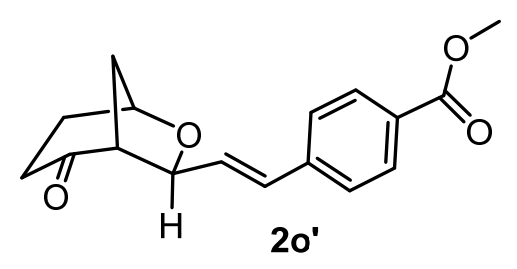


exo-Methyl 4-((E)-2-xo-6-oxabicyclo[3.2.1]octan-7-yl)vinyl)benzoate (2o'): Synthesized from 1r according “standard conditions B". $42 \%$ yield; exo:endo $=10: 1$; pale oil; $\mathrm{R}_{f}=0.2$ (hexane/EtOAc = 3:1). ${ }^{1} \mathbf{H}$ NMR $\left(400 \mathrm{MHz}, \mathrm{CDCl}_{3}\right) \delta 8.09-7.80(\mathrm{~m}, 2 \mathrm{H}), 7.42(\mathrm{~d}, J=8.2 \mathrm{~Hz}, 2 \mathrm{H}), 6.69(\mathrm{dd}, J=15.7$, $1.5 \mathrm{~Hz}, 1 \mathrm{H}), 6.22(\mathrm{dd}, J=15.7,5.3 \mathrm{~Hz}, 2 \mathrm{H}), 4.79(\mathrm{dd}, J=5.3,1.5 \mathrm{~Hz}, 1 \mathrm{H}), 4.71$ (ddd, $J=5.6,3.8,1.4 \mathrm{~Hz}$, $1 \mathrm{H}), 3.91(\mathrm{~s}, 3 \mathrm{H}), 2.82(\mathrm{~d}, J=4.7 \mathrm{~Hz}, 1 \mathrm{H}), 2.68-2.54(\mathrm{~m}, 1 \mathrm{H}), 2.48-2.32(\mathrm{~m}, 2 \mathrm{H}), 2.28-2.16(\mathrm{~m}, 1 \mathrm{H})$, $1.94(\mathrm{~d}, J=12.3 \mathrm{~Hz}, 1 \mathrm{H}), 1.75$ (dddd, $J=13.8,10.5,7.9,1.6 \mathrm{~Hz}, 1 \mathrm{H}) .{ }^{13} \mathbf{C} \mathbf{N M R}\left(100 \mathrm{MHz}, \mathrm{CDCl}_{3}\right) \delta$ 209.82, 166.79, 140.72, 131.16, 130.14, 129.96, 129.27, 126.47, 80.53, 75.27, 55.58, 52.11, 34.61, 33.27, 32.02. IR $\left(\mathrm{KBr}, \mathrm{cm}^{-1}\right)$ 2989, 1723, 1607, 1276, 1267. HRMS calcd $\mathrm{C}_{17} \mathrm{H}_{19} \mathrm{O}_{4}[\mathrm{M}+\mathrm{H}]^{+}: 287.1278$. Found: 287.1285 .

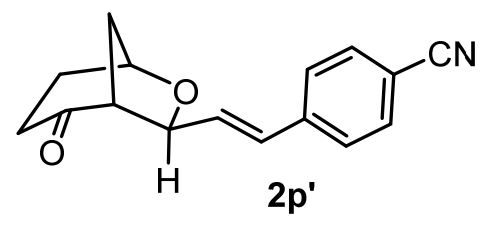

exo-4-((E)-2-Oxo-6-oxabicyclo[3.2.1]octan-7-yl)vinyl)benzonitrile (2p'): Synthesized from $1 \mathrm{~s}$ according to “standard conditions B". $43 \%$ yield; exo:endo $=10: 1$; pale oil; $\mathrm{R}_{f}=0.20$ (hexane/EtOAc = 3:1). ${ }^{1} \mathbf{H}$ NMR $\left(400 \mathrm{MHz}, \mathrm{CDCl}_{3}\right) \delta 7.60(\mathrm{~d}, J=8.4 \mathrm{~Hz}, 2 \mathrm{H}), 7.44(\mathrm{~d}, J=8.3 \mathrm{~Hz}, 2 \mathrm{H}), 6.67(\mathrm{dd}, J=$ 15.8, 1.6 Hz, 1H), $6.24(\mathrm{dd}, J=15.8,5.1 \mathrm{~Hz}, 1 \mathrm{H}), 4.80(\mathrm{dd}, J=5.1,1.6 \mathrm{~Hz}, 1 \mathrm{H}), 4.71(\mathrm{ddd}, J=5.6,3.9$, $1.4 \mathrm{~Hz}, 1 \mathrm{H}), 2.81(\mathrm{~d}, J=4.8 \mathrm{~Hz}, 1 \mathrm{H}), 2.62(\mathrm{dt}, J=17.0,9.9 \mathrm{~Hz}, 1 \mathrm{H}), 2.48-2.31(\mathrm{~m}, 3 \mathrm{H}), 2.23(\mathrm{dd}, J=$ 13.2, $9.8 \mathrm{~Hz}, 1 \mathrm{H}), 1.95(\mathrm{~d}, J=12.3 \mathrm{~Hz}, 1 \mathrm{H}), 1.76(\mathrm{dddd}, J=13.8,10.4,7.8,1.6 \mathrm{~Hz}, 1 \mathrm{H}) .{ }^{13} \mathbf{C} \mathbf{N M R}(100$ $\left.\mathrm{MHz}, \mathrm{CDCl}_{3}\right) \delta 209.60,140.74,132.48,132.46,129.41,127.07,118.84,111.10,80.28,75.37,55.45$, 34.56, 33.19, 31.95. IR $\left(\mathrm{KBr}, \mathrm{cm}^{-1}\right) 2988,2226,1717,1605,1275,1261$. HRMS calcd $\mathrm{C}_{16} \mathrm{H}_{17} \mathrm{O}_{3}[\mathrm{M}+\mathrm{H}]^{+}$: 254.1176. Found: 254.1186.

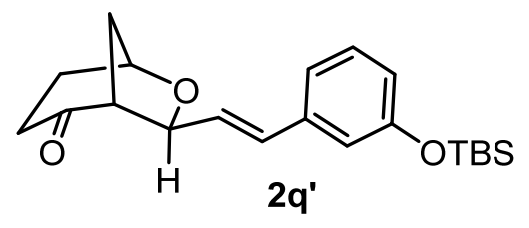

exo-7-((E)-3-((tert-Butyldimethylsilyl)oxy)styryl)-6-oxabicyclo[3.2.1]octan-2-one

(2q'):

Synthesized from 1t according to “standard conditions B". $50 \%$ yield; exo:endo =10:1; pale oil; $\mathrm{R}_{f}=$ 0.35 (hexane/EtOAc = 3:1). ${ }^{1} \mathbf{H}$ NMR $\left(400 \mathrm{MHz}, \mathrm{CDCl}_{3}\right) \delta 7.16(\mathrm{t}, J=7.9 \mathrm{~Hz}, 1 \mathrm{H}), 6.96(\mathrm{dt}, J=7.8,1.1$ $\mathrm{Hz}, 1 \mathrm{H}), 6.83$ (t, $J=2.0 \mathrm{~Hz}, 1 \mathrm{H}), 6.73$ (ddd, $J=8.1,2.4,1.0 \mathrm{~Hz}, 1 \mathrm{H}), 6.58(\mathrm{dd}, J=15.8,1.5 \mathrm{~Hz}, 1 \mathrm{H})$, $6.06(\mathrm{dd}, J=15.7,5.5 \mathrm{~Hz}, 1 \mathrm{H}), 4.77(\mathrm{dd}, J=5.4,1.5 \mathrm{~Hz}, 1 \mathrm{H}), 4.69$ (t, $J=4.4 \mathrm{~Hz}, 1 \mathrm{H}), 2.81$ (d, $J=4.8 \mathrm{~Hz}$, 1H), $2.62(\mathrm{ddd}, J=16.9,10.1,9.3 \mathrm{~Hz}, 1 \mathrm{H}), 2.48-2.33(\mathrm{~m}, 2 \mathrm{H}), 2.22(\mathrm{dd}, J=13.3,9.8 \mathrm{~Hz}, 1 \mathrm{H}), 1.93(\mathrm{~d}$, 
$J=12.3 \mathrm{~Hz}, 1 \mathrm{H}), 1.74(\mathrm{dddd}, J=13.7,10.6,7.8,1.6 \mathrm{~Hz}, 1 \mathrm{H}), 0.98(\mathrm{~s}, 9 \mathrm{H}), 0.20(\mathrm{~s}, 6 \mathrm{H}) .{ }^{13} \mathbf{C}$ NMR $(100$ $\left.\mathrm{MHz}, \mathrm{CDCl}_{3}\right) \delta 210.15,155.89,137.76,130.95,129.49,128.52,119.75,119.59,118.19,80.77,75.14$, 55.75, 34.64, 33.32, 32.08, 25.70, 18.21, 15.30, -4.37. IR (KBr, cm $\left.{ }^{-1}\right)$ 2955, 1714, 1578, 1472, 1277, 974, 860. HRMS calcd $\mathrm{C}_{21} \mathrm{H}_{31} \mathrm{O}_{3} \mathrm{Si}[\mathrm{M}+\mathrm{H}]^{+}:$359.2037. Found: 359.2039.

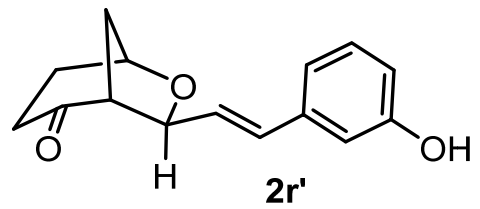

exo-7-((E)-3-Hydroxystyryl)-6-oxabicyclo[3.2.1]octan-2-one (2r'): Synthesized from $1 \mathbf{u}$ according to “standard conditions B”. $32 \%$ yield; exo:endo $=4: 1$; pale oil; $\mathrm{R}_{f}=0.35$ (hexane/EtOAc $\left.=1: 1\right) .{ }^{1} \mathbf{H}$ NMR $\left(400 \mathrm{MHz}, \mathrm{CDCl}_{3}\right) \delta 7.18(\mathrm{t}, J=7.8 \mathrm{~Hz}, 1 \mathrm{H}), 6.94(\mathrm{dt}, J=7.7,1.3 \mathrm{~Hz}, 1 \mathrm{H}), 6.84(\mathrm{dd}, J=2.6,1.6 \mathrm{~Hz}, 1 \mathrm{H})$, $6.73(\mathrm{ddd}, J=8.0,2.6,0.9 \mathrm{~Hz}, 1 \mathrm{H}), 6.58(\mathrm{dd}, J=15.7,1.4 \mathrm{~Hz}, 1 \mathrm{H}), 6.08$ (dd, $J=15.7,5.5 \mathrm{~Hz}, 1 \mathrm{H}), 5.00$ (s, 1H), $4.77(\mathrm{dd}, J=5.6,1.5 \mathrm{~Hz}, 1 \mathrm{H}), 4.70$ (t, $J=4.5 \mathrm{~Hz}, 1 \mathrm{H}), 2.80$ (d, $J=4.7 \mathrm{~Hz}, 1 \mathrm{H}), 2.62$ (ddd, $J=$ 17.0, 10.2, $9.3 \mathrm{~Hz}, 1 \mathrm{H}), 2.48-2.30(\mathrm{~m}, 2 \mathrm{H}), 2.29-2.08$ (m, 1H), 1.93 (d, $J=12.3 \mathrm{~Hz}, 1 \mathrm{H}), 1.74$ (dddd, $J$ $=13.7,10.5,7.8,1.6 \mathrm{~Hz}, 1 \mathrm{H}) .{ }^{13} \mathbf{C}$ NMR $\left(100 \mathrm{MHz}, \mathrm{CDCl}_{3}\right) \delta 210.26,155.80,137.99,130.76,129.83$, $128.85, \quad 119.36, \quad 114.93, \quad 113.21,80.72,75.19, \quad 55.71,34.64,33.30,32.05$. IR $\left(\mathrm{KBr}, \mathrm{cm}^{-1}\right)$ 3005, 2989, 1710, 1583, 1452, 1090. HRMS calcd. $\mathrm{C}_{15} \mathrm{H}_{17} \mathrm{O}_{3}[\mathrm{M}+\mathrm{H}]^{+}: 245.1172$. Found: 245.1181 .

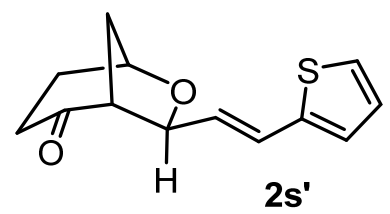

exo-7-((E)-2-(Thiophen-2-yl)vinyl)-6-oxabicyclo[3.2.1]octan-2-one (2s'): Synthesized from 1v according to "standard conditions B". $45 \%$ yield; exo:endo $=8: 1$; yellow oil; $\mathrm{R}_{f}=0.35$ (hexane/EtOAc = 3:1). ${ }^{1} \mathbf{H}$ NMR (400 MHz, $\left.\mathrm{CDCl}_{3}\right) \delta 7.21-7.10(\mathrm{~m}, 1 \mathrm{H}), 7.03-6.89(\mathrm{~m}, 2 \mathrm{H}), 6.77(\mathrm{ddd}, J=15.5,1.5$, $0.8 \mathrm{~Hz}, 1 \mathrm{H}), 5.94(\mathrm{dd}, J=15.5,5.4 \mathrm{~Hz}, 1 \mathrm{H}), 4.73(\mathrm{dd}, J=5.5,1.5 \mathrm{~Hz}, 1 \mathrm{H}), 4.68$ (ddd, $J=5.6,3.9,1.3 \mathrm{~Hz}$, 1H), $2.86-2.75(\mathrm{~m}, 1 \mathrm{H}), 2.60(\mathrm{ddd}, J=17.0,10.6,9.7 \mathrm{~Hz}, 1 \mathrm{H}), 2.48-2.30(\mathrm{~m}, 2 \mathrm{H}), 2.28-2.13(\mathrm{~m}, 1 \mathrm{H})$, $1.92(\mathrm{~d}, J=12.4 \mathrm{~Hz}, 1 \mathrm{H}), 1.73$ (dddd, $J=13.7,10.5,7.8,1.6 \mathrm{~Hz}, 1 \mathrm{H}) .{ }^{13} \mathbf{C} \mathbf{N M R}\left(100 \mathrm{MHz}, \mathrm{CDCl}_{3}\right) \delta$ $210.00,141.40,127.96,127.42,126.23,124.61,124.27,80.46,75.15,55.69,34.63,33.30$, 32.05. IR $\left(\mathrm{KBr}, \mathrm{cm}^{-1}\right) 3290,2936,1726,1453,1366,1085$. HRMS calcd. $\mathrm{C}_{13} \mathrm{H}_{15} \mathrm{O}_{2} \mathrm{~S}[\mathrm{M}+\mathrm{H}]^{+}:$235.0787. Found: 235.0782 .

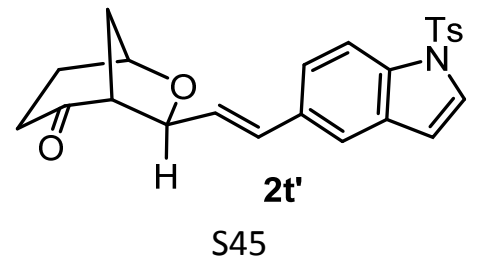


exo-7-((E)-2-(1-Tosyl-1H-indol-5-yl)vinyl)-6-oxabicyclo[3.2.1]octan-2-one (2t'): Synthesized from 1w according to "standard conditions B". $35 \%$ yield; exo:endo $=11: 1$; yellow oil; $\mathrm{R}_{f}=0.35$ (hexane/EtOAc = 2:1). ${ }^{1} \mathbf{H}$ NMR $\left(400 \mathrm{MHz}, \mathrm{CDCl}_{3}\right) \delta 7.92(\mathrm{~d}, J=8.6 \mathrm{~Hz}, 1 \mathrm{H}), 7.83-7.69(\mathrm{~m}, 2 \mathrm{H}), 7.53$ $(\mathrm{d}, J=3.7 \mathrm{~Hz}, 1 \mathrm{H}), 7.48(\mathrm{~d}, J=1.6 \mathrm{~Hz}, 1 \mathrm{H}), 7.35(\mathrm{dd}, J=8.7,1.7 \mathrm{~Hz}, 1 \mathrm{H}), 7.24-7.14(\mathrm{~m}, 2 \mathrm{H}), 6.68$ (dd, $J=15.7,1.5 \mathrm{~Hz}, 1 \mathrm{H}), 6.61(\mathrm{dd}, J=3.7,0.8 \mathrm{~Hz}, 1 \mathrm{H}), 6.07(\mathrm{dd}, J=15.7,5.6 \mathrm{~Hz}, 1 \mathrm{H}), 4.77$ (dd, $J=5.6,1.4$ $\mathrm{Hz}, 1 \mathrm{H}), 4.69$ (t, $J=4.7 \mathrm{~Hz}, 1 \mathrm{H}), 2.80$ (d, $J=4.7 \mathrm{~Hz}, 1 \mathrm{H}), 2.62(\mathrm{ddd}, J=17.0,10.3,9.3 \mathrm{~Hz}, 1 \mathrm{H}), 2.49$ $2.34(\mathrm{~m}, 2 \mathrm{H}), 2.33(\mathrm{~s}, 3 \mathrm{H}), 2.27-2.13(\mathrm{~m}, 1 \mathrm{H}), 1.93(\mathrm{~d}, J=12.3 \mathrm{~Hz}, 1 \mathrm{H}), 1.74(\mathrm{dddd}, J=13.7,10.5,7.8$, $1.6 \mathrm{~Hz}, 1 \mathrm{H}) .{ }^{13} \mathbf{C}$ NMR $\left(100 \mathrm{MHz}, \mathrm{CDCl}_{3}\right) \delta 210.15,145.01,135.20,134.44,131.80,131.13,131.07$, $129.89,127.83$, 126.97, 126.78, 123.11, 119.64, 113.65, 109.14, 80.88, 75.13, 55.84, 34.65, 33.36, 32.08, 21.58. IR $\left(\mathrm{KBr}, \mathrm{cm}^{-1}\right) 2952,1714,1288,1277,974,860$. HRMS calcd $\mathrm{C}_{24} \mathrm{H}_{24} \mathrm{NO}_{4} \mathrm{~S}[\mathrm{M}+\mathrm{H}]^{+}: 422.1421$. Found: 422.1429.

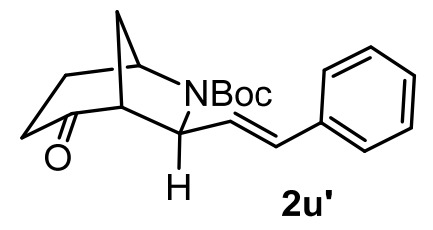

exo-tert-Butyl-2-oxo-7-((E)-styryl)-6-azabicyclo[3.2.1]octane-6-carboxylate (2u'): Synthesized from 1aa according to "standard conditions B". $42 \%$ yield; exo: endo $=2.3: 1$; pale oil; $\mathrm{R}_{f}=0.4$ (hexane/EtOAc $=3: 1) .{ }^{1} \mathbf{H}$ NMR $\left(400 \mathrm{MHz}, \mathrm{CDCl}_{3}\right)$ (mixture of rotamers) $\delta 7.40-7.28(\mathrm{~m}, 5 \mathrm{H}), 6.51$ (ddd, $J=18.8,15.6,1.2 \mathrm{~Hz}, 1 \mathrm{H}), 6.07$ (ddd, $J=19.7,15.7,6.1 \mathrm{~Hz}, 1 \mathrm{H}), 4.54-4.38$ (m, 1H), 4.37 - 4.26 (m, 1H), $2.74(\mathrm{~d}, J=4.3 \mathrm{~Hz}, 1 \mathrm{H}), 2.51-2.32(\mathrm{~m}, 4 \mathrm{H}), 1.84(\mathrm{dd}, J=12.4,2.0 \mathrm{~Hz}, 1 \mathrm{H}), 1.77$ - $1.62(\mathrm{~m}, 1 \mathrm{H})$, $1.46(\mathrm{~d}, J=34.9 \mathrm{~Hz}, 2 \mathrm{H}) .{ }^{13} \mathbf{C}$ NMR $\left(101 \mathrm{MHz}, \mathrm{CDCl}_{3}\right) \delta 209.90,209.45,153.85,136.43,136.37,131.52$, $131.39,131.16,128.68,128.47,128.36,128.33$, 128.28, 127.80, 127.67, 127.43, 127.03, 126.62, 126.38, $80.66,80.14,80.07,61.93,61.55,55.76,55.01,54.17,53.59,40.14,34.88,33.50,32.51,30.26,29.82$, 28.91, 28.53, 28.47, 28.42. IR $\left(\mathrm{KBr}, \mathrm{cm}^{-1}\right)$ 2971, 1692, 1388, 1366, 1166, 1116. HRMS calcd. $\mathrm{C}_{20} \mathrm{H}_{26} \mathrm{NO}_{3}$ $[\mathrm{M}+\mathrm{H}]^{+}:$328.1907. Found: 328.1900 .
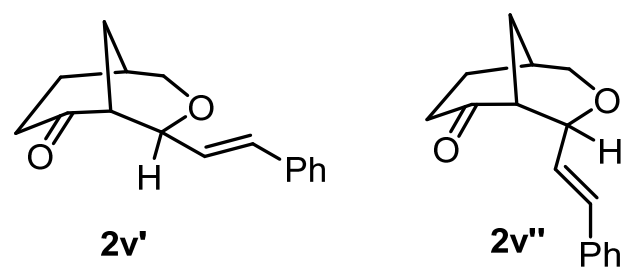

4-Styryl-3-oxabicyclo [3.3.1]nonan-6-one (2v'): Synthesized from 1a according to "standard conditions B”.64\% yield; exo:endo $=1.3: 1$. The exo/endo structures of the two products are determined by coupling constant analysis from the ${ }^{1} \mathrm{H}$ NMR with COSY analysis of $\mathbf{2} \mathbf{v}^{\prime}$ (vide infra). (exo-2v'): pale oil; $\mathrm{R}_{f}=0.45$ (hexane/EtOAc = 3:1). ${ }^{1} \mathbf{H}$ NMR $\left(400 \mathrm{MHz}, \mathrm{CDCl}_{3}\right) \delta 7.43$ - 7.39 (m, 2H), 7.37 - 7.32 (m, 2H), $\mathrm{S} 46$ 
$7.30-7.25(\mathrm{~m}, 1 \mathrm{H}), 6.66(\mathrm{dd}, J=16.2,1.9 \mathrm{~Hz}, 1 \mathrm{H}), 6.32(\mathrm{dd}, J=16.2,4.5 \mathrm{~Hz}, 1 \mathrm{H}), 4.52(\mathrm{dd}, J=4.4,2.0$ $\mathrm{Hz}, 1 \mathrm{H}), 4.22(\mathrm{dt}, J=11.6,2.2 \mathrm{~Hz}, 1 \mathrm{H}), 3.83(\mathrm{dt}, J=11.5,2.0 \mathrm{~Hz}, 1 \mathrm{H}), 3.06$ (ddd, $J=16.4,11.7,8.6 \mathrm{~Hz}$, $1 \mathrm{H}), 2.58-2.54(\mathrm{~m}, 1 \mathrm{H}), 2.56(\mathrm{br}, 1 \mathrm{H}), 2.33(\mathrm{dq}, J=13.6,3.3,2.6 \mathrm{~Hz}, 1 \mathrm{H}), 2.15$ (ddt, $J=11.1,7.0,2.4$ $\mathrm{Hz}, 1 \mathrm{H}), 2.02(\mathrm{ddtd}, J=13.8,6.8,4.8,2.1 \mathrm{~Hz}, 1 \mathrm{H}), 1.91-1.81(\mathrm{~m}, 2 \mathrm{H}) .{ }^{13} \mathbf{C}$ NMR $\left(100 \mathrm{MHz}, \mathrm{CDCl}_{3}\right) \delta$ 213.53, 136.44, 132.80, 128.67, 127.94, 126.45, 126.32, 74.03, 67.76, 50.17, 39.83, 29.70, 28.40, 26.54.

IR $\left(\mathrm{KBr}, \mathrm{cm}^{-1}\right)$ 2925, 1708, 1494, 1449, 1230, 1120. HRMS calcd. $\mathrm{C}_{16} \mathrm{H}_{19} \mathrm{O}_{2}[\mathrm{M}+\mathrm{H}]^{+}: 243.1380$. Found: 243.1383. (endo-2v'"): pale oil; $\mathrm{R}_{f}=0.35$ (Hexane/EtOAc $\left.=3: 1\right) .{ }^{1} \mathbf{H}$ NMR $\left(400 \mathrm{MHz}, \mathrm{CDCl}_{3}\right) \delta 7.37$ $7.31(\mathrm{~m}, 2 \mathrm{H}), 7.30$ - $7.26(\mathrm{~m}, 2 \mathrm{H}), 7.23-7.18(\mathrm{~m}, 1 \mathrm{H}), 6.62(\mathrm{dd}, J=15.9,1.6 \mathrm{~Hz}, 1 \mathrm{H}), 6.04$ (dd, $J=15.9$, $5.3 \mathrm{~Hz}, 1 \mathrm{H}), 4.32(\mathrm{dt}, J=5.3,2.0 \mathrm{~Hz}, 1 \mathrm{H}), 4.21(\mathrm{dt}, J=11.3,2.1 \mathrm{~Hz}, 1 \mathrm{H}), 4.02(\mathrm{dt}, J=11.3,2.3 \mathrm{~Hz}, 1 \mathrm{H})$, 2.84 (ddd, $J=15.9,12.4,8.6 \mathrm{~Hz}, 1 \mathrm{H}), 2.58$ (br, 1H), 2.48 (dd, $J=15.9,6.9 \mathrm{~Hz}, 1 \mathrm{H}), 2.28-2.06$ (m, 3H), $2.04-1.93(\mathrm{~m}, 1 \mathrm{H}), 1.89(\mathrm{~m}, 1 \mathrm{H}) .{ }^{13} \mathbf{C}$ NMR $\left(101 \mathrm{MHz}, \mathrm{CDCl}_{3}\right) \delta 211.82,136.47,130.96,128.44,127.71$, $127.15,126.65,78.07,73.83,51.82,41.45,33.08,30.36,28.28$. IR $\left(\mathrm{KBr}, \mathrm{cm}^{-1}\right) 2929,1708,1449,1198$, 1123, 1036. HRMS calcd. $\mathrm{C}_{16} \mathrm{H}_{19} \mathrm{O}_{2}[\mathrm{M}+\mathrm{H}]^{+}: 243.1380$. Found: 243.1386.

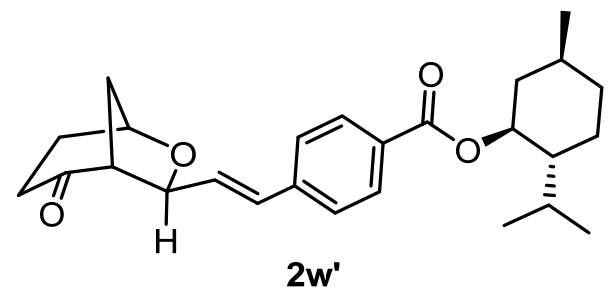

exo-7-((E)-3-((tert-Butyldimethylsilyl)oxy)styryl)-6-oxabicyclo[3.2.1]octan-2-one (2w'): Synthesized from 1ac according to "standard conditions B". $59 \%$ yield; exo:endo $=10: 1$; pale oil; $\mathrm{R}_{f}=0.3$ (hexane/EtOAc = 3:1). ${ }^{1} \mathbf{H}$ NMR $\left(400 \mathrm{MHz}, \mathrm{CDCl}_{3}\right) \delta 8.03(\mathrm{q}, J=1.7 \mathrm{~Hz}, 1 \mathrm{H}), 7.91(\mathrm{dq}, J=7.7,1.3 \mathrm{~Hz}$, 1H), 7.53 (dt, $J=7.8,1.6 \mathrm{~Hz}, 1 \mathrm{H}), 7.38$ (t, $J=7.7 \mathrm{~Hz}, 1 \mathrm{H}), 6.69$ (dd, $J=15.8,1.4 \mathrm{~Hz}, 1 \mathrm{H}), 6.19$ (dd, $J=$ 15.7, $5.4 \mathrm{~Hz}, 1 \mathrm{H}), 4.94(\mathrm{td}, J=10.9,4.4 \mathrm{~Hz}, 1 \mathrm{H}), 4.79(\mathrm{dd}, J=5.4,1.5 \mathrm{~Hz}, 1 \mathrm{H}), 4.71(\mathrm{t}, J=4.7 \mathrm{~Hz}, 1 \mathrm{H})$, $2.82(\mathrm{~d}, J=4.7 \mathrm{~Hz}, 1 \mathrm{H}), 2.63(\mathrm{dt}, J=17.0,9.9 \mathrm{~Hz}, 1 \mathrm{H}), 2.49-2.34(\mathrm{~m}, 2 \mathrm{H}), 2.29-2.18(\mathrm{~m}, 1 \mathrm{H}), 2.16$ $2.04(\mathrm{~m}, 1 \mathrm{H}), 2.01-1.86(\mathrm{~m}, 2 \mathrm{H}), 1.82-1.69(\mathrm{~m}, 3 \mathrm{H}), 1.65-1.47(\mathrm{~m}, 2 \mathrm{H}), 1.12(\mathrm{tt}, J=12.1,10.3 \mathrm{~Hz}$, $2 \mathrm{H}), 0.92(\mathrm{dd}, J=6.8,4.7 \mathrm{~Hz}, 7 \mathrm{H}), 0.79(\mathrm{dd}, J=7.0,1.2 \mathrm{~Hz}, 3 \mathrm{H}) .{ }^{13} \mathbf{C}$ NMR $\left(100 \mathrm{MHz}, \mathrm{CDCl}_{3}\right) \delta 209.96$, $165.92,136.57,131.26,130.69,130.22,129.70,128.80,128.62,127.60,80.62,75.21,74.99,55.66,47.26$, 40.97, 34.63, 34.32, 33.30, 32.06, 31.47, 26.51, 23.63, 22.07, 20.80, 16.52. IR (KBr, cm $\left.{ }^{-1}\right) 2955,1713$, 1290, 1197, 1109, 1065, 983. HRMS calcd $\mathrm{C}_{26} \mathrm{H}_{35} \mathrm{O}_{4}[\mathrm{M}+\mathrm{H}]^{+}:$411.2530. Found: 411.2529. 


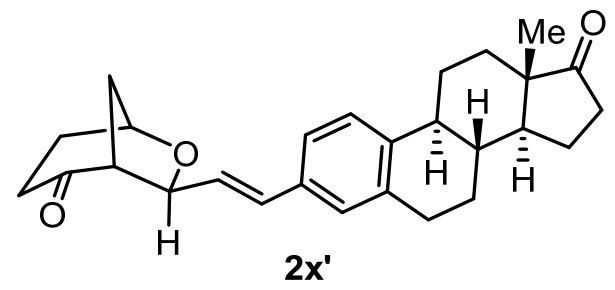

exo-7-((E)-2-((8R,9S,13S)-13-Methyl-17-oxo-7,8,9,11,12,13,14,15,16,17-decahydro-6Hcyclopenta[a]phenanthren-3-yl)vinyl)-6-oxabicyclo[3.2.1]octan-2-one (2x'): Synthesized from 1a according to "standard conditions B". 57 \% yield; exo:endo = 12:1; yellow solid; M.p. 104-106 ${ }^{\circ}$; $\mathrm{R}_{f}=0.3$ (hexane/EtOAc = 3:1). ${ }^{1} \mathbf{H}$ NMR $\left(400 \mathrm{MHz}, \mathrm{CDCl}_{3}\right) \delta 7.26-7.24(\mathrm{~m}, 1 \mathrm{H}), 7.17(\mathrm{dd}, J=8.2,1.9$ $\mathrm{Hz}, 1 \mathrm{H}), 7.11(\mathrm{~d}, J=1.4 \mathrm{~Hz}, 1 \mathrm{H}), 6.59(\mathrm{dd}, J=15.7,1.3 \mathrm{~Hz}, 1 \mathrm{H}), 6.07$ (dd, $J=15.7,5.6 \mathrm{~Hz}, 1 \mathrm{H}), 4.77$ $(\mathrm{dd}, J=5.7,1.4 \mathrm{~Hz}, 1 \mathrm{H}), 4.68(\mathrm{td}, J=4.2,2.1 \mathrm{~Hz}, 1 \mathrm{H}), 2.91(\mathrm{dd}, J=9.0,4.3 \mathrm{~Hz}, 2 \mathrm{H}), 2.79(\mathrm{~d}, J=4.7 \mathrm{~Hz}$, 1H), 2.68 - $2.46(\mathrm{~m}, 3 \mathrm{H}), 2.45-1.89(\mathrm{~m}, 11 \mathrm{H}), 1.79-1.59(\mathrm{~m}, 3 \mathrm{H}), 1.56-1.40(\mathrm{~m}, 4 \mathrm{H}), 0.91(\mathrm{~s}, 3 \mathrm{H}) .{ }^{13} \mathbf{C}$ NMR $\left(100 \mathrm{MHz}, \mathrm{CDCl}_{3}\right) \delta 220.82,210.20,139.66,136.70,133.88,130.84,127.81,127.21,125.65$, 124.01, 80.95, 75.11, 55.86, 50.50, 47.98, 44.45, 38.14, 35.86, 34.66, 33.37, 32.11, 31.58, 29.37, 26.47, 25.72, 21.60, 13.85. IR $\left(\mathrm{KBr}, \mathrm{cm}^{-1}\right) 2931,1736,1715,1276,1261,1065$. HRMS calcd $\mathrm{C}_{27} \mathrm{H}_{33} \mathrm{O}_{3}[\mathrm{M}+\mathrm{H}]^{+}$: 405.2424. Found: 405.2417. 
The enantiomeric excess of compound 2a obtained by using (-)-DIOP as the ligand was tested by chiral HPLC (Chiralpak ID, Hexane:isopropanol $=98: 2,1 \mathrm{~mL} / \mathrm{min}, 254 \mathrm{~nm}$ ), $t_{\text {major }}=26.371$ $\min , t_{\text {minor }}=49.495 \mathrm{~min}$. at $11 \%$ ee.

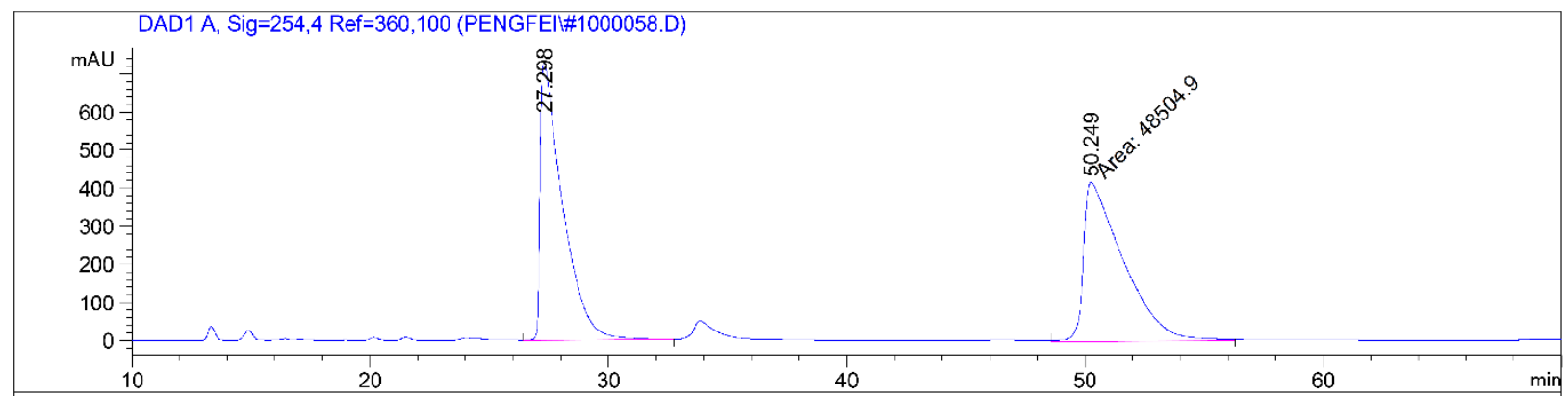

$\underline{\text { Racemic 2a }}$

Signal 1: DAD1 A, Sig=254, 4 Ref=360,100

\begin{tabular}{|c|c|c|c|c|c|c|}
\hline $\begin{array}{c}\text { Peak } \\
\quad \#\end{array}$ & $\begin{array}{c}\text { RetTime } \\
\text { [min] }\end{array}$ & Type & $\begin{array}{l}\text { Width } \\
\text { [min] }\end{array}$ & $\begin{array}{c}\text { Area } \\
{\left[\mathrm{mAU}{ }^{\star} \mathrm{s}\right]}\end{array}$ & $\begin{array}{l}\text { Height } \\
\text { [mAU] }\end{array}$ & $\begin{array}{c}\text { Area } \\
\quad \%\end{array}$ \\
\hline & & & 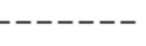 & --ー--ー-- & --ー--ー-- & ---- \\
\hline 1 & 27.298 & $\mathrm{BB}$ & 0.8993 & $4.74478 e 4$ & 730.94922 & 49.4492 \\
\hline 2 & 50.249 & MM & 1.9359 & 4.85049 e 4 & 417.59756 & 50.5508 \\
\hline
\end{tabular}

Enantiomeric 2a'

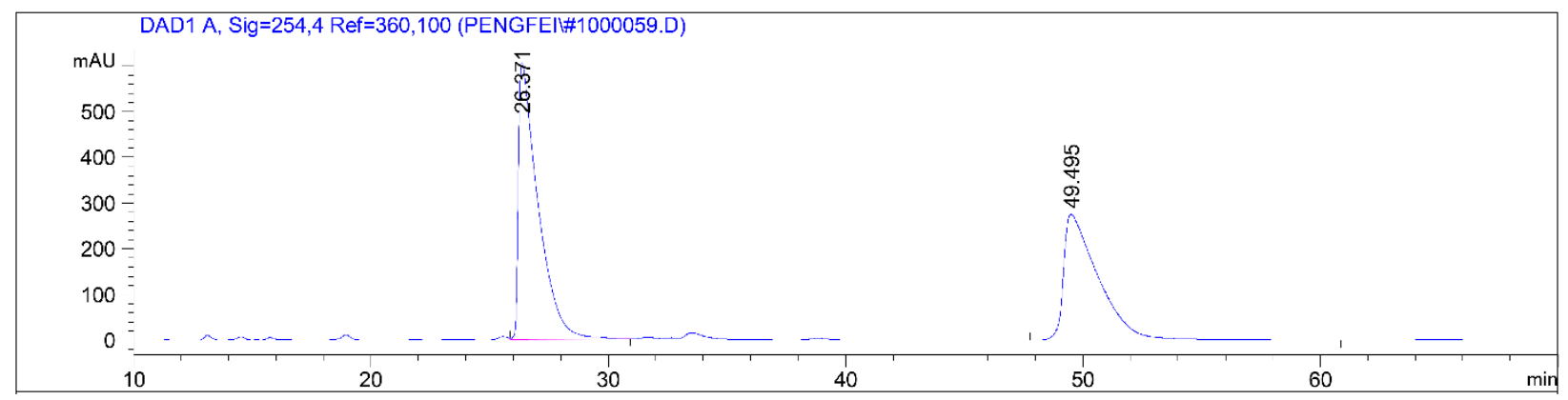


Signal 1: DAD1 A, Sig=254,4 Ref=360,100

\begin{tabular}{|c|c|c|c|c|c|c|}
\hline $\begin{array}{c}\text { eak } \\
\text { \# }\end{array}$ & $\begin{array}{l}\text { RetTime } \\
\text { [min] }\end{array}$ & Type & $\begin{array}{l}\text { Width } \\
\text { [min] }\end{array}$ & $\begin{array}{c}\text { Area } \\
{\left[\mathrm{mAU}{ }^{*} \mathrm{~s}\right]}\end{array}$ & $\begin{array}{l}\text { Height } \\
\text { [mAU] }\end{array}$ & $\begin{array}{c}\text { Area } \\
\frac{\circ}{0}\end{array}$ \\
\hline & & & & & --- & --- \\
\hline 1 & 26.3 & $\mathrm{VB}$ & & 3.487 & 605 & 137 \\
\hline 2 & 49.495 & $\mathrm{BB}$ & 1.4340 & $2.78380 e^{4}$ & 274.77145 & 44.3863 \\
\hline
\end{tabular}

VI. Derivatization of the cyclohexanone $\alpha$-allylic alkylation [3.2.1] bicycles

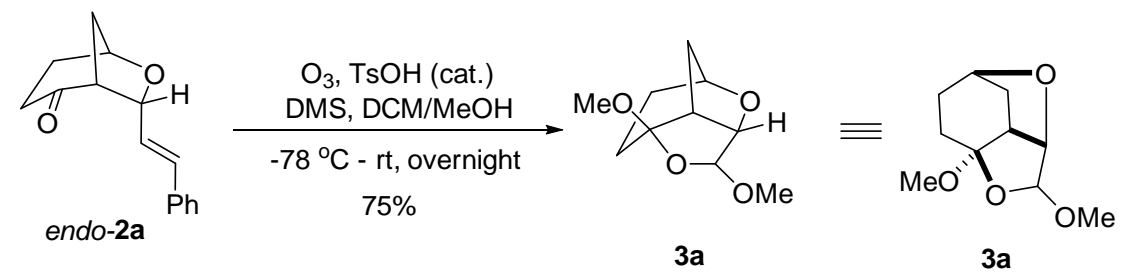

endo-2,7-Dimethoxyoctahydro-3,5-epoxybenzofuran (3a): Following a modified procedure from literature, ${ }^{5}$ a flow of $\mathrm{O}_{3} / \mathrm{O}_{2}$, generated from a regular ozone generator, passed through a MeOH/DCM solution $(1: 1,12 \mathrm{~mL})$ of endo-2a $(0.2 \mathrm{mmol}, 45.6 \mathrm{mg})$ and $p-\mathrm{TsOH} \cdot \mathrm{H}_{2} \mathrm{O}(4 \mathrm{mg})$ at $-78{ }^{\circ} \mathrm{C}$ for several minutes until the red color (sudan red III as indicator) disappeared. A flow of $\mathrm{N}_{2}$ passed though the solution for 2 minutes. Dimethyl sulfide $(0.8 \mathrm{~mL})$ was added and the solution allowed to warm to room temperature and stirred overnight. The reaction was concentrated and purified by column chromatography over silica gel (hexane:EtOAc $=8: 1)$ to yield the desired 3a as a colorless oil in $75 \%$ yield $(30 \mathrm{mg}) . \mathrm{R}_{f}=$ 0.55 (hexane/EtOAc = 3:1). ${ }^{1} \mathbf{H}$ NMR $\left(400 \mathrm{MHz}, \mathrm{CDCl}_{3}\right) \delta 4.82(\mathrm{~d}, J=0.7 \mathrm{~Hz}, 1 \mathrm{H}), 4.33(\mathrm{t}, J=5.4 \mathrm{~Hz}$, $1 \mathrm{H}), 4.15(\mathrm{~d}, J=4.1 \mathrm{~Hz}, 1 \mathrm{H}), 3.42(\mathrm{~s}, 3 \mathrm{H}), 3.36(\mathrm{~s}, 3 \mathrm{H}), 2.99-2.80(\mathrm{~m}, 1 \mathrm{H}), 1.93-1.88(\mathrm{~m}, 1 \mathrm{H}), 1.86(\mathrm{dq}$, $J=2.2,0.8 \mathrm{~Hz}, 1 \mathrm{H}), 1.83(\mathrm{ddd}, J=5.3,3.8,1.4 \mathrm{~Hz}, 1 \mathrm{H}), 1.80-1.76(\mathrm{~m}, 1 \mathrm{H}), 1.76-1.71(\mathrm{~m}, 1 \mathrm{H}), 1.58$ $1.46(\mathrm{~m}, 1 \mathrm{H}), 1.38(\mathrm{ddd}, J=13.5,11.3,8.4 \mathrm{~Hz}, 1 \mathrm{H}) .{ }^{13} \mathbf{C} \mathbf{N M R}\left(101 \mathrm{MHz}, \mathrm{CDCl}_{3}\right) \delta 113.47,106.49$, 85.08, 74.66, 54.97, 49.45, 44.86, 29.75, 28.18, 26.87. IR (KBr, $\left.\mathrm{cm}^{-1}\right) 3005,2988,1755,1462,1454$, 1179. HRMS calcd $\mathrm{C}_{10} \mathrm{H}_{17} \mathrm{O}_{4}[\mathrm{M}+\mathrm{H}]^{+}:$201.1121. Found: 201.1113.

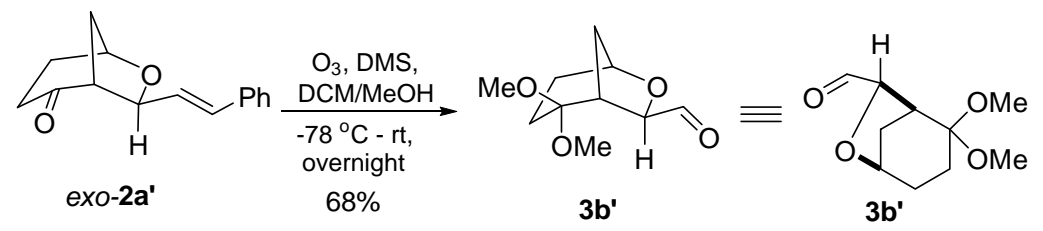

endo-2,2-Dimethoxy-6-oxabicyclo[3.2.1]octane-7-carbaldehyde (3b'): Following a modified procedure from literature. ${ }^{5}$ a flow of $\mathrm{O}_{3} / \mathrm{O}_{2}$, generated from a regular ozone generator, passed through a $\mathrm{MeOH} / \mathrm{DCM}$ solution $(1: 1,12 \mathrm{~mL})$ of exo-2a' $(0.2 \mathrm{mmol}, 45.6 \mathrm{mg})$ at $-78{ }^{\circ} \mathrm{C}$ for several minutes until the red color disappeared. A flow of $\mathrm{N}_{2}$ passed though the solution for 2 minutes. Dimethyl sulfide $(0.8 \mathrm{~mL})$ 
was added and the solution allowed to warm to room temperature and stirred overnight. The reaction was concentrated and purified by column chromatography over silica gel (hexane:EtOAc $=8: 1$ ) to yield the desired $\mathbf{3 b}$ ' as a colorless oil in $68 \%$ yield $(27 \mathrm{mg}) . \mathrm{R}_{f}=0.50$ (hexane/EtOAc $\left.=3: 1\right) .{ }^{1} \mathbf{H}$ NMR (400

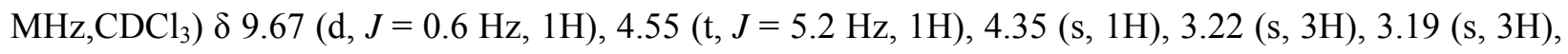
$2.81(\mathrm{dd}, J=5.2,2.0 \mathrm{~Hz}, 1 \mathrm{H}), 1.93(\mathrm{ddt}, J=13.5,5.9,1.6 \mathrm{~Hz}, 1 \mathrm{H}), 1.89$ - $1.78(\mathrm{~m}, 2 \mathrm{H}), 1.66$ - $1.54(\mathrm{~m}$, 2H), 1.52 - 1.39 (m, 1H). ${ }^{13} \mathbf{C}$ NMR (101 MHz, $\left.\mathrm{CDCl}_{3}\right) \delta$ 202.80, 100.59, 84.43, 76.62, 47.94, 47.87, 44.03, 31.77, 29.42, 27.99. IR $\left(\mathrm{KBr}, \mathrm{cm}^{-1}\right) 3004,2988,1731,1462,1366,1112$. HRMS calcd $\mathrm{C}_{10} \mathrm{H}_{17} \mathrm{O}_{4}$ $[\mathrm{M}+\mathrm{H}]^{+}:$201.1121. Found: 201.1130.

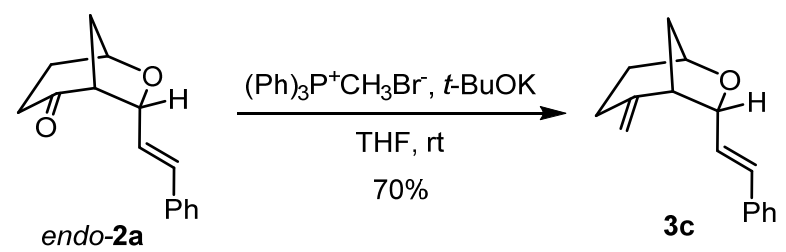

endo-2-Methylene-7-((E)-styryl)-6-oxabicyclo[3.2.1]octane (3c): Following a procedure from literature. ${ }^{6} t$-BuOK (34 mg, $0.3 \mathrm{mmol}$ ) was added in one portion to a suspension of endo-2a (22.8 $\mathrm{mg}, 0.1 \mathrm{mmol})$ and methyltriphenylphosphonium bromide (108 $\mathrm{mg}, 0.3 \mathrm{mmol})$ in THF (4.0 $\mathrm{mL}$ ). The reaction mixture was stirred at room temperature for $36 \mathrm{~h}$. Upon completion, the crude mixture was carefully quenched with $\mathrm{NH}_{4} \mathrm{Cl}(20 \mathrm{~mL})$, extracted with EtOAc $(10 \mathrm{~mL}$ x 3). The combined organic fractions were dried over $\mathrm{MgSO}_{4}$, filtered and concentrated. The residue was purified by column chromatography over silica gel (hexane:EtOAc $=8: 1$ ) to yield the desired $\mathbf{3 c}$ as a colorless oil in $70 \%$ yield (16 mg). $\mathbf{R}_{f}=0.7$ (hexane/EtOAc = 3:1). ${ }^{1} \mathbf{H}$ NMR $\left(400 \mathrm{MHz}, \mathrm{CDCl}_{3}\right) \delta 7.43-7.35(\mathrm{~m}, 2 \mathrm{H}), 7.34$ $7.27(\mathrm{~m}, 2 \mathrm{H}), 7.24-7.18(\mathrm{~m}, 1 \mathrm{H}), 6.70(\mathrm{dd}, J=15.9,1.3 \mathrm{~Hz}, 1 \mathrm{H}), 6.29(\mathrm{dd}, J=15.8,6.5 \mathrm{~Hz}, 1 \mathrm{H}), 4.70(\mathrm{t}$, $J=2.3 \mathrm{~Hz}, 1 \mathrm{H}), 4.66(\mathrm{t}, J=2.4 \mathrm{~Hz}, 1 \mathrm{H}), 4.62(\mathrm{ddd}, J=6.5,3.7,1.4 \mathrm{~Hz}, 1 \mathrm{H}), 4.52(\mathrm{dd}, J=6.0,4.5 \mathrm{~Hz}$, $1 \mathrm{H}), 2.88(\mathrm{t}, J=4.1 \mathrm{~Hz}, 1 \mathrm{H}), 2.61-2.45(\mathrm{~m}, 1 \mathrm{H}), 2.33-2.20(\mathrm{~m}, 2 \mathrm{H}), 2.01-1.86(\mathrm{~m}, 1 \mathrm{H}), 1.76(\mathrm{dd}, J=$ $11.1,1.0 \mathrm{~Hz}, 1 \mathrm{H}), 1.47$ (dddd, $J=12.9,11.4,7.0,1.0 \mathrm{~Hz}, 1 \mathrm{H}) .{ }^{13} \mathbf{C} \mathbf{N M R}\left(100 \mathrm{MHz}, \mathrm{CDCl}_{3}\right) \delta 147.26$, $137.04,132.29,128.47,127.48,126.73,126.55,109.17,82.83,75.66,49.03,39.48,32.46$, 27.90. IR $\left(\mathrm{KBr}, \mathrm{cm}^{-1}\right) 3300,2934,1605,1494,1309,1173$. HRMS calcd $\mathrm{C}_{16} \mathrm{H}_{19} \mathrm{O}[\mathrm{M}+\mathrm{H}]^{+}:$227.1430. Found: 227.1420 .

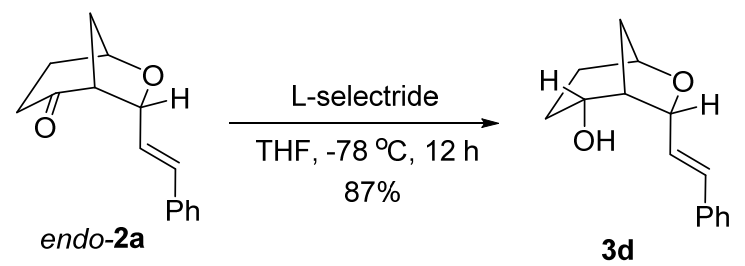

endo-7-((E)-Styryl)-6-oxabicyclo[3.2.1] 0 octan-2-ol (3d): Following a procedure from literature, ${ }^{7}$ endo-2a (114 mg, $0.5 \mathrm{mmol})$ was dissolved in freshly distilled THF $(3 \mathrm{~mL})$ under argon and cooled to $-78{ }^{\circ} \mathrm{C}$. L- 
Selectride $(1.0 \mathrm{ml}, 1.0 \mathrm{M}$ in THF, $1.0 \mathrm{mmol})$ was added dropwise, and the resulting mixture was stirred overnight. Then acetone $(1 \mathrm{~mL})$ was added, followed by $\mathrm{H}_{2} \mathrm{O}_{2}(1 \mathrm{~mL}, 30 \%)$. The reaction mixture was stirred for another $1 \mathrm{~h}$ and warmed to room temperature continually. $\mathrm{H}_{2} \mathrm{O}(10 \mathrm{~mL})$ and $\mathrm{CH}_{2} \mathrm{Cl}_{2}(10 \mathrm{ml})$ were added and the layers were separated. The aqueous phase was extracted with $\mathrm{CH}_{2} \mathrm{Cl}_{2}(10 \mathrm{~mL} \times 3)$. The combined organic solutions were dried over $\mathrm{Na}_{2} \mathrm{SO}_{4}$. The solvent was removed in vacuo. The residue was purified (hexane:EtOAc $=3: 1)$ to yield the desired $\mathbf{3 d}$ as a white solid in $87 \%$ yield $(100 \mathrm{mg})$. The diastereoselectivity is determined by COSY and NOESY analysis (vide infra). $\mathrm{R}_{f}=0.35$ (hexane/EtOAc $=$ 3:1). ${ }^{1} \mathbf{H}$ NMR $\left(400 \mathrm{MHz}, \mathrm{CDCl}_{3}\right) \delta 7.44-7.38(\mathrm{~m}, 2 \mathrm{H}), 7.32(\mathrm{dd}, J=8.3,6.7 \mathrm{~Hz}, 2 \mathrm{H}), 7.26-7.20(\mathrm{~m}$, $1 \mathrm{H}), 6.78(\mathrm{dd}, J=16.1,1.4 \mathrm{~Hz}, 1 \mathrm{H}), 6.69(\mathrm{dd}, J=16.0,5.4 \mathrm{~Hz}, 1 \mathrm{H}), 4.88-4.66(\mathrm{~m}, 1 \mathrm{H}), 4.43(\mathrm{dd}, J=6.2$, $3.9 \mathrm{~Hz}, 1 \mathrm{H}), 3.89$ (d, $J=7.9 \mathrm{~Hz}, 1 \mathrm{H}), 2.54$ (q, $J=4.0 \mathrm{~Hz}, 1 \mathrm{H}), 2.27-2.14(\mathrm{~m}, 1 \mathrm{H}), 2.05-1.89(\mathrm{~m}, 3 \mathrm{H})$, $1.60(\mathrm{~d}, J=11.6 \mathrm{~Hz}, 1 \mathrm{H}), 1.55(\mathrm{~d}, J=6.9 \mathrm{~Hz}, 1 \mathrm{H}), 1.42(\mathrm{tdd}, J=10.0,8.2,2.9 \mathrm{~Hz}, 1 \mathrm{H}) .{ }^{13} \mathbf{C} \mathbf{~ N M R}(101$ $\left.\mathrm{MHz}, \mathrm{CDCl}_{3}\right) \delta 136.80,130.93,128.59,127.54,127.14,126.45,82.52,75.00,72.47,46.43,37.39,31.37$, 29.19. IR $\left(\mathrm{KBr}, \mathrm{cm}^{-1}\right) 3404,2939,1493,1330,1082,1055$. HRMS calcd $\mathrm{C}_{15} \mathrm{H}_{19} \mathrm{O}_{2}[\mathrm{M}+\mathrm{H}]^{+}: 231.1380$. Found: 231.1377.

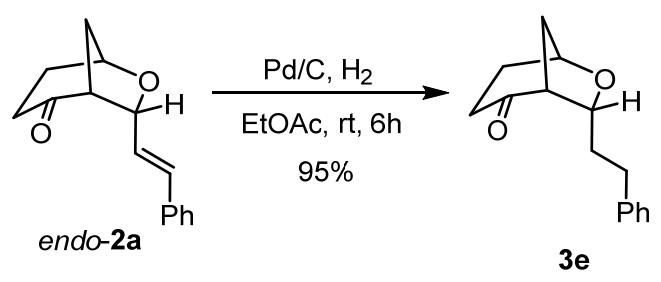

endo-7-Phenethyl-6-oxabicyclo[3.2.1] ]octan-2-one (3e): The $4 \mathrm{~mL}$ vial was charged with $\mathrm{Pd} / \mathrm{C}(10 \%$ w/w, $80 \mathrm{mg})$. After degassed, EtOAc $(1 \mathrm{~mL})$ was carefully added, and endo-2a (45.6 mg, $0.2 \mathrm{mmol})$ dissolved in EtOAc $(2 \mathrm{~mL})$ was slightly added to the mixture. The reaction was stirred under $\mathrm{H}_{2}$ balloon pressure at room temperature for $6 \mathrm{~h}$. After completion, the reaction mixture was filtered through a short plug of celite and concentrated under vacue. The residue was purified by column chromatography (hexane:EtOAc $=5: 1$ ) to yield the desired $3 \mathbf{e}$ as a colorless oil in $95 \%$ yield $(43.7 \mathrm{mg}) . \mathrm{R}_{f}=0.55$ (hexane:EtOAc = 3:1). ${ }^{1} \mathbf{H}$ NMR $\left(400 \mathrm{MHz}, \mathrm{CDCl}_{3}\right) \delta 7.32$ - $7.24(\mathrm{~m}, 2 \mathrm{H}), 7.22$ - $7.15(\mathrm{~m}, 3 \mathrm{H}), 4.56$ (ddd, $J=5.7,3.5,1.8 \mathrm{~Hz}, 1 \mathrm{H}), 4.04$ (ddd $J=8.0,6.2,3.8 \mathrm{~Hz}, 1 \mathrm{H}), 2.81$ (t, $J=4.0 \mathrm{~Hz}, 1 \mathrm{H}), 2.79$ - $2.63(\mathrm{~m}, 2 \mathrm{H})$, $2.48-2.30(\mathrm{~m}, 3 \mathrm{H}), 2.10(\mathrm{ddq}, J=14.7,9.0,3.1 \mathrm{~Hz}, 1 \mathrm{H}), 2.01$ (d, $J=12.2 \mathrm{~Hz}, 1 \mathrm{H}), 1.90$ (dddd, $J=13.9$, 9.5, 8.0, 6.0 Hz, 1H), 1.81 - $1.62(\mathrm{~m}, 2 \mathrm{H}) .{ }^{13} \mathbf{C}$ NMR (100 MHz, $\left.\mathrm{CDCl}_{3}\right) \delta$ 210.30, 141.23, 128.42, 128.39, 125.99, 81.02, 74.17, 53.89, 35.41, 35.20, 33.04, 32.63, 30.76. IR (KBr, cm $\left.{ }^{-1}\right) 3026,2927,2861,1713$, 1496, 1454. HRMS calcd $\mathrm{C}_{15} \mathrm{H}_{19} \mathrm{O}_{2}[\mathrm{M}+\mathrm{H}]^{+}: 231.1380$. Found: 231.1370. 


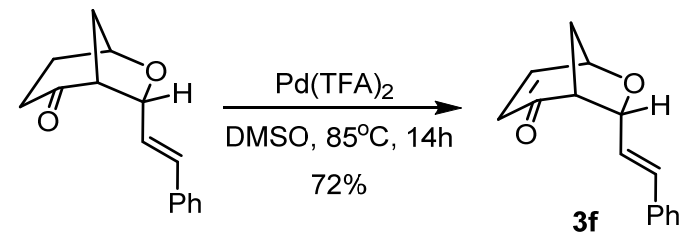

endo-7-((E)-Styryl)-6-oxabicyclo[3.2.1]oct-3-en-2-one (3f): Following a modified procedure from literature, ${ }^{8}$ the $4 \mathrm{~mL}$ vial was charged with $\operatorname{Pd}(\mathrm{TFA})_{2}(33 \mathrm{mg}, 0.1 \mathrm{mmol})$ and endo-2a $(22.8 \mathrm{mg}, 0.1$ mmol) in DMSO $(1 \mathrm{~mL})$. The reaction mixture was stirred at $85{ }^{\circ} \mathrm{C}$ for $14 \mathrm{~h}$. After completion, the reaction mixture was filtered through a short plug of celite and concentrated under vacue. The residue was purified by column chromatography (hexane:EtOAc $=5: 1$ ) to yield the desired $\mathbf{3 f}$ as a yellow oil in $72 \%$ yield $(16.3 \mathrm{mg}) . R_{f}=0.45$ (hexane/EtOAc $\left.=3: 1\right) .{ }^{1} \mathbf{H} \mathbf{~ N M R}\left(400 \mathrm{MHz}, \mathrm{CDCl}_{3}\right) \delta 7.41(\mathrm{ddd}, J=9.5,5.6$, $1.3 \mathrm{~Hz}, 1 \mathrm{H}), 7.32-7.27(\mathrm{~m}, 4 \mathrm{H}), 7.26-7.17(\mathrm{~m}, 1 \mathrm{H}), 6.61(\mathrm{dd}, J=15.8,1.5 \mathrm{~Hz}, 1 \mathrm{H}), 6.06(\mathrm{ddd}, J=9.5$, 1.6, $1.0 \mathrm{~Hz}, 1 \mathrm{H}), 5.94(\mathrm{dd}, J=15.7,6.6 \mathrm{~Hz}, 1 \mathrm{H}), 4.96(\mathrm{ddd}, J=6.5,4.9,1.4 \mathrm{~Hz}, 1 \mathrm{H}), 4.73$ (t, $J=5.2 \mathrm{~Hz}$, $1 \mathrm{H}), 3.39$ (tdt, $J=5.1,1.8,1.0 \mathrm{~Hz}, 1 \mathrm{H}), 2.47-2.23(\mathrm{~m}, 2 \mathrm{H}) .{ }^{13} \mathbf{C}$ NMR $\left(100 \mathrm{MHz}, \mathrm{CDCl}_{3}\right) \delta 199.57$, $152.53,136.26,132.81,131.65,128.45,127.83,126.71,126.27,79.10,72.46,56.91,40.47 . \mathbf{I R}\left(\mathrm{KBr}, \mathrm{cm}^{-}\right.$ $\left.{ }^{1}\right) 2931,1736,1716,1276,1261,1065$. HRMS calcd $\mathrm{C}_{15} \mathrm{H}_{15} \mathrm{O}^{2}[\mathrm{M}+\mathrm{H}]^{+}: 227.1067$. Found: 227.1068 .

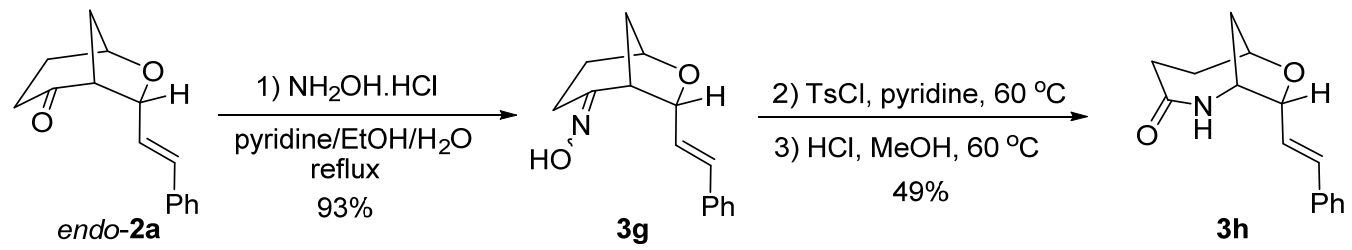

endo-7-((E)-Styryl)-6-oxabicyclo[3.2.1]octan-2-one oxime (3g): Following a modified procedure from literature ${ }^{6}$ hydroxylamine hydrochloride $(105 \mathrm{mg}, 1.50 \mathrm{mmol})$ was added in one portion to a solution of endo-2a (45.6 mg, $0.2 \mathrm{mmol})$ in pyridine/EtOH/water $=6 / 3 / 3(12 \mathrm{~mL})$. The reaction mixture was heated to reflux for 24 hours. Then, the reaction was quenched with saturated $\mathrm{NH}_{4} \mathrm{Cl}$ solution $(25 \mathrm{~mL})$. The aqueous phase was extracted with EtOAc $(20 \mathrm{~mL} \times 2)$ and the combined organic extracts were dried over $\mathrm{MgSO}_{4}$, filtered and concentrated under vacue. The residue was purified by column chromatography (hexane:EtOAc $=4: 1$ ) to yield the desired $3 \mathrm{~g}$ as a white solid $95 \%$ yield $\left(46 \mathrm{mg}\right.$ ). M.p. $100-102{ }^{\circ} \mathrm{C} . \mathrm{R}_{f}=$ 0.3 (hexane/EtOAc = 3:1). ${ }^{1} \mathbf{H}$ NMR $\left(400 \mathrm{MHz}, \mathrm{CDCl}_{3}\right) \delta 8.57(\mathrm{br}, 1 \mathrm{H}), 7.36(\mathrm{ddd}, J=8.0,3.4,1.4 \mathrm{~Hz}$, 2H), 7.28 (ddt, $J=7.7,6.0,1.6 \mathrm{~Hz}, 2 \mathrm{H}), 7.25-7.16(\mathrm{~m}, 1 \mathrm{H}), 6.71(\mathrm{ddd}, J=16.0,5.1,1.5 \mathrm{~Hz}, 1 \mathrm{H}), 6.25$ (dd, $J=16.0,5.4 \mathrm{~Hz}, 0.22 \mathrm{H}), 6.15(\mathrm{dd}, J=15.8,5.9 \mathrm{~Hz}, 0.77 \mathrm{H}), 4.74(\mathrm{ddd}, J=5.6,4.0,1.7 \mathrm{~Hz}, 0.22 \mathrm{H})$, $4.68(\mathrm{ddd}, J=5.7,3.9,1.5 \mathrm{~Hz}, 0.76 \mathrm{H}), 4.57$ (ddd, $J=5.9,3.9,1.5 \mathrm{~Hz}, 1 \mathrm{H}), 4.09$ (t, $J=4.2 \mathrm{~Hz}, 0.22 \mathrm{H})$, $3.11-3.01(\mathrm{~m}, 1.51 \mathrm{H}), 2.59-2.45(\mathrm{~m}, 0.23 \mathrm{H}), 2.38-2.26(\mathrm{~m}, 1.23 \mathrm{H}), 2.19(\mathrm{dt}, J=18.0,9.6 \mathrm{~Hz}, 0.80 \mathrm{H})$, $2.11-1.99(\mathrm{~m}, 1 \mathrm{H}), 1.84(\mathrm{dd}, J=20.5,11.7 \mathrm{~Hz}, 1 \mathrm{H}), 1.61-1.47(\mathrm{~m}, 1 \mathrm{H}) .{ }^{13} \mathbf{C} \mathbf{N M R}\left(100 \mathrm{MHz}, \mathrm{CDCl}_{3}\right) \delta$ $159.24,159.17,136.74,136.72$, 132.24, 128.49, 128.46, 127.67, 127.62, 126.66, 126.63, 125.78, 82.51, 
81.90, 75.43, 75.30, 45.91, 38.21, 36.92, 36.62, 31.90, 30.31, 25.32, 18.82. IR (KBr, cm $\left.{ }^{-1}\right) 3270,2945$, 1659, 1494, 1445, 1076. HRMS calcd $\mathrm{C}_{15} \mathrm{H}_{18} \mathrm{NO}_{2}[\mathrm{M}+\mathrm{H}]^{+}:$244.1332. Found: 244.1325.

$\mathrm{TsCl}$ (78 $\mathrm{mg}, 0.41 \mathrm{mmol}$ ) was added in one portion to a solution of $\mathbf{3 g}(46.0 \mathrm{mg}, 0.19 \mathrm{mmol})$ in pyridine $(3 \mathrm{~mL})$. The reaction mixture was heated to reflux for 24 hours. The reaction was quenched with saturated $\mathrm{NaHCO}_{3}$ solution $(15 \mathrm{~mL})$. The aqueous phase was extracted with EtOAc $(15 \mathrm{~mL} \times 2)$ and the combined organic extracts were dried over $\mathrm{MgSO}_{4}$, filtered and concentrated under vacue. The residue was dissolved in $\mathrm{MeOH}(12 \mathrm{~mL})$, and $1 \mathrm{M} \mathrm{HCl}(6.0 \mathrm{~mL})$ was added in one portion. The reaction mixture was heated to reflux for 2 hours, before it was quenched with saturated $\mathrm{NaHCO}_{3}$ solution $(20 \mathrm{~mL})$. The aqueous phase was extracted with EtOAc $(20 \mathrm{~mL} \times 2)$ and the combined organic extracts were washed with brine $(10 \mathrm{~mL})$, dried over $\mathrm{MgSO}_{4}$, filtered, and concentrated under vacue. The residue was purified by silica gel chromatography (EtOAc) to give $\mathbf{3 h}$ as a colorless oil in $53 \%$ yield $(22.5 \mathrm{mg}) . \mathrm{R}_{f}=0.2$ (EtOAc). ${ }^{1} \mathbf{H}$ NMR $\left(400 \mathrm{MHz}, \mathrm{CDCl}_{3}\right) \delta 7.45-7.37$ (m, 2H), 7.35 - 7.27 (m, 3H), 6.75 (dd, J = 15.8, 1.2 $\mathrm{Hz}, 1 \mathrm{H}), 6.30(\mathrm{dd}, J=15.9,6.8 \mathrm{~Hz}, 1 \mathrm{H}), 6.12(\mathrm{~d}, J=7.2 \mathrm{~Hz}, 1 \mathrm{H}), 4.75$ - 4.69 (m, 1H), 4.67 (ddd, $J=6.9$, 4.4, $1.3 \mathrm{~Hz}, 1 \mathrm{H}), 3.72$ - $3.62(\mathrm{~m}, 1 \mathrm{H}), 2.96$ (ddd, $J=15.6,11.8,5.3 \mathrm{~Hz}, 1 \mathrm{H}), 2.59$ - 2.43 (m, 2H), 2.10 $1.96(\mathrm{~m}, 2 \mathrm{H}), 1.73-1.63(\mathrm{~m}, 1 \mathrm{H}) .{ }^{13} \mathbf{C}$ NMR $\left(101 \mathrm{MHz}, \mathrm{CDCl}_{3}\right) \delta 177.59,134.40,128.61,128.11,126.72$, 123.99, 84.08, 56.03, 40.20, 32.19, 29.53. IR $\left(\mathrm{KBr}, \mathrm{cm}^{-1}\right)$ 3282, 2927, 1639, 1449,1203, 1171. HRMS calcd $\mathrm{C}_{15} \mathrm{H}_{18} \mathrm{NO}_{2}[\mathrm{M}+\mathrm{H}]^{+}:$244.1332. Found: 244.1339. 


\section{Deuterium labeling experiments}

(1). Deuterium labeling experiment of $d \mathbf{- 1} \mathbf{a}$ ' for the exo product
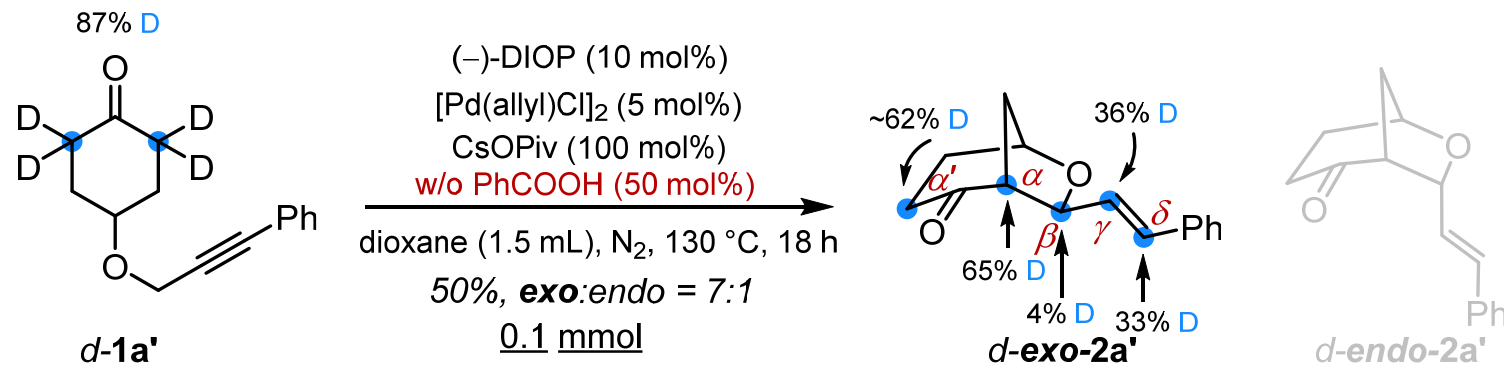

Experimental procedure C: The reaction was conducted on a $0.1 \mathrm{mmol}$ scale. A $4 \mathrm{~mL}$ vial was flamedried and charged with $[\mathrm{Pd}(\mathrm{allyl}) \mathrm{Cl}]_{2}(1.8 \mathrm{mg}, 0.005 \mathrm{mmol})$ and (-)-DIOP (4.9 mg, $\left.0.01 \mathrm{mmol}\right)$. The vial was sealed and transferred into a glove box. Inside the glovebox, 1,4-dioxane (distilled over $\mathrm{Na}, 1.5 \mathrm{~mL}$ ) was added and stirred for $10 \mathrm{~min}$. Then, the ketone $d-\mathbf{1 a}$ ' $(0.1 \mathrm{mmol}, 23.2 \mathrm{mg})$, CsOPiv (23.4 mg, 0.1 mmol) were added sequentially. After purged under $\mathrm{N}_{2}$ atmosphere for $5 \mathrm{~min}$, the tube was sealed with a black cap, transferred out of the glovebox and heated in a pie-block at $130{ }^{\circ} \mathrm{C}$. After about $18 \mathrm{~h}$ (TLC monitoring the reaction in the glovebox), the mixture was allowed to cool to room temperature.

For ${ }^{1} \mathrm{H}$-NMR analysis of the endo:exo ratio and yield: After cooled to room temperature, the reaction mixture was filtered through a short plug of celite and eluted with DCM to remove the solid precipitate. The filtrate was then concentrated under vacuo. $\mathrm{CDCl}_{3}(1 \mathrm{~mL})$ and 1,1,2,2-tetrachloroethane (as the internal standard, about $25 \mathrm{mg}$ ) were added to the residue and the resulting mixture was directly used for ${ }^{1} \mathrm{H}-\mathrm{NMR}$ analysis.

For pure compound isolation: After ${ }^{1} \mathrm{H}-\mathrm{NMR}$ analysis of the endo:exo ratio, carefully transfer the compound from the NMR tube to a $20 \mathrm{~mL}$ vial and wash NMR tube 3 times with DCM. The mixture was concentrated under vacuo and purified by column chromatography (hexane:EtOAc $=4: 1$ ) to yield the desired $d$-exo-2a'as a pale oil $50 \%$ yield $(11.6 \mathrm{mg})$. 


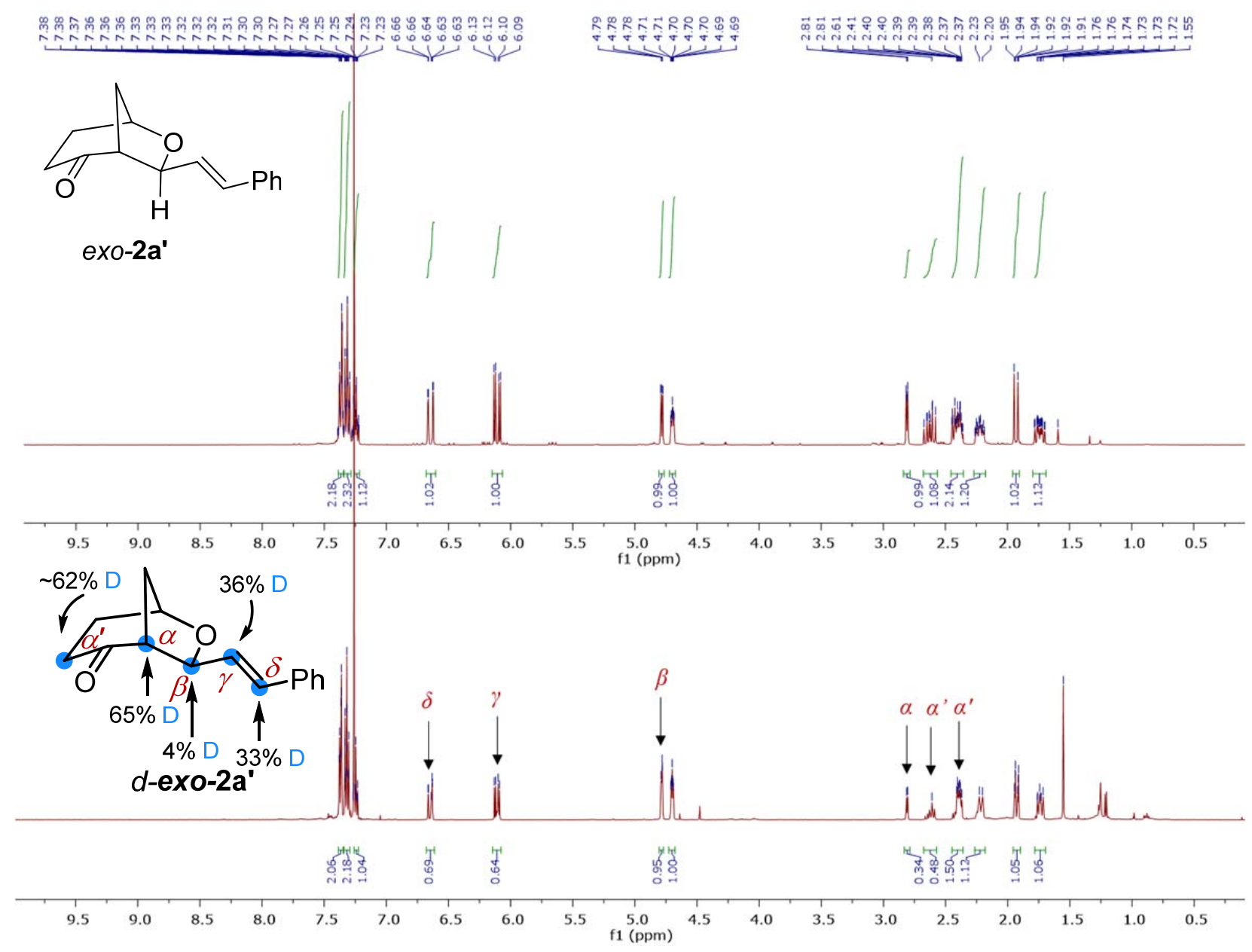

(2). Deuterium labeling experiment of $d-\mathbf{1} \mathbf{a}$ " for the exo product

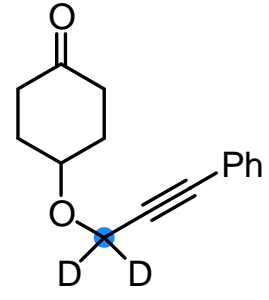

76\% D

d-1a"

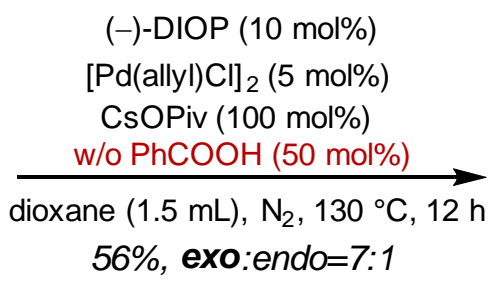

$\underline{0.1} \underline{\mathrm{mmol}}$

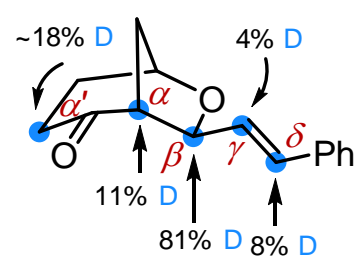

d-exo-2a"

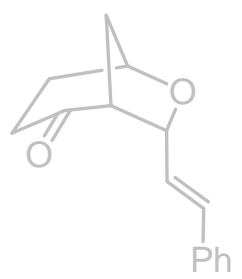

d-endo-2a"

\section{Experimental procedure D:}

The reaction was conducted on a $0.1 \mathrm{mmol}$ scale. A $4 \mathrm{~mL}$ vial was flame-dried and charged with $[\mathrm{Pd}(\text { allyl }) \mathrm{Cl}]_{2}(1.8 \mathrm{mg}, 0.005 \mathrm{mmol})$ and (-)-DIOP $(4.9 \mathrm{mg}, 0.01 \mathrm{mmol})$. The vial was sealed with a black cap and transferred into a glove box. Inside the glovebox, 1,4-dioxane (distilled over $\mathrm{Na}, 1.5 \mathrm{~mL}$ ) was added and stirred for $10 \mathrm{~min}$. Then the ketone $d-\mathbf{1 a}$ "' $(0.1 \mathrm{mmol}, 23.0 \mathrm{mg})$, CsOPiv $(23.4 \mathrm{mg}, 0.1 \mathrm{mmol})$ 
were added sequentially. After purged under $\mathrm{N}_{2}$ atmosphere for $5 \mathrm{~min}$, the tube was sealed with a black cap, transferred out of the glovebox and heated in a pie-block at $130^{\circ} \mathrm{C}$. After about $12 \mathrm{~h}$ (TLC monitor the reaction in the glovebox), the mixture was allowed to cool to room temperature.

For ${ }^{1} \mathrm{H}$-NMR analysis the endo:exo ratio and yield: After cooled to room temperature, the reaction mixture was filtered through a short plug of celite and eluted with DCM to remove the solid precipitate. The filtrate was then concentrated under vacuo. $\mathrm{CDCl}_{3}(1 \mathrm{~mL})$ and 1,1,2,2-tetrachloroethane (as the internal standard, about $25 \mathrm{mg}$ ) were added to the residue and the resulting mixture was directly used for ${ }^{1} \mathrm{H}-\mathrm{NMR}$ analysis.

For pure compound isolation: After ${ }^{1} \mathrm{H}-\mathrm{NMR}$ analysis the endo:exo ratio, carefully transfer the compound from the NMR tube to a $20 \mathrm{~mL}$ vial and wash NMR tube 3 times with DCM. The mixture was concentrated under vacuo and purified by column chromatography (hexane:EtOAc $=4: 1$ ) to yield the desired $d$-exo-2a"' as a pale oil $56 \%$ yield $(12.9 \mathrm{mg})$.

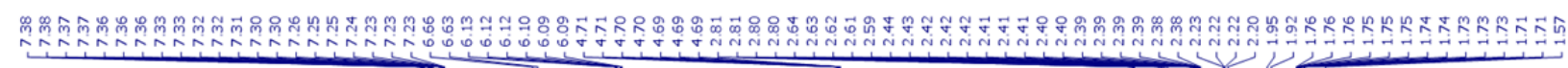

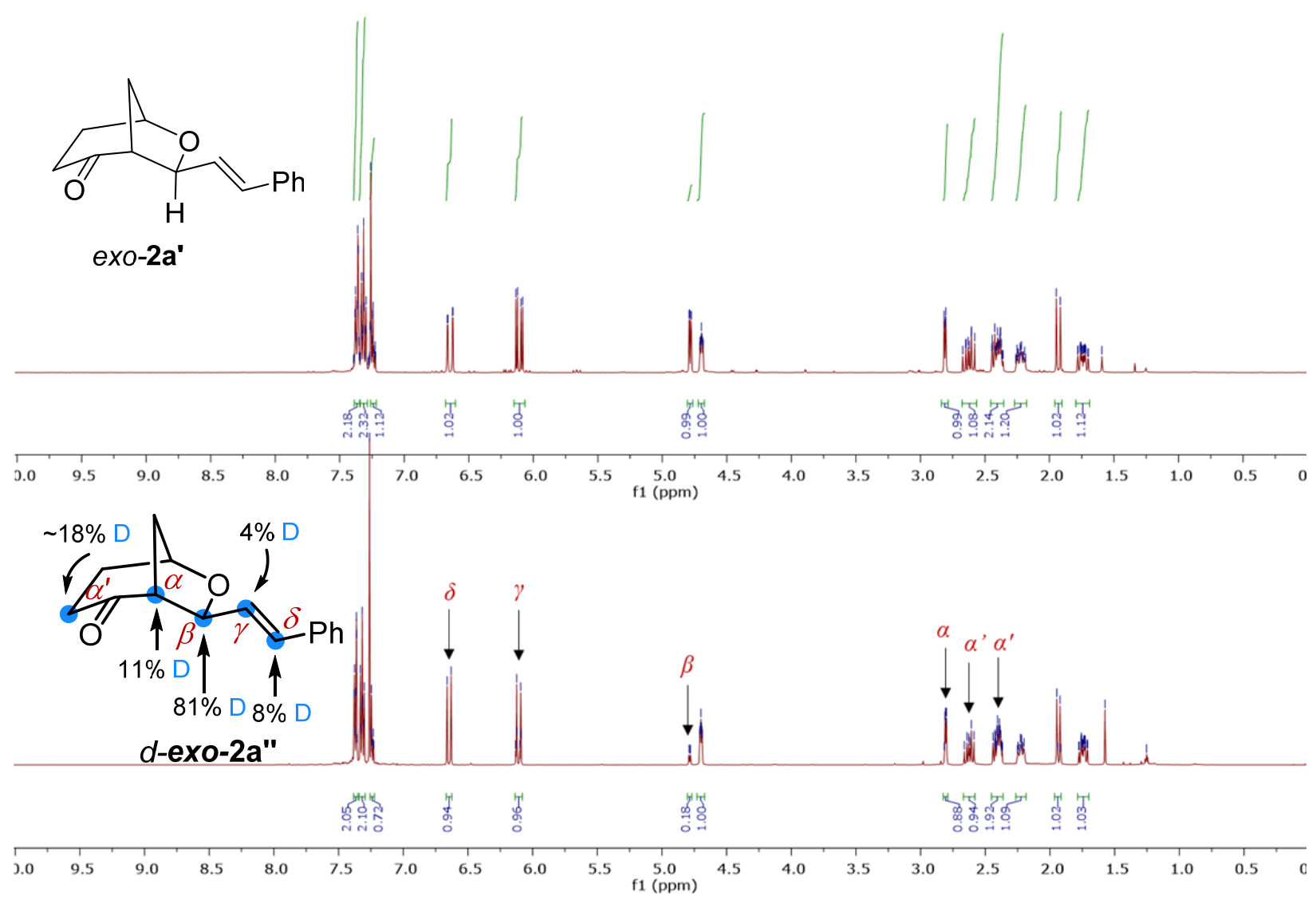


(3) Deuterium labeling experiment of $d$-1a' for the endo product

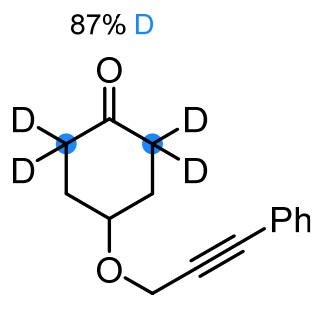

$d-1 a^{\prime}$

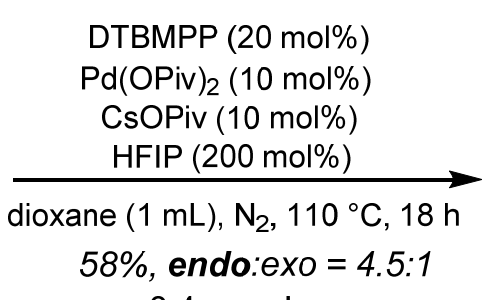

$\underline{0.1} \underline{\mathrm{mmol}}$

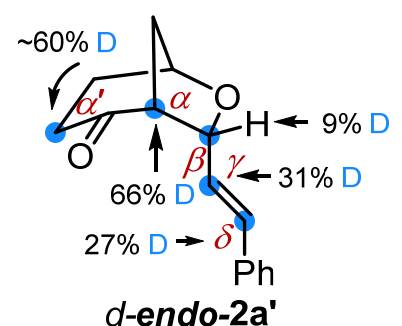

d-endo-2a'

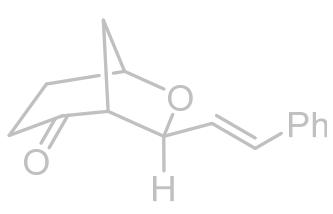

d-exo-2a'

Experimental procedure E: The reaction was conducted on a $0.1 \mathrm{mmol}$ scale. A $4 \mathrm{~mL}$ vial was flamedried and charged with $\mathrm{Pd}(\mathrm{OPiv})_{2}(3.06 \mathrm{mg}, 0.01 \mathrm{mmol})$ and DTBMPP $(14 \mathrm{mg}, 0.02 \mathrm{mmol})$. The vial was sealed and transferred into a glove box. Inside the glovebox, 1,4-dioxane (distilled over $\mathrm{Na}, 1 \mathrm{~mL}$ ) was added and stirred for $10 \mathrm{~min}$. Then, the ketone $d$-1a' $(0.1 \mathrm{mmol}, 23.2 \mathrm{mg})$, CsOPiv $(2.34 \mathrm{mg}, 0.01$ mmol) and HFIP ( $21 \mathrm{uL}, 0.2 \mathrm{mmol}$ ) were added sequentially. After purged under $\mathrm{N}_{2}$ atmosphere for 5 min, the tube was sealed with a black cap, transferred out of the glovebox and heated in a pie-block at $110{ }^{\circ} \mathrm{C}$. After about $18 \mathrm{~h}$ (TLC monitoring the reaction in the glovebox), the mixture was allowed to cool to room temperature.

For ${ }^{1} \mathrm{H}$-NMR analysis of the endo:exo ratio and yield: After cooled to room temperature, the reaction mixture was filtered through a short plug of celite and eluted with DCM to remove the solid precipitate. The filtrate was then concentrated under vacuo. $\mathrm{CDCl}_{3}(1 \mathrm{~mL})$ and 1,1,2,2-tetrachloroethane (as the internal standard, about $25 \mathrm{mg}$ ) were added to the residue and the resulting mixture was directly used for ${ }^{1} \mathrm{H}-\mathrm{NMR}$ analysis.

For pure compound isolation: After ${ }^{1} \mathrm{H}-\mathrm{NMR}$ analysis of the endo:exo ratio, carefully transfer the compound from the NMR tube to a $20 \mathrm{~mL}$ vial and wash NMR tube 3 times with DCM. The mixture was concentrated under vacuo and purified by column chromatography (hexane:DCM:EtOAc $=3: 2: 1$ ) to yield the desired $d$-endo-2a' as white solid $58 \%$ yield $(13.5 \mathrm{mg})$. 


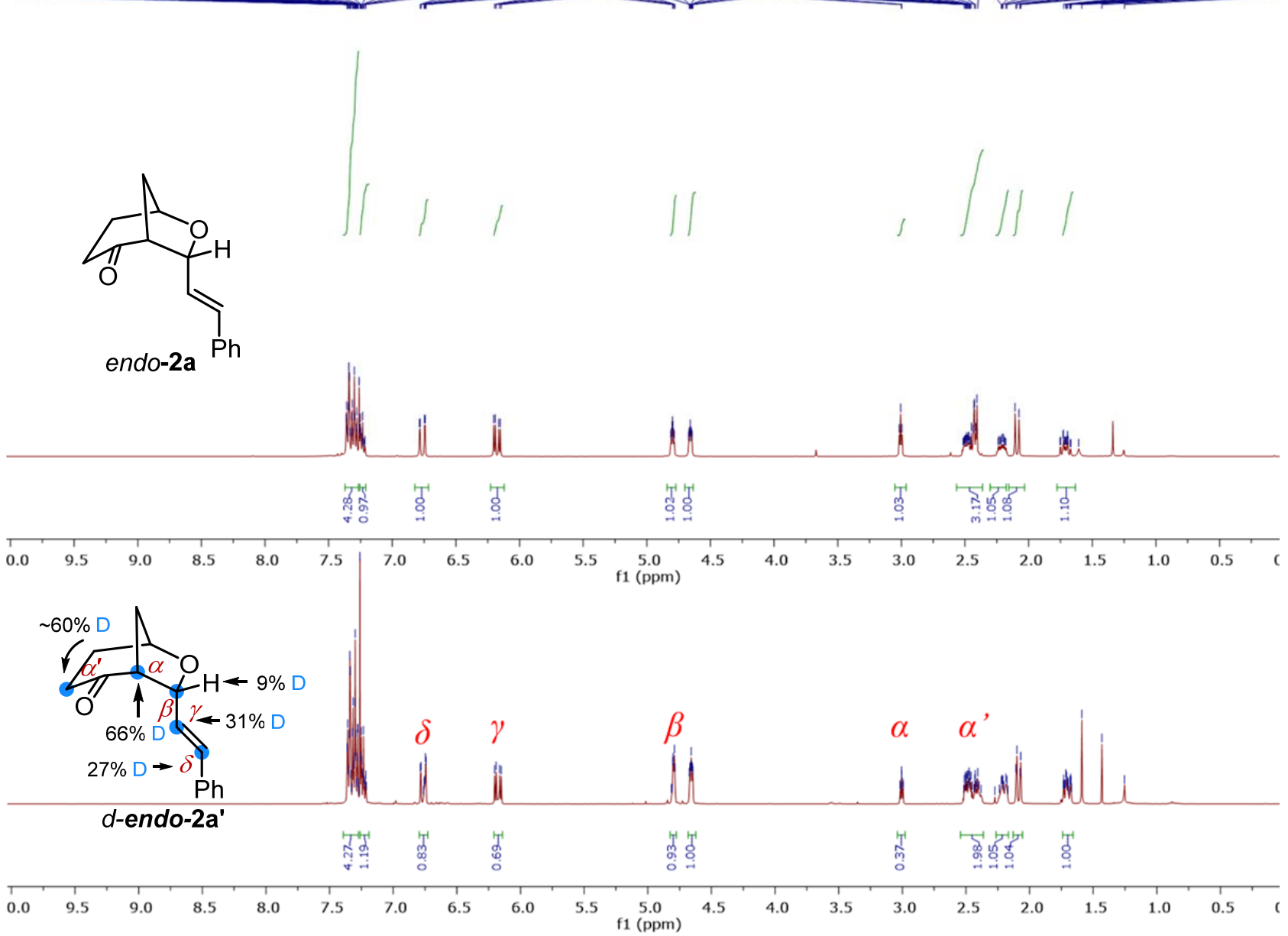

(4). Deuterium labeling experiment of $d \mathbf{- 1} \mathbf{a}$ ', for the endo product<smiles>[2H]C([2H])(C#CPc1ccccc1)OC1CCC(=O)CC1</smiles>

$76 \%$ D

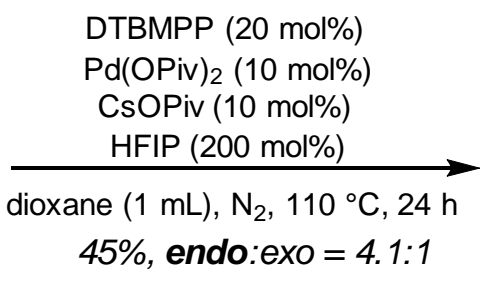

$\underline{0.1} \underline{\mathrm{mmol}}$

d-1a"
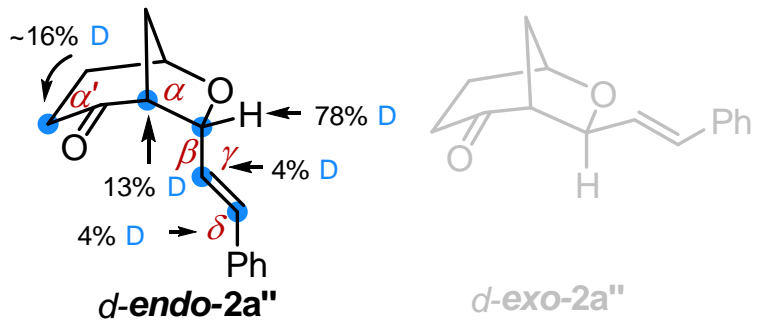

d-exo-2a"

\section{Experimental procedure F:}

The reaction was conducted on a $0.1 \mathrm{mmol}$ scale. A $4 \mathrm{~mL}$ vial was flame-dried and charged with $\mathrm{Pd}(\mathrm{OPiv})_{2}(3.06 \mathrm{mg}, 0.005 \mathrm{mmol})$ and DTBMPP $(14 \mathrm{mg}, 0.02 \mathrm{mmol})$. The vial was sealed with a black 
cap and transferred into a glove box. Inside the glovebox, 1,4-dioxane (distilled over $\mathrm{Na}, 1 \mathrm{~mL}$ ) was added and stirred for $10 \mathrm{~min}$. Then the ketone $d-1 \mathbf{a}$ ' $(0.1 \mathrm{mmol}, 23.0 \mathrm{mg})$, CsOPiv $(2.34 \mathrm{mg}, 0.01 \mathrm{mmol})$ and HFIP ( $21 \mathrm{uL}, 0.2 \mathrm{mmol})$ were added sequentially. After purged under $\mathrm{N}_{2}$ atmosphere for $5 \mathrm{~min}$, the tube was sealed with a black cap, transferred out of the glovebox and heated in a pie-block at $110{ }^{\circ} \mathrm{C}$. After about $24 \mathrm{~h}$ (TLC monitor the reaction in the glovebox), the mixture was allowed to cool to room temperature.

For ${ }^{1} \mathrm{H}$-NMR analysis the endo:exo ratio and yield: After cooled to room temperature, the reaction mixture was filtered through a short plug of celite and eluted with DCM to remove the solid precipitate. The filtrate was then concentrated under vacuo. $\mathrm{CDCl}_{3}(1 \mathrm{~mL})$ and 1,1,2,2-tetrachloroethane (as the internal standard, about $25 \mathrm{mg}$ ) were added to the residue and the resulting mixture was directly used for ${ }^{1} \mathrm{H}-\mathrm{NMR}$ analysis.

For pure compound isolation: After ${ }^{1} \mathrm{H}-\mathrm{NMR}$ analysis the endo:exo ratio, carefully transfer the compound from the NMR tube to a $20 \mathrm{~mL}$ vial and wash NMR tube 3 times with DCM. The mixture was concentrated under vacuo and purified by column chromatography (hexane:DCM:EtOAc $=3: 2: 1$ ) to yield the desired $d$-exo-2a"'as white solid $45 \%$ yield (10.4 mg).

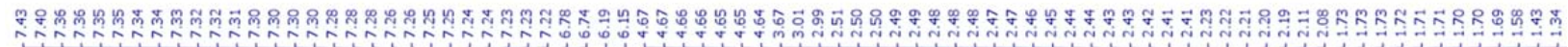

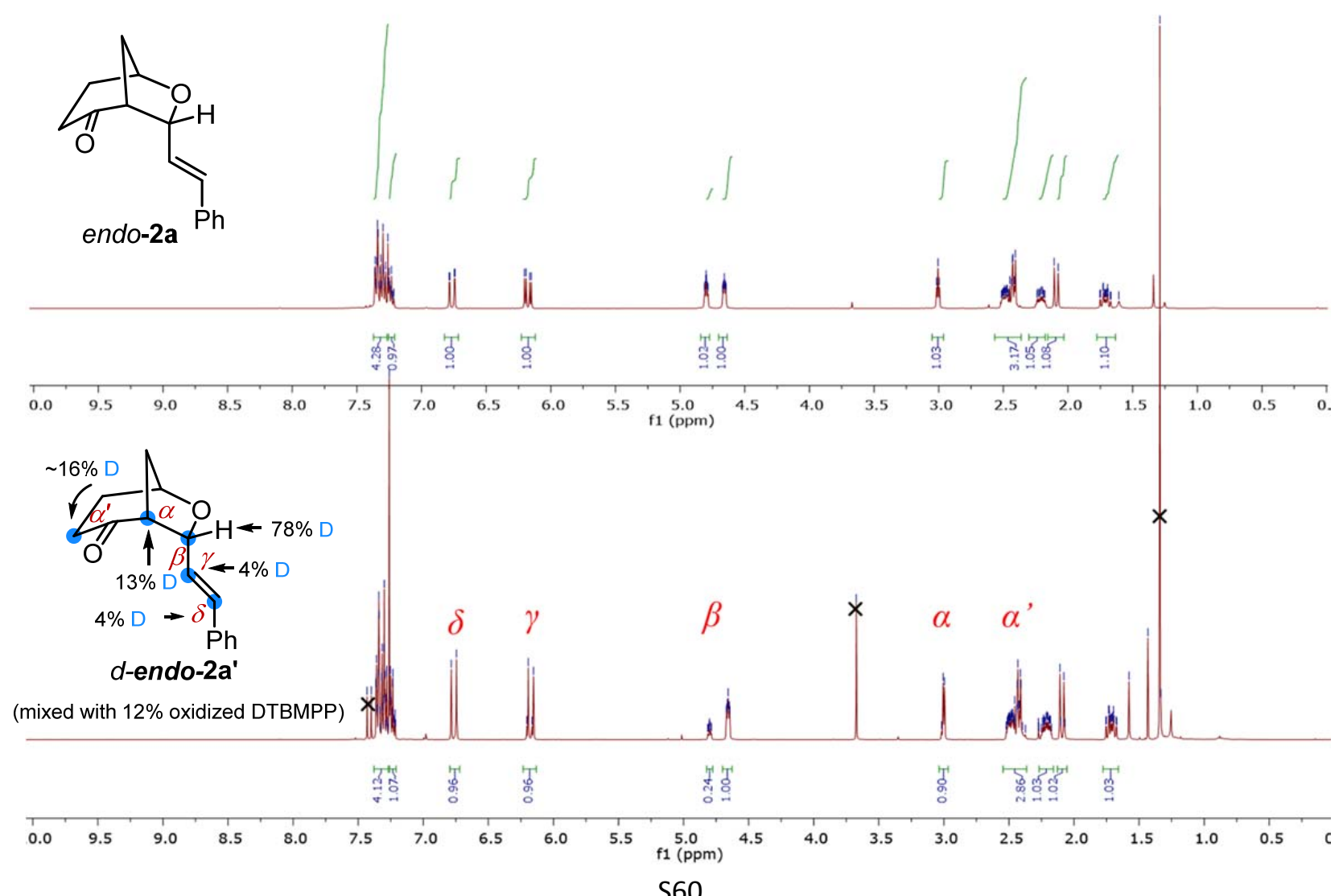


VIII. Crystal data and structural confirmation via 2-D NMR Spectroscopy

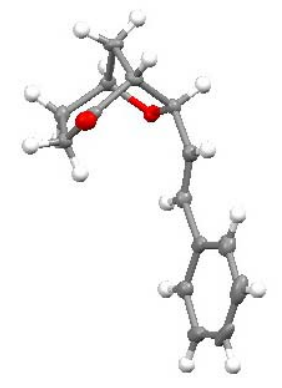

Table S1. Crystal data and structure refinement for pf-a-p2 (endo-2a).

Identification code

pf-a-p2 (endo-2a)

Empirical formula

$\mathrm{C}_{15} \mathrm{H}_{16} \mathrm{O}_{2}$

Formula weight

228.28

Temperature/K

100

Crystal system

orthorhombic

Space group

$\mathrm{P} 2{ }_{1} 2{ }_{1}{ }_{1}$

$\mathrm{a} / \AA$

$5.6039(7)$

$\mathrm{b} / \AA$

10.7509(13)

$\mathrm{c} / \AA$

19.196(2)

$\alpha /{ }^{\circ}$

90

$\beta /{ }^{\circ}$

90

$\gamma /{ }^{\circ}$

90

Volume $/ \AA^{3}$

$1156.5(2)$

Z

4

$\rho_{\text {calc }} \mathrm{g} / \mathrm{cm}^{3}$

1.311

$\mu / \mathrm{mm}^{-1}$

0.086

$\mathrm{F}(000)$

488.0

Crystal size $/ \mathrm{mm}^{3}$

$0.2 \times 0.1 \times 0.1$

Radiation

$\operatorname{MoK} \alpha(\lambda=0.71073)$

$2 \Theta$ range for data collection ${ }^{\circ}$

Index ranges

4.342 to 61.854

$-7 \leq \mathrm{h} \leq 8,-14 \leq \mathrm{k} \leq 15,-27 \leq 1 \leq 27$

Reflections collected

11245

Independent reflections

$3408\left[\mathrm{R}_{\text {int }}=0.0307, \mathrm{R}_{\text {sigma }}=0.0314\right]$

Data/restraints/parameters

$3408 / 36 / 154$

Goodness-of-fit on $\mathrm{F}^{2}$

1.046

Final $R$ indexes $[\mathrm{I}>=2 \sigma(\mathrm{I})]$

$\mathrm{R}_{1}=0.0489, \mathrm{wR}_{2}=0.1260$ 
Final $\mathrm{R}$ indexes [all data] $\quad \mathrm{R}_{1}=0.0557, \mathrm{wR}_{2}=0.1314$

Largest diff. peak/hole / e $\AA^{-3} \quad 0.68 /-0.23$

Flack parameter

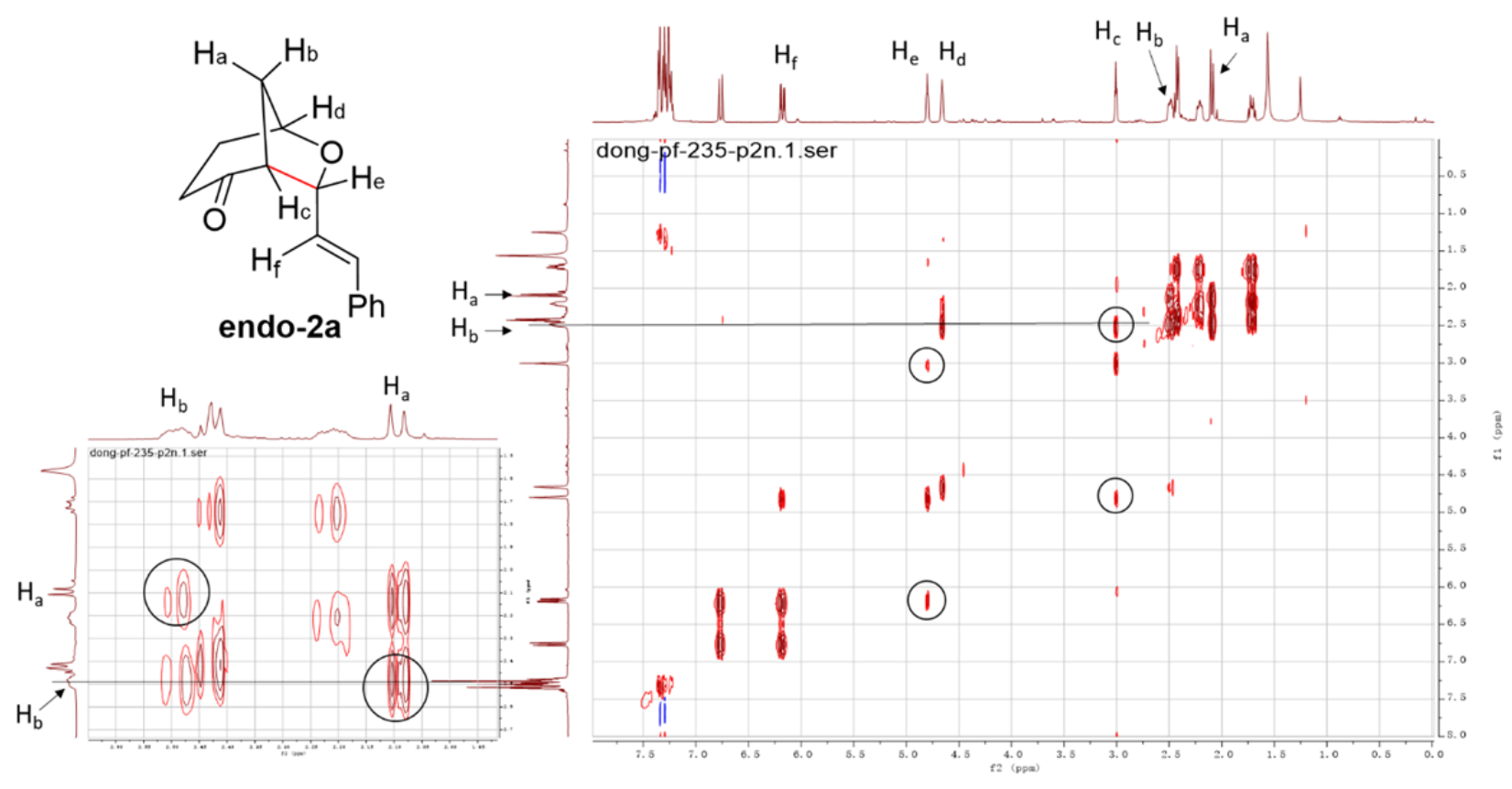

COSY of endo-2a

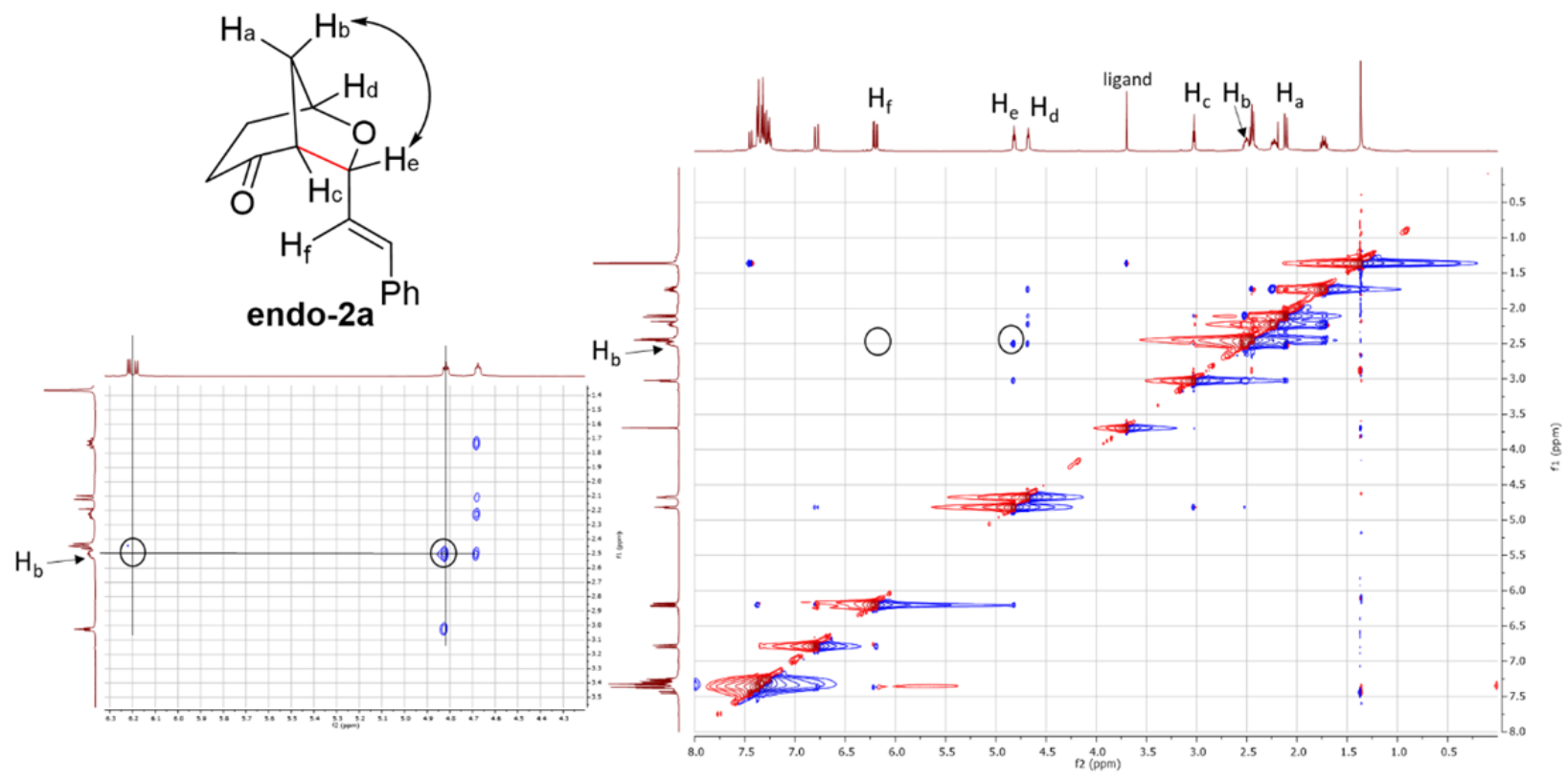

NOESY of endo-2a 

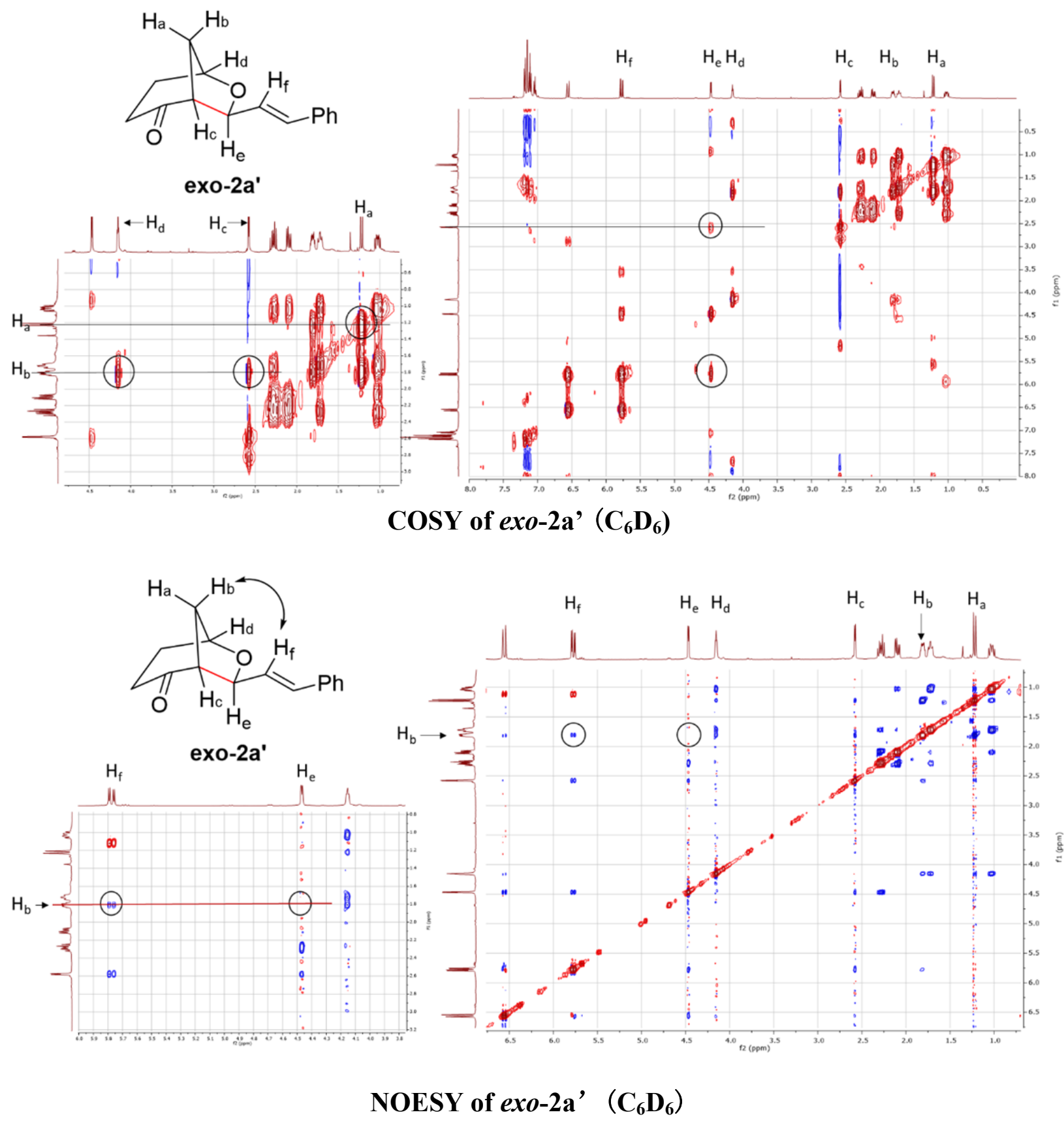

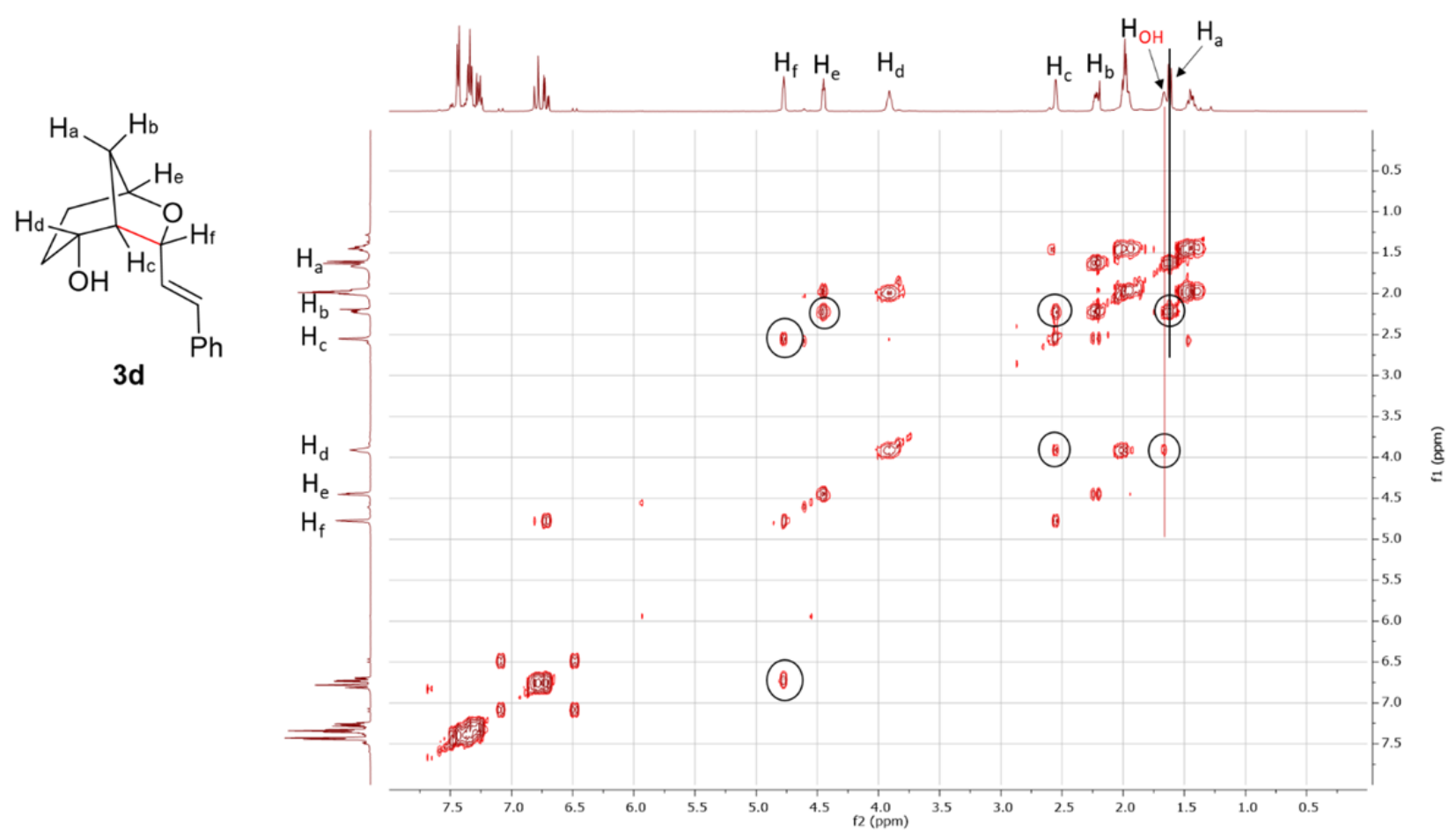

COSY of 3d

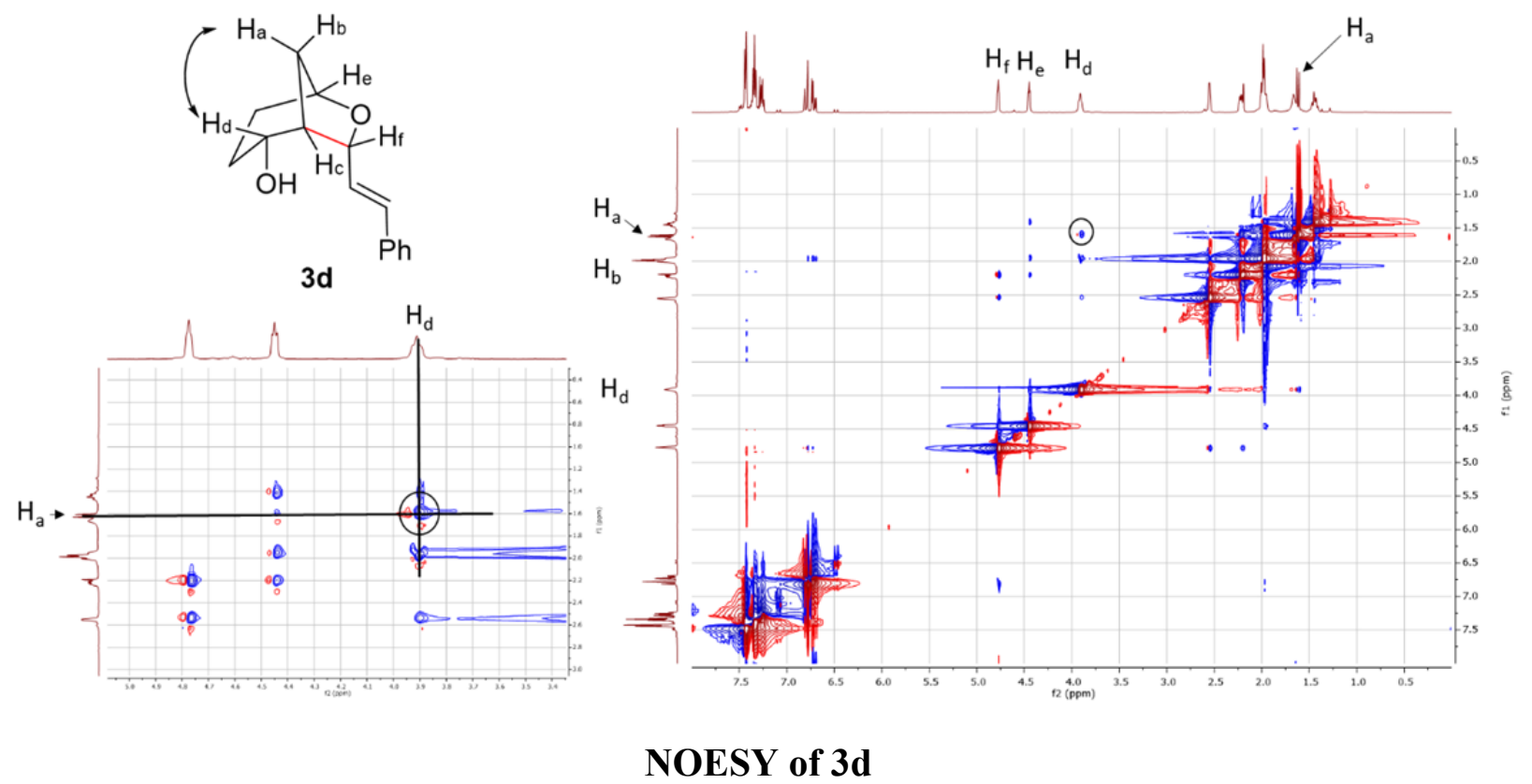


<smiles>C/C(=C\C(=O)C1CC1C(=O)CC1CC1)c1ccccc1</smiles>

exo-2v'

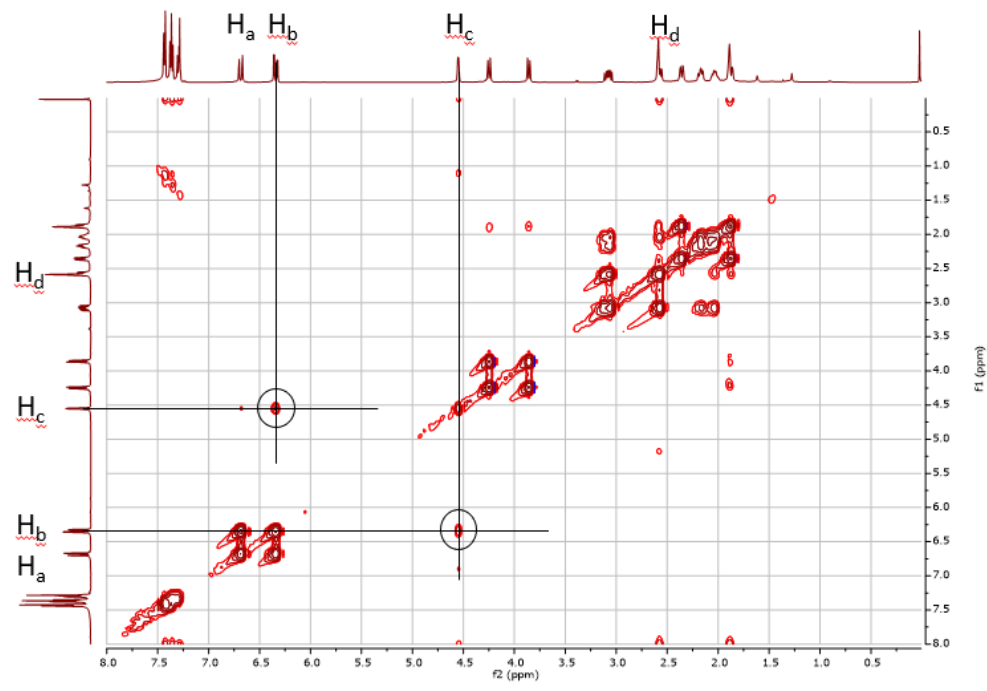

COSY of exo-2v'

The structure of $\mathbf{2} \mathbf{v}^{\prime}$ (major diastereomer) is determined as exo based on the analysis of the coupling constant of $\mathrm{H}_{\mathrm{c}}$, which is assigned as axial.

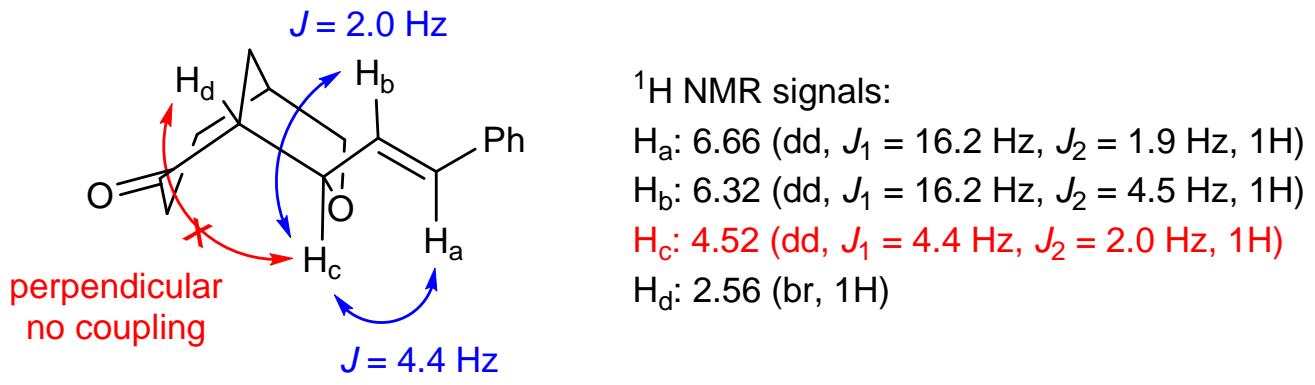

exo-2v'

The structure of $\mathbf{2} \mathbf{v}^{\prime}$ ' (minor diastereomer) is determined as endo based on the analysis of the coupling constant of $\mathrm{H}_{\mathfrak{c}}$, which is assigned as equatorial.

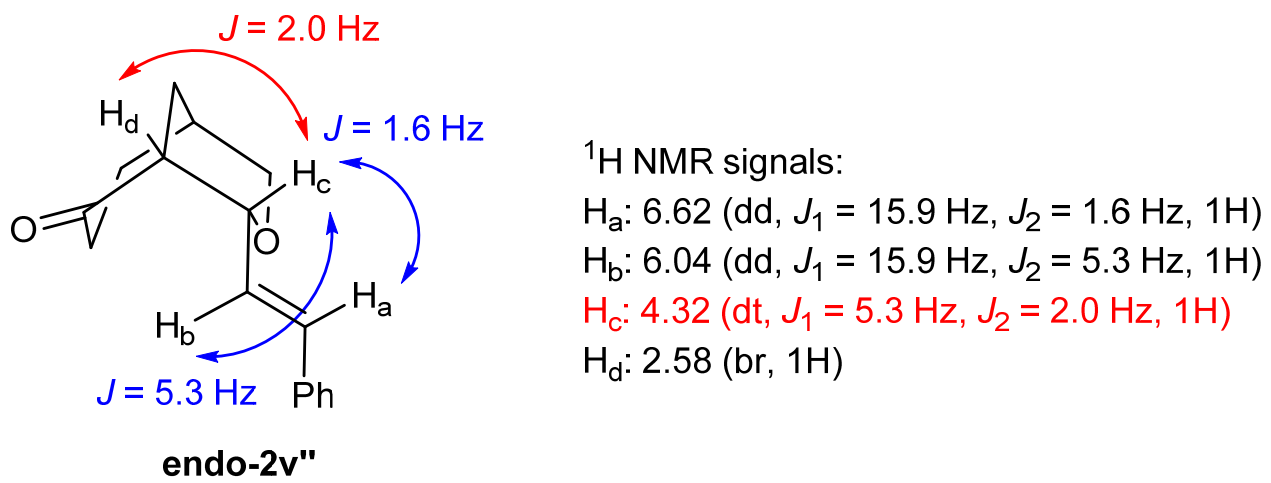


The following compound, reported in the literature ${ }^{11}$, is supportive for the determination of the structure of endo-2v'. The crystal structure unambiguously shows the endo structure of the compound. The coupling constant between $\mathrm{H}_{\mathrm{a}}$ and $\mathrm{H}_{\mathrm{b}}$ is $2.0 \mathrm{~Hz}$, consistent with the "H NMR data obtained for endo-2v'".

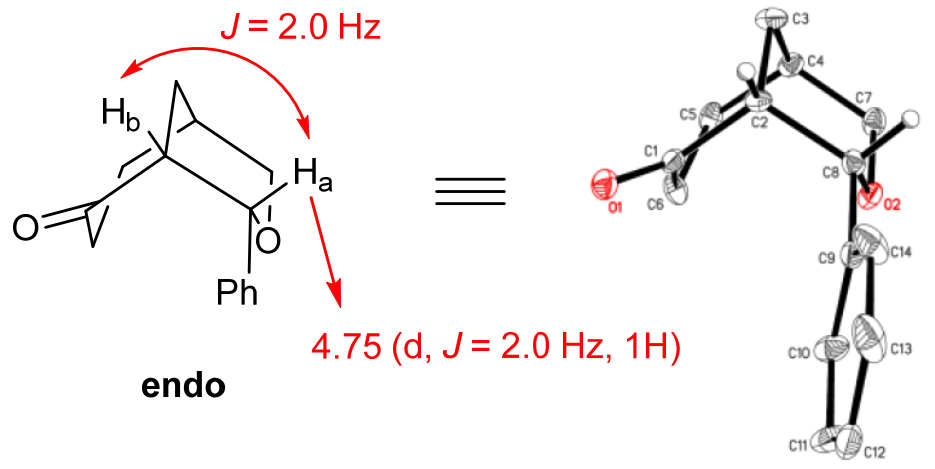




\section{Proposed stereochemical models for the stereodivergency}

The exo-selective reaction requires a bidentate phosphine ligand. It is proposed that, upon forming the Pd- $\pi$-allyl species, the enolate unlikely coordinates to the Pd; instead, it would behave as an external nucleophile to attack the $\mathrm{Pd}-\pi$-allyl species to give the exo product. A stereochemical model is proposed here.
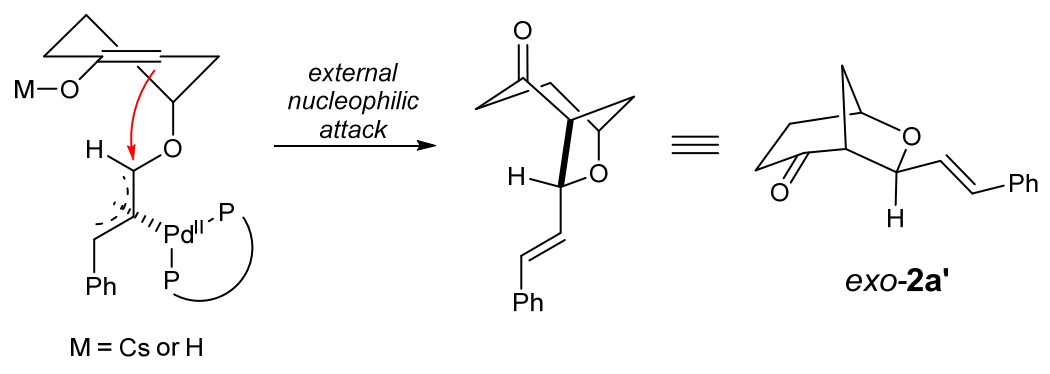

The endo-selective reaction employs a monodentate phosphine ligand. Given that monodentate phosphine ligands could generate a less coordinated Pd complex, a Pd enolate would likely be produced after forming the $\mathrm{Pd}-\pi$-allyl species. Through subsequent $\mathrm{C}-\mathrm{C}$ reductive elimination, the endo product is afforded. A stereochemical model is proposed here.

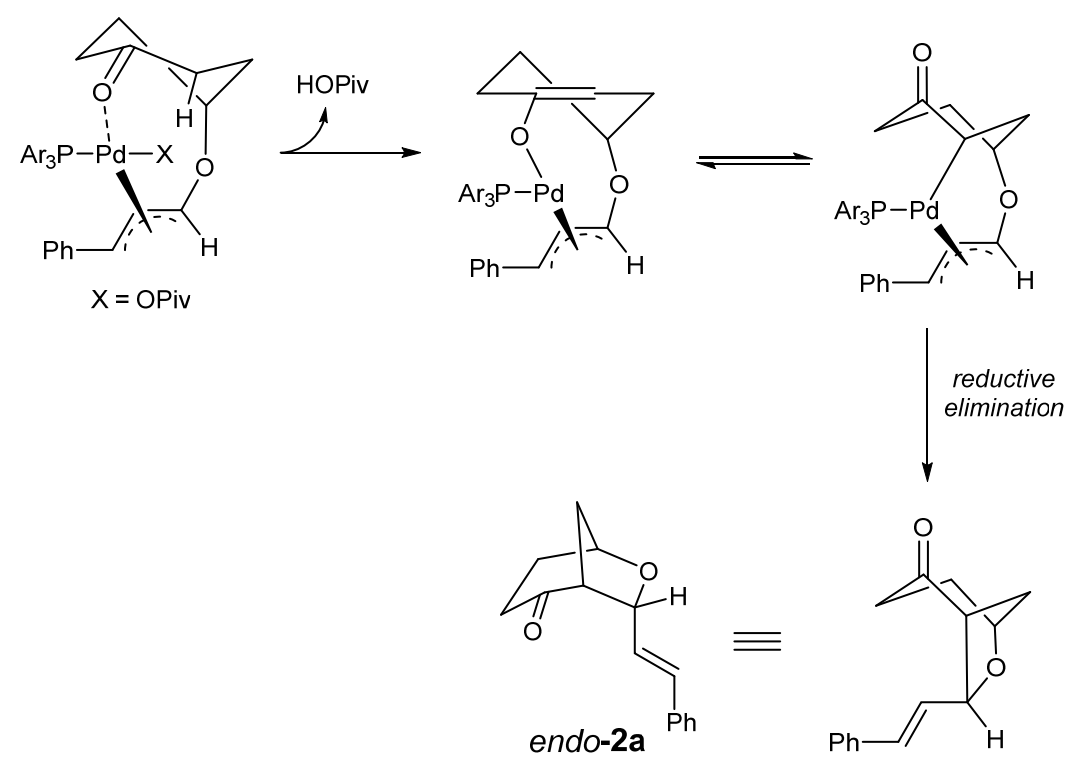




\section{References}

1) Liang, X.; Zhang, J.; Kong, H.; Wang, D. 5-Oxyl-2-Oxocyclohexylsulfonamide Compound as well as Preparation Method and Application Thereof. Patent: CN104151209, 2016, B.

2) Kitbunnadaj, R.; Hoffmann, M.; Fratantoni, S. A.; Bongers, G.; Bakker, R. A.; Wieland, K.; El, J. A.; Timmerman, H.; Leurs, R. New High Affinity $\mathrm{H}_{3}$ Receptor Agonists without a Basic Side Chain. Bioorg. Med. Chem. 2005, 13, 6309-6323.

3) Manzano, R.; Datta, S.; Paton, R. S.; Dixon, D. J. Enantioselective Silver and Amine Co - Catalyzed Desymmetrizing Cycloisomerization of Alkyne-Linked Cyclohexanones. Angew. Chem., Int. Ed, 2017, 56, 5834-5838.

4) Sharon, C.; Christoph, K.; Nanna, A.; Carsten J.; Craig M. W. Determining a Synthetic Approach to Pierisformaside C. Org. Lett. 2011, 13, 5286-5289.

5) Xu, Y.; Qi, X.; Zheng, P.; Berti, C. C.; Liu, P.; Dong, G. Deacylative Transformations of Ketones via Aromatization-Promoted C-C Bond Activation. Nature 2019, 567, 373-378.

6) Zhou, X.; Dong, G. Nickel - Catalyzed Chemo - and Enantioselective Coupling between Cyclobutanones and Allenes: Rapid Synthesis of [3.2.2] Bicycles. Angew. Chem., Int. Ed. 2016, 55, 15091-15094.

7) Yu, F.-L.; Bai, D.-C.; Liu, X.-Y.; Jiang, Y.-J.; Ding, C.-H.; Hou, X.-L. Pd-Catalyzed Allylic Alkylation of gem-Alkyl,Aryl-Disubstituted Allyl Reagents with Ketones: Diastereoselective Construction of Vicinal Tertiary and Quaternary Carbon Centers. ACS Catal. 2018, 8, 3317-3321.

8) Dongbang, S.; Pedersena, B.; Ellman, J. A. Asymmetric Synthesis of (-)-Naltrexone. Chem. Sci. 2019, 10, 535-541.

9) Schunk, S.; Linz, K.; Frormann, S.; Hinze, C.; Oberbörsch, S.; Sundermann, B.; Zemolka, S.; Englberger, W.; Germann, T.; Christoph, T.; Kögel, B.-Y.; Schröder, W.; Harlfinger, S.; Saunders, D.; Kless, A.; Schick, H.; Sonnenschein, H. Discovery of Spiro[cyclohexane-dihydropyrano[3,4b]indole]-amines as Potent NOP and Opioid Receptor Agonists. ACS Med. Chem. Lett. 2014, 5, $851-856$.

10) Kim, N.; Brooner, R. E. M.; Widenhoefer, R. A. Unexpected Skeletal Rearrangement in the Gold(I)/Silver(I)-Catalyzed Conversion of 7-Aryl-1,6-enynes to Bicyclo[3.2.0]hept-6-enes via Hidden Brønsted Acid Catalysis. Organometallics 2017, 36, 673-678.

11) McQuaid, K. M.; Sames, D. C-H Bond Functionalization via Hydride Transfer: Lewis Acid Catalyzed Alkylation Reactions by Direct Intramolecular Coupling of $\mathrm{sp}^{3} \mathrm{C}-\mathrm{H}$ Bonds and Reactive Alkenyl Oxocarbenium Intermediates. J. Am. Chem. Soc. 2009, 131, 402-403. 
XI. ${ }^{1} \mathrm{H}$ and ${ }^{13} \mathrm{C}$ NMR spectra

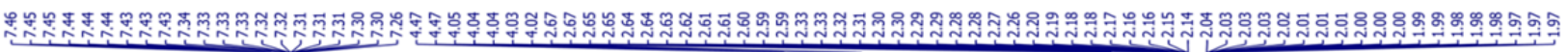
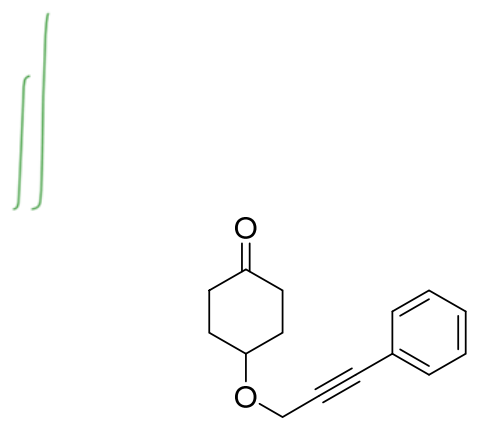

$1 a$
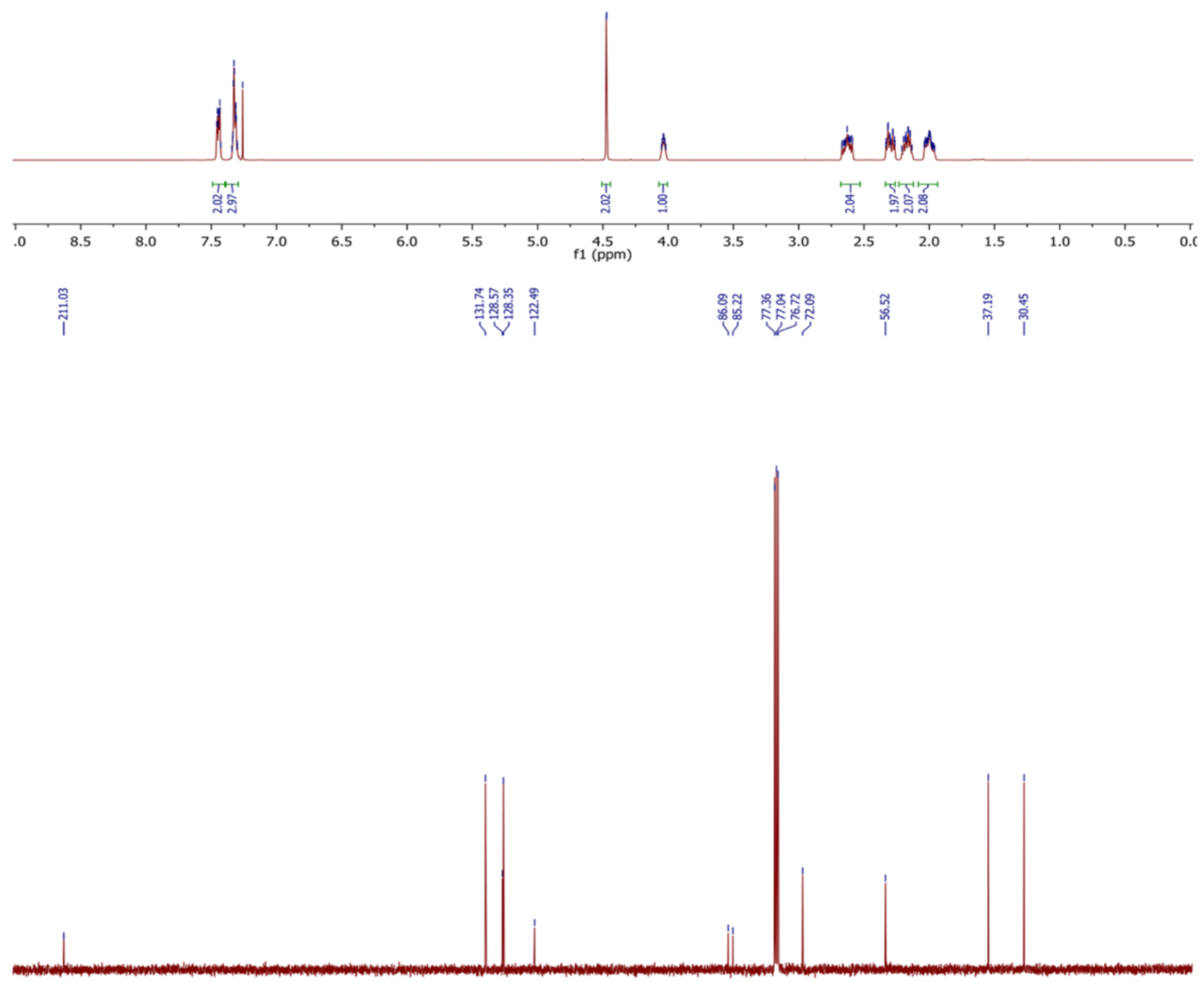

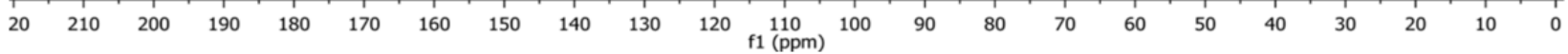
S70 


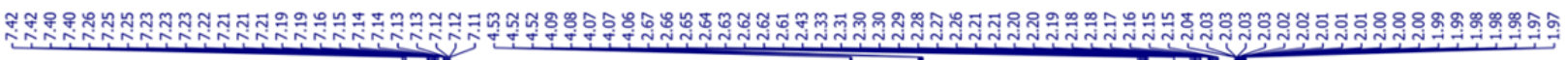
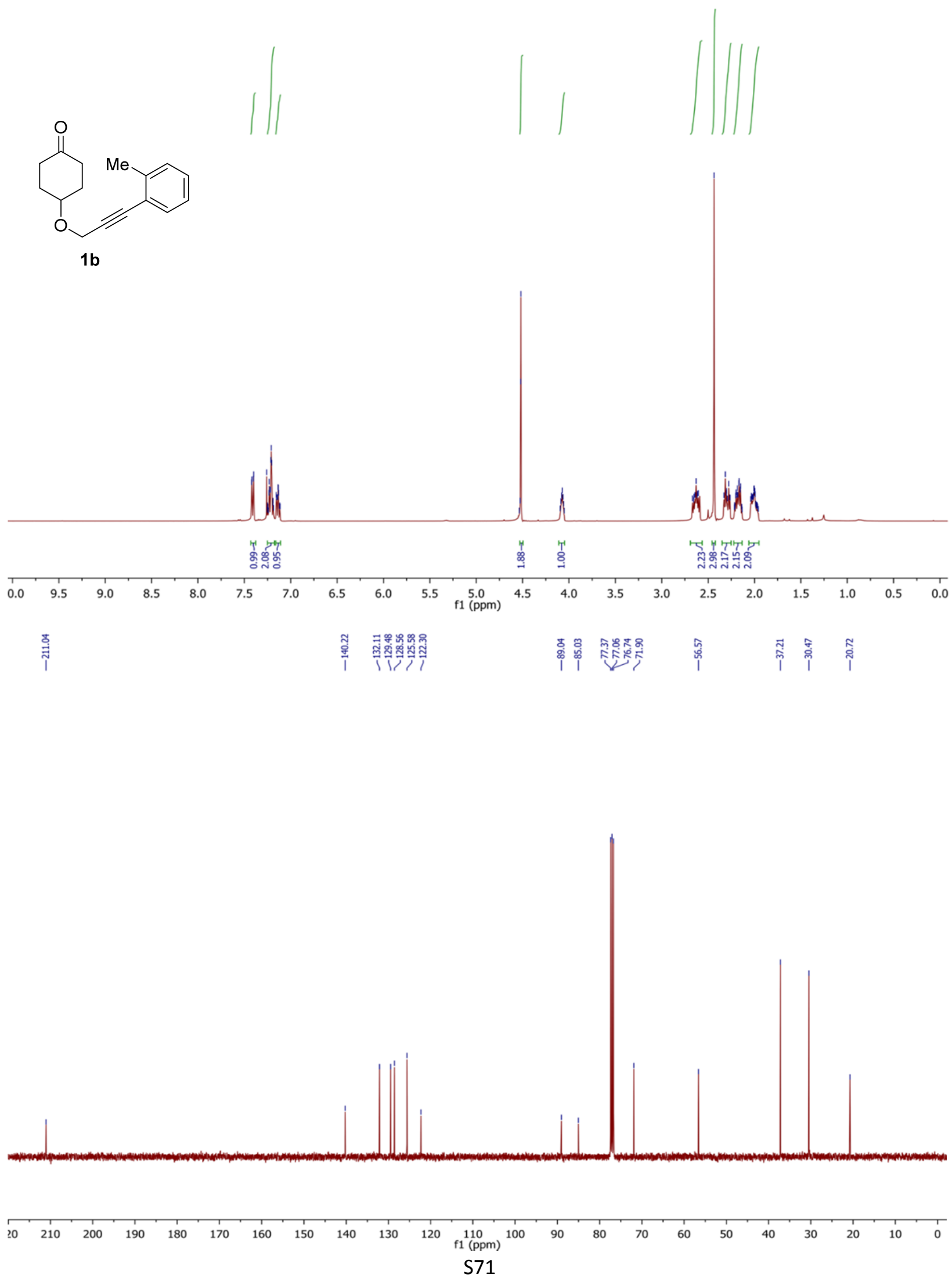


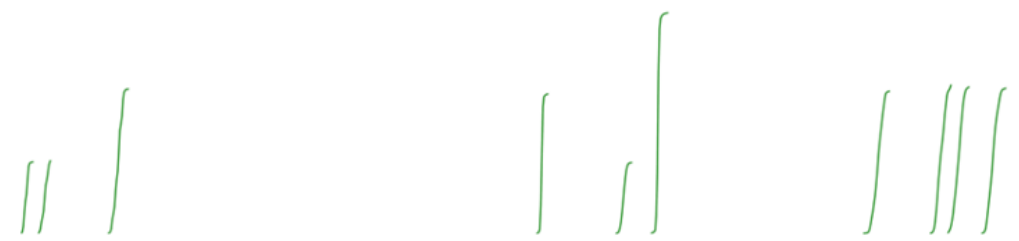<smiles>COc1ccccc1C#CCOC1CCC(=O)CC1</smiles>

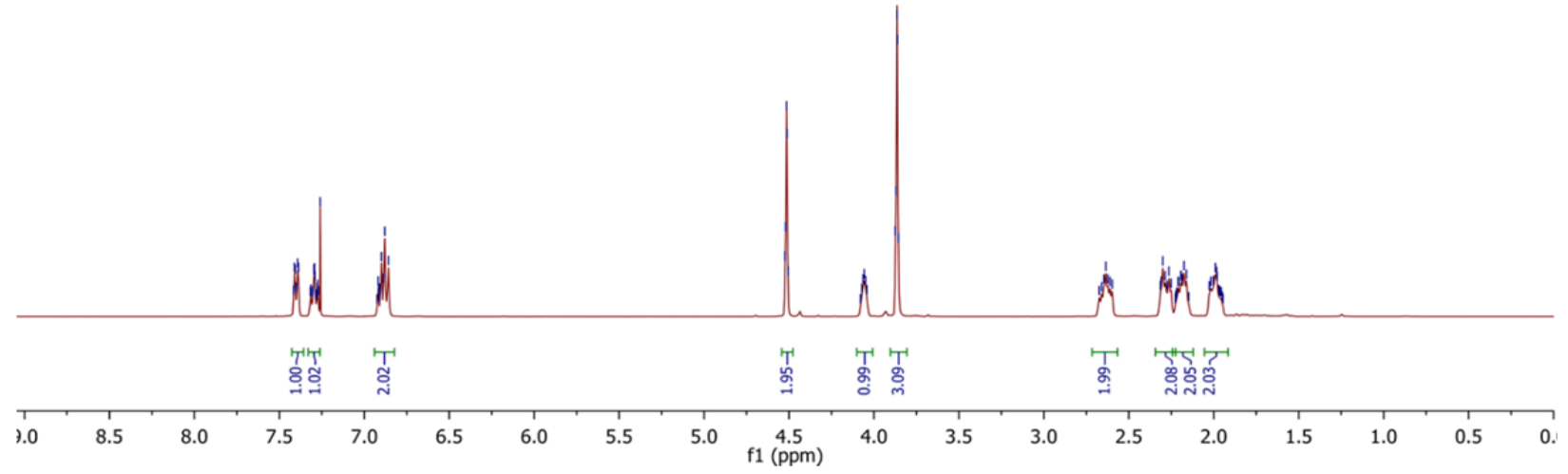

dong-pof - sm-o-ome.11.fid

$\stackrel{\text { I }}{\text { I }}$

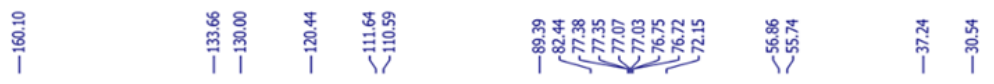

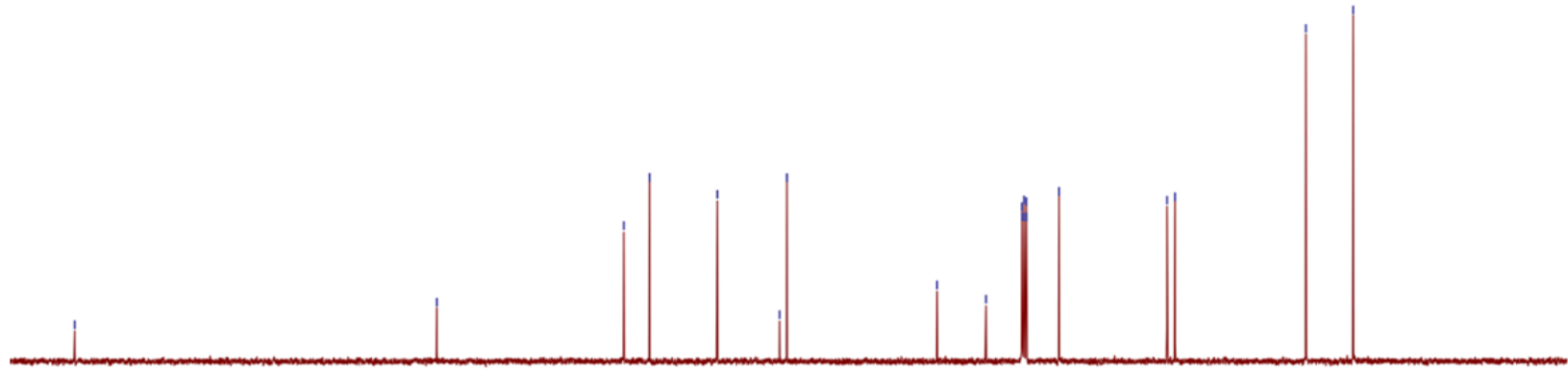

$\begin{array}{lllllllllllllllllllllll}20 & 210 & 200 & 190 & 180 & 170 & 160 & 150 & 140 & 130 & 120 & 110 & 100 & 90 & 80 & 70 & 60 & 50 & 40 & 30 & 20 & 10 & \end{array}$ S72 

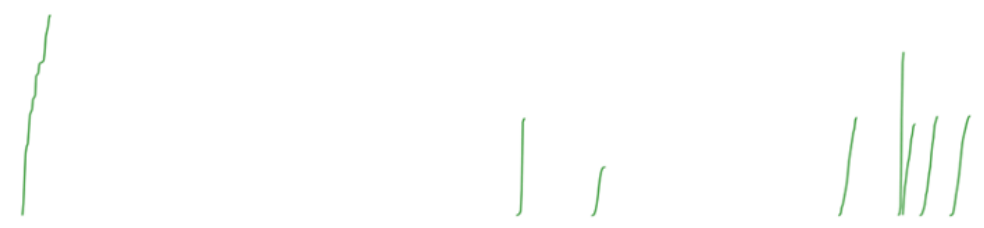<smiles>Cc1cccc(C#CCOC2CCC(=O)CC2)c1</smiles>
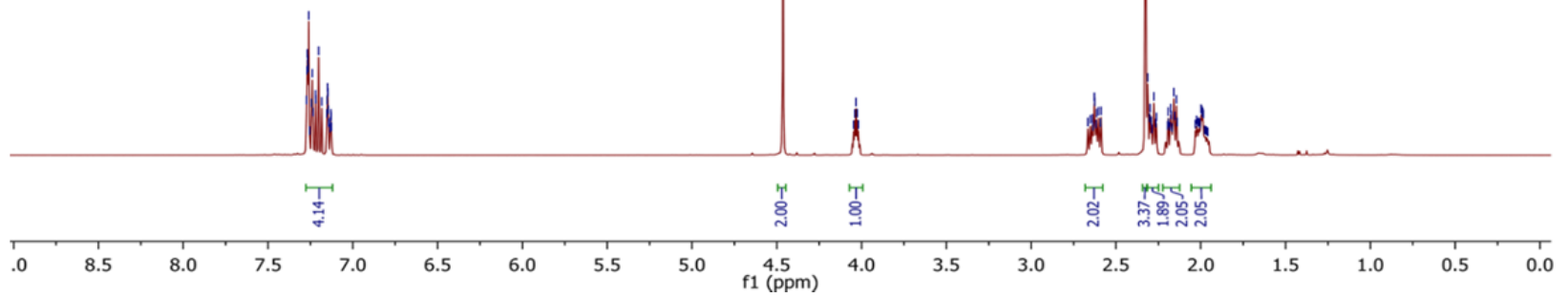
dong-gf-sm-m-m.10.fid
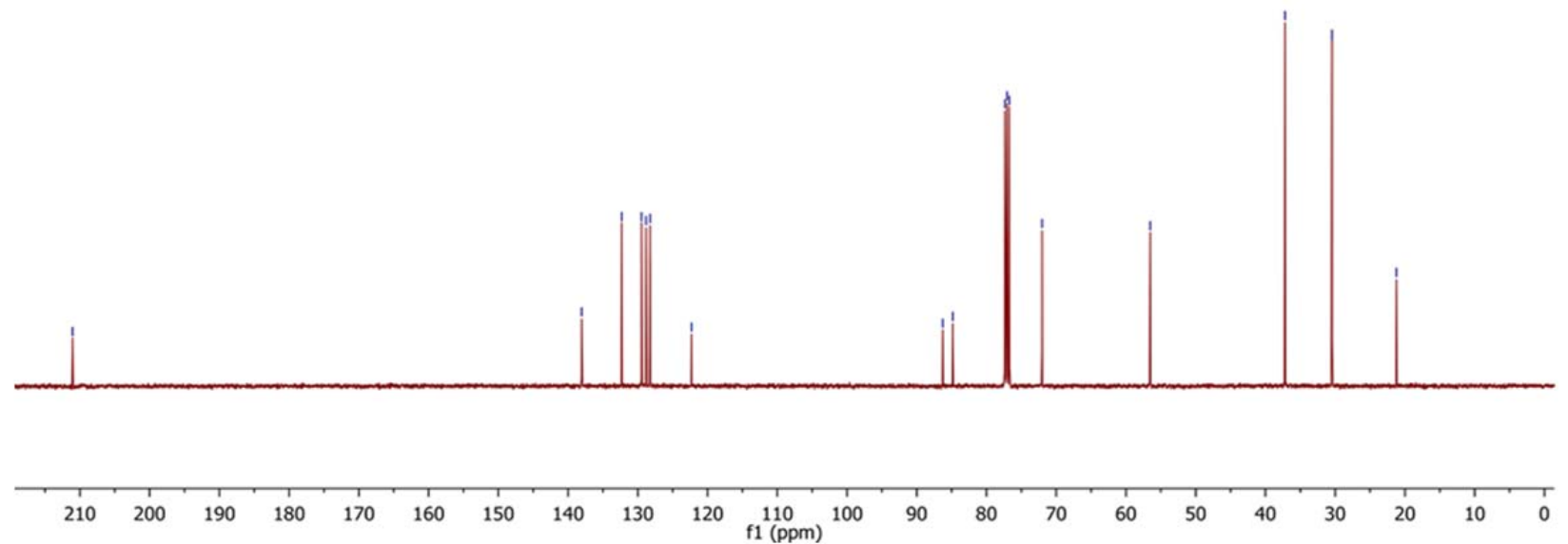


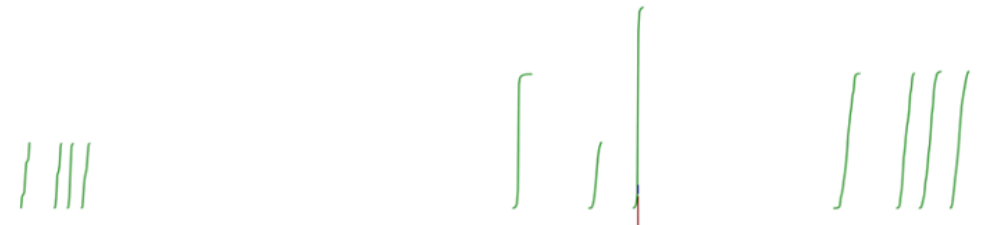<smiles>COc1cccc(C#CCOC2CCC(=O)CC2)c1</smiles>

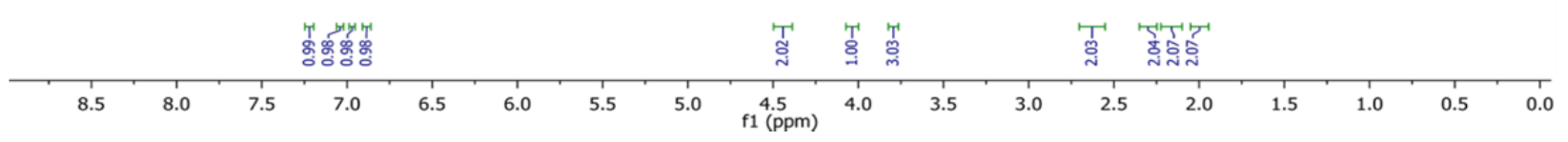

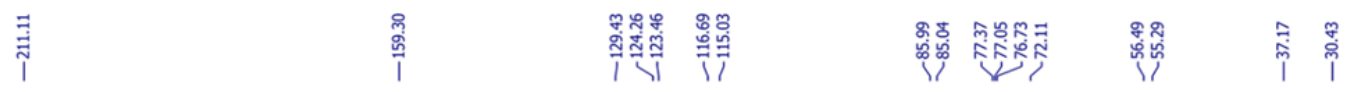

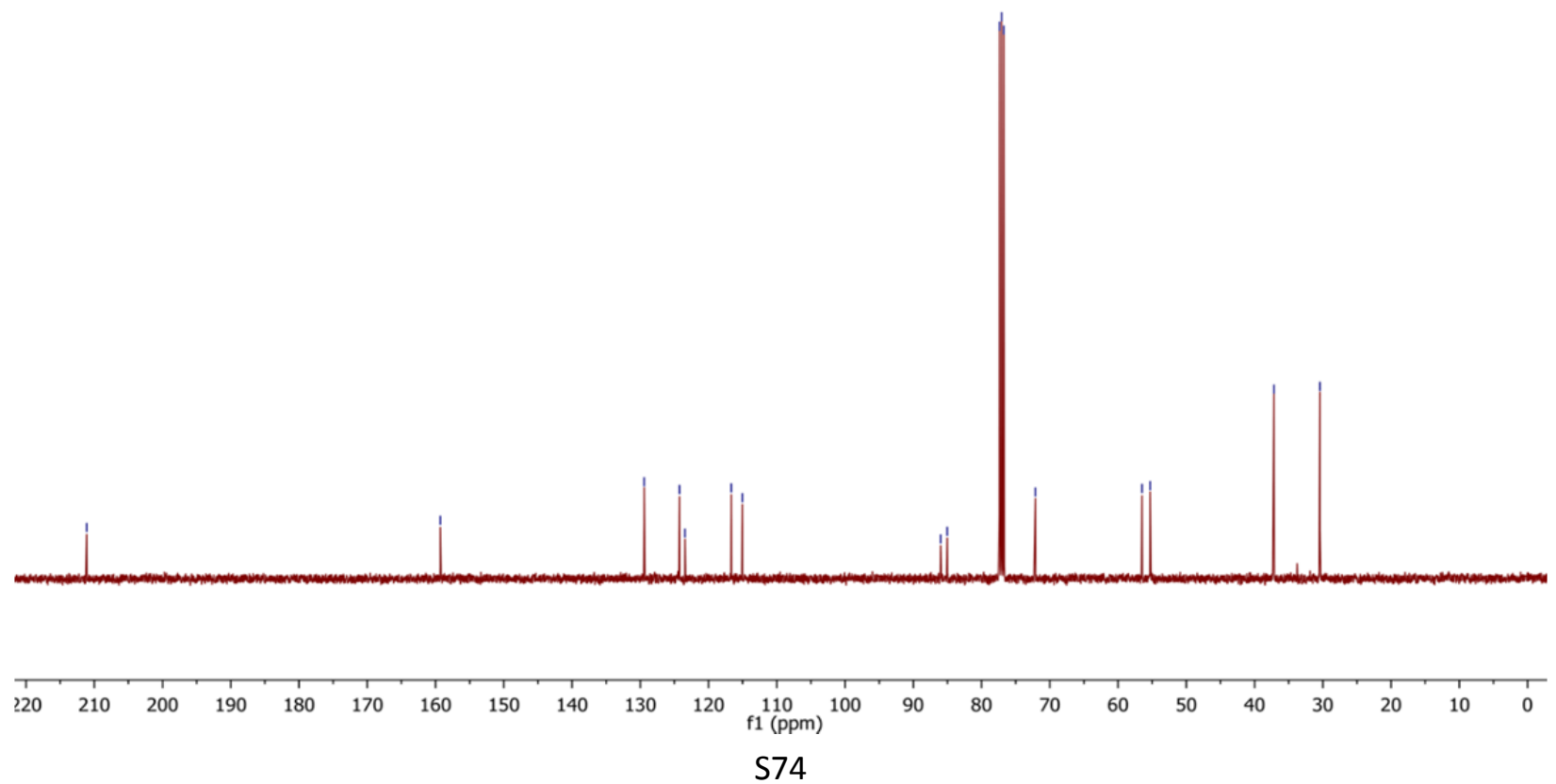



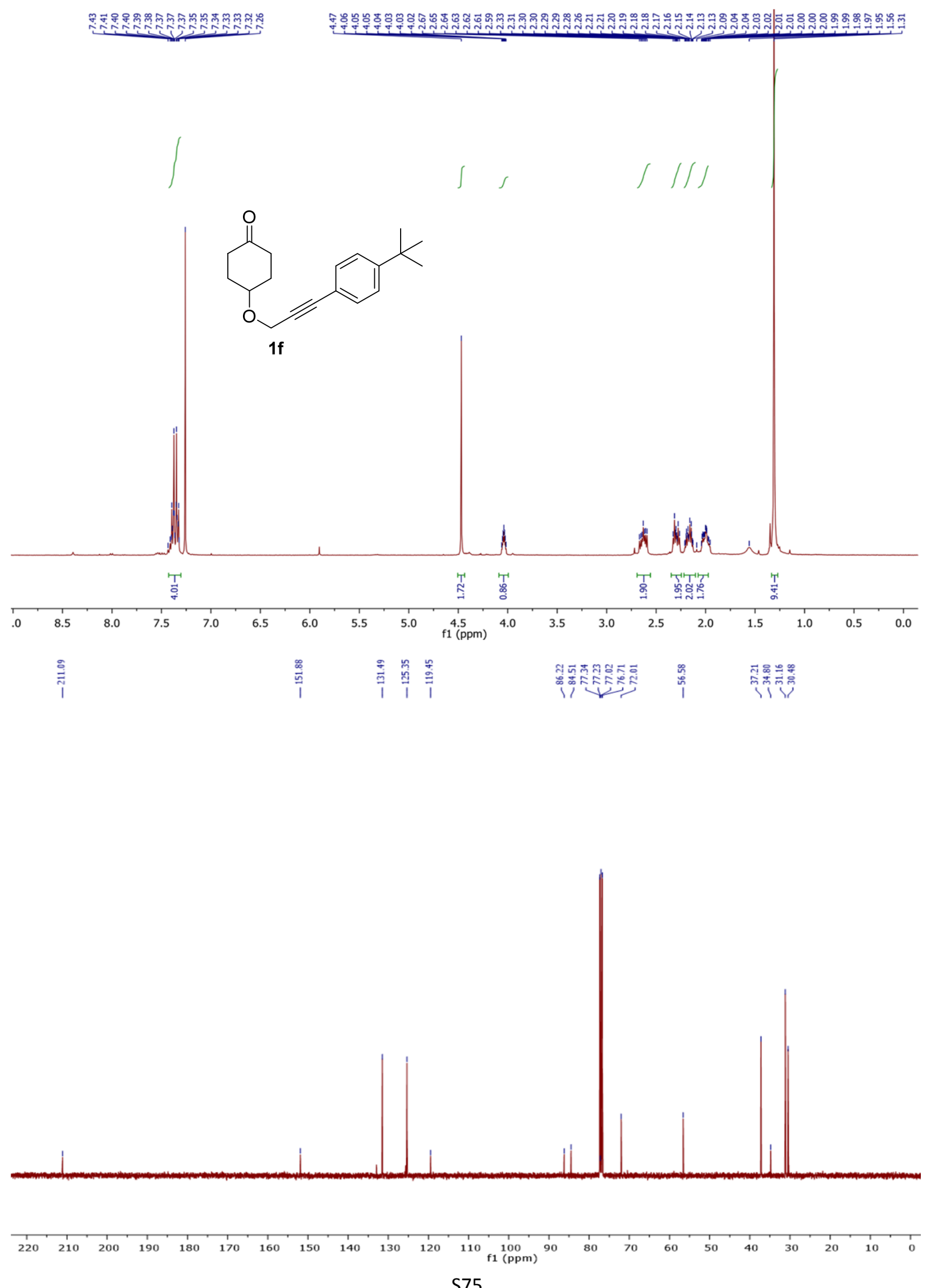


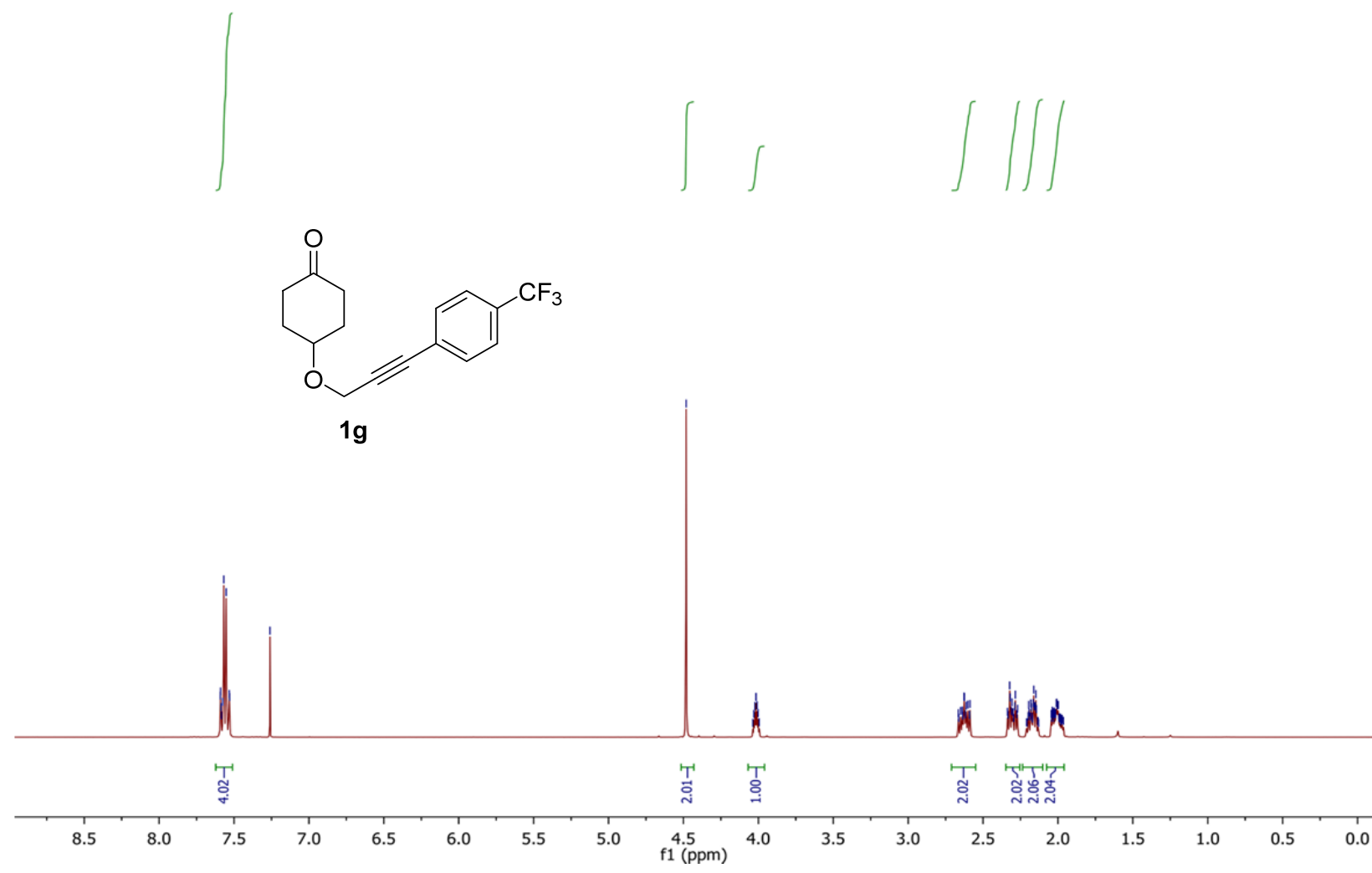

dong-pf-spo-p-cf3.11.fid

†

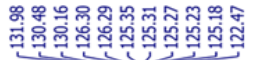

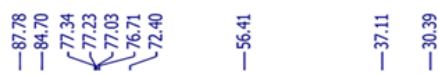
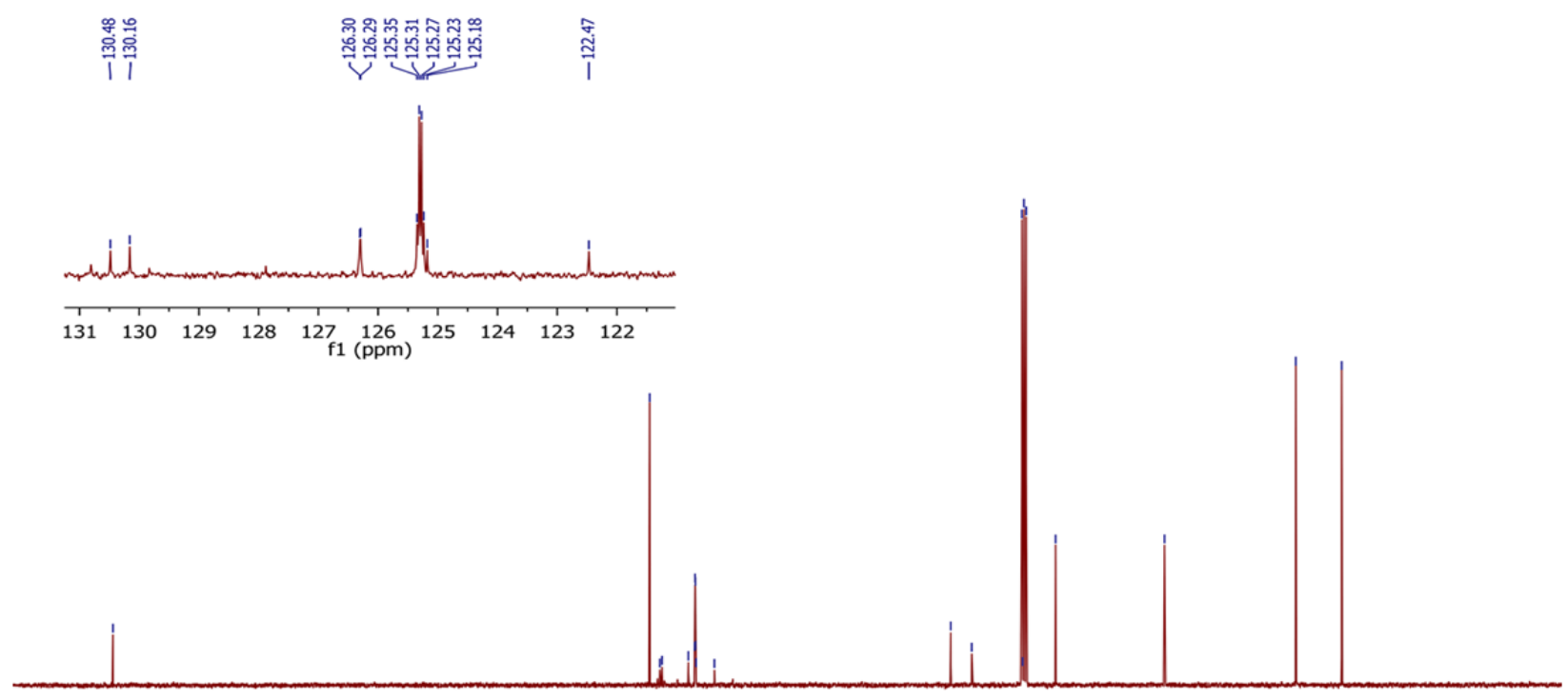

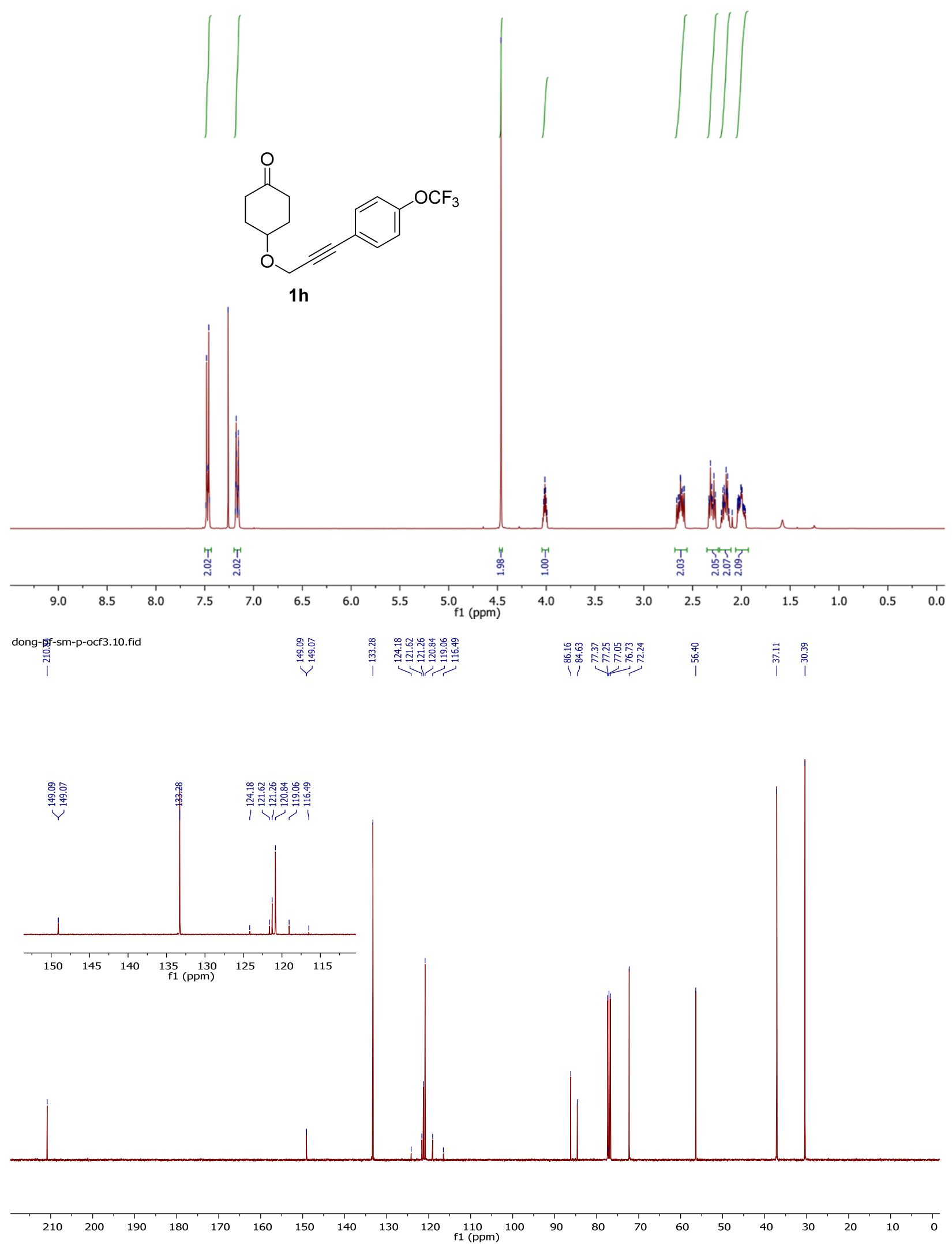

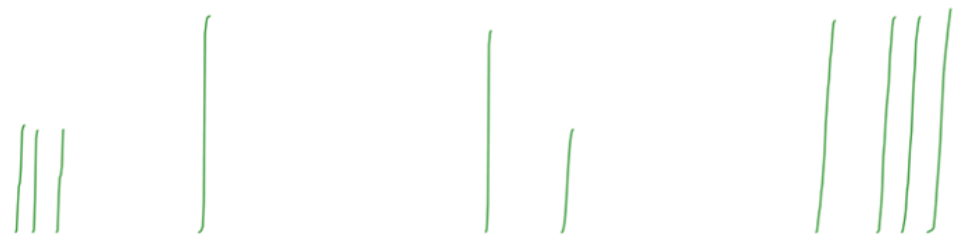<smiles>O=C1CCC(OCC#Cc2ccc(F)cc2)CC1</smiles>

$1 i$

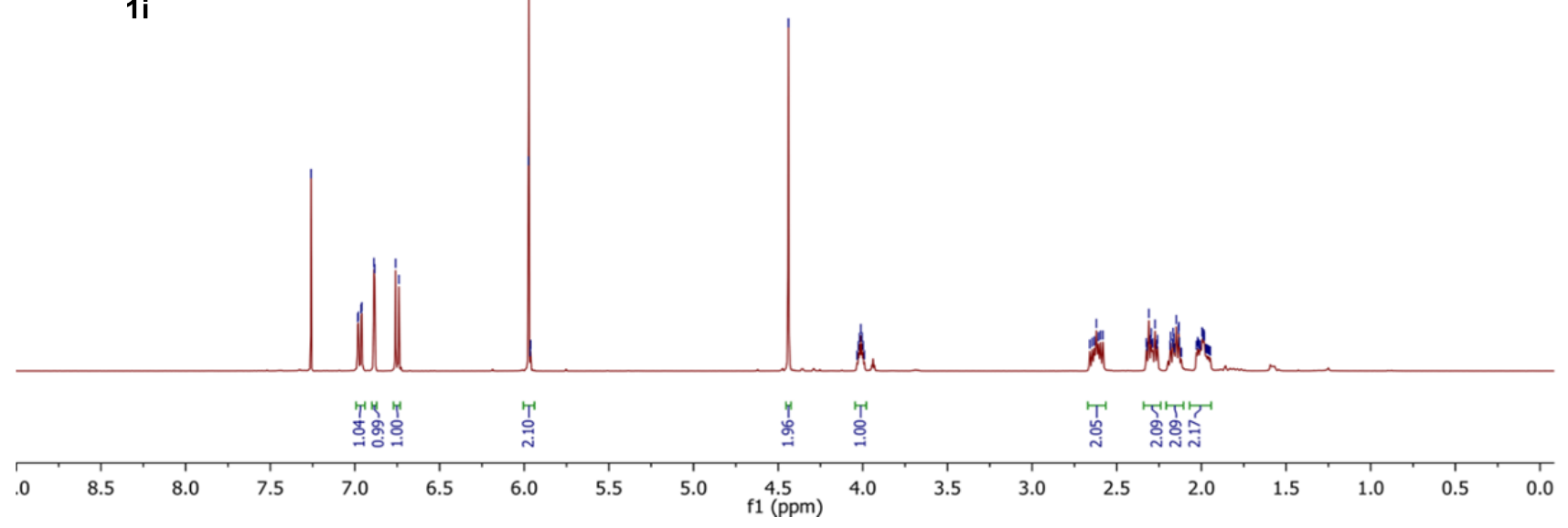
dong-pf-39108.20.fid iี

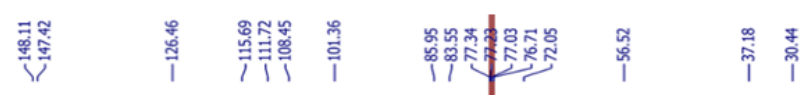

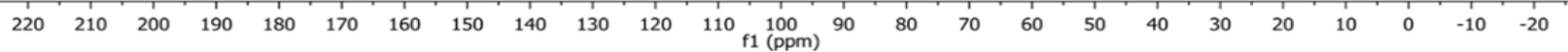
S78 

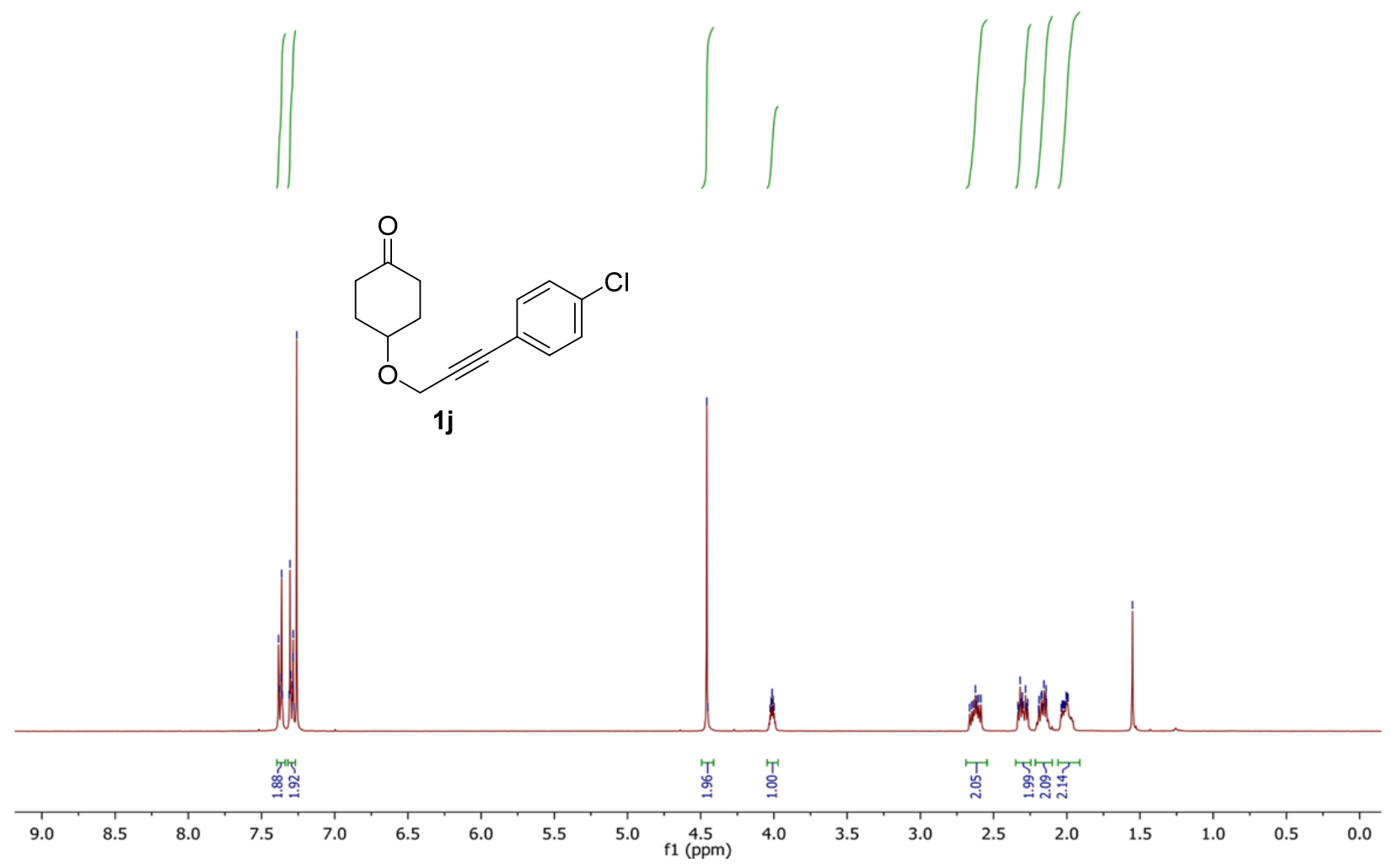

dong-pf-3-210-10nn.10.fid ก
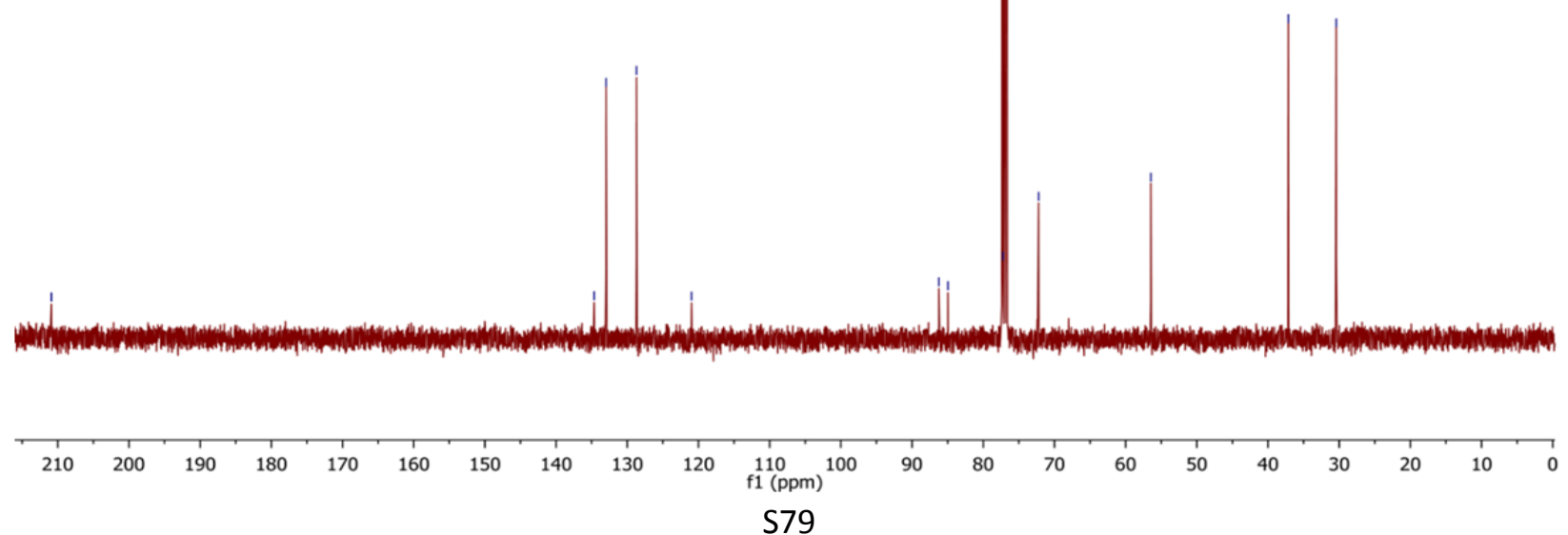

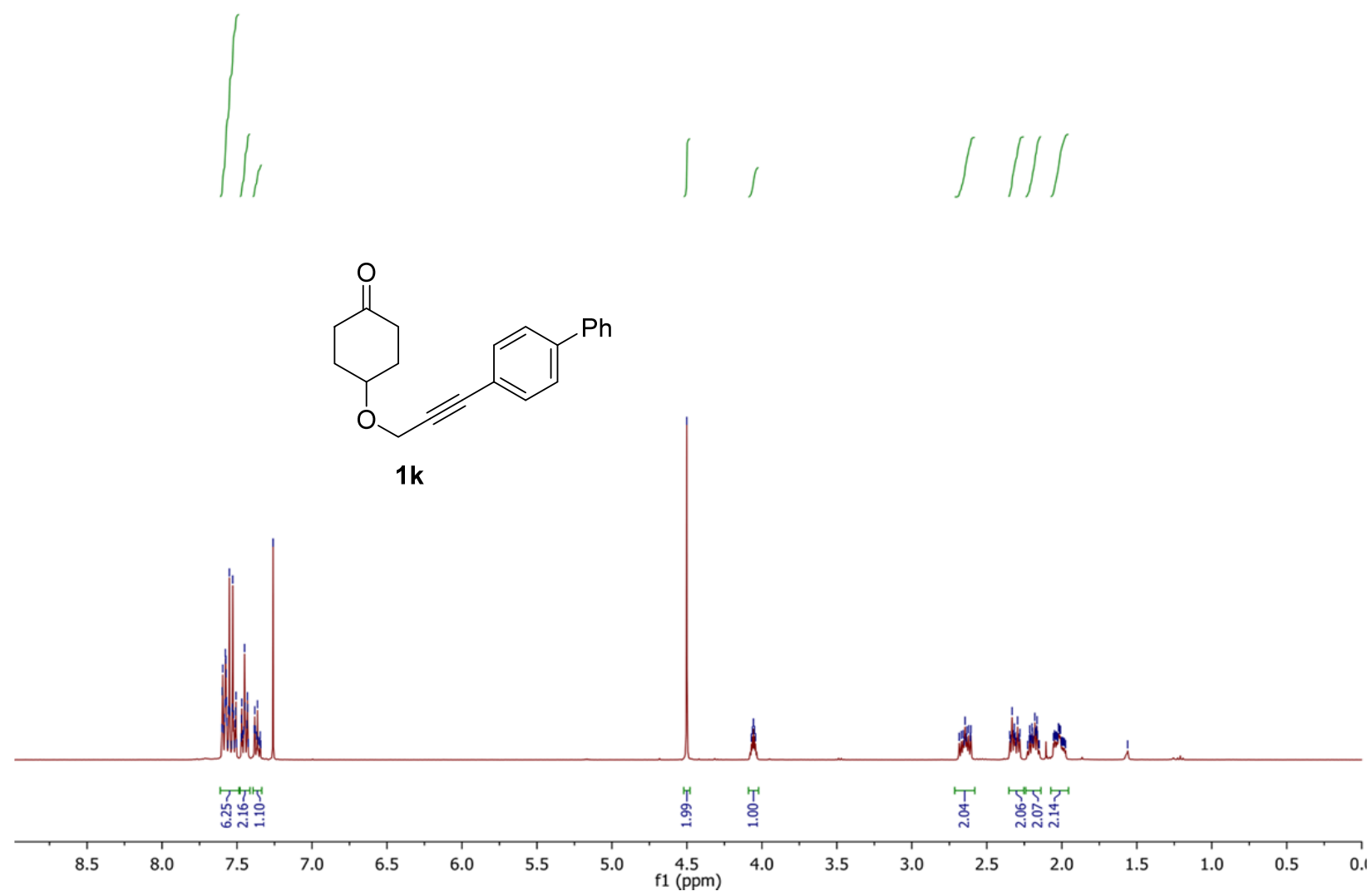

dong-pgrsm-p-ph.11.fid

†

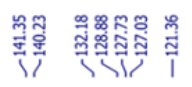

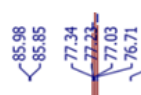

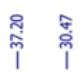
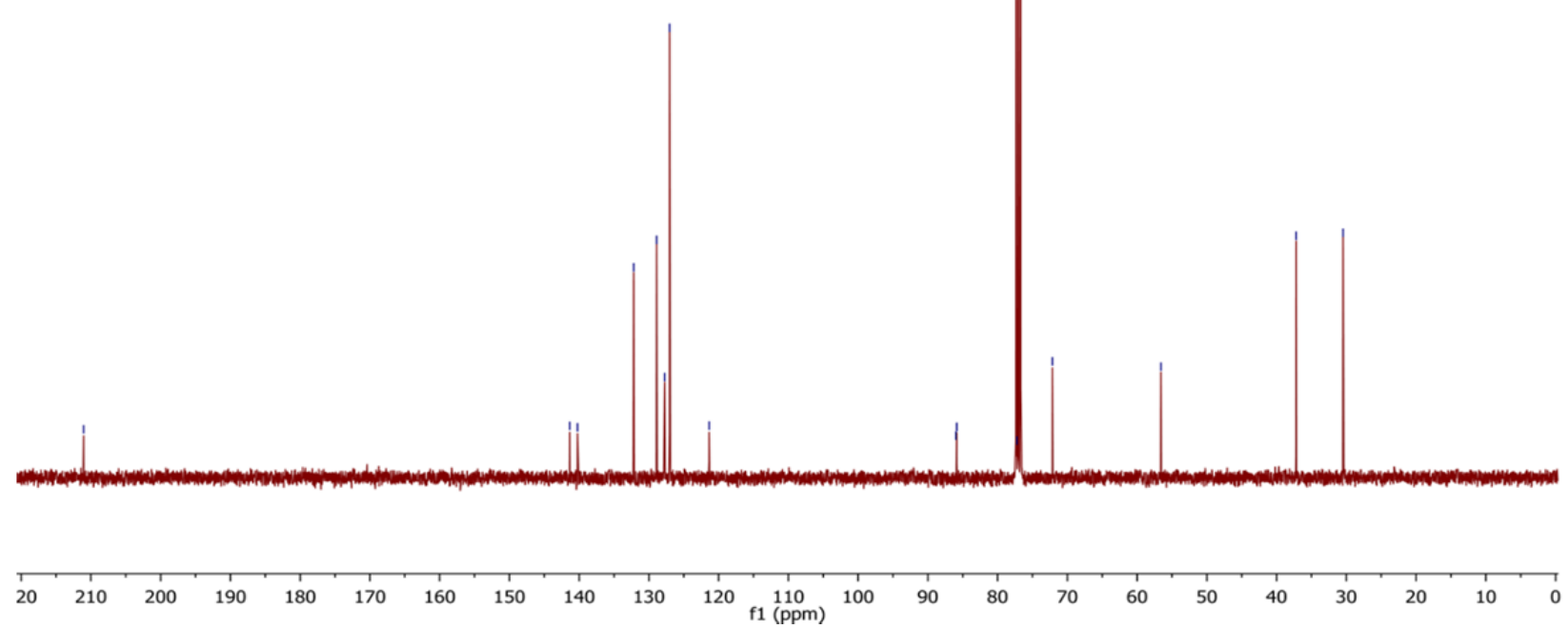

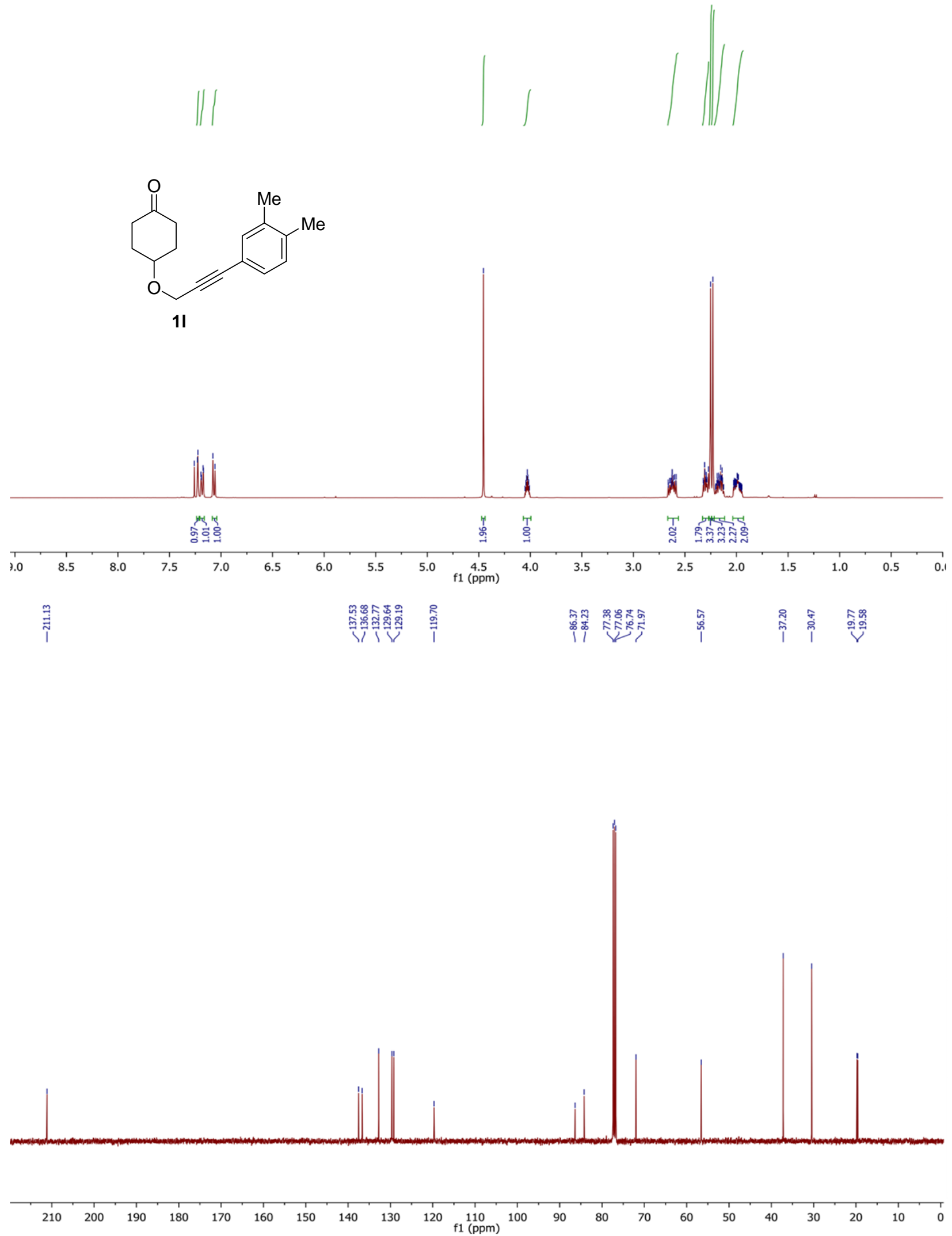

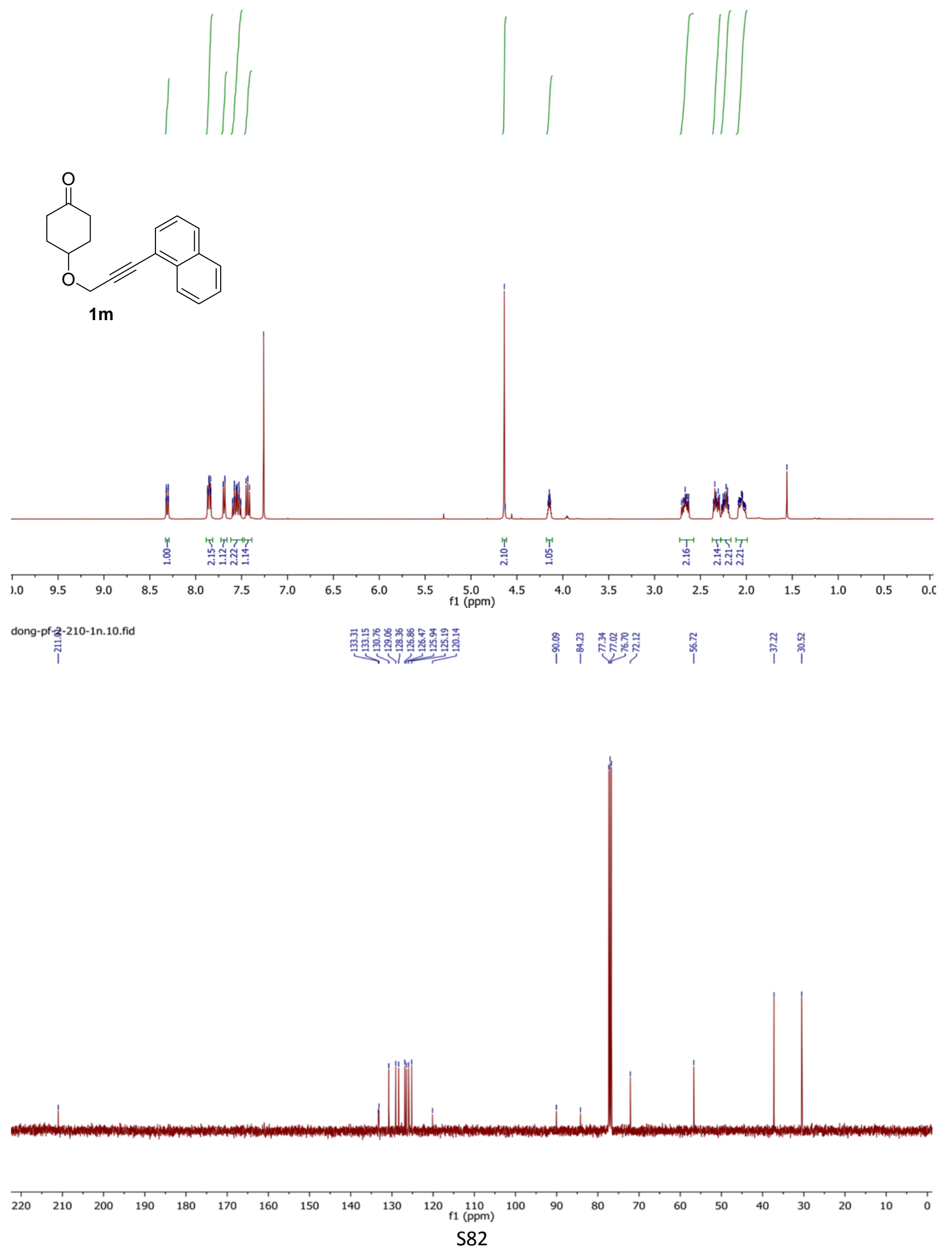


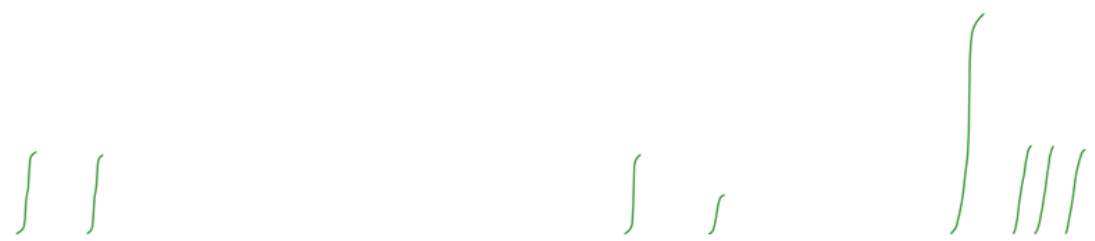<smiles>CC(=O)c1ccc(C#CCOC2CCC(=O)CC2)cc1</smiles>

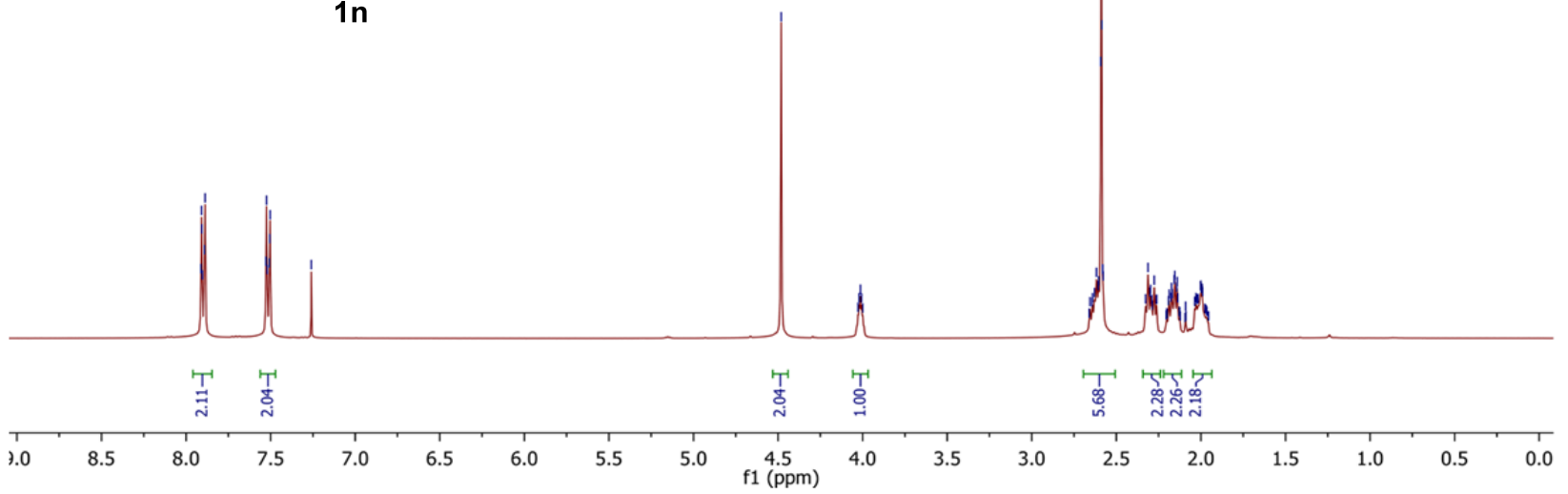
dong-pofs-sm-p-ketane.11.fid iิ

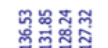
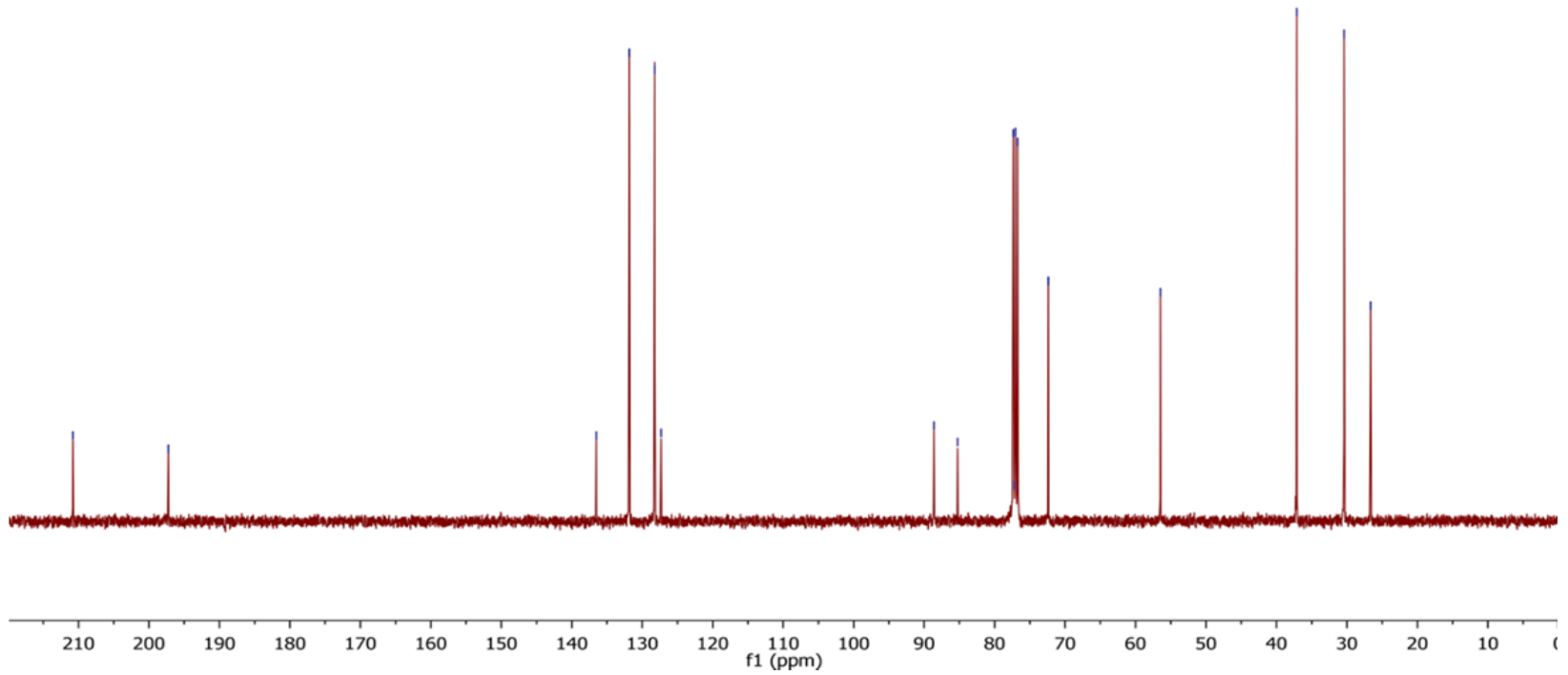


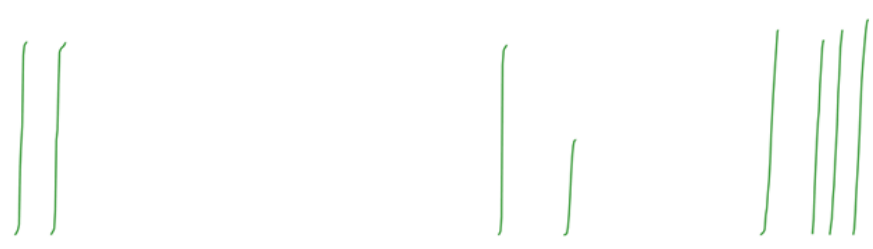<smiles>O=Cc1ccc(C#CCOC2CCC(=O)CC2)cc1</smiles>

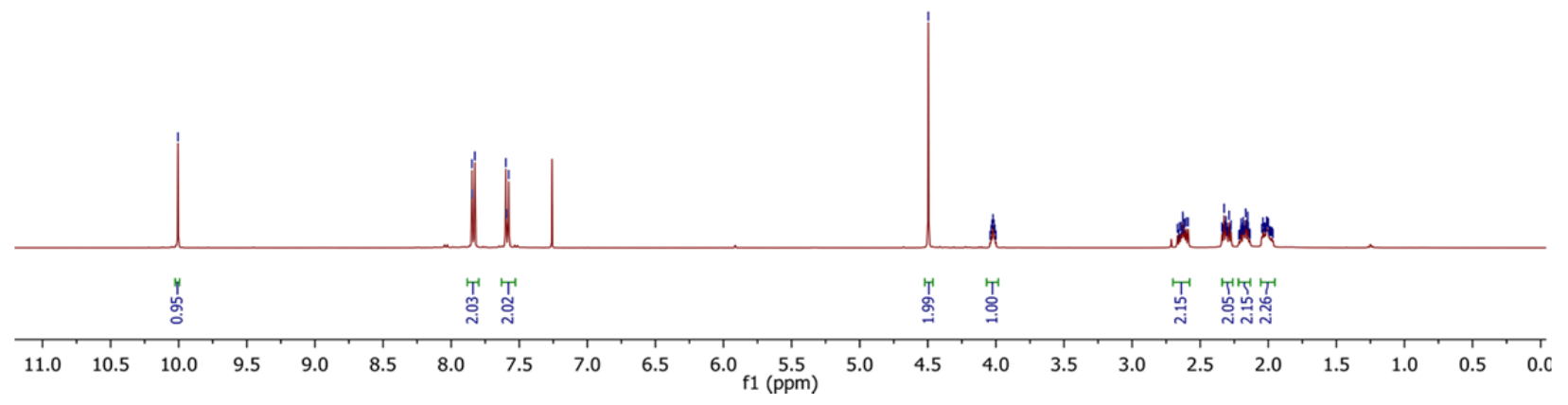

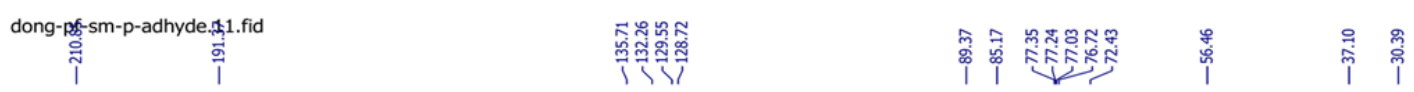

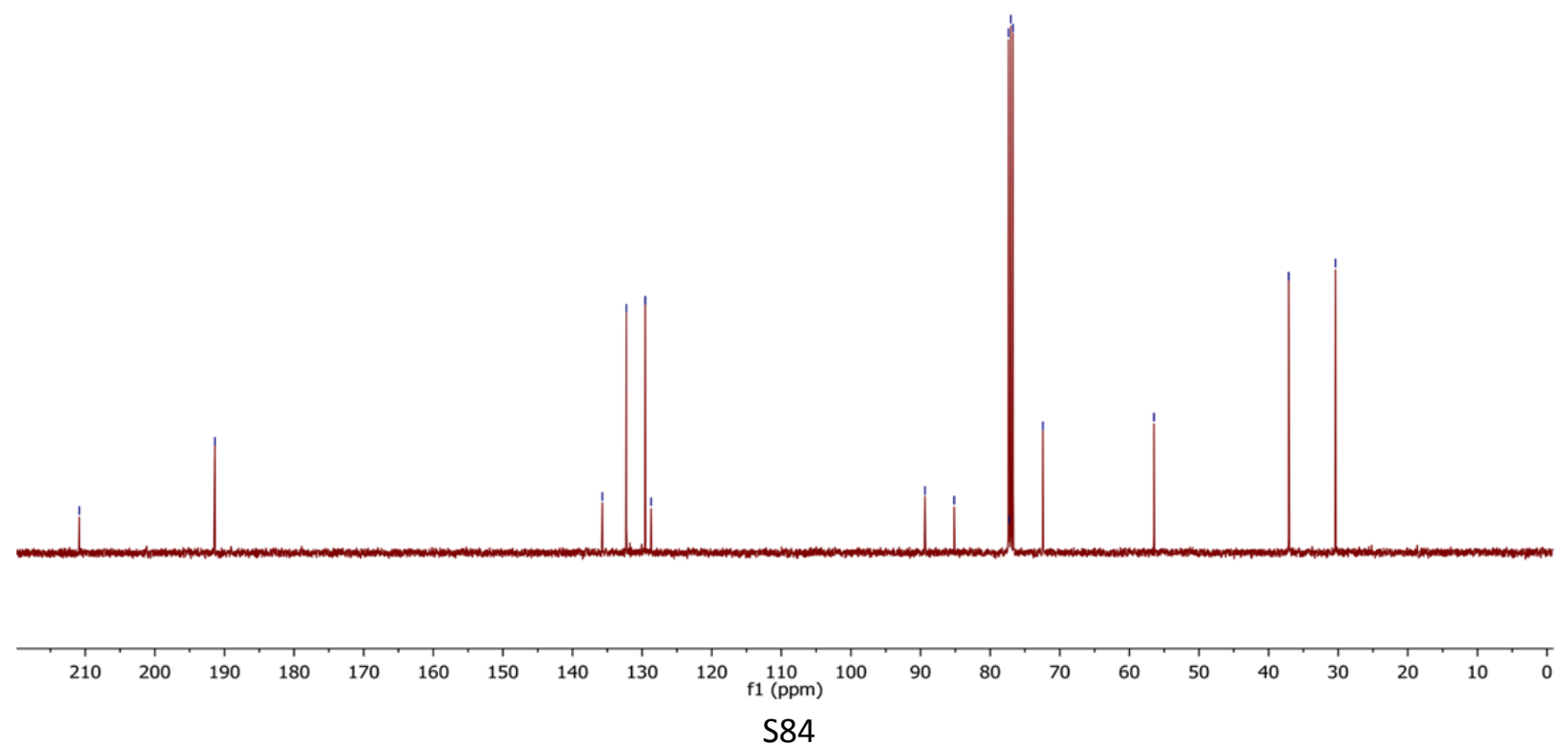




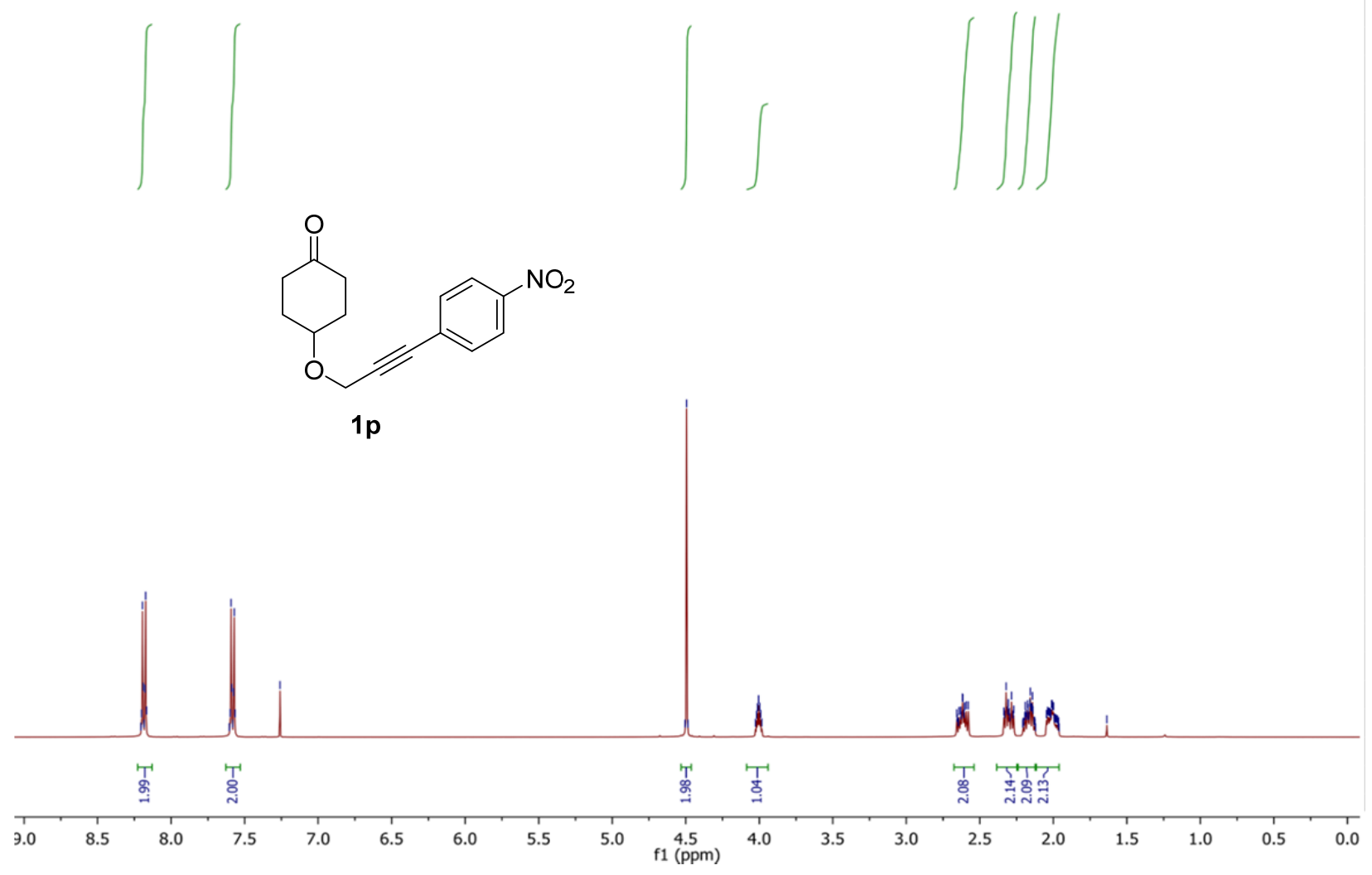

\begin{tabular}{|c|c|}
\hline & $\vec{\imath} \vec{i} \vec{\imath}$ \\
\hline 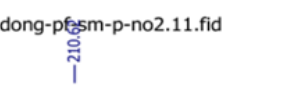 & \\
\hline
\end{tabular}
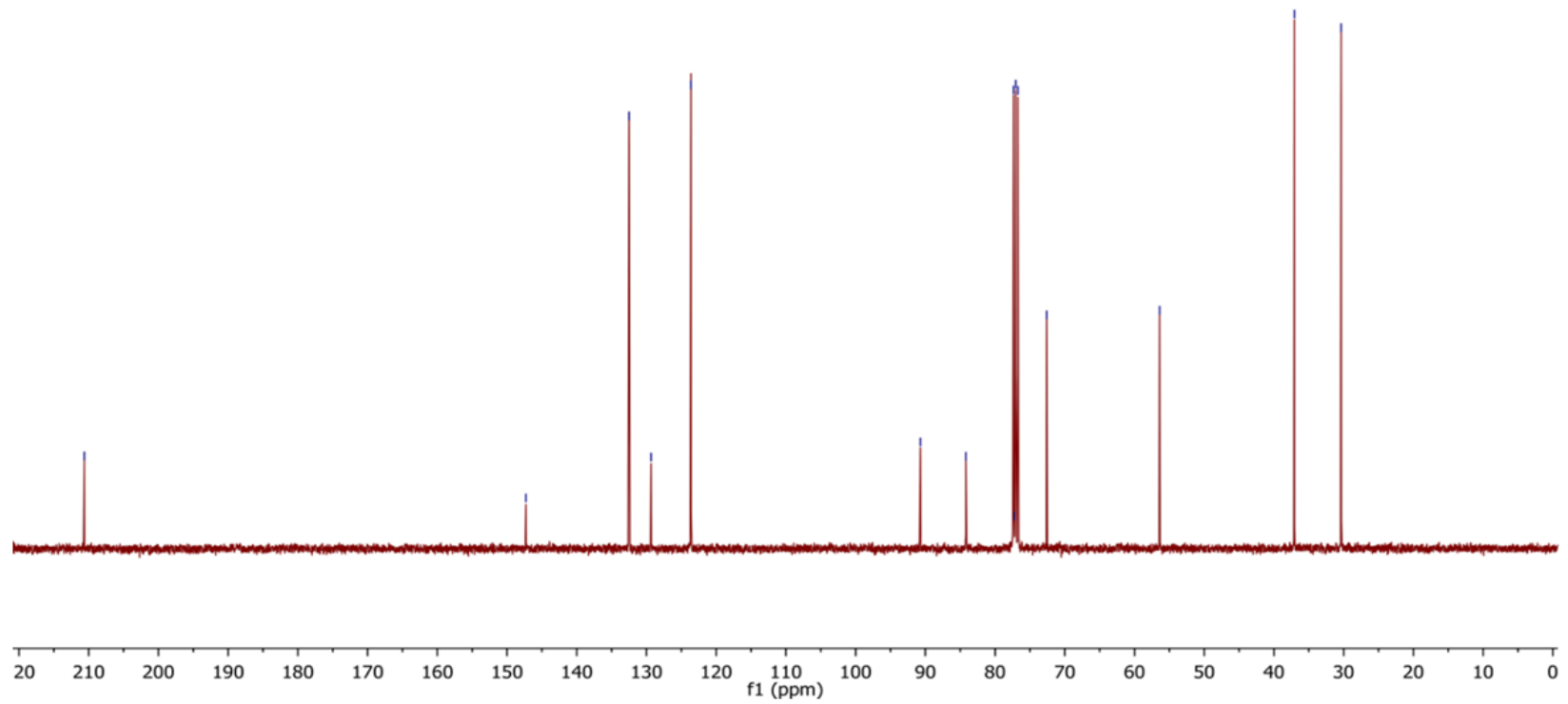


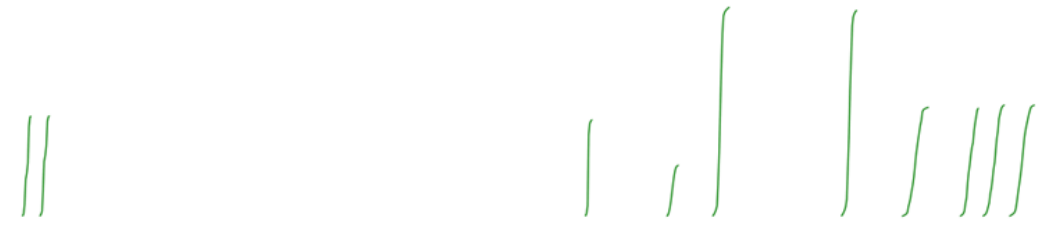<smiles>O=C1CCC(OCC#Cc2ccc(S(=O)(=O)N3CCOCC3)cc2)CC1</smiles>

1q
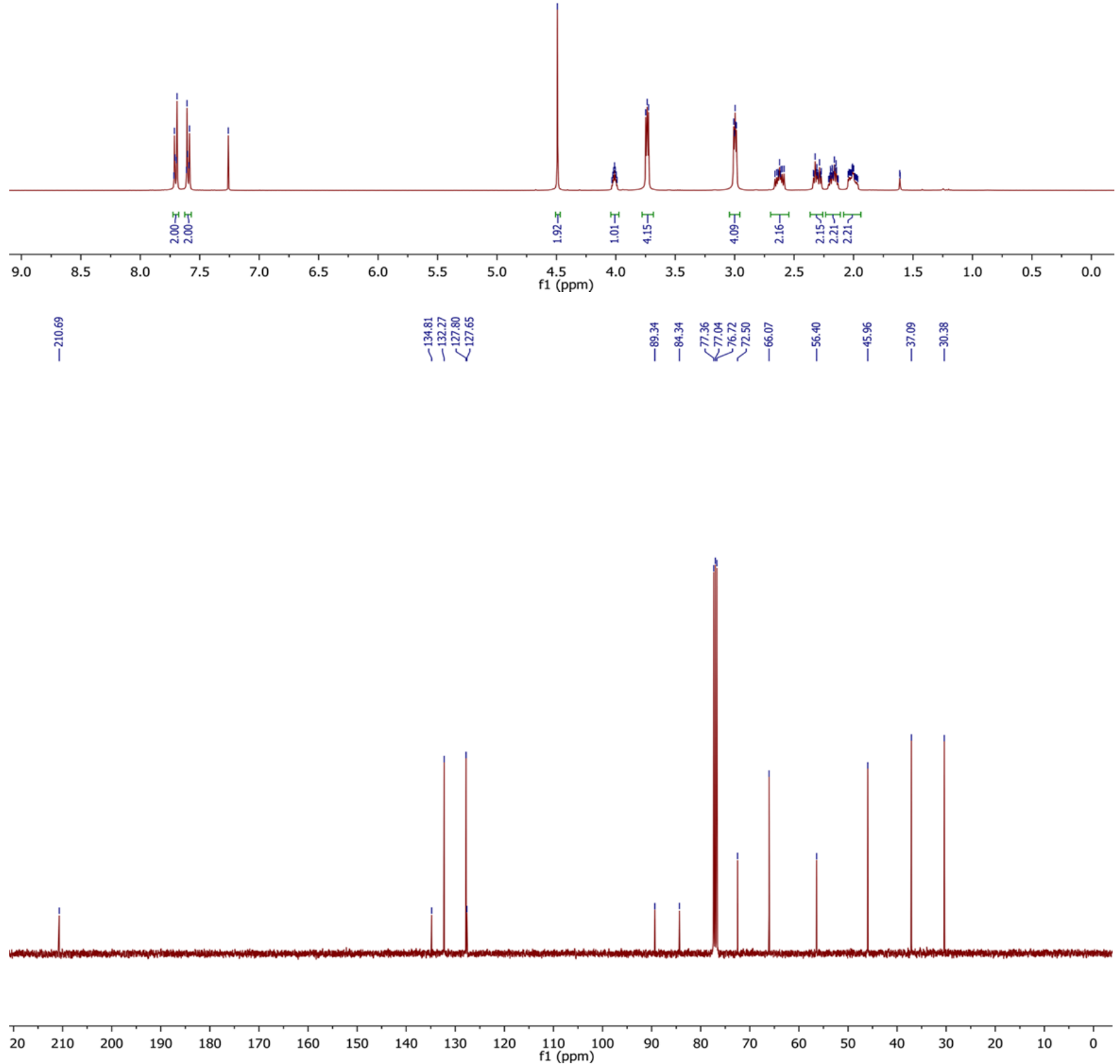

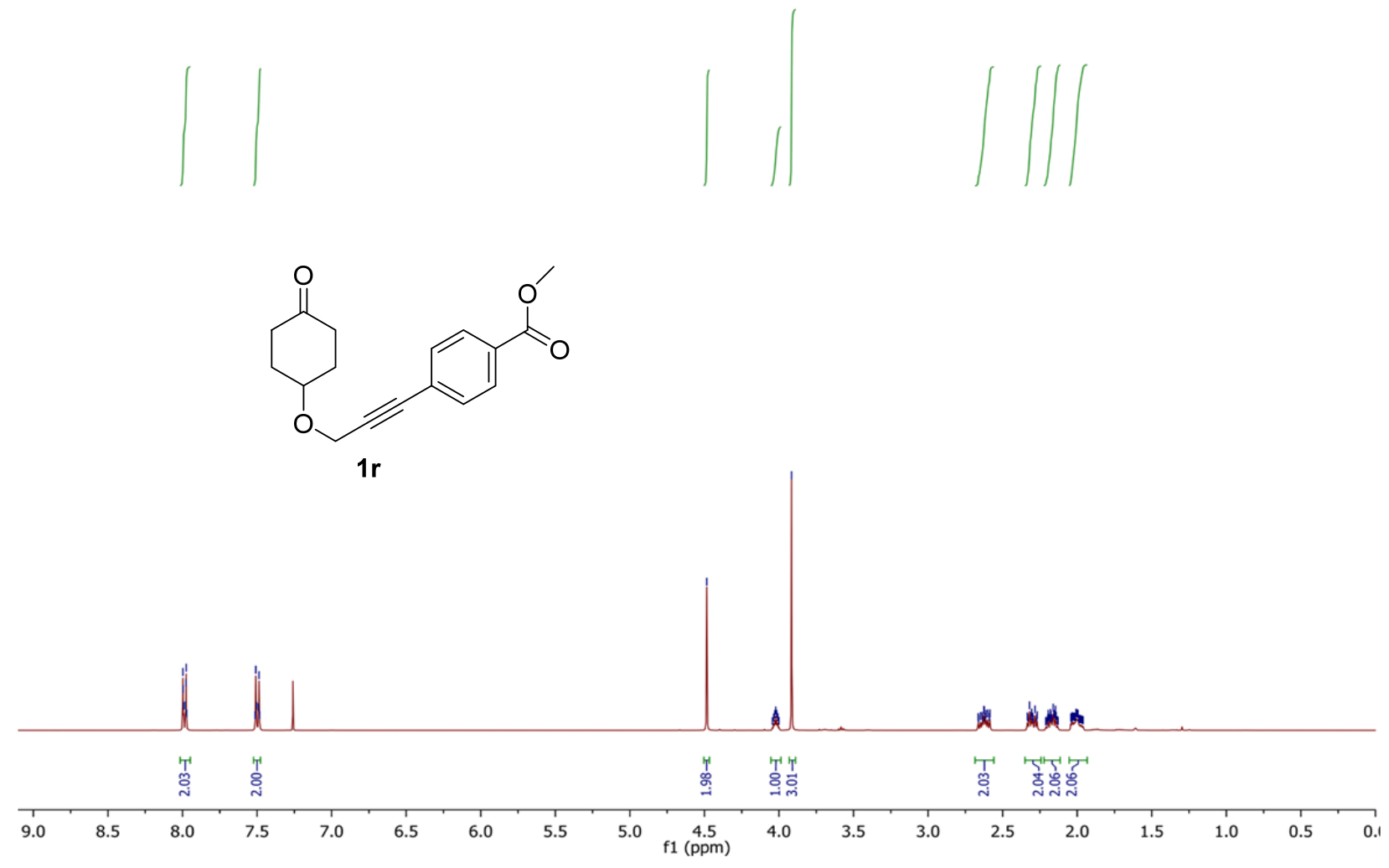

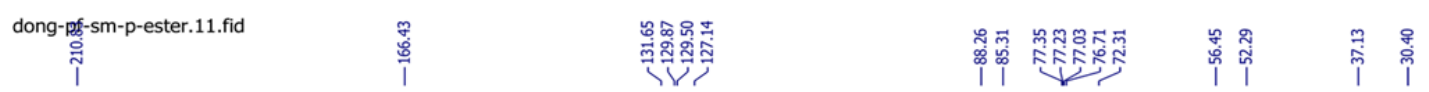
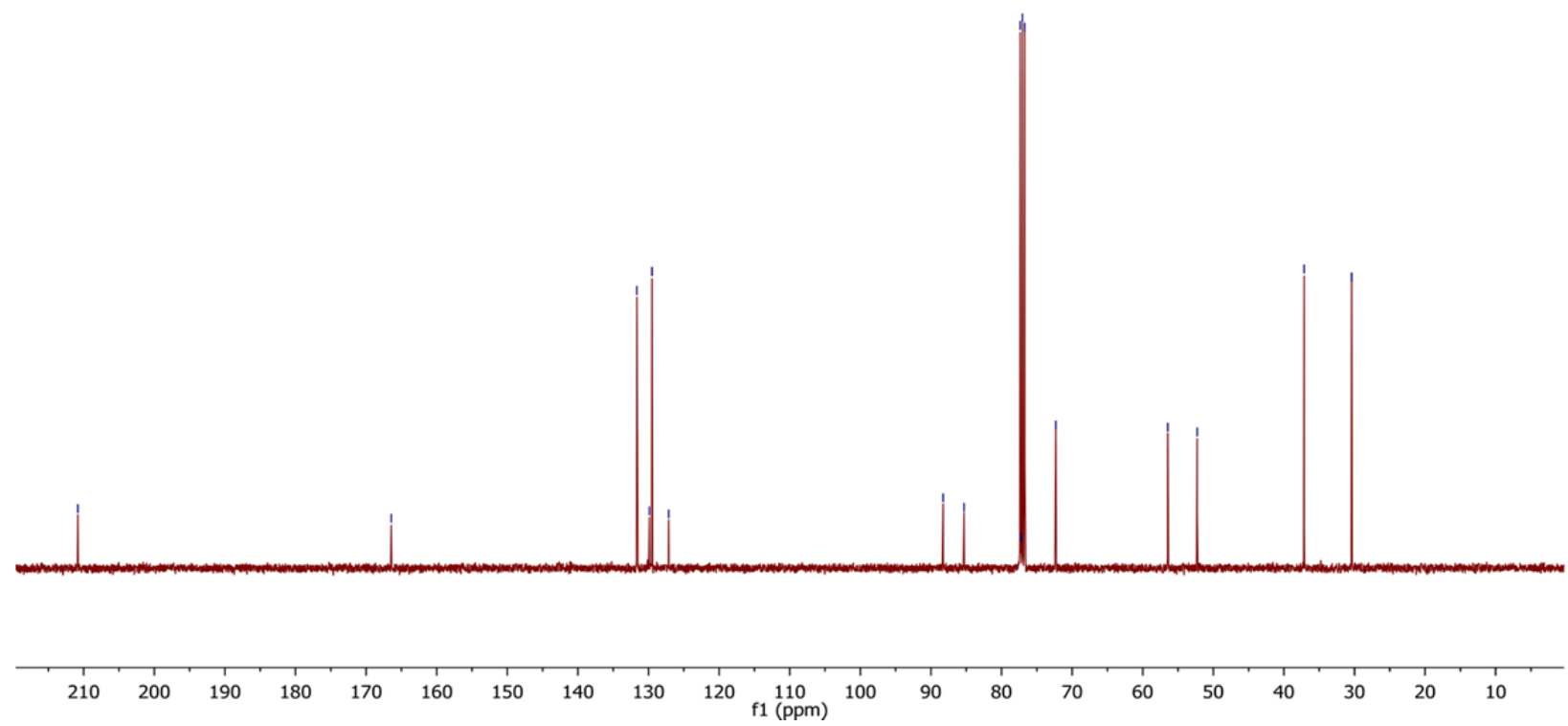


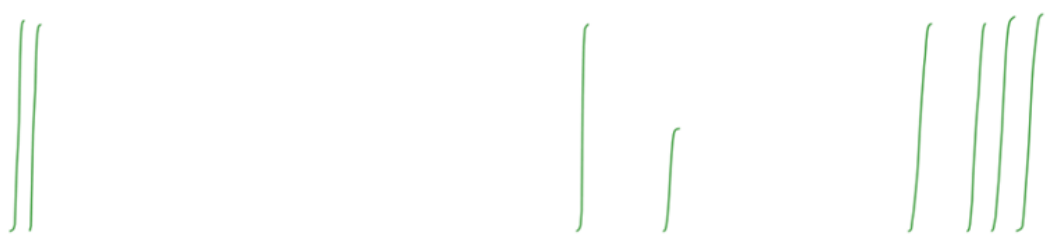<smiles>N#Cc1ccc(C#CCOC2CCC(=O)CC2)cc1</smiles>
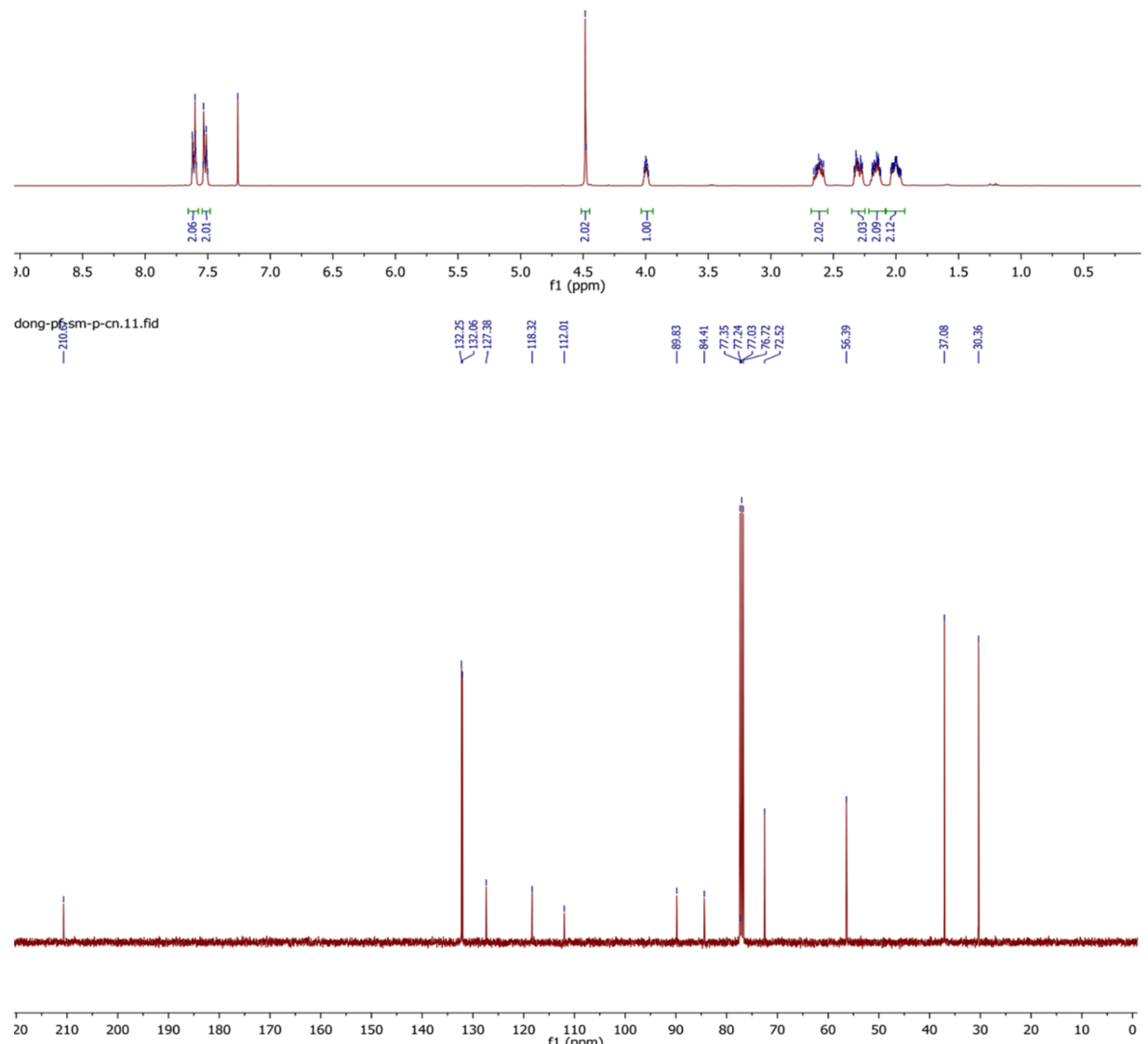
<smiles>CC(F)(F)Oc1cccc(C#CCOC2CCC(=O)CC2)c1</smiles>

1t

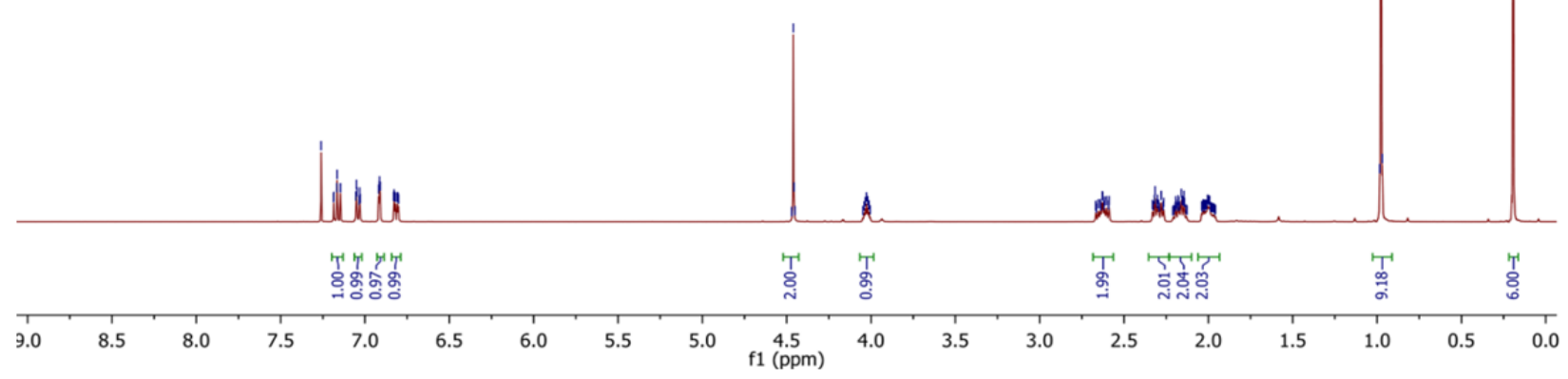

dong-pf-sm-m-tbs.11.fid \.

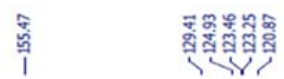
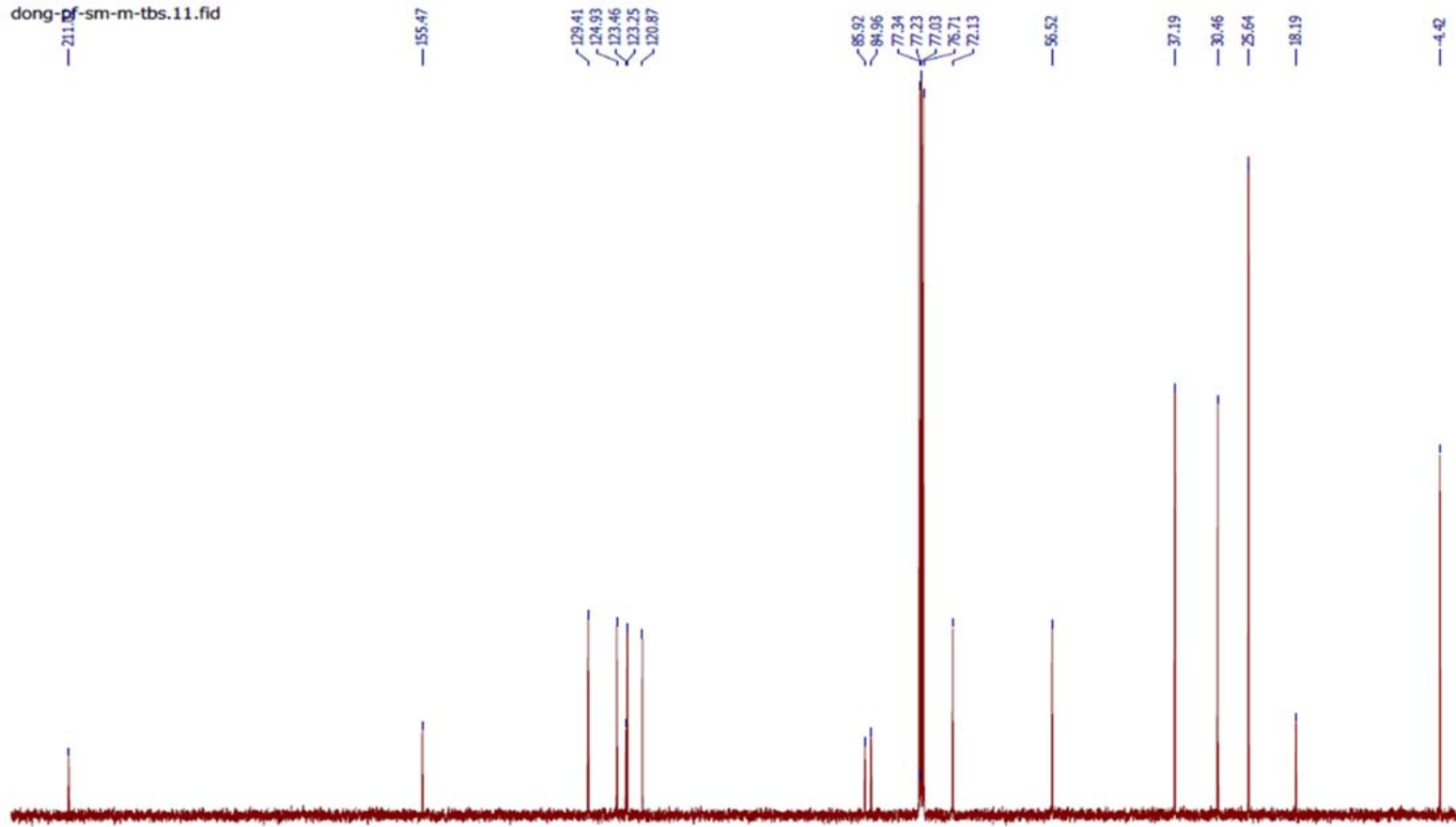

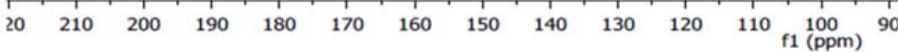

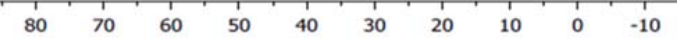




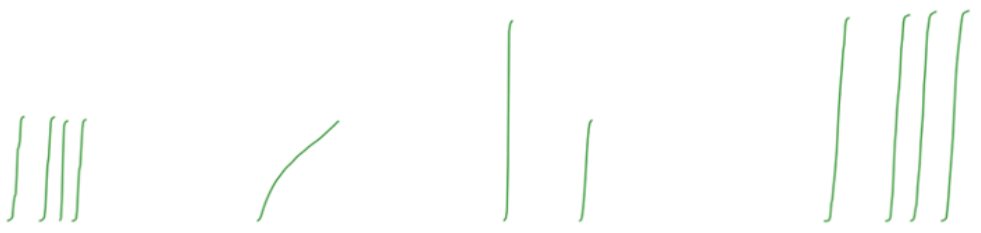<smiles>O=C1CCC(OCC#Cc2cccc(O)c2)CC1</smiles>

1u

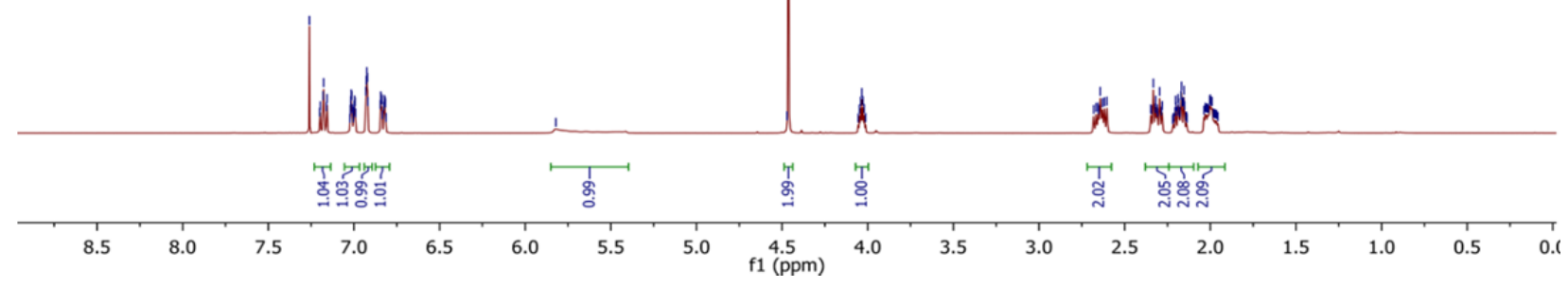

dong-st-sm-mo-oh.10.fid

$\stackrel{\text { กิ }}{\text { I }}$

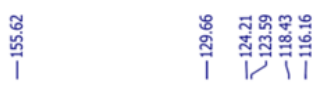

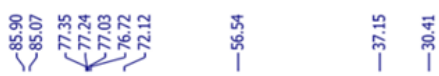

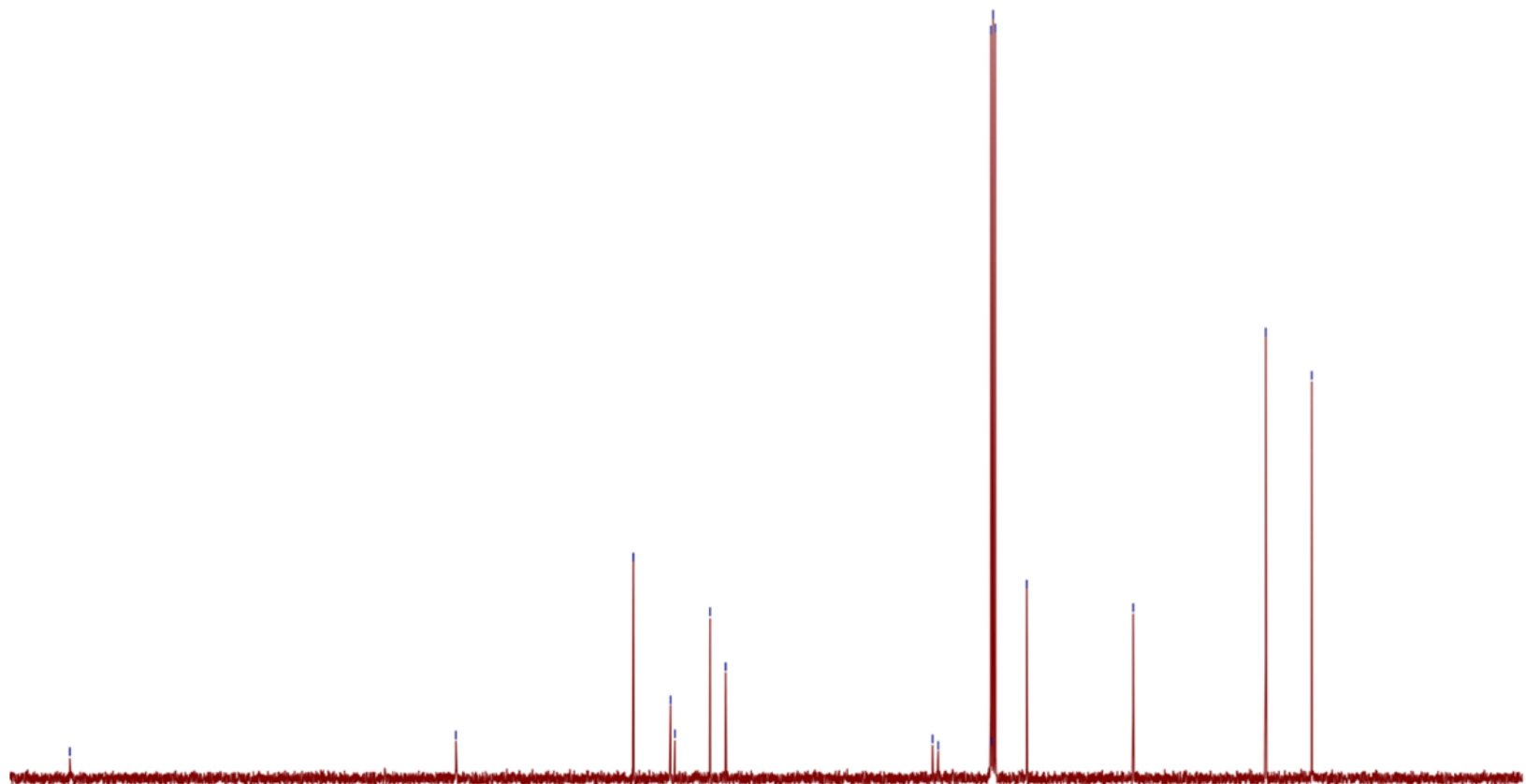

$\begin{array}{lllllllllllllllllllllllll}20 & 210 & 200 & 190 & 180 & 170 & 160 & 150 & 140 & 130 & 120 & 110 & 100 & 90 & 80 & 70 & 60 & 50 & 40 & 30 & 20 & 10 & 0\end{array}$ 

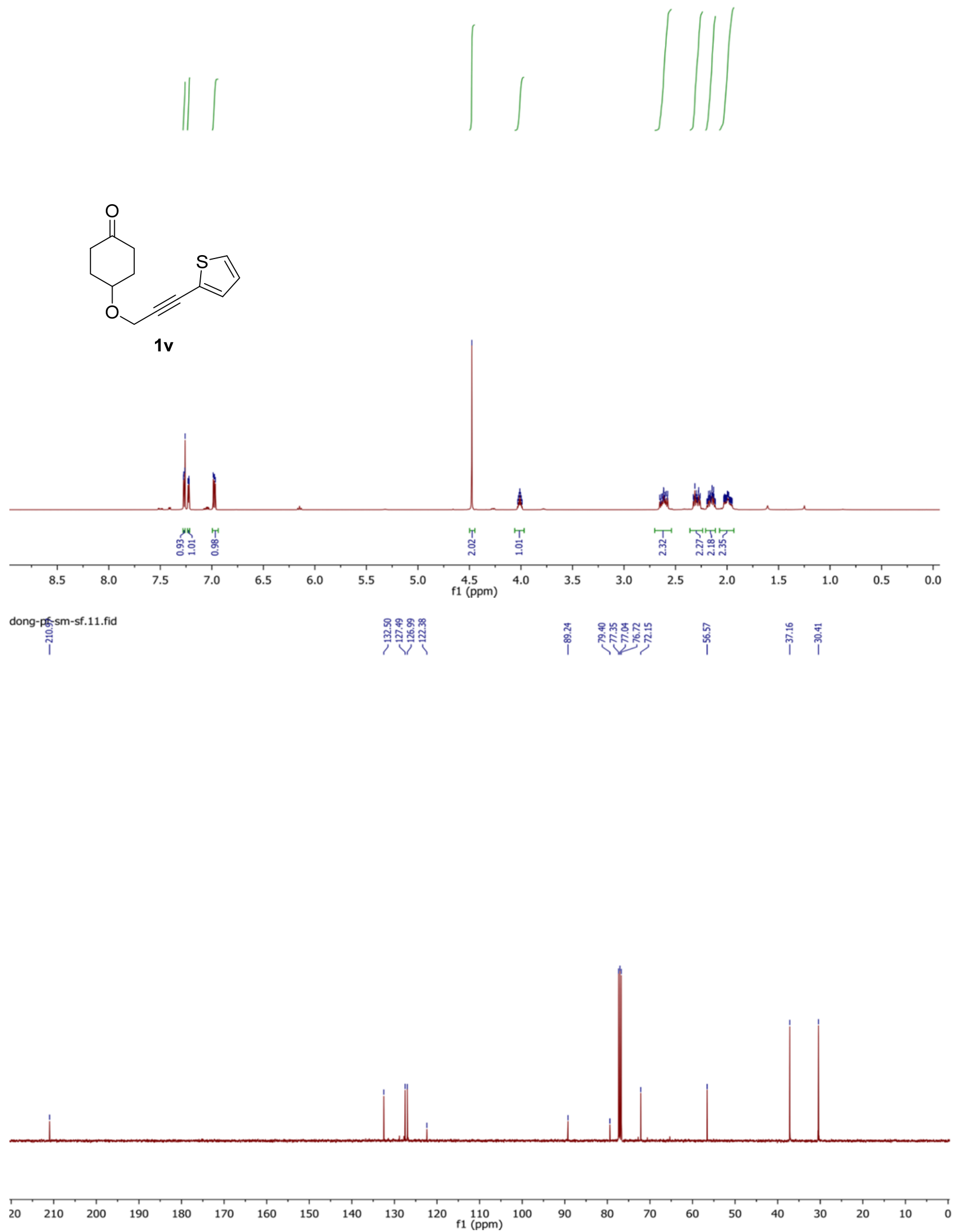

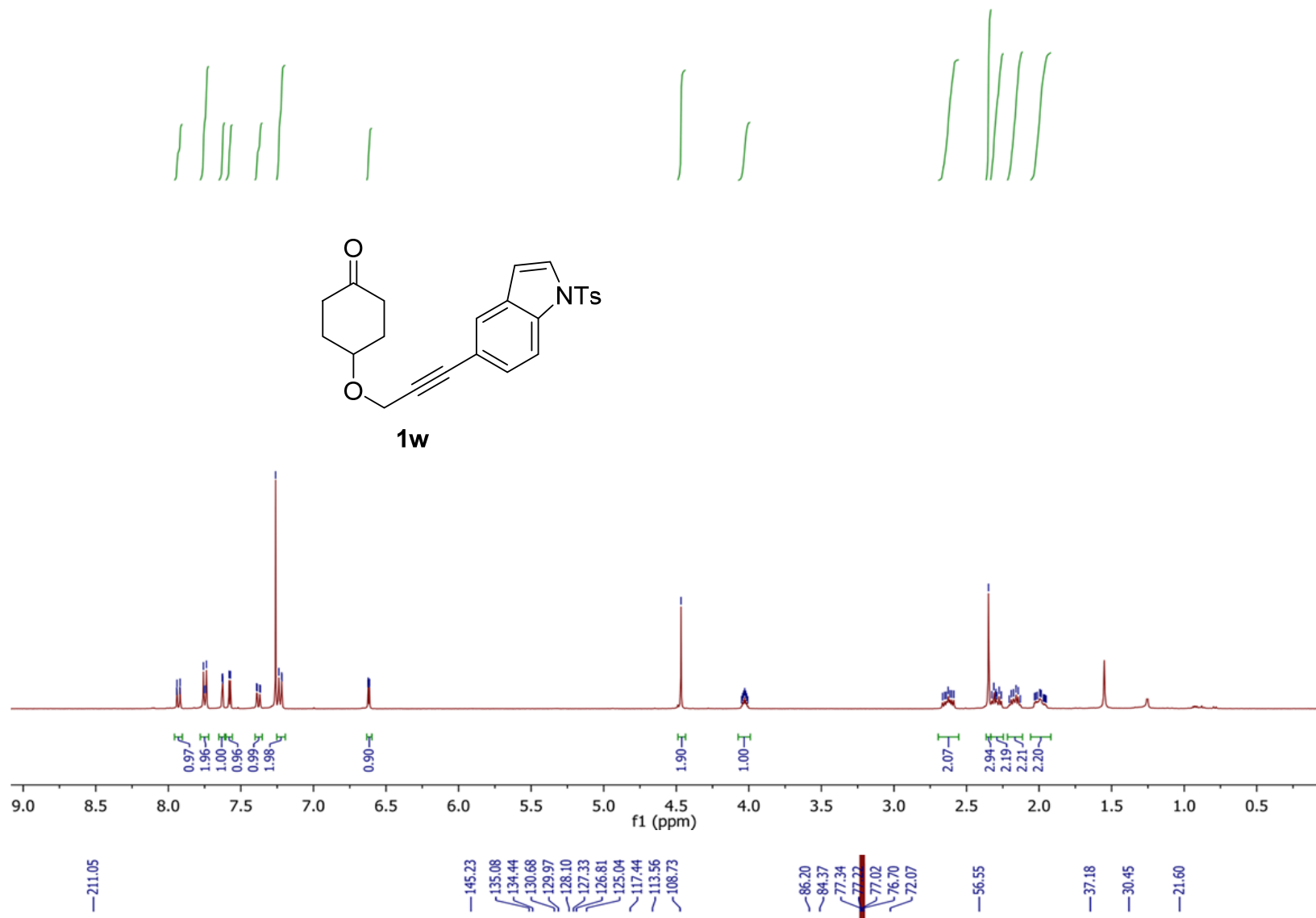

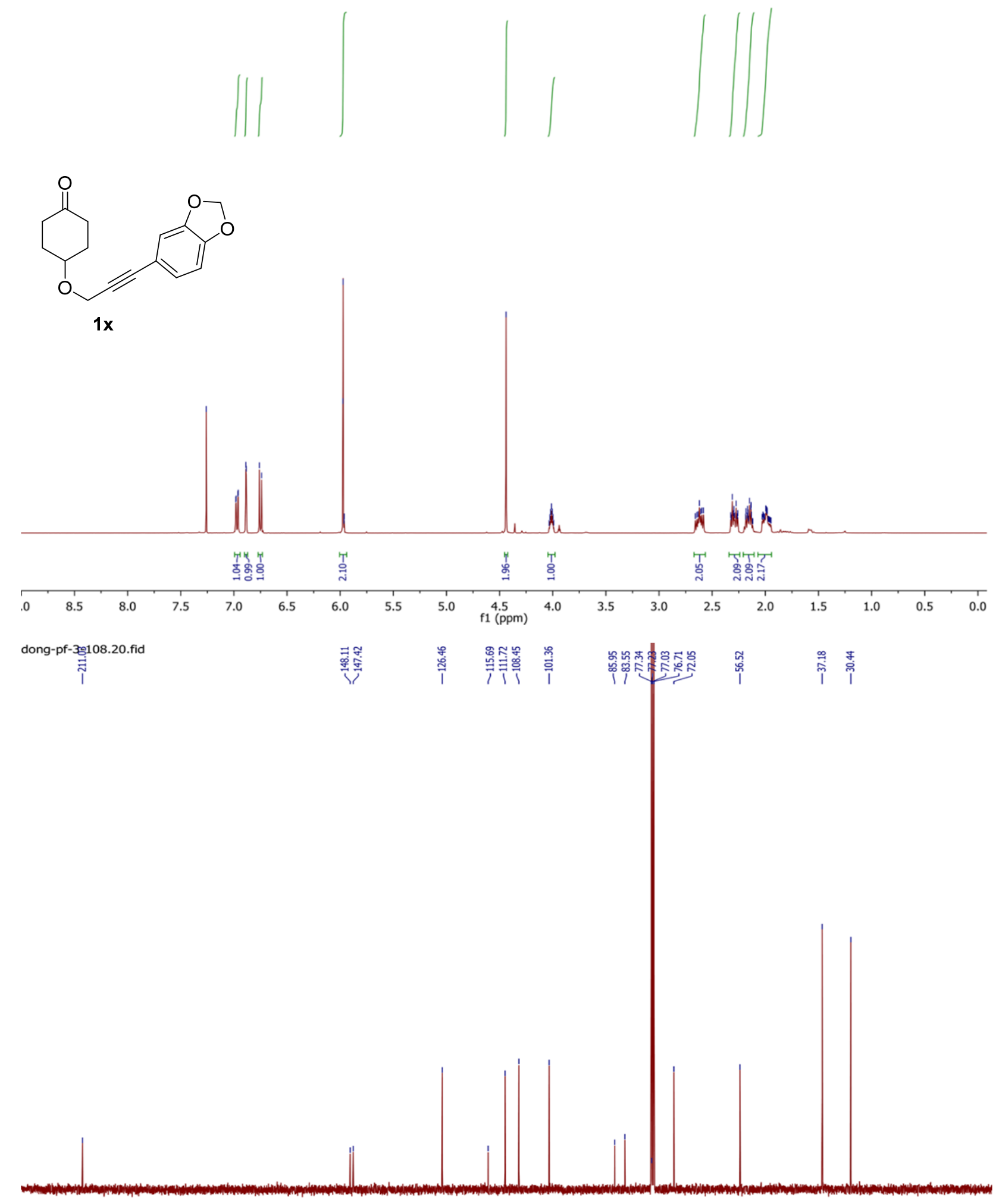

$1 \mathrm{x}$
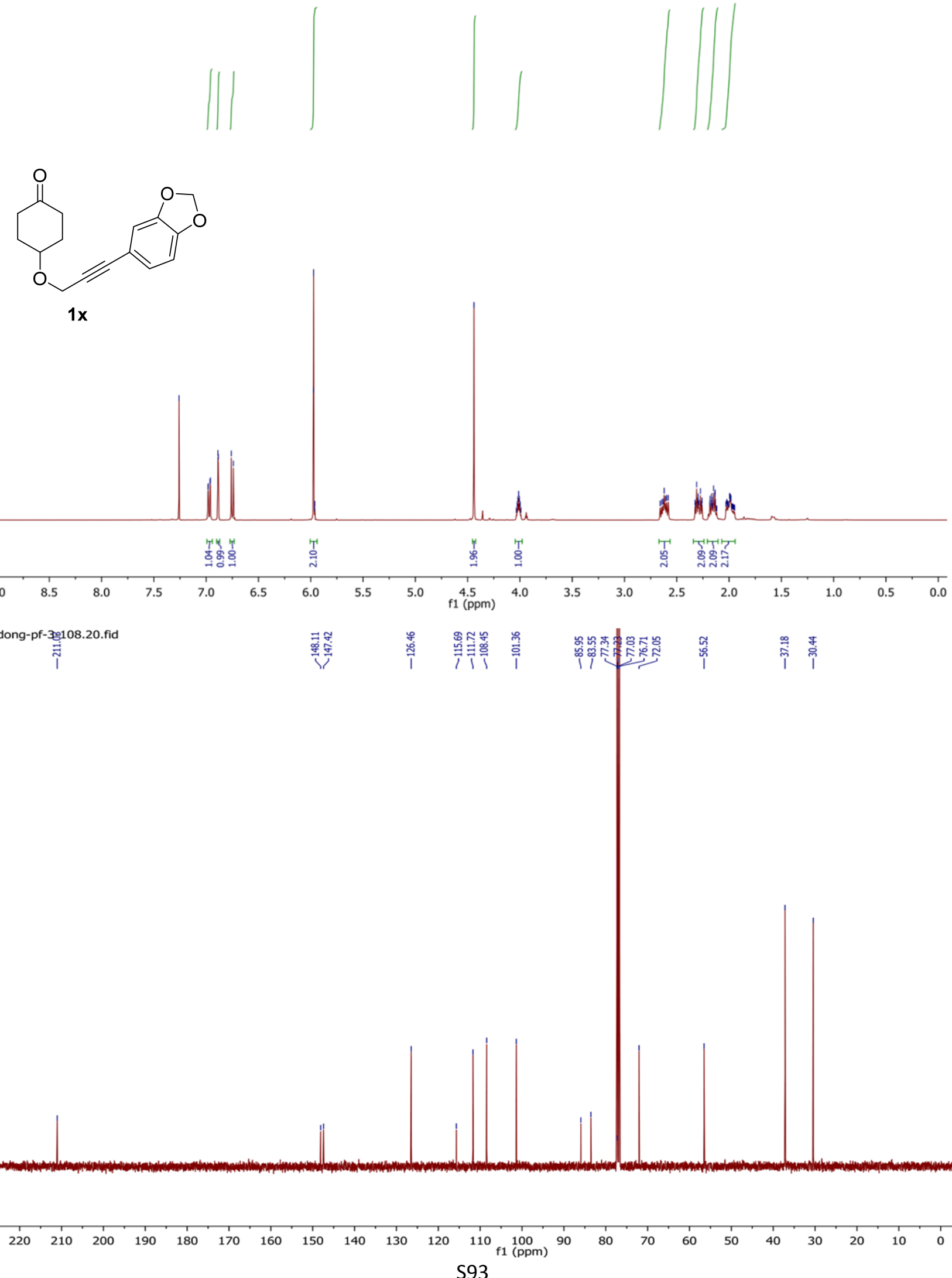


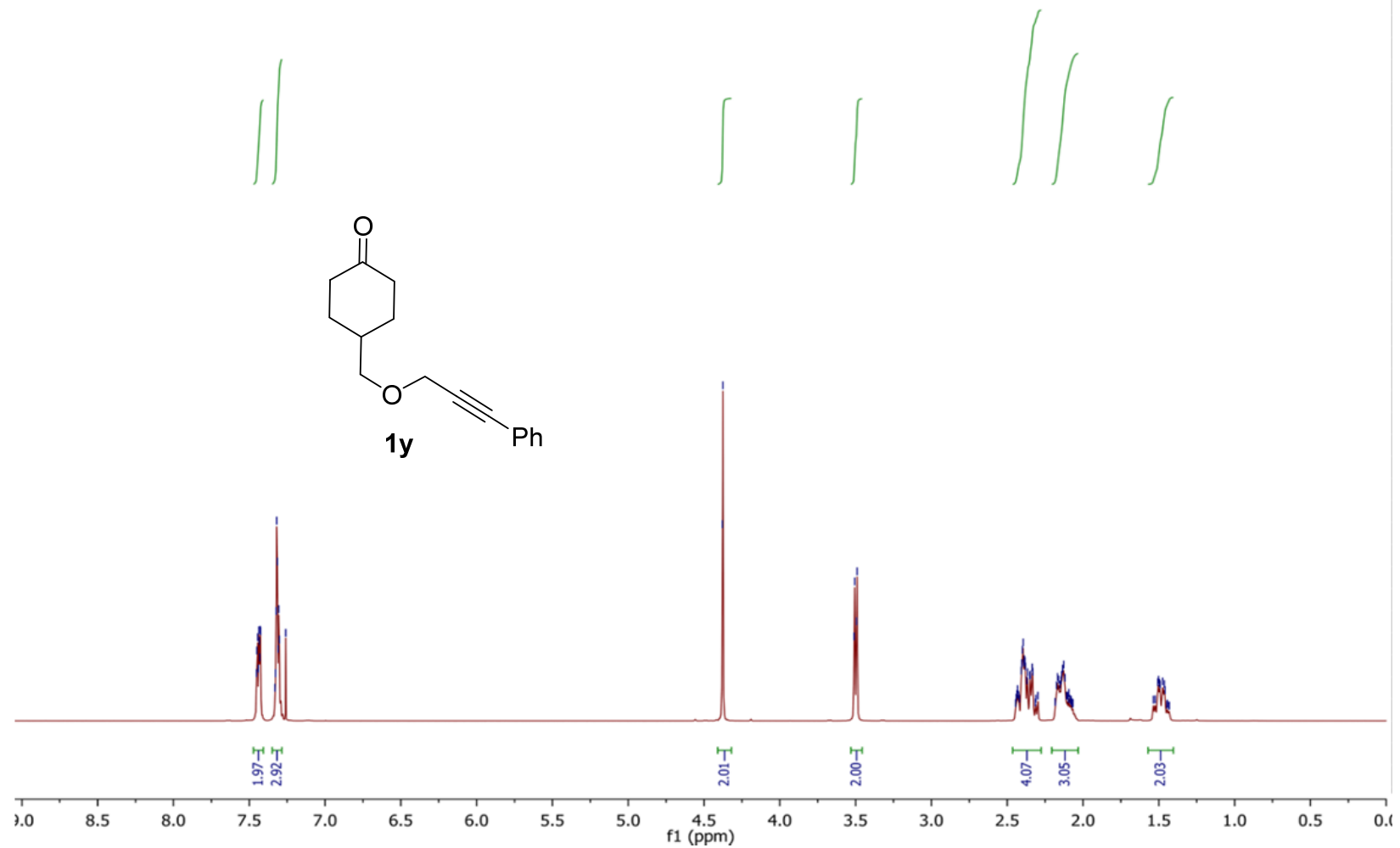

dong-pf-sm-mo-I.10.fid

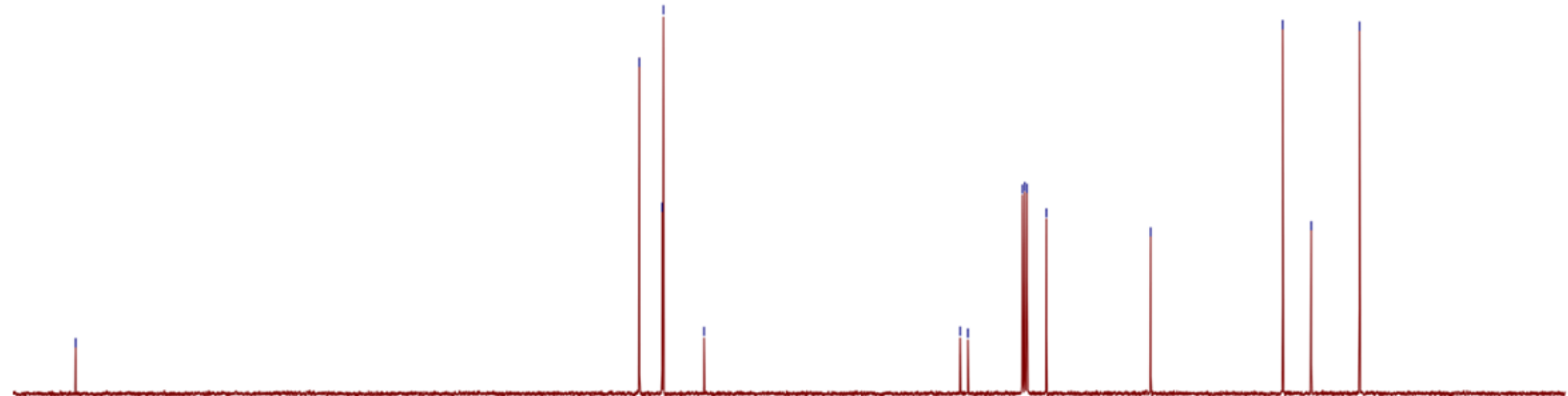

$\begin{array}{lllllllllllllllllllllllll}20 & 210 & 200 & 190 & 180 & 170 & 160 & 150 & 140 & 130 & 120 & \begin{array}{l}110 \\ \mathrm{f} 1(\mathrm{ppm})\end{array} & 100 & 90 & 80 & 70 & 60 & 50 & 40 & 30 & 20 & 10 & \end{array}$ 


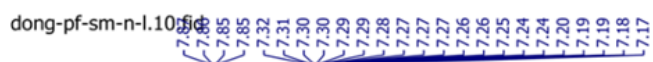

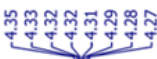

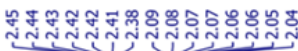
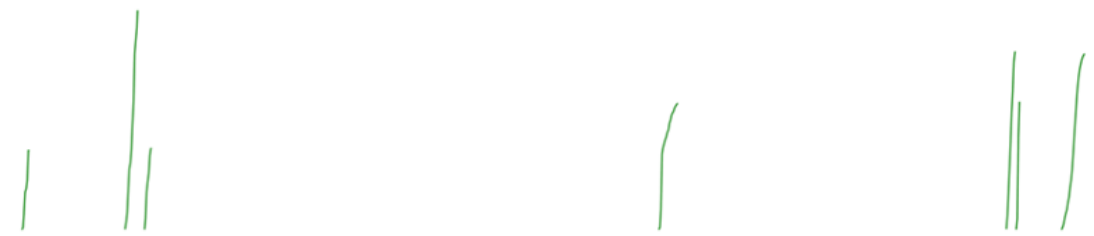

(96\% purity)
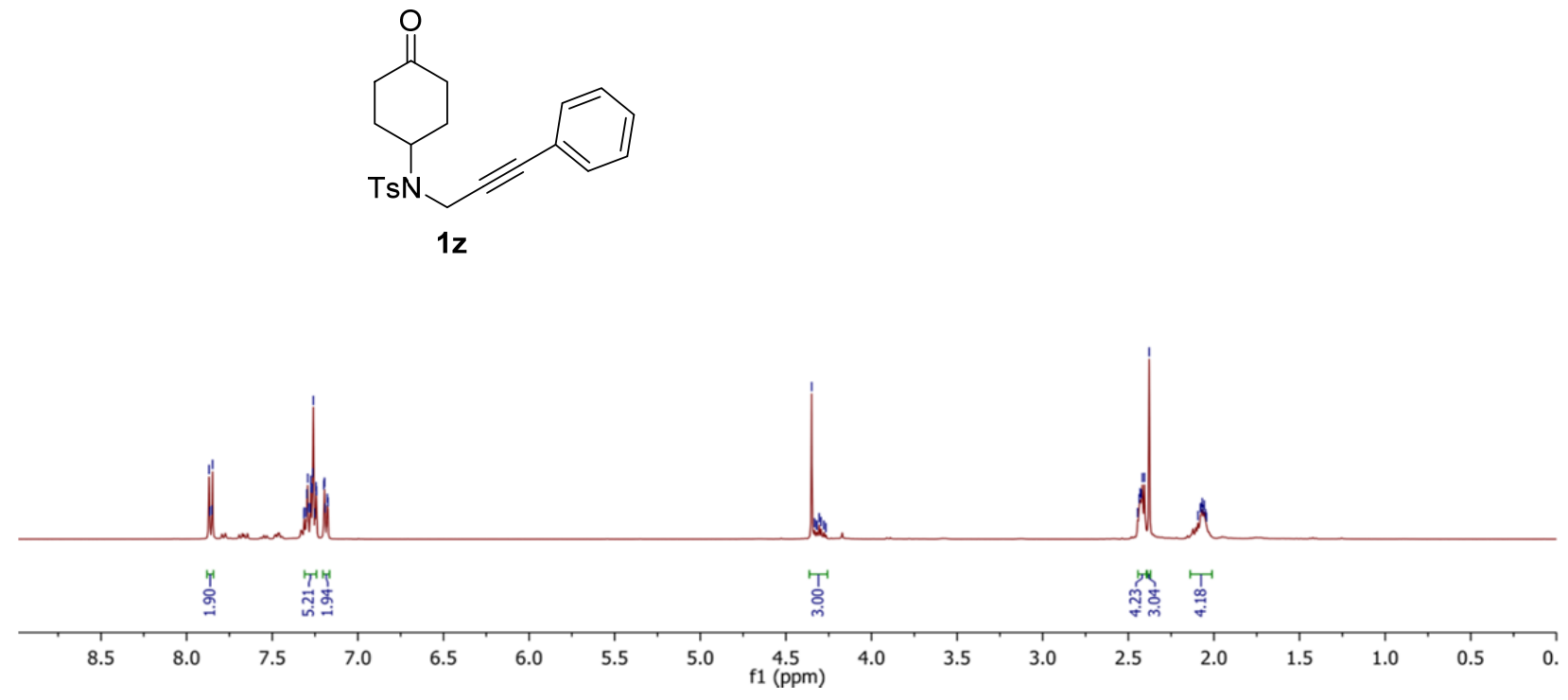

dong-pf gुgm-n-l.11.fid

i

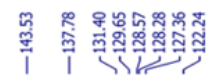

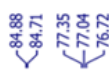

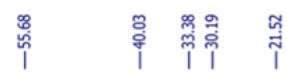
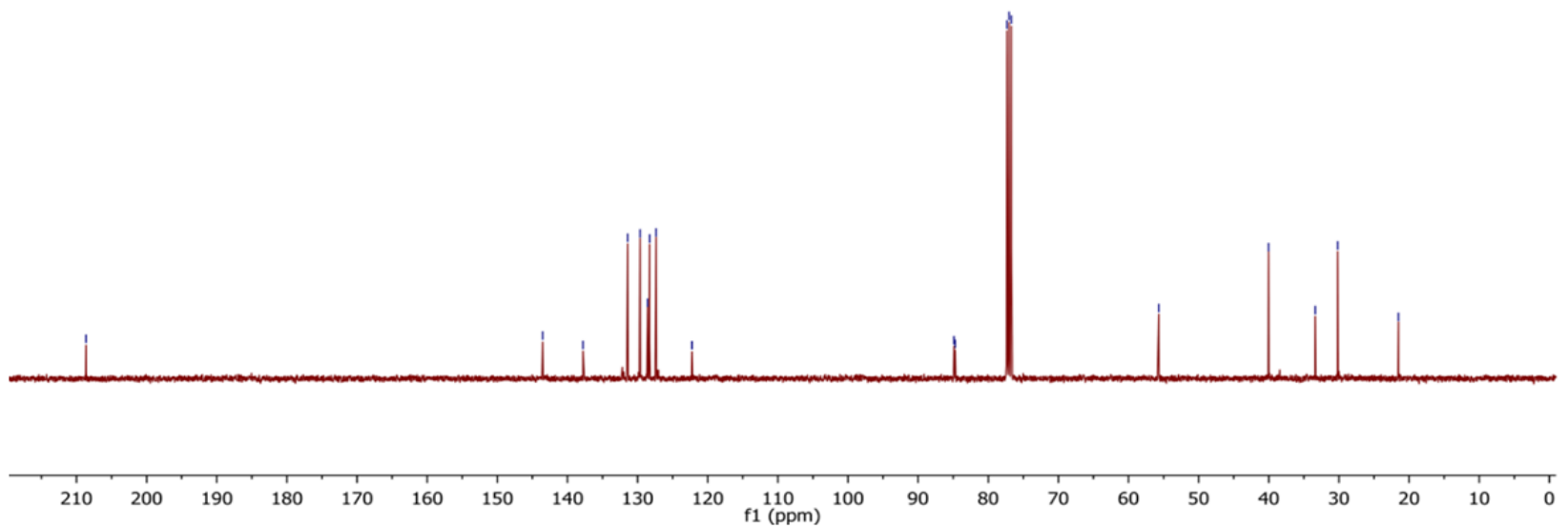


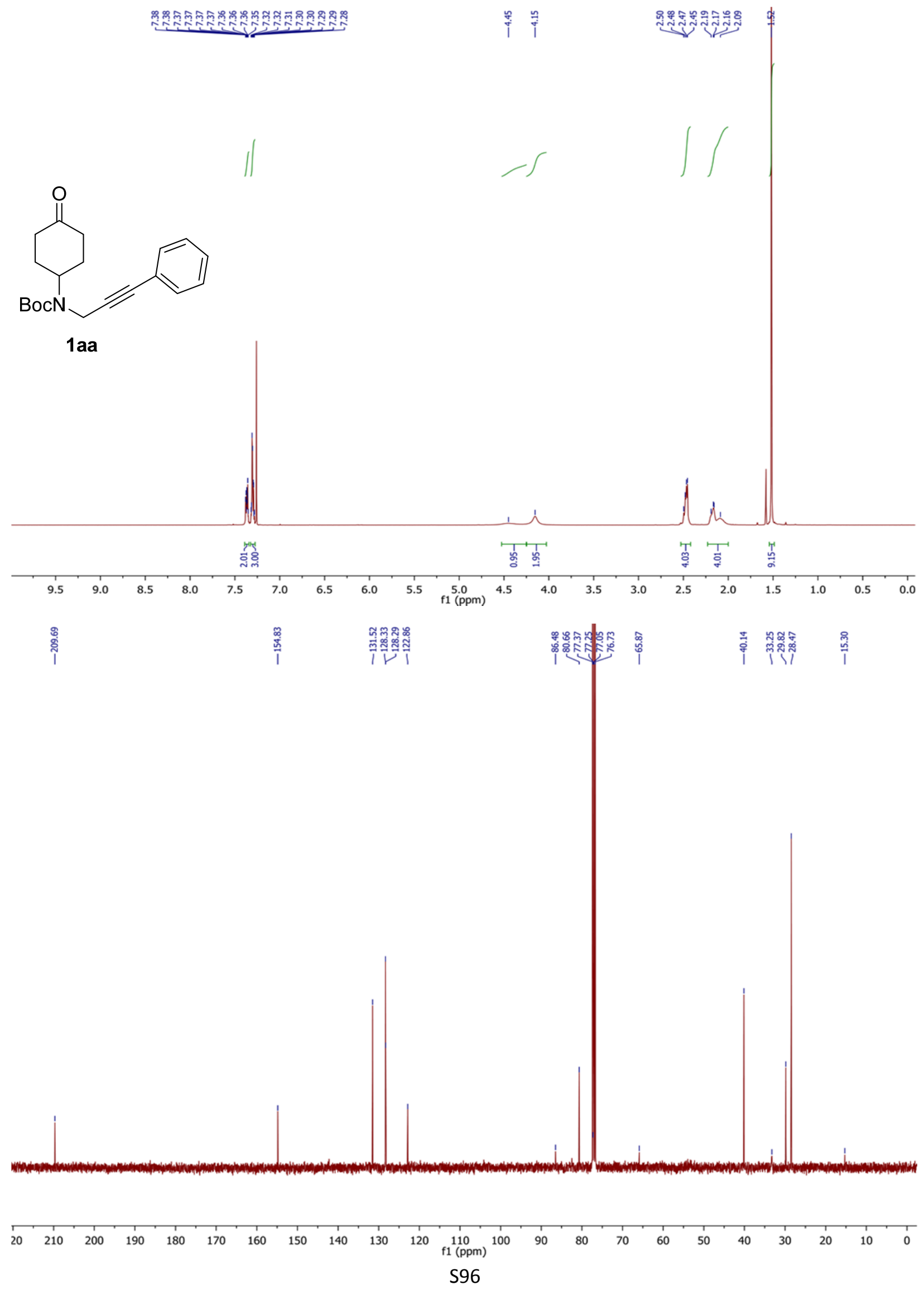



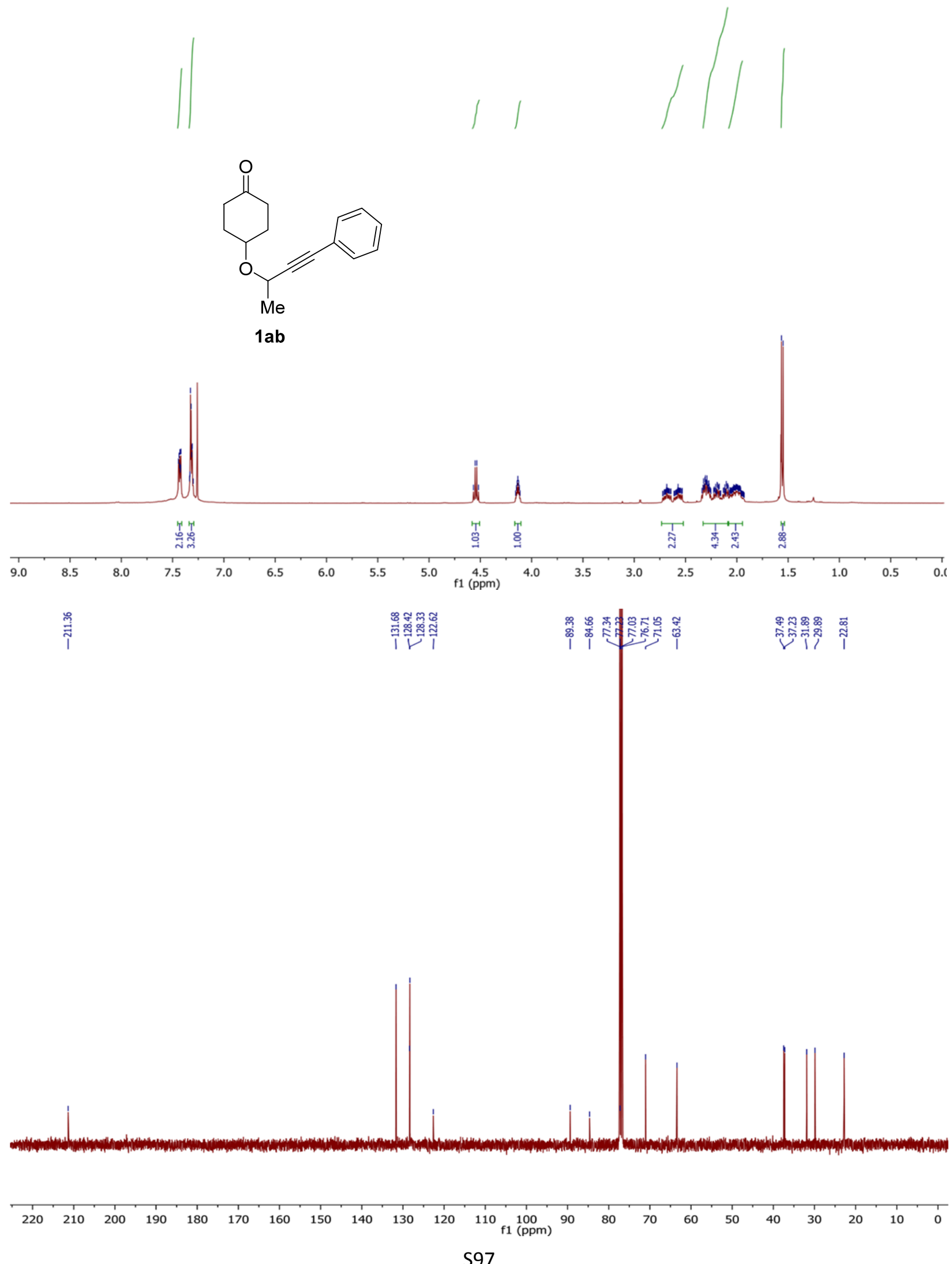

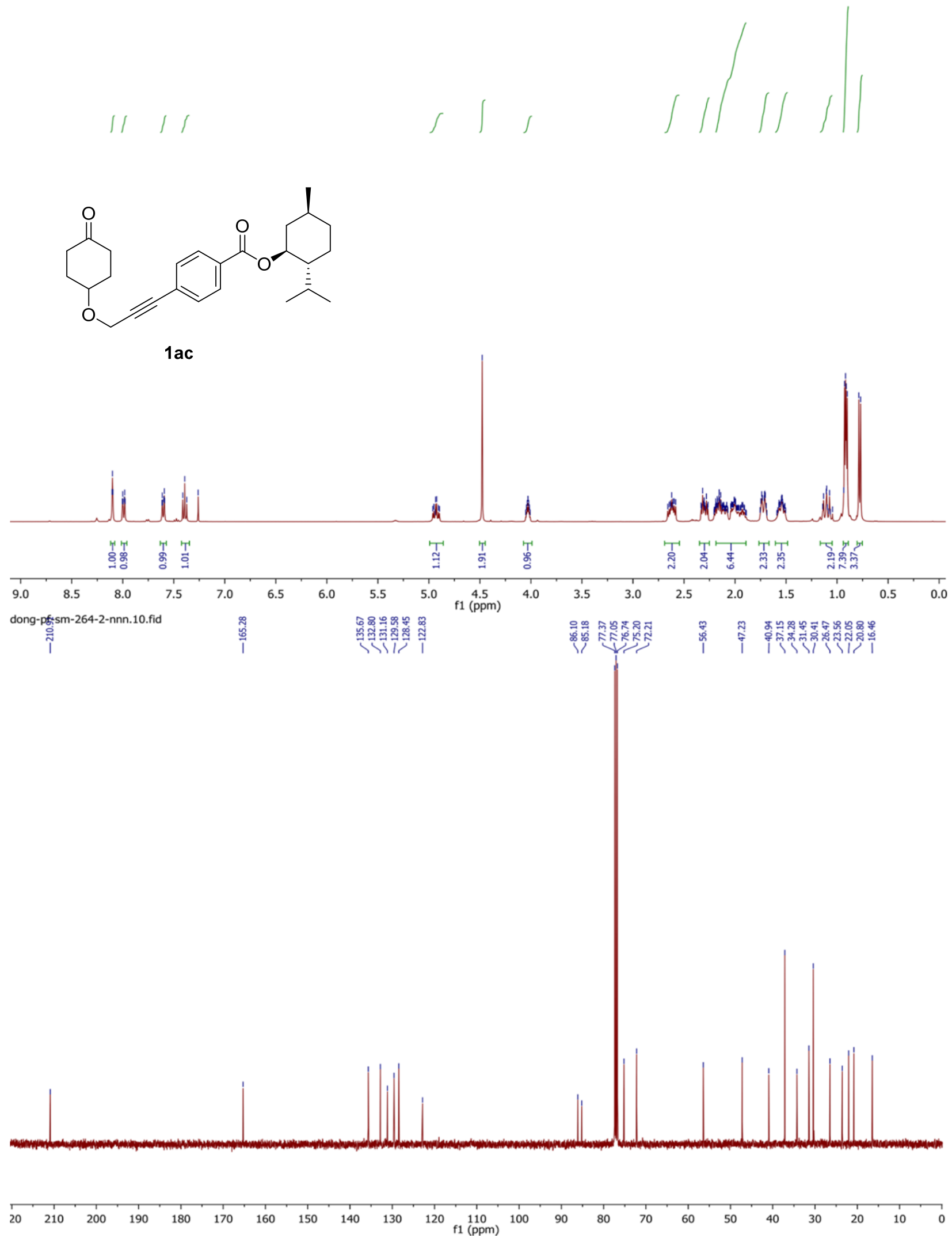

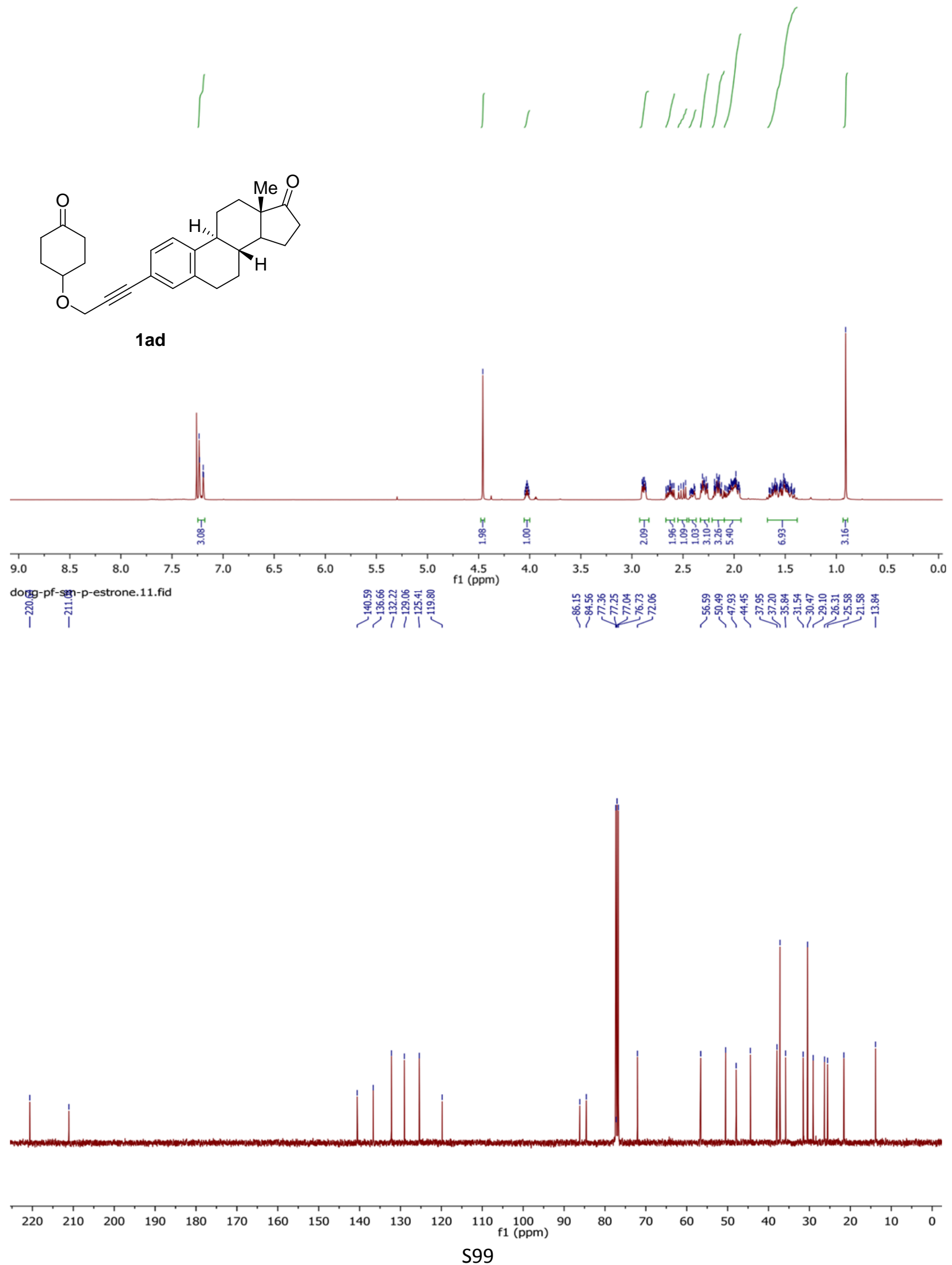


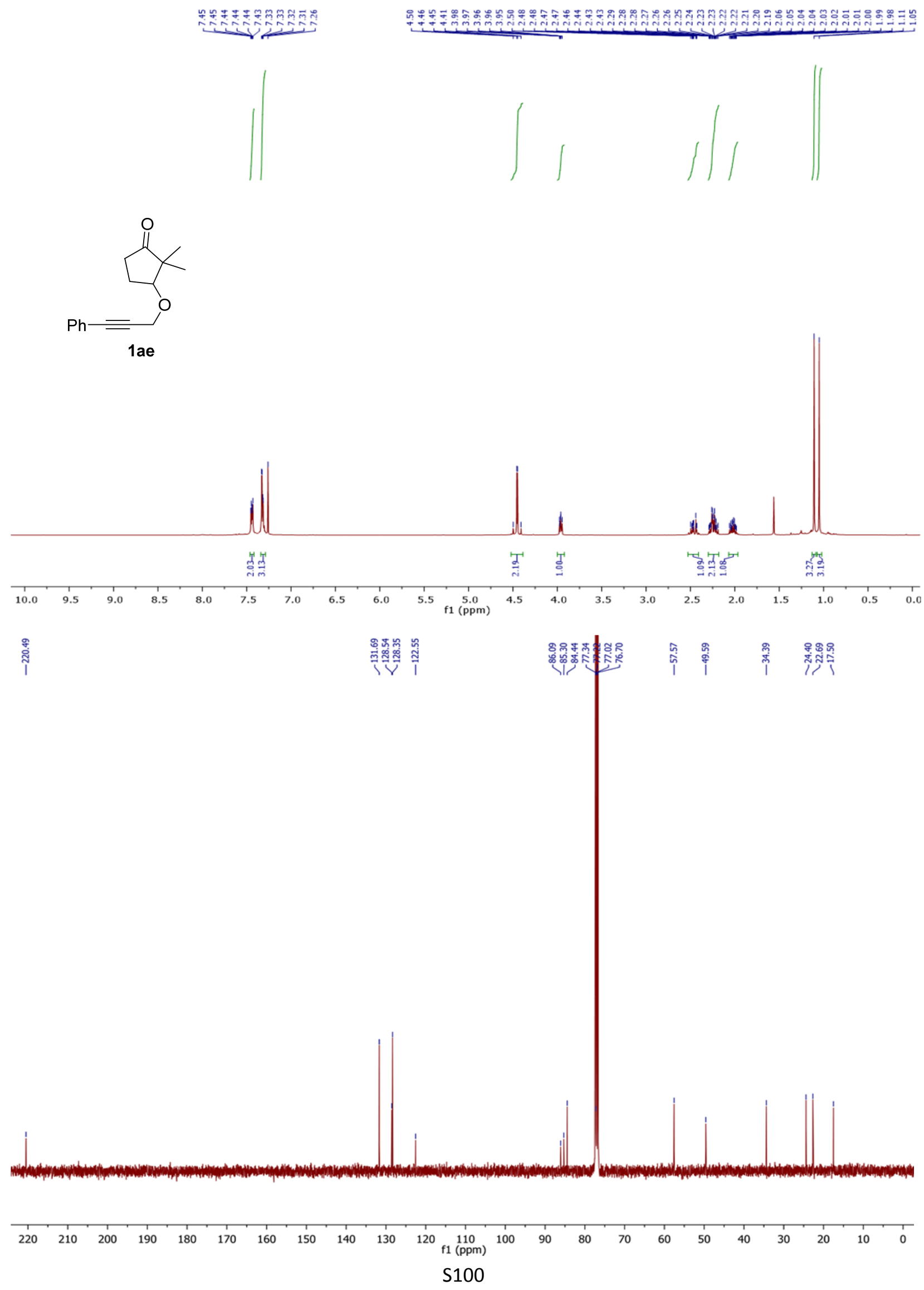




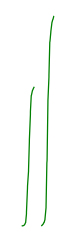<smiles>O=C1CCCC(OCC#CPc2ccccc2)C1</smiles>

1 af
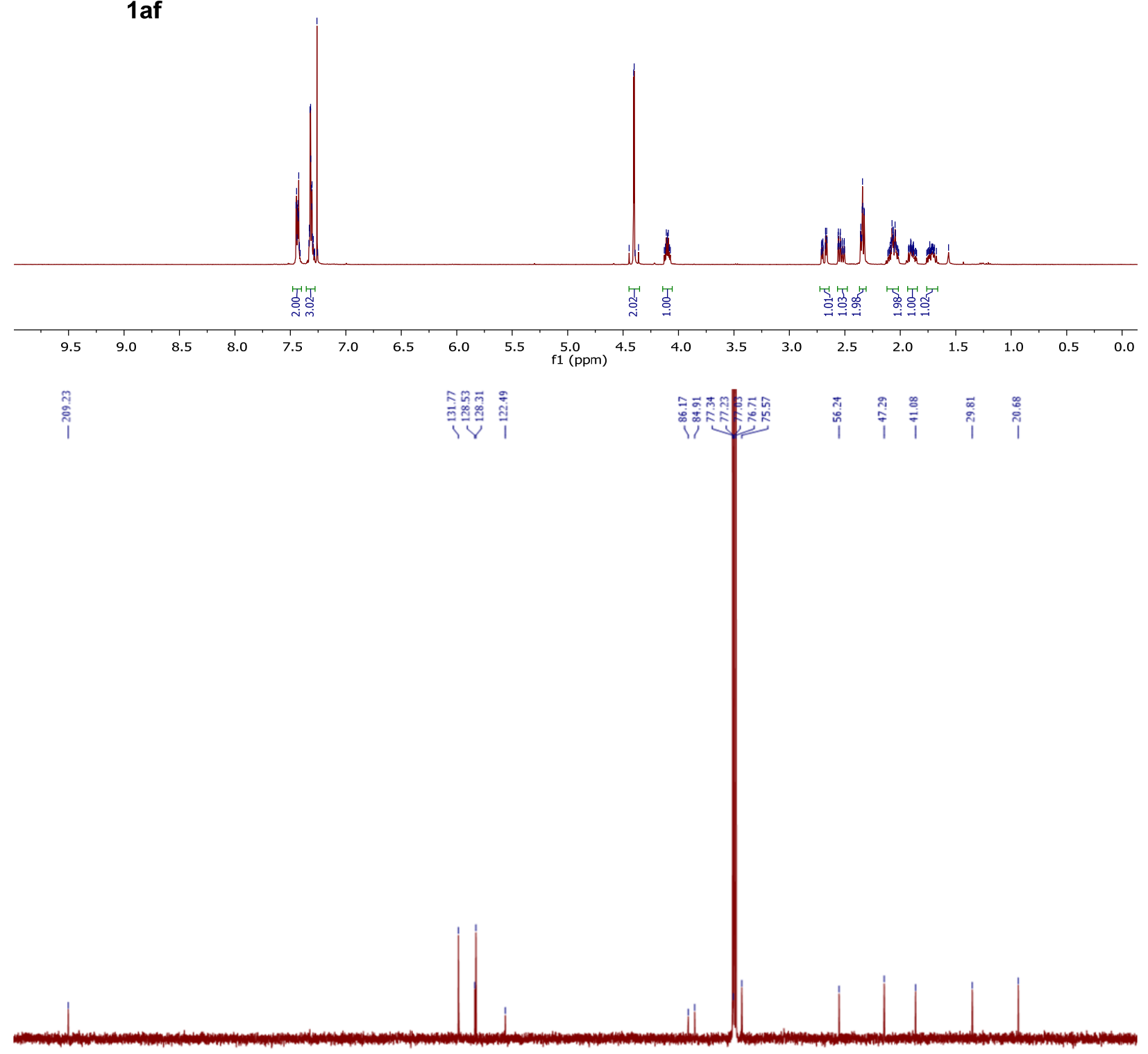

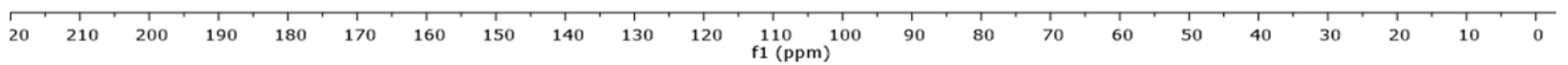


<smiles>O=C1CCC(OCCC#Cc2ccccc2)CC1</smiles>

1 ag
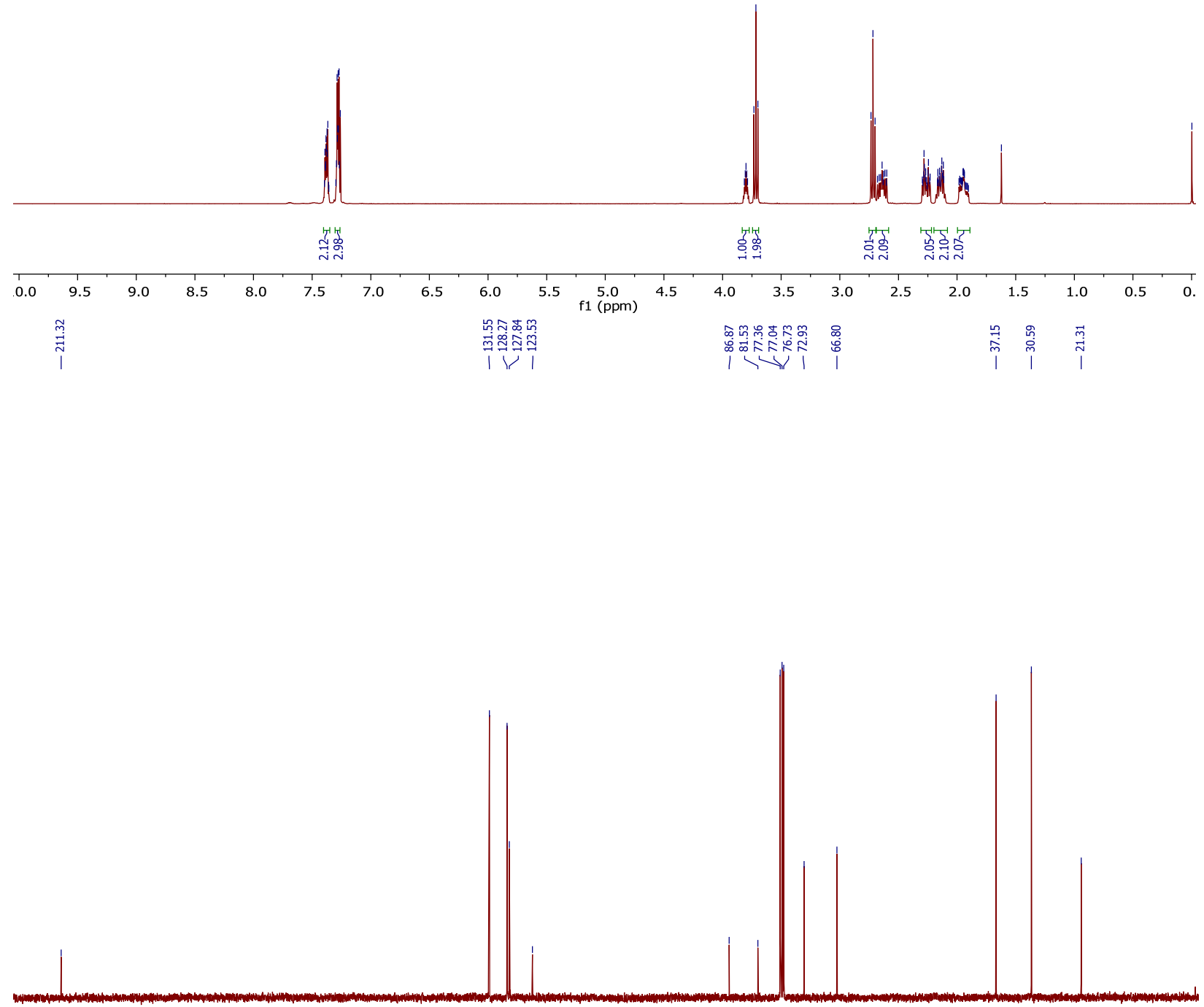

\begin{tabular}{llllllllllllllllllllll}
\hline & 210 & 200 & 190 & 180 & 170 & 160 & 150 & 140 & 130 & 120 & $\underset{\mathrm{f} 1(\mathrm{ppm})}{100}$ & 90 & 80 & 70 & 60 & 50 & 40 & 30 & 20 & 10 & $\mathrm{C}$
\end{tabular} S102 

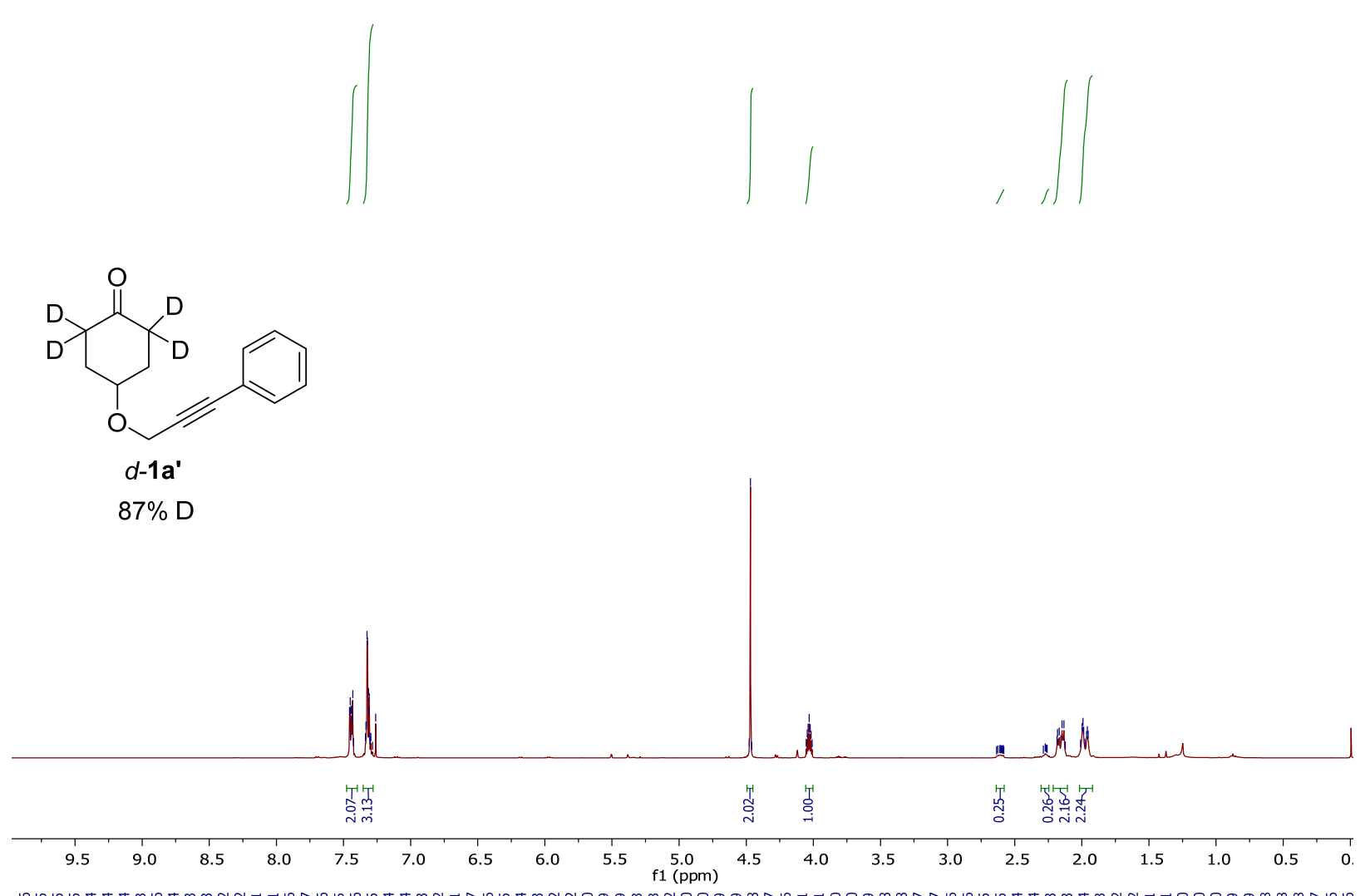

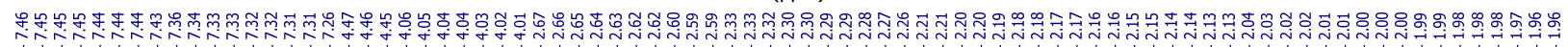
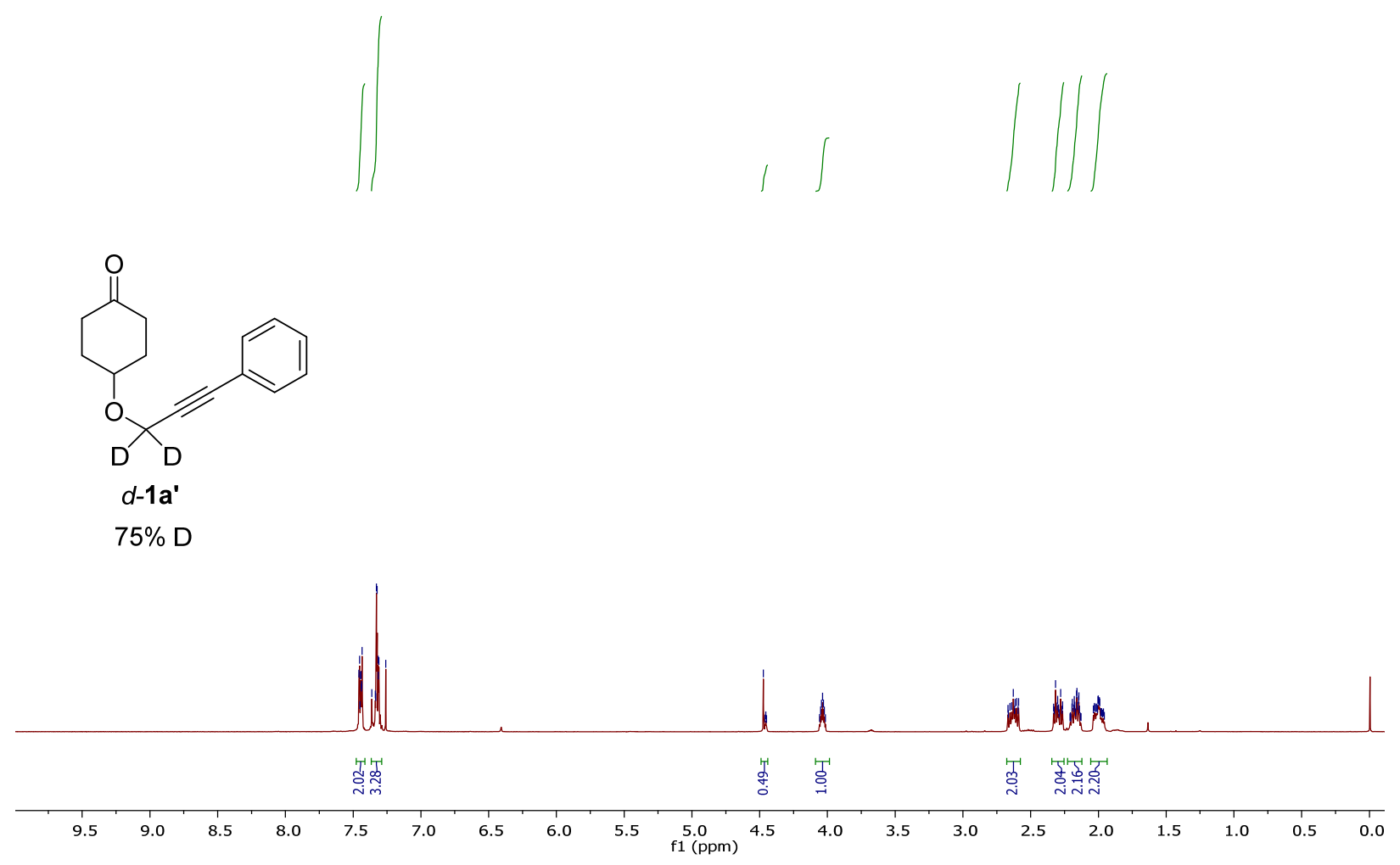
<smiles>O=C1CCC2CC1OC2/C=C/Pc1ccccc1</smiles>

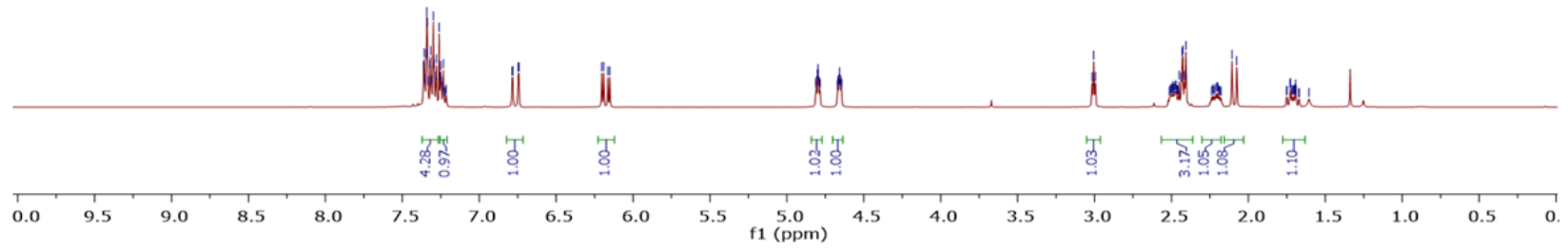

商

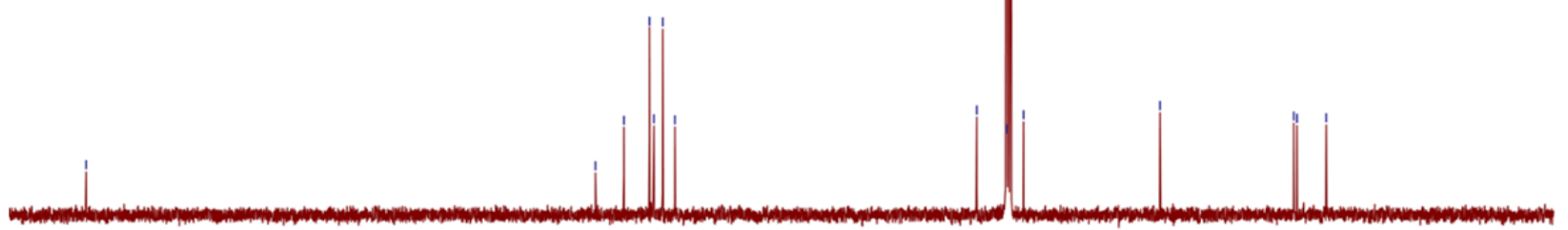

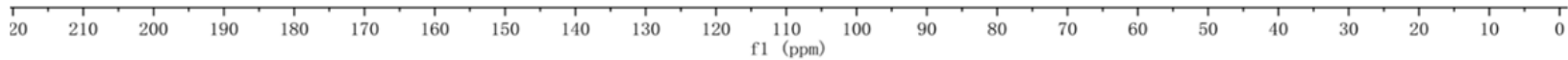



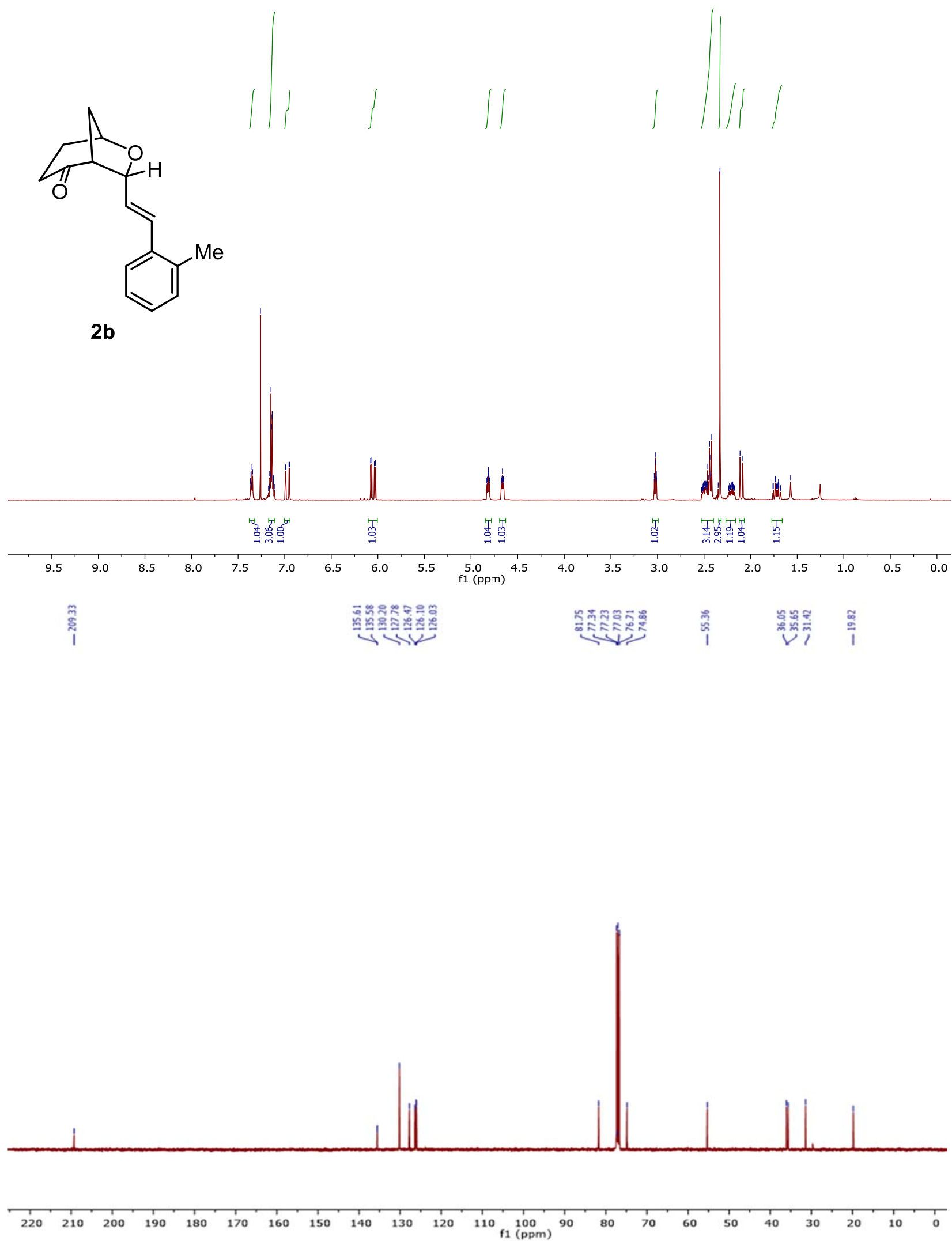


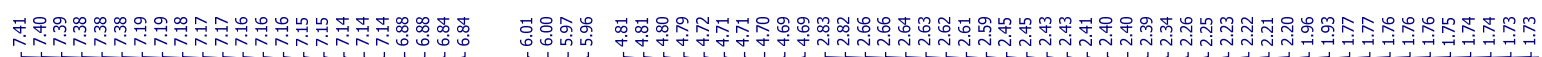

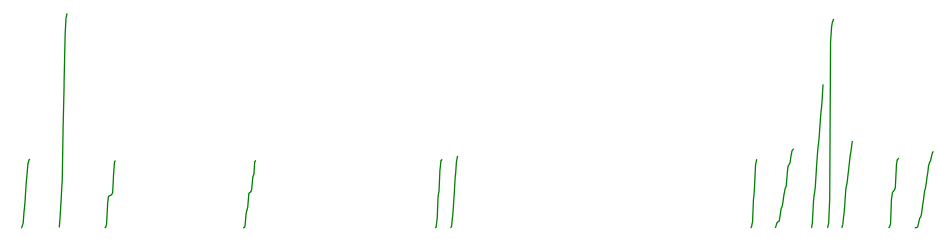<smiles>Cc1ccccc1/C=C/C1OC2CCC(OC2)C1CO</smiles>

2b"

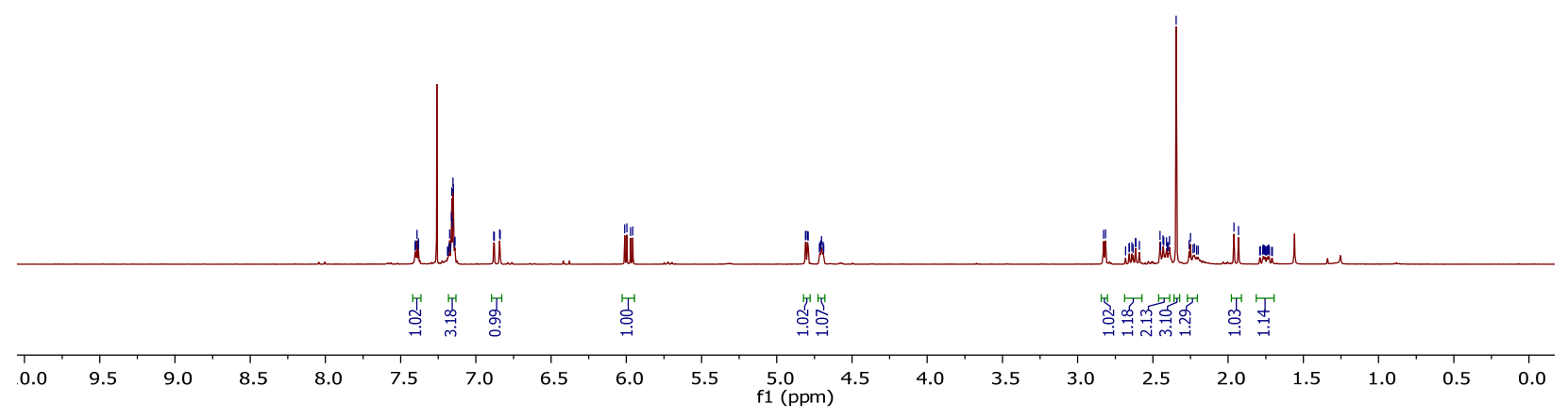

竞

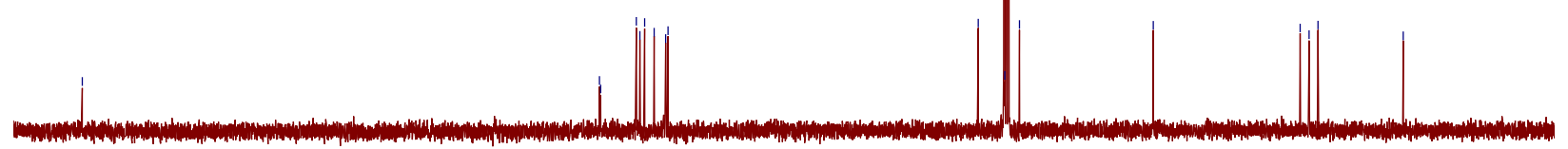

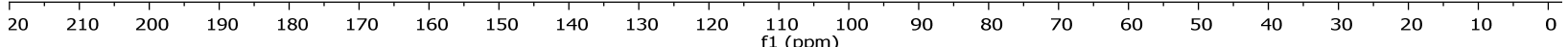
S106 


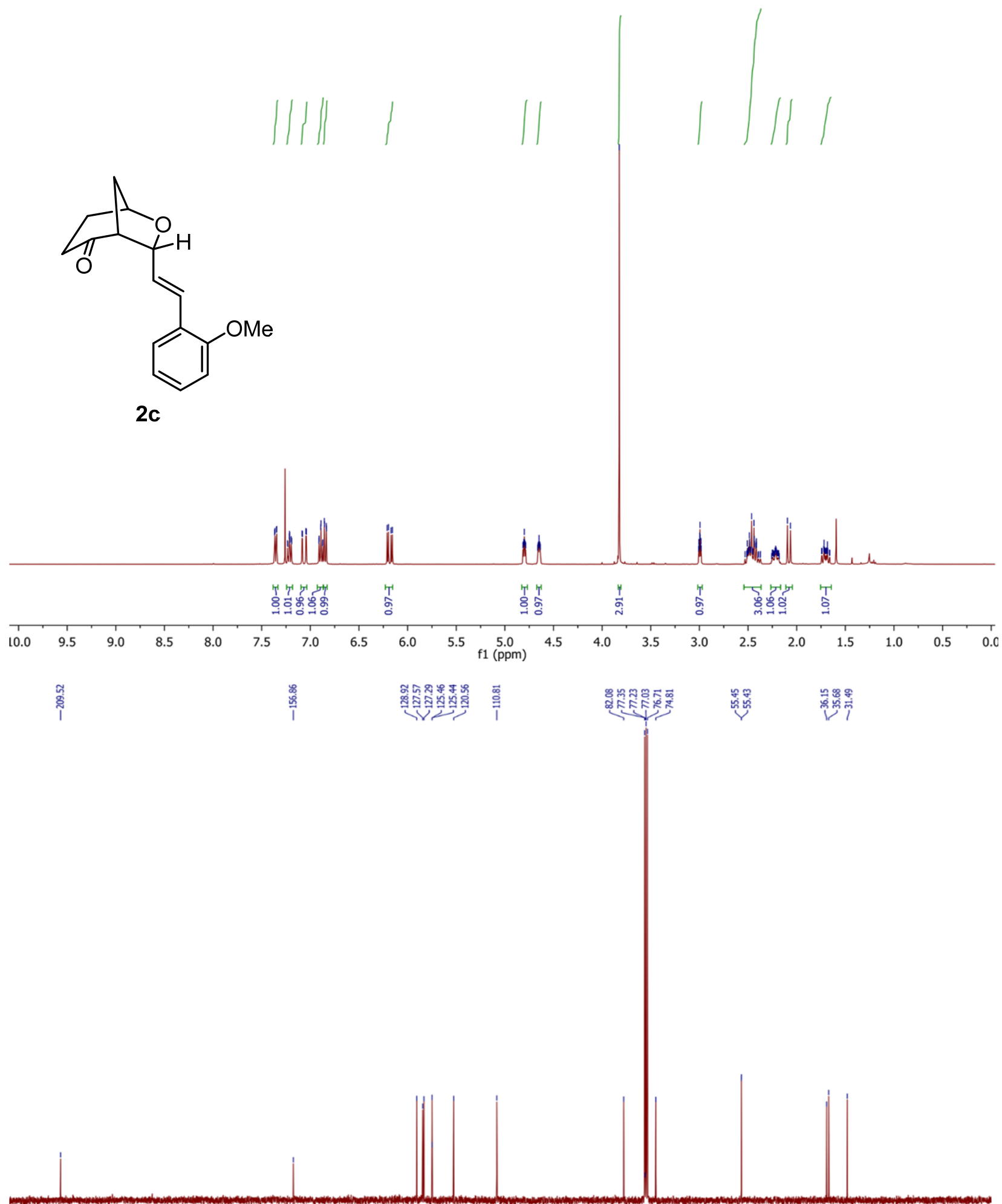

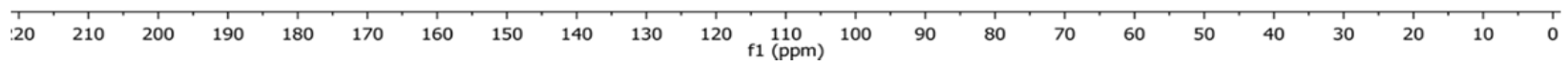


<smiles>Cc1cccc(/C=C/C2CC3CCC(O)C2C3)c1</smiles>
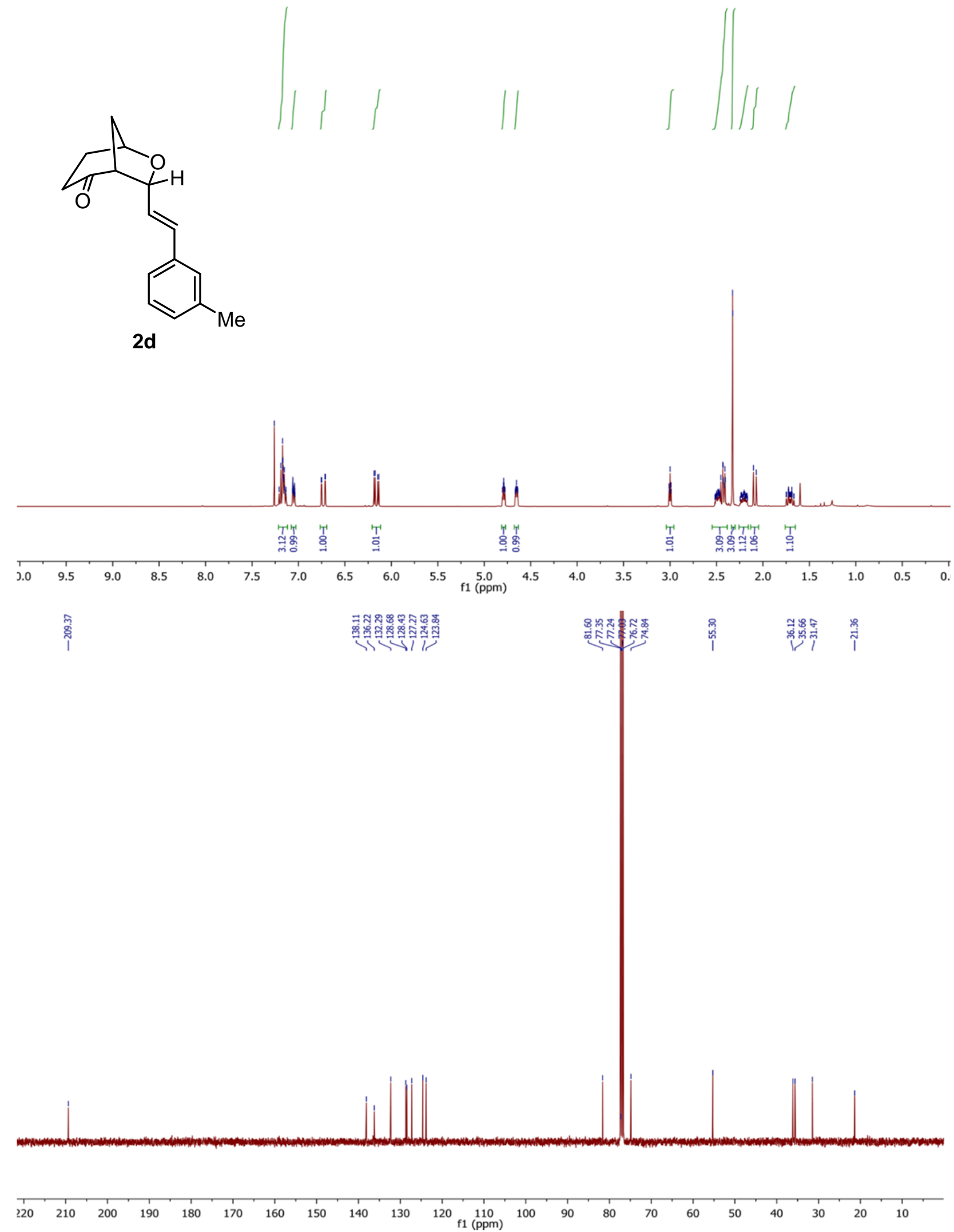
S108 

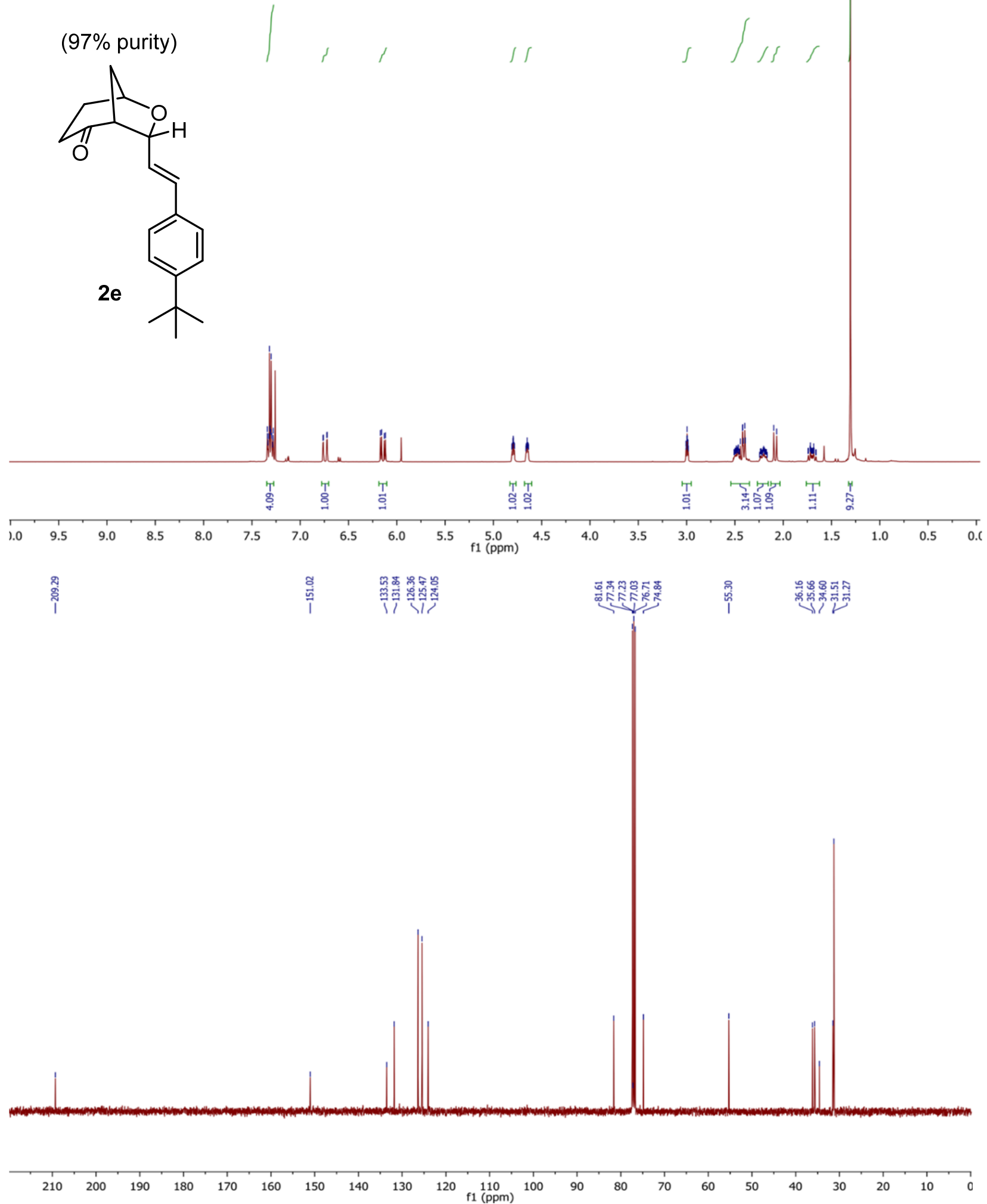

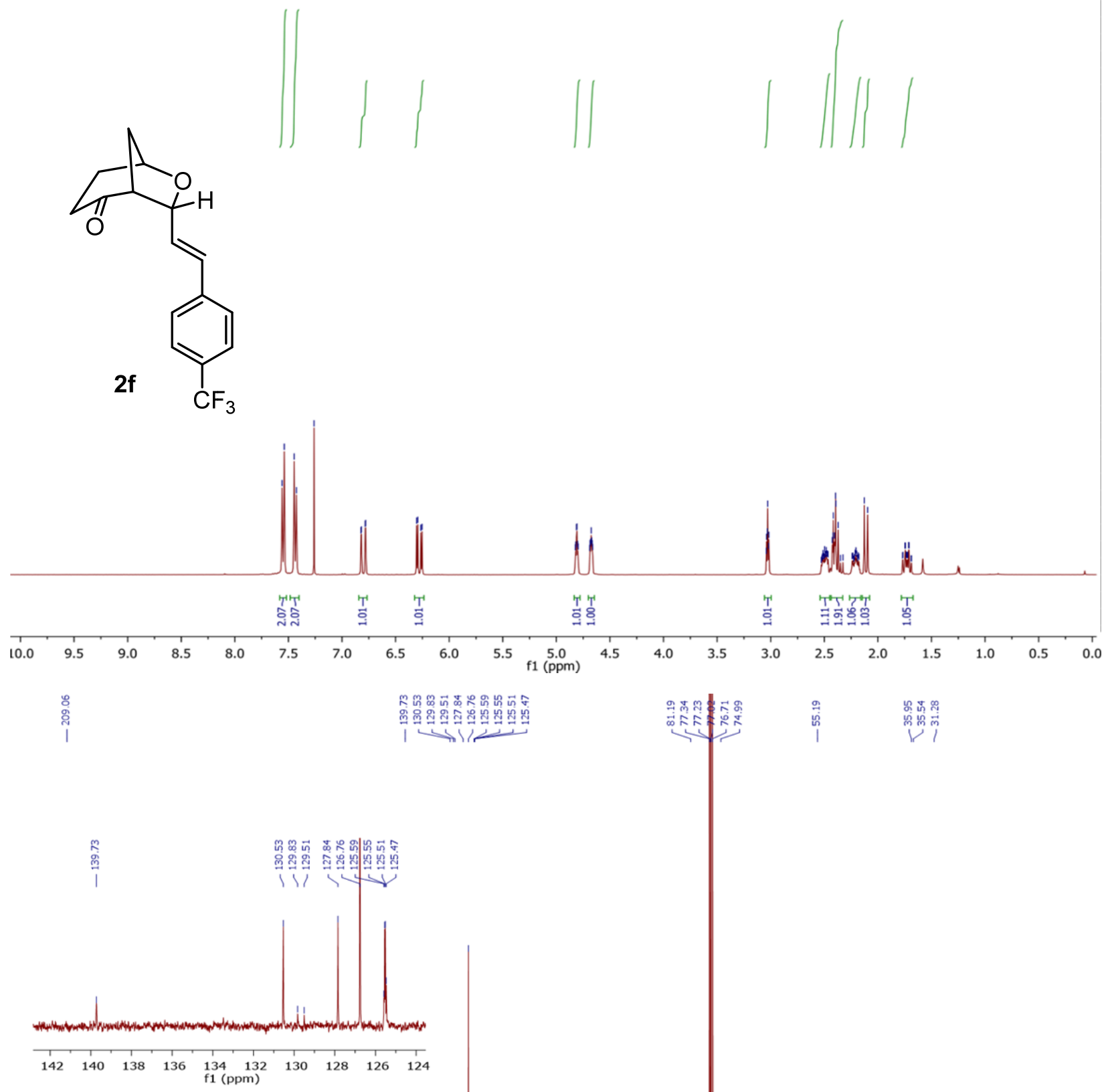

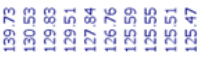

.
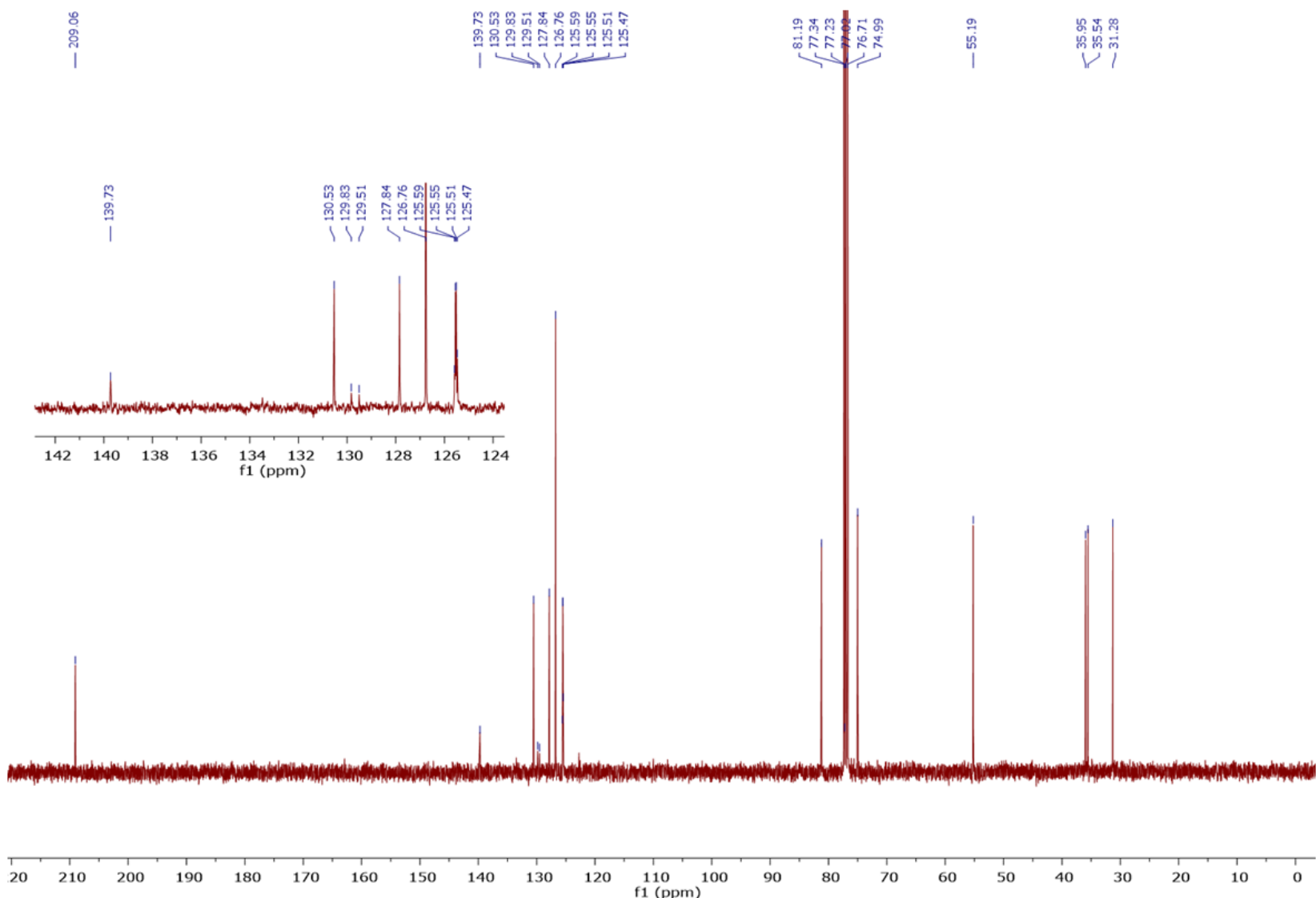

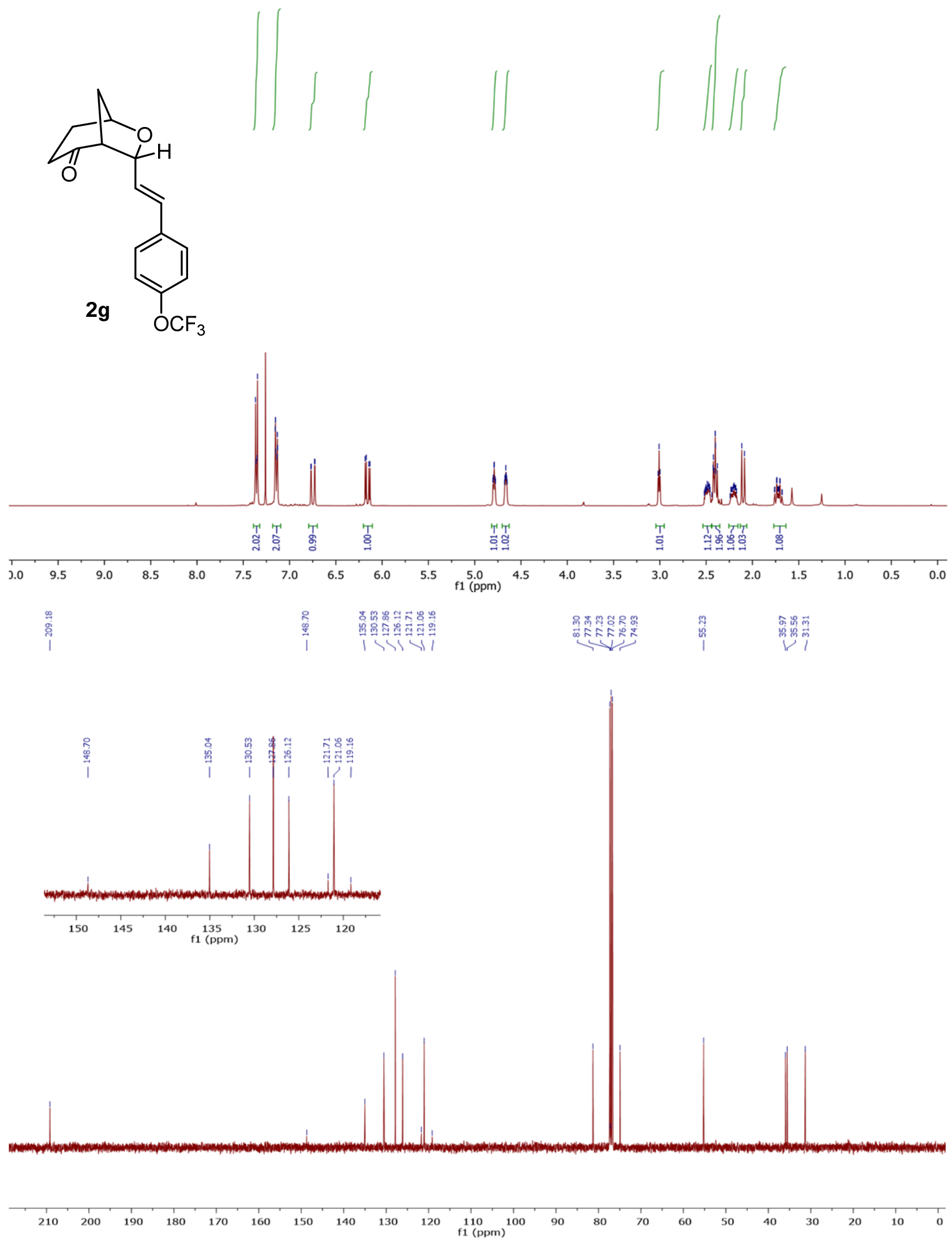

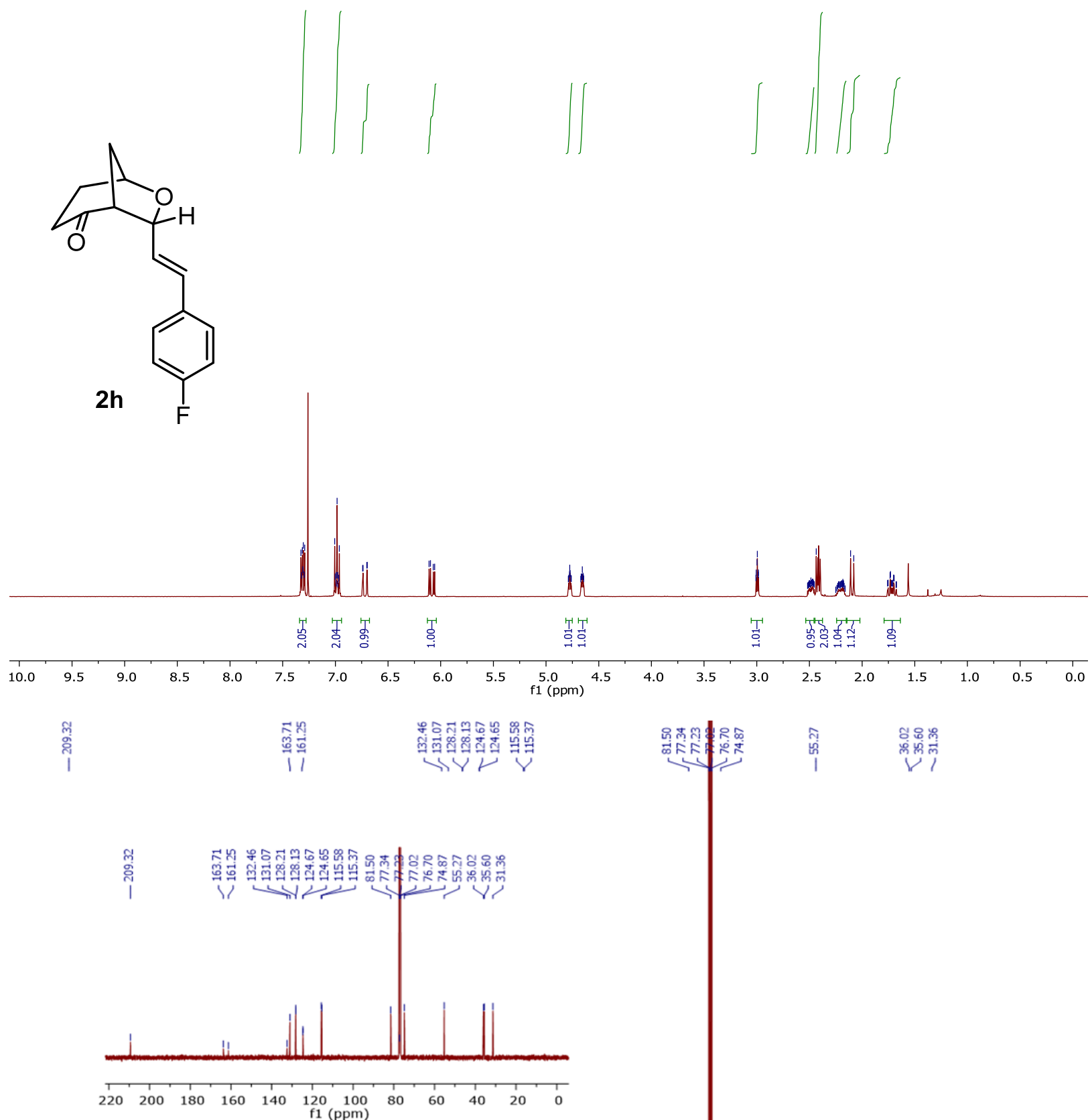

$\mid$

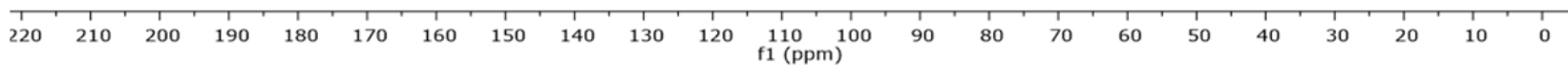



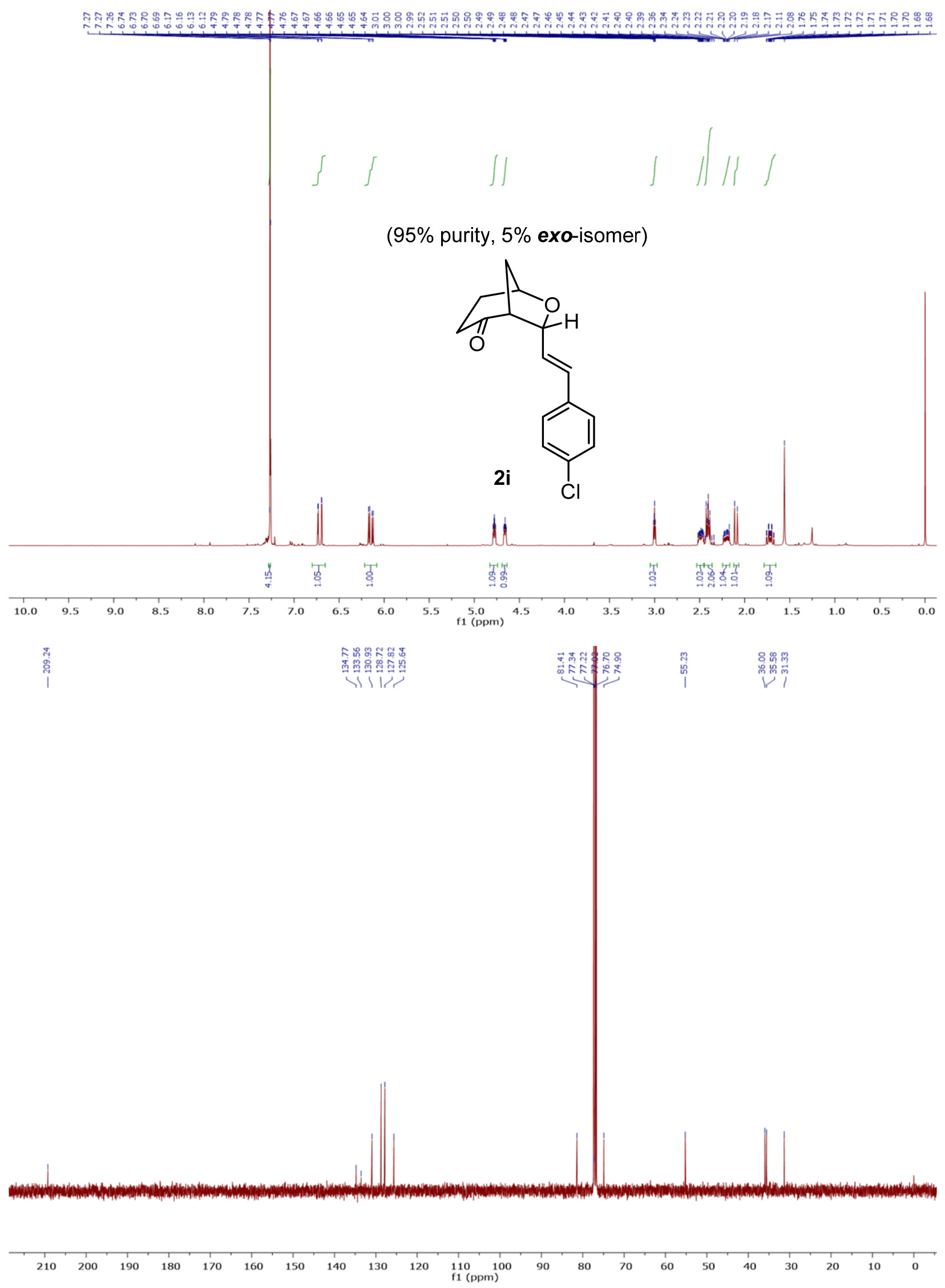

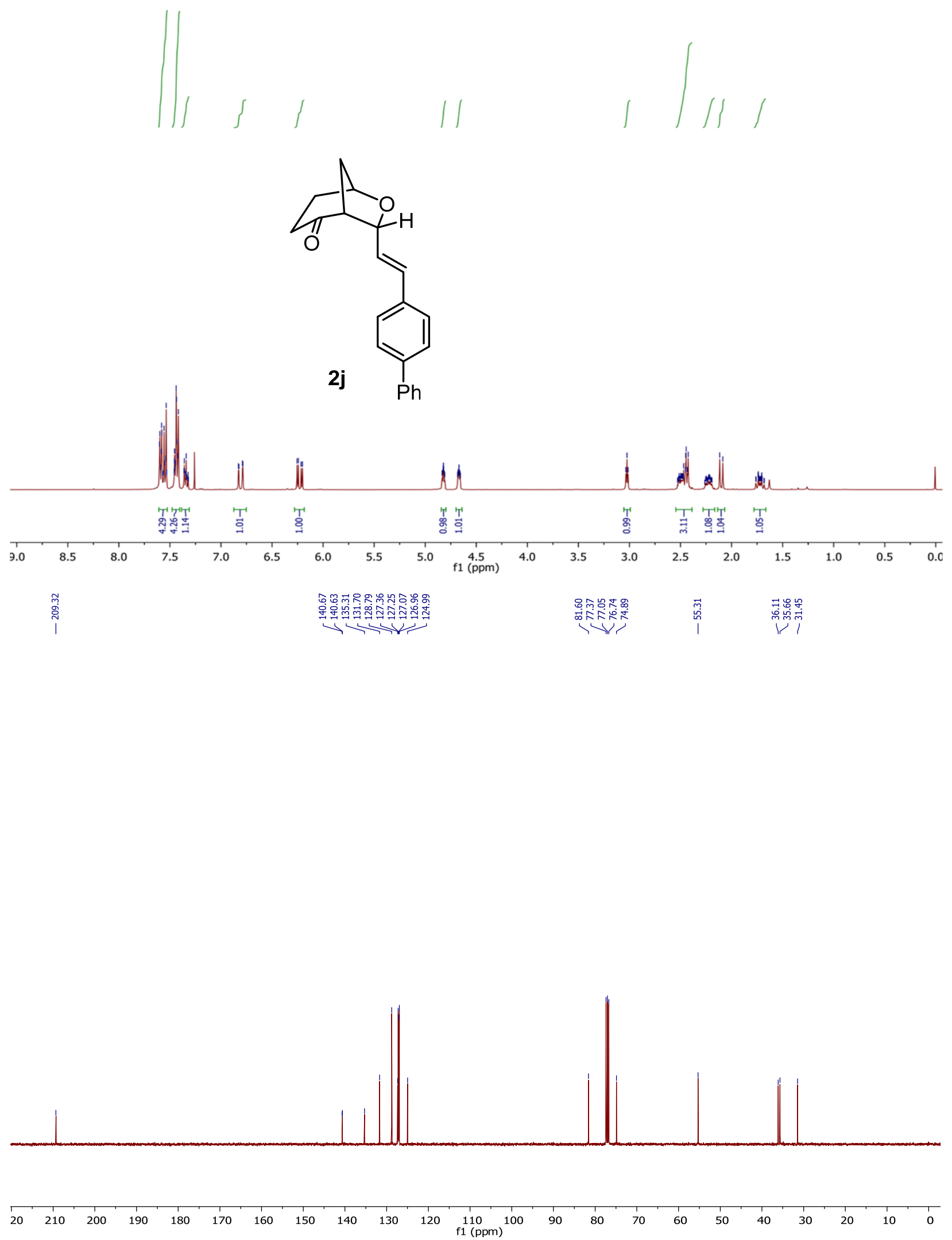


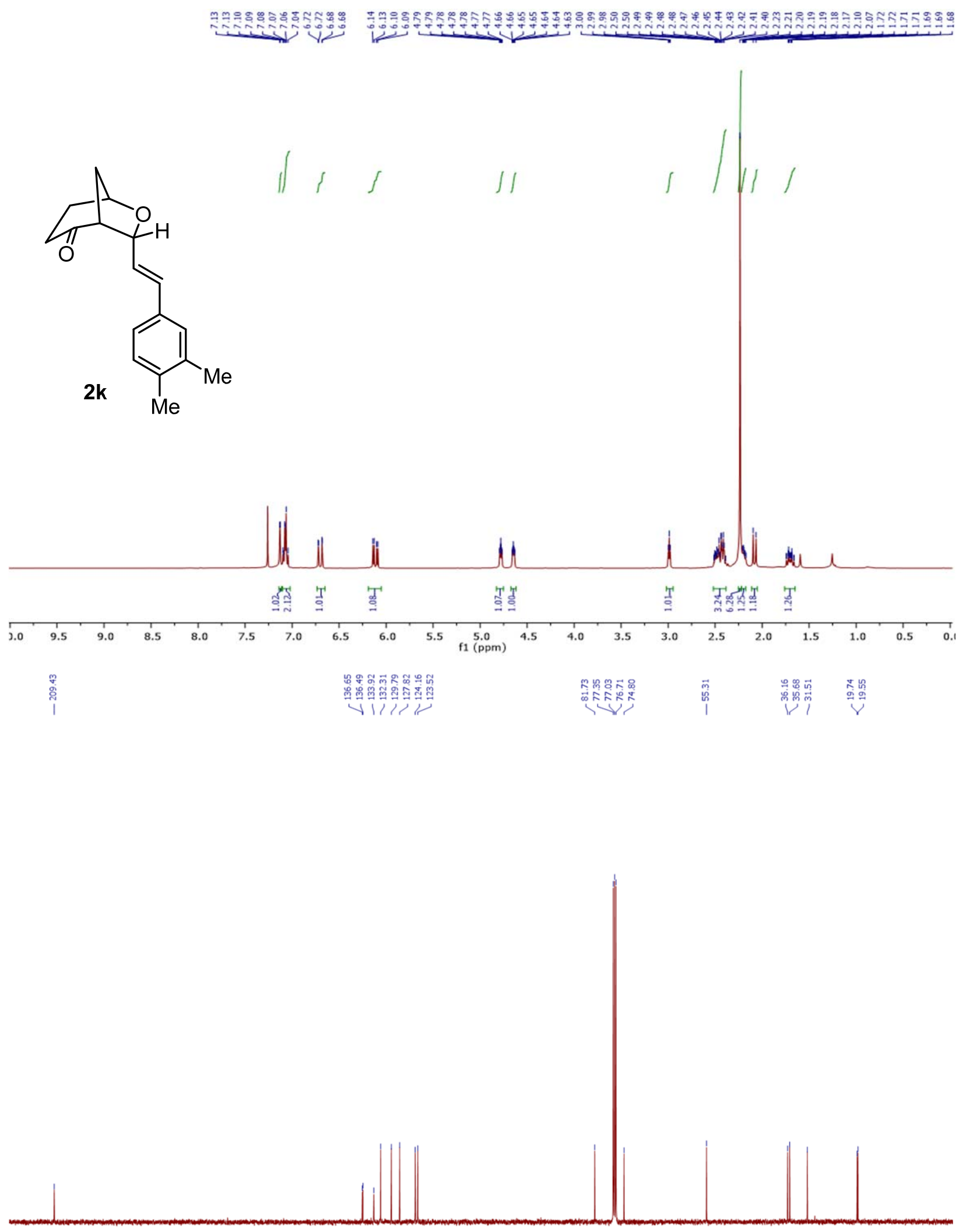

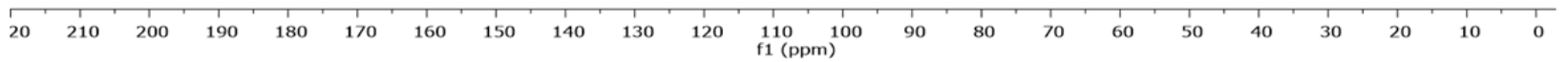



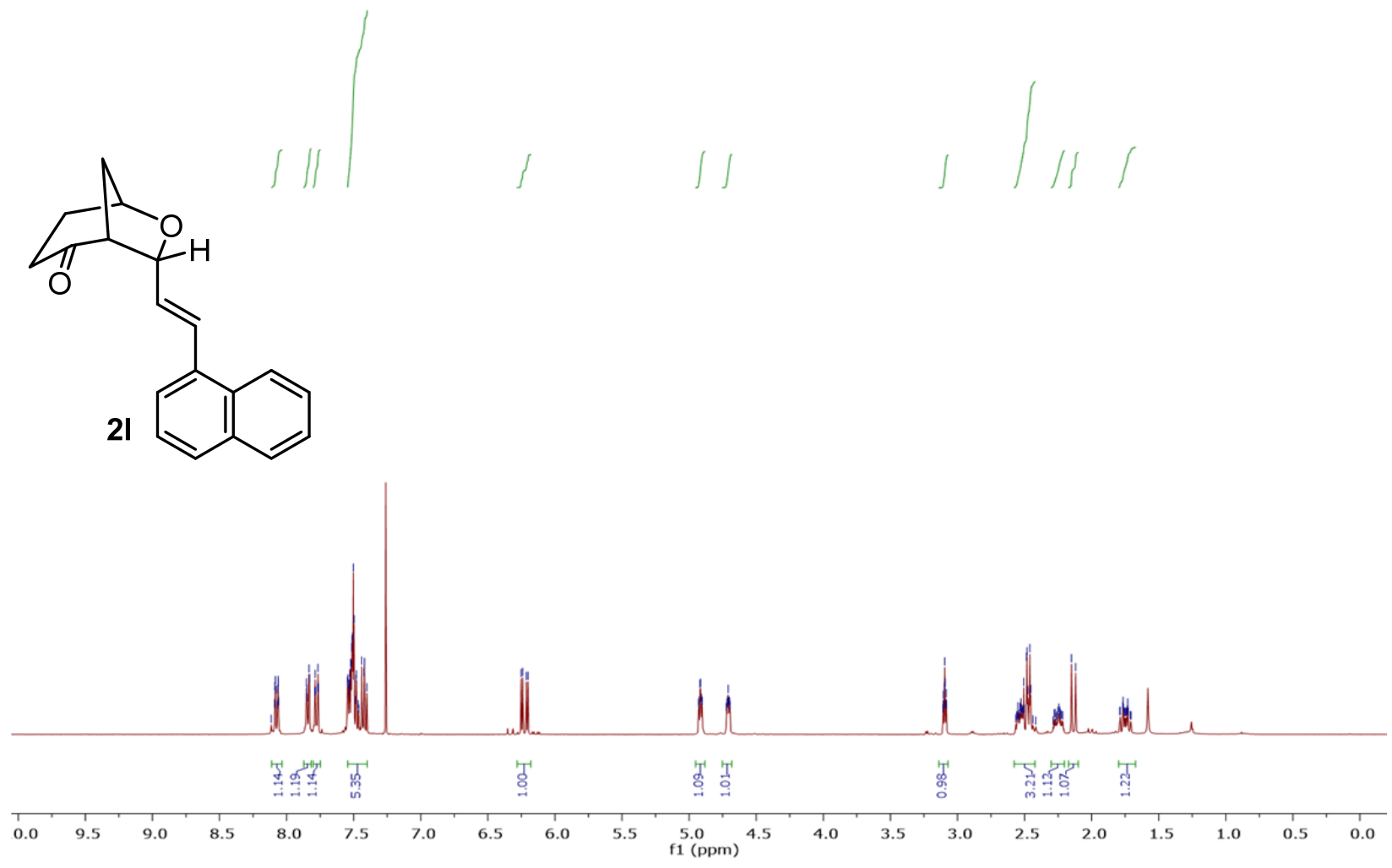

息
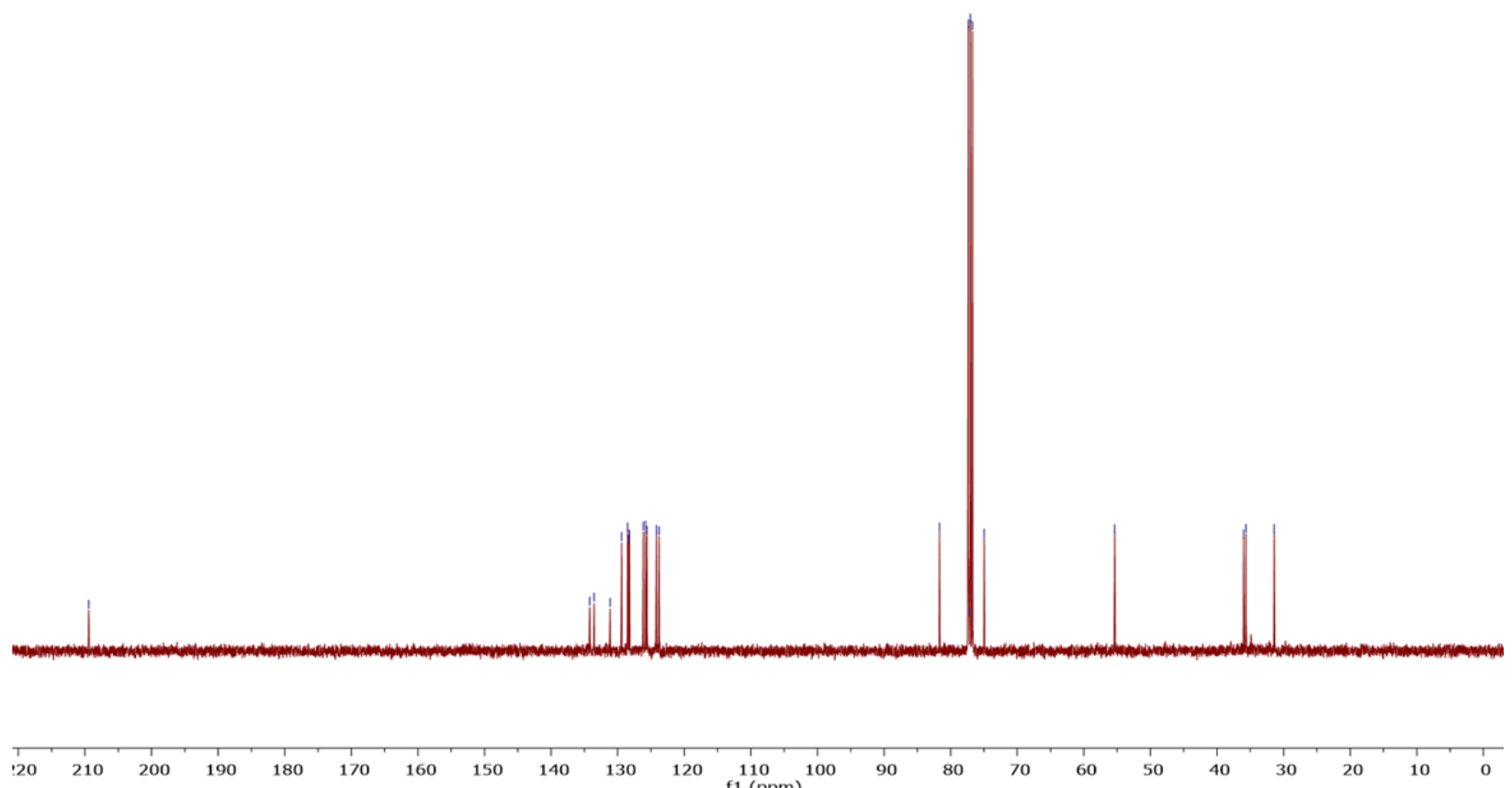


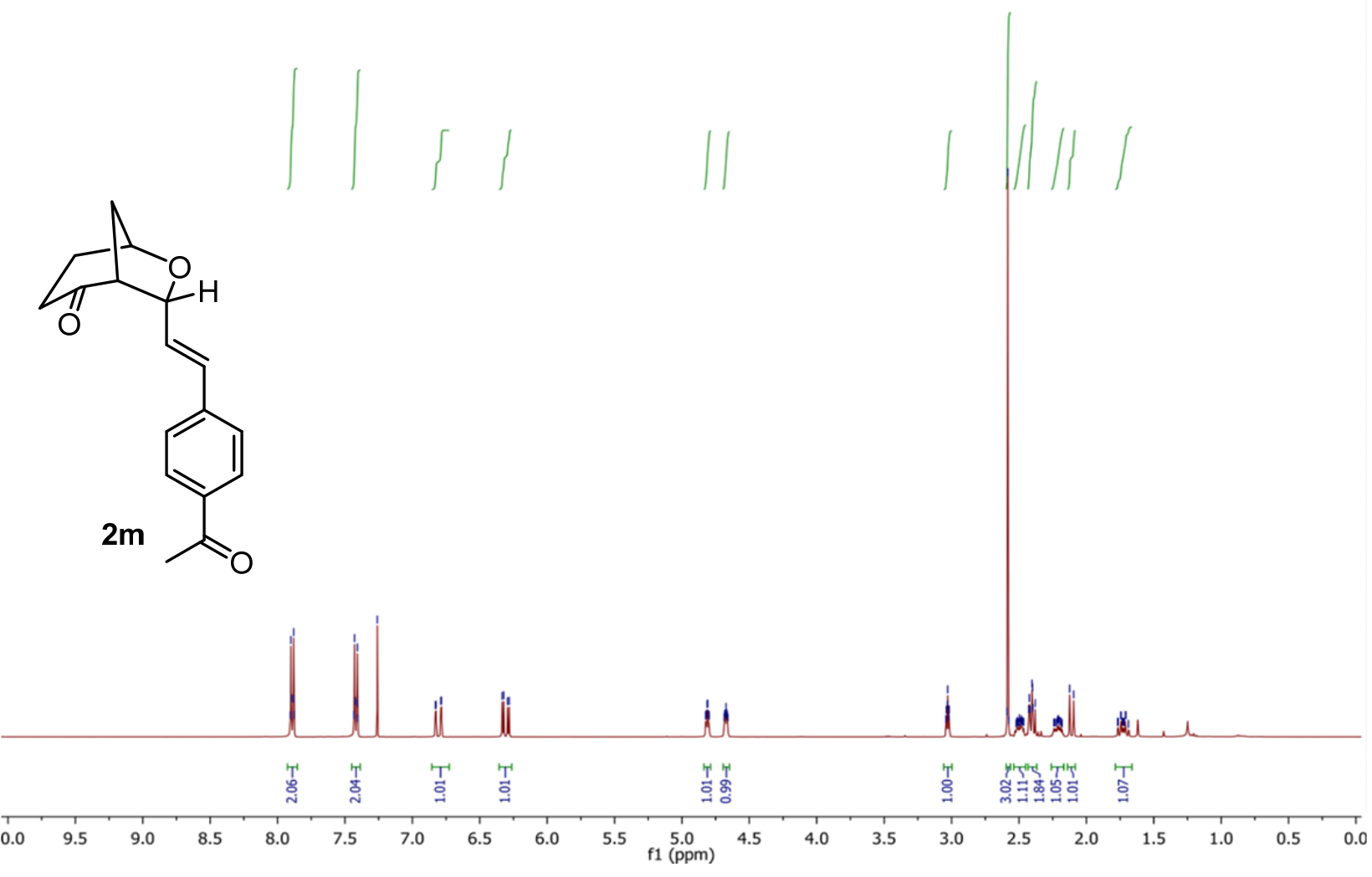

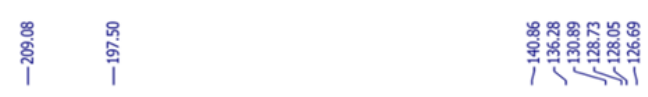

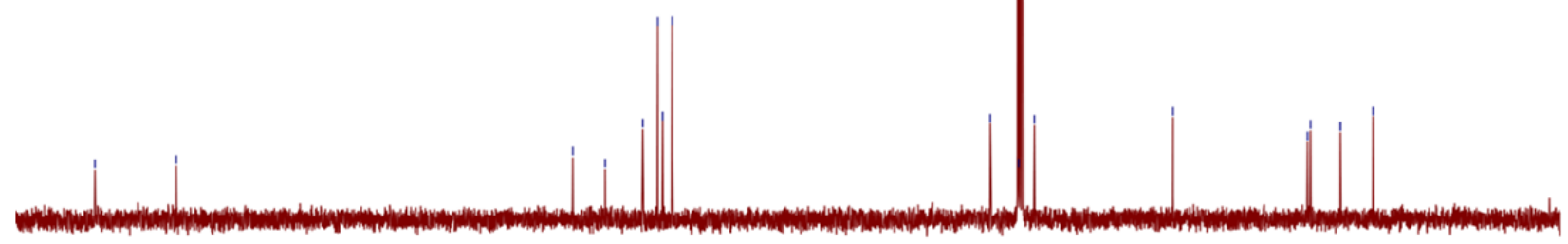

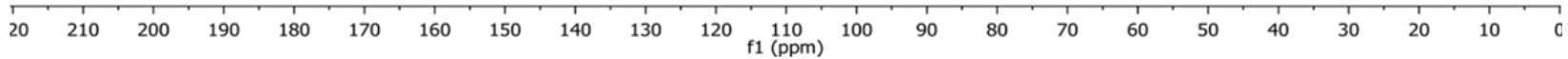



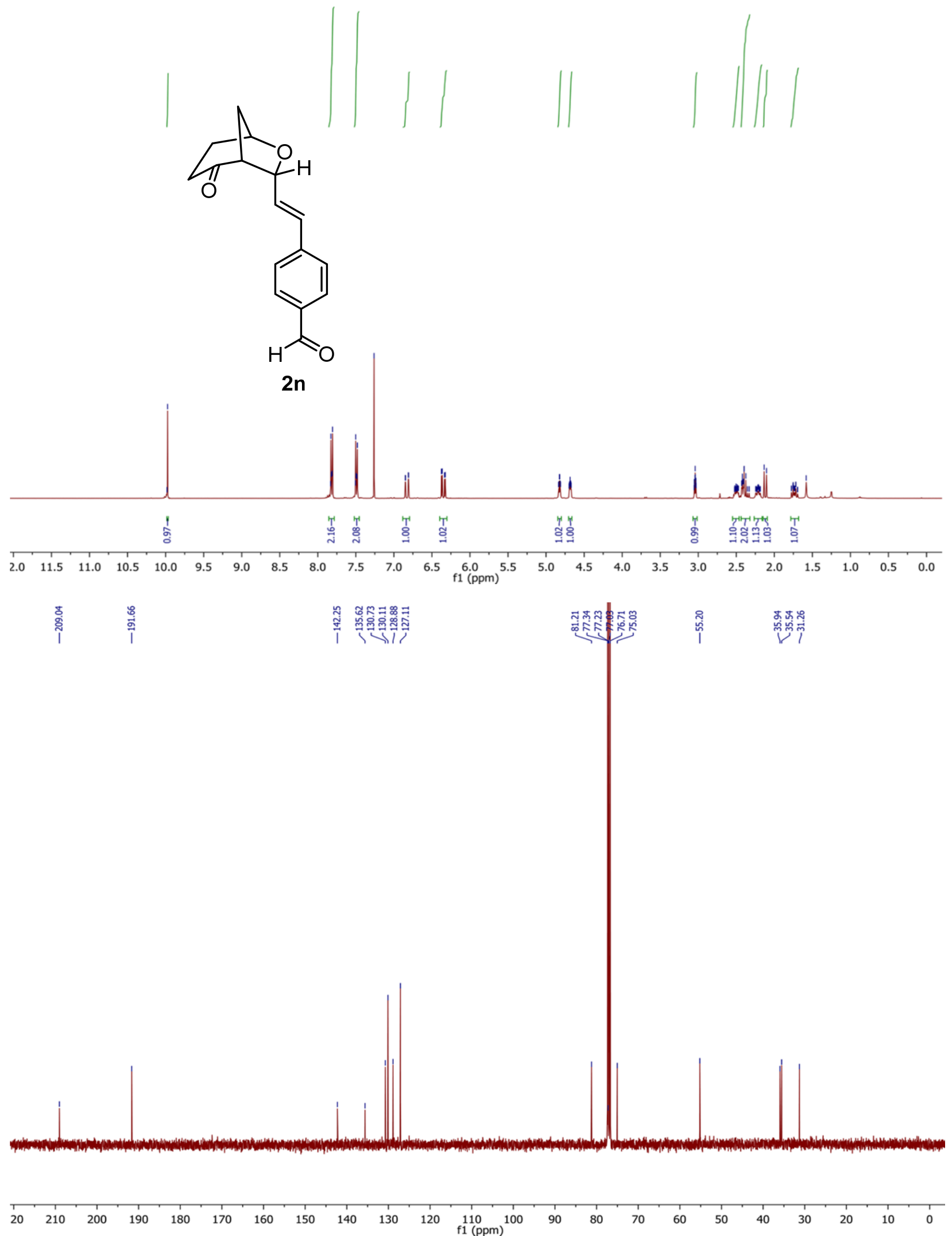


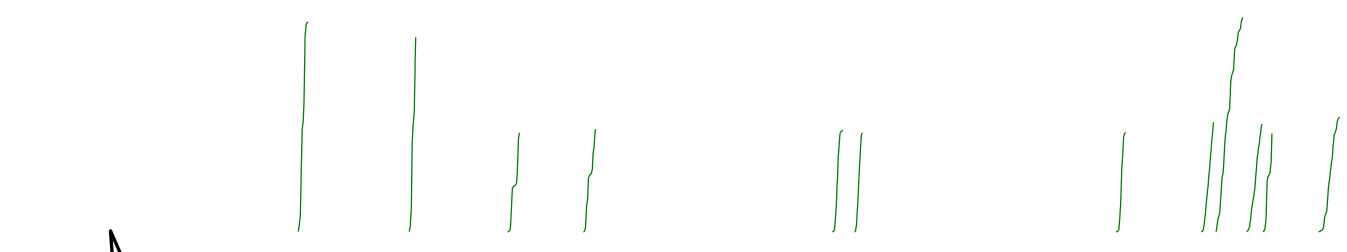<smiles>O=C1CCC2CC1OC2/C=C/c1ccc([N+](=O)[O-])cc1</smiles>
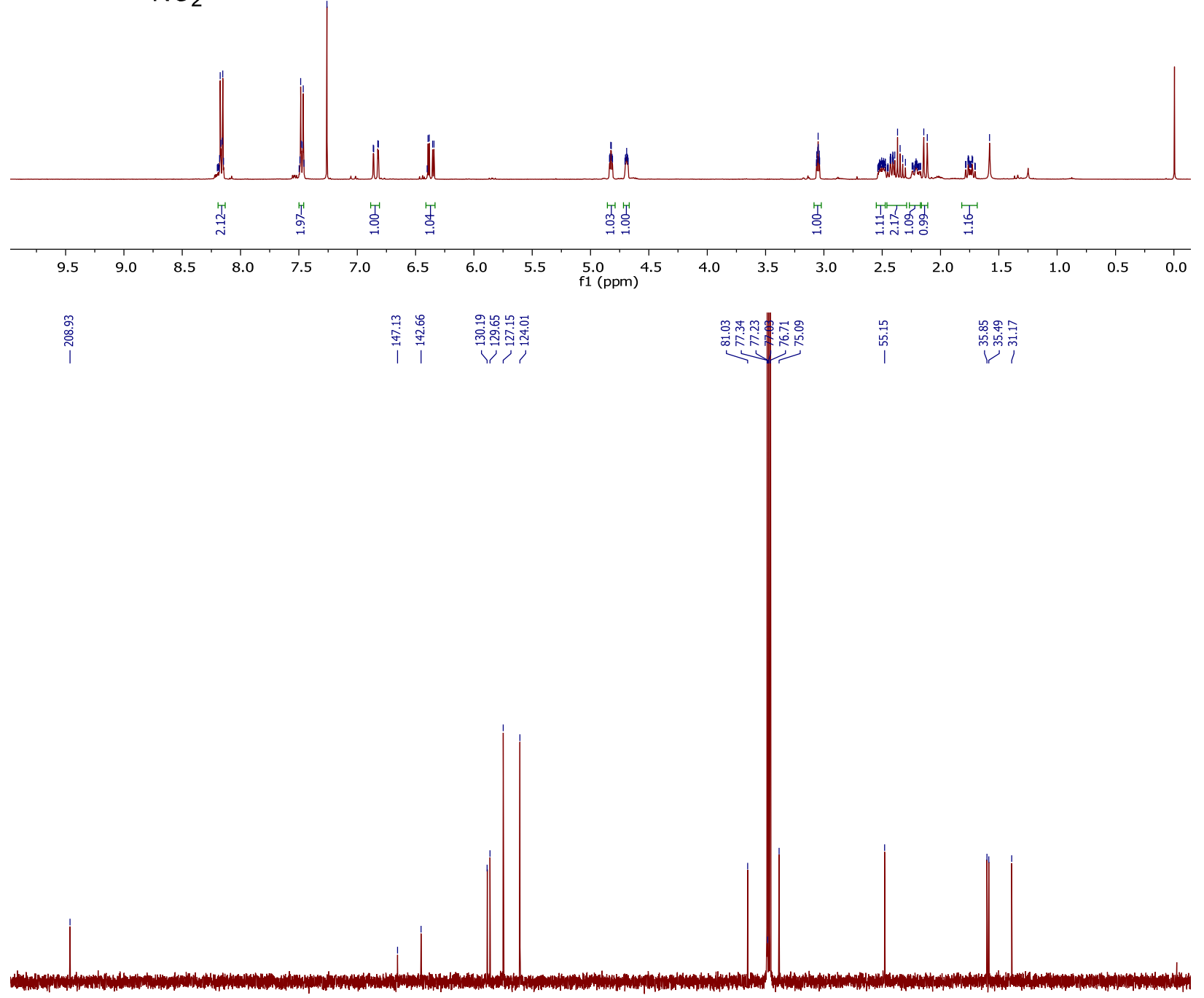

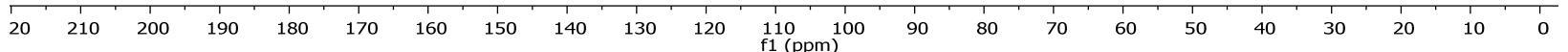




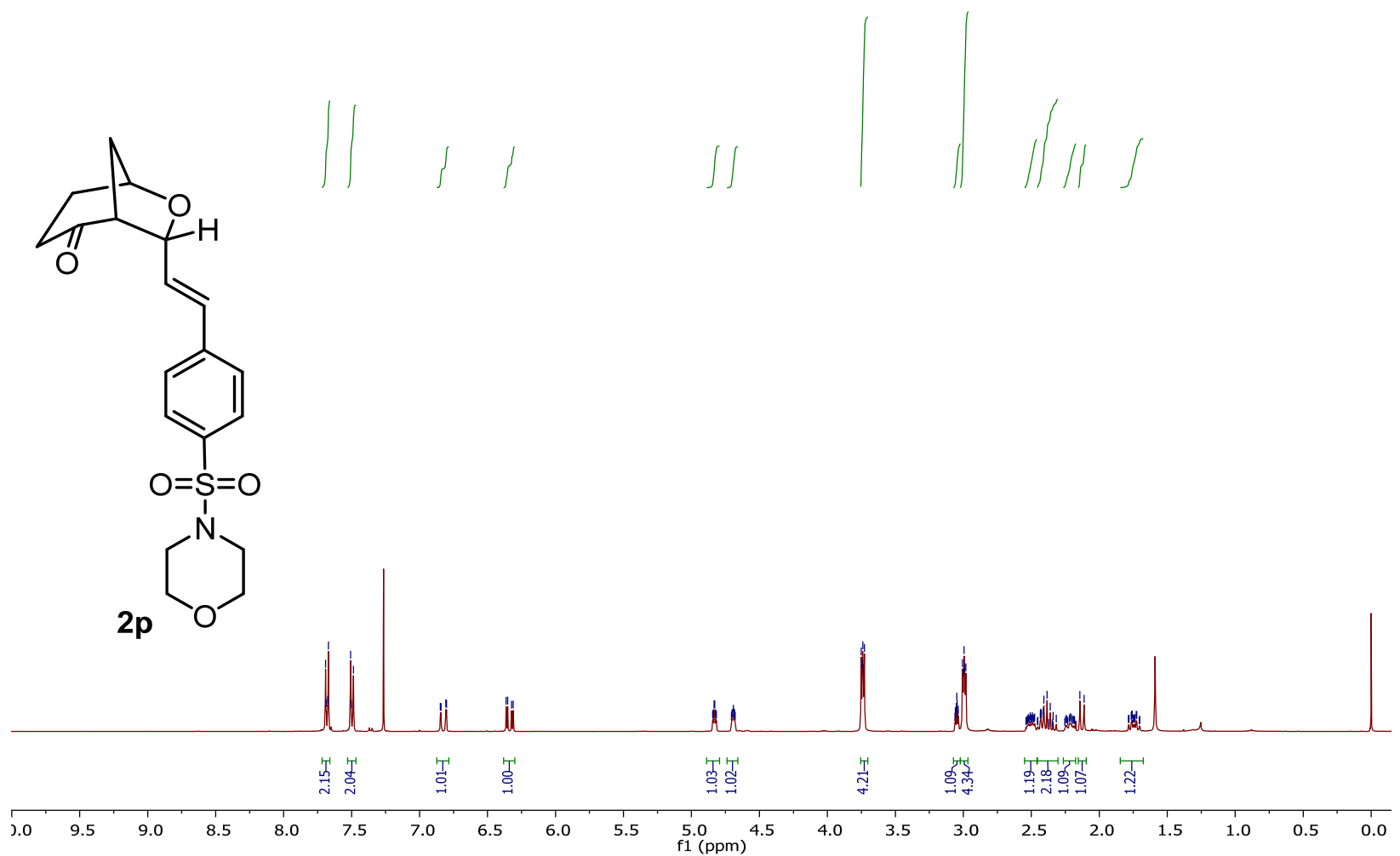

dong-106-63-3--nnn.10.fid

宛

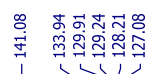

诲

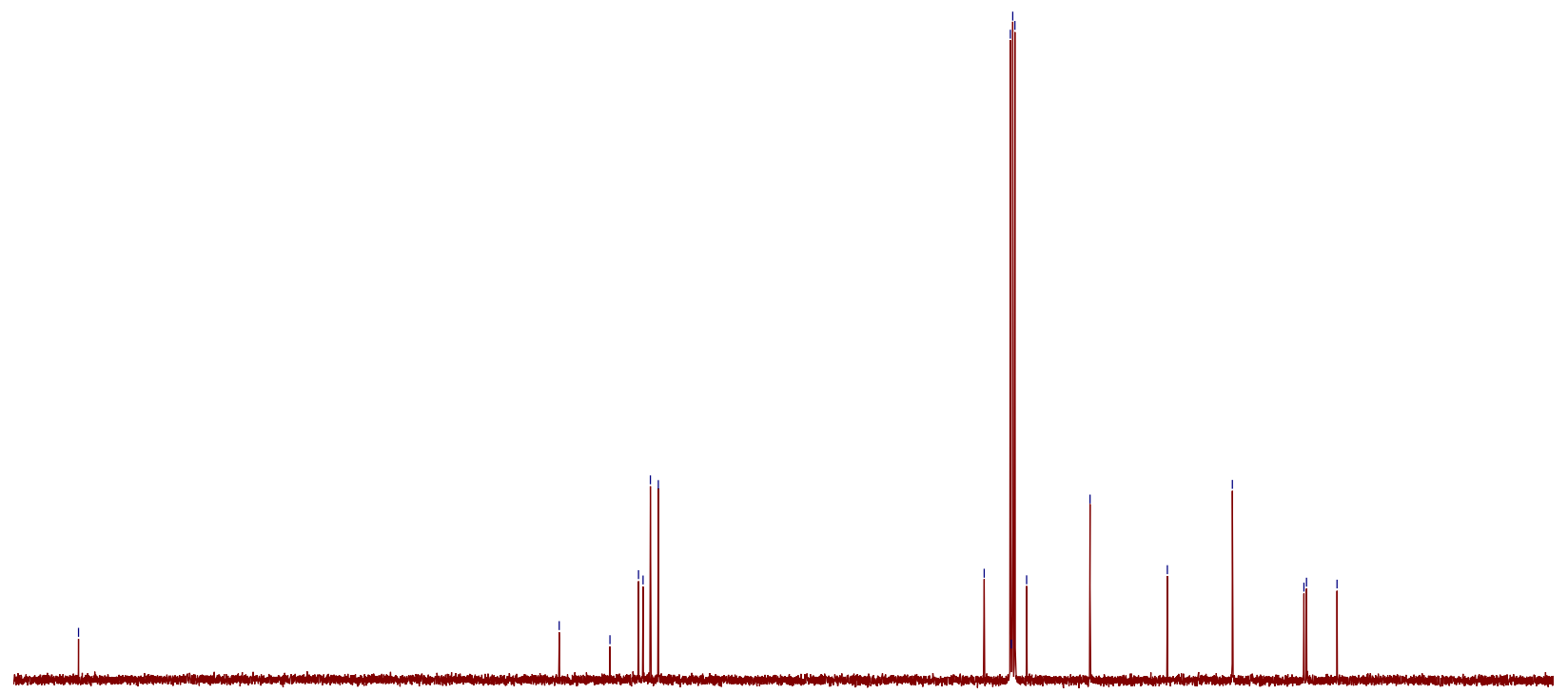

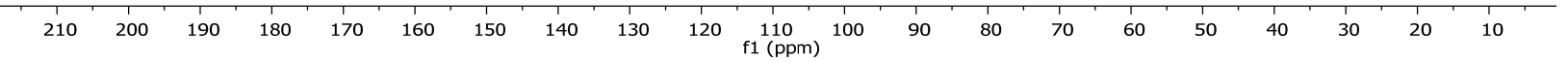




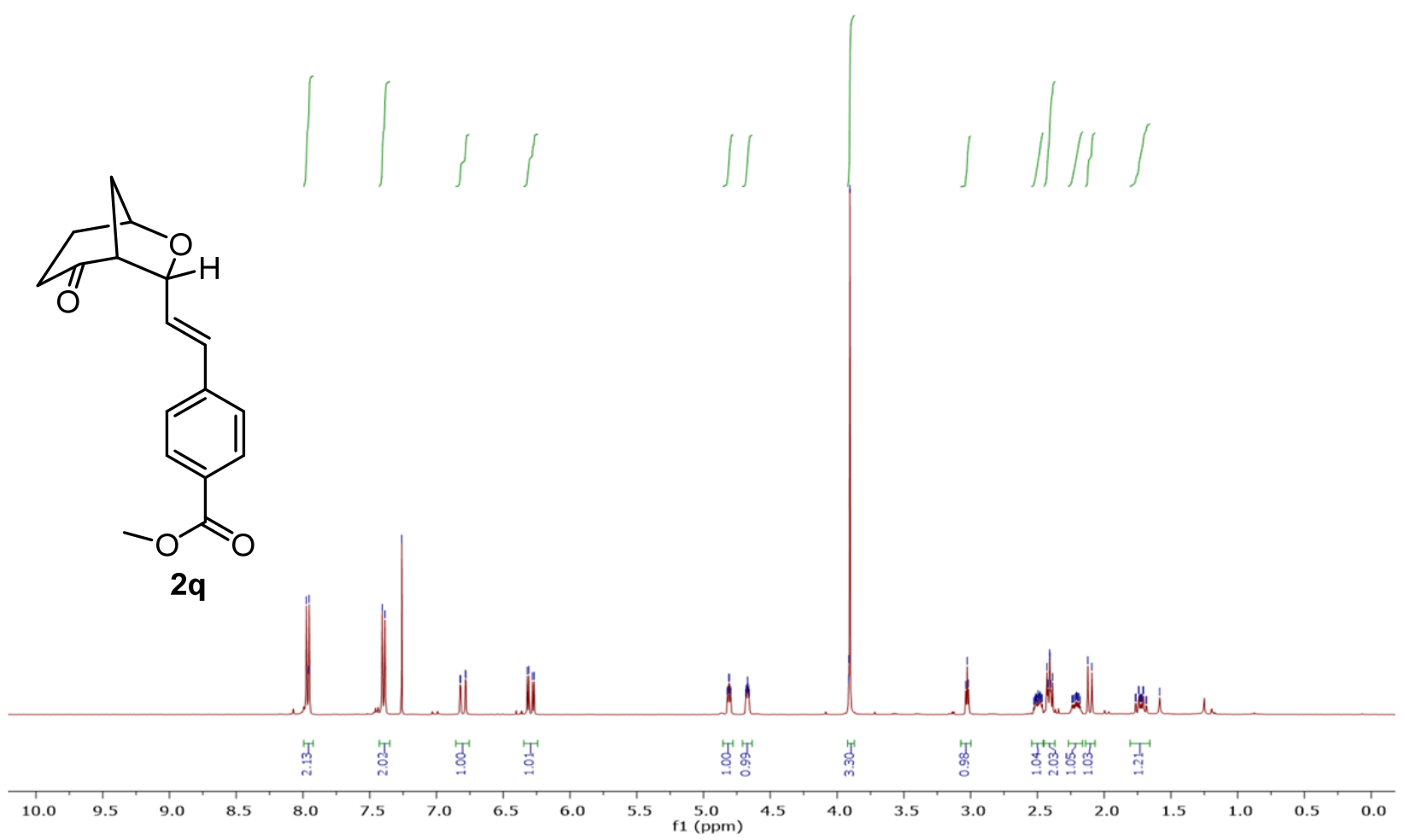

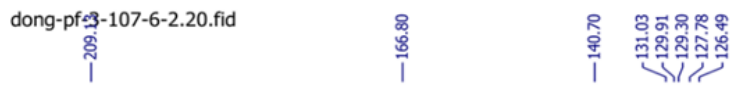

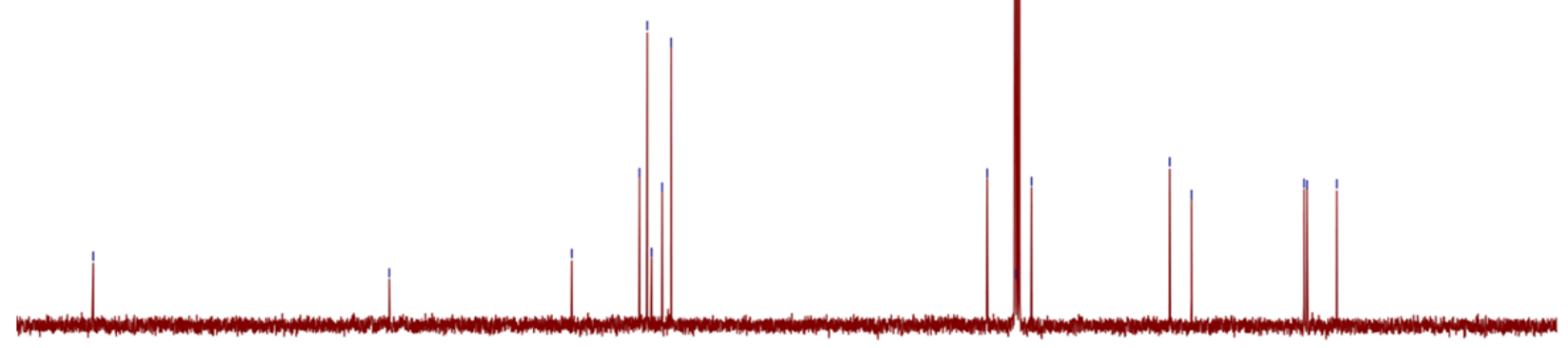

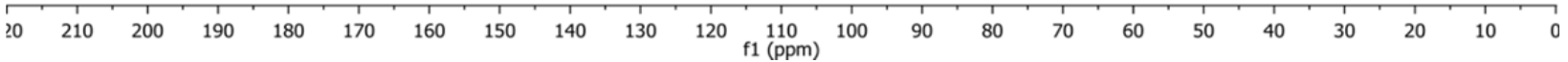



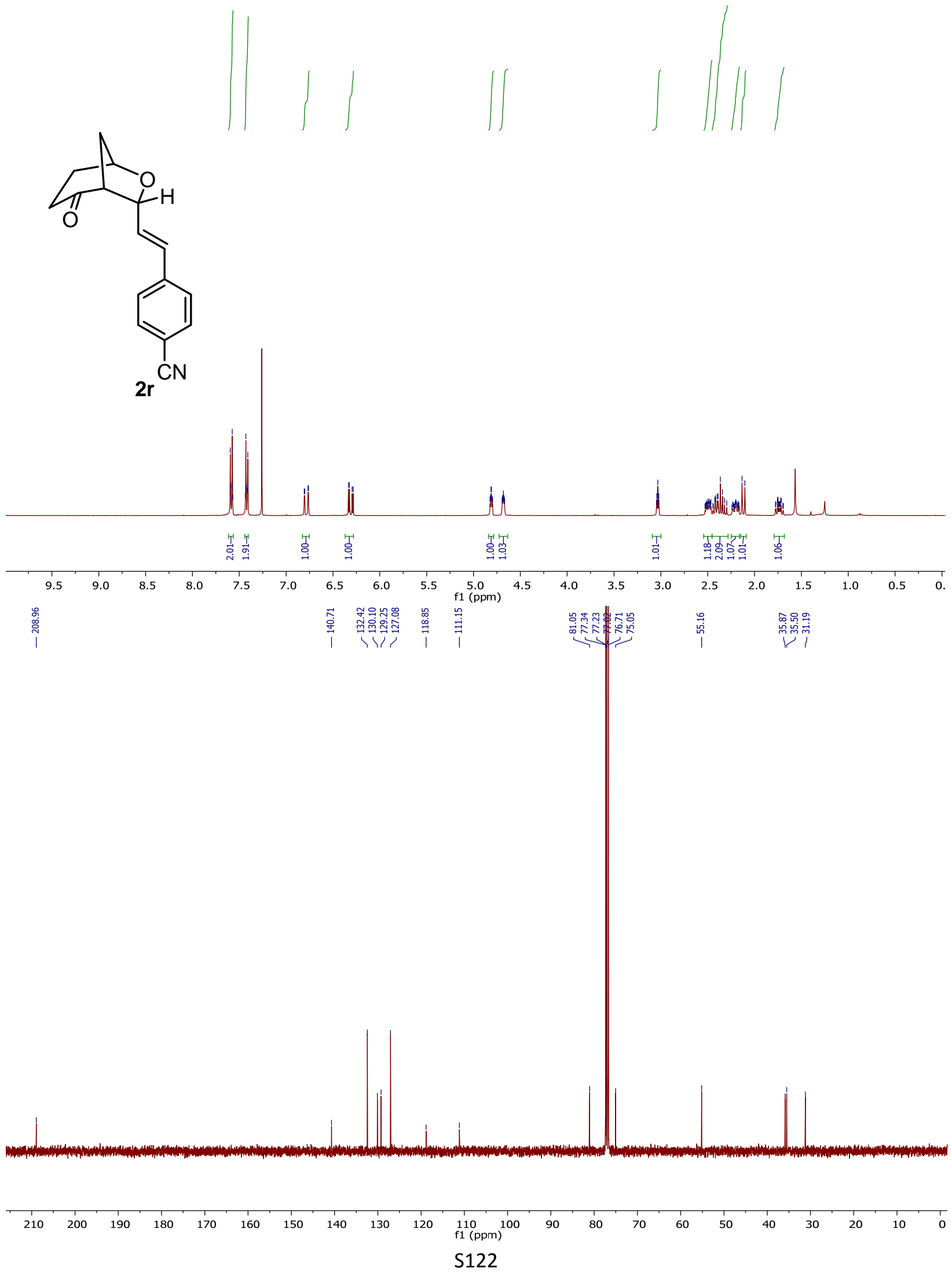
<smiles>CC(C)(C)Oc1cccc(/C=C/C2OC3CCC(=O)C2C3)c1</smiles>

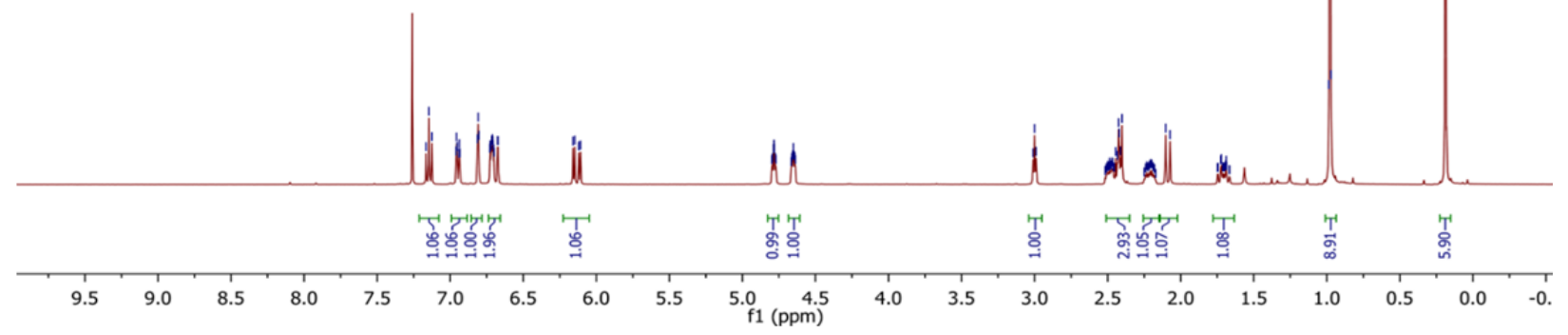

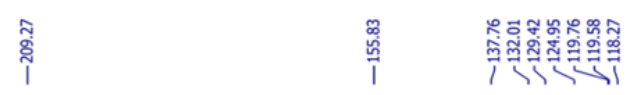
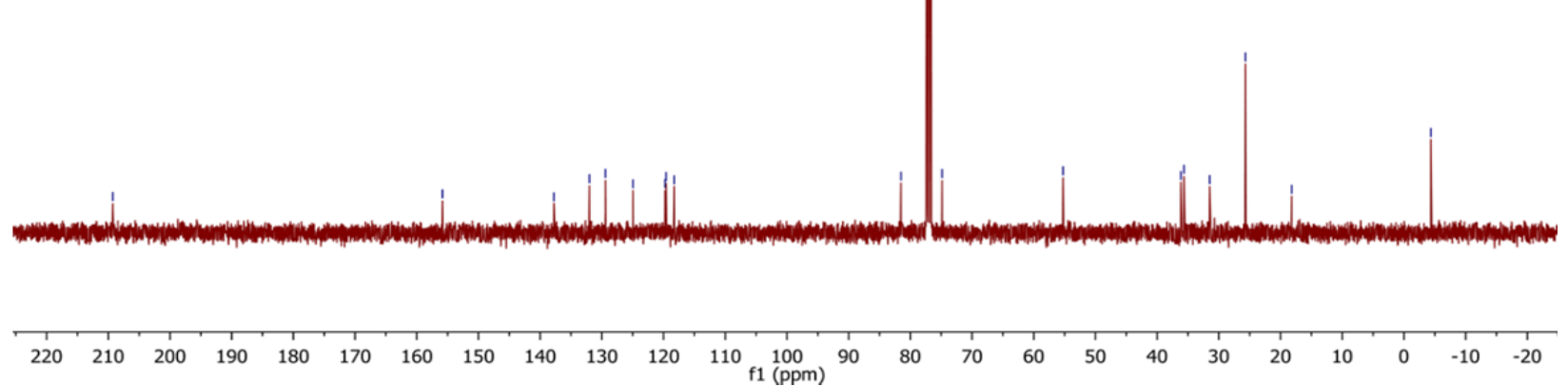

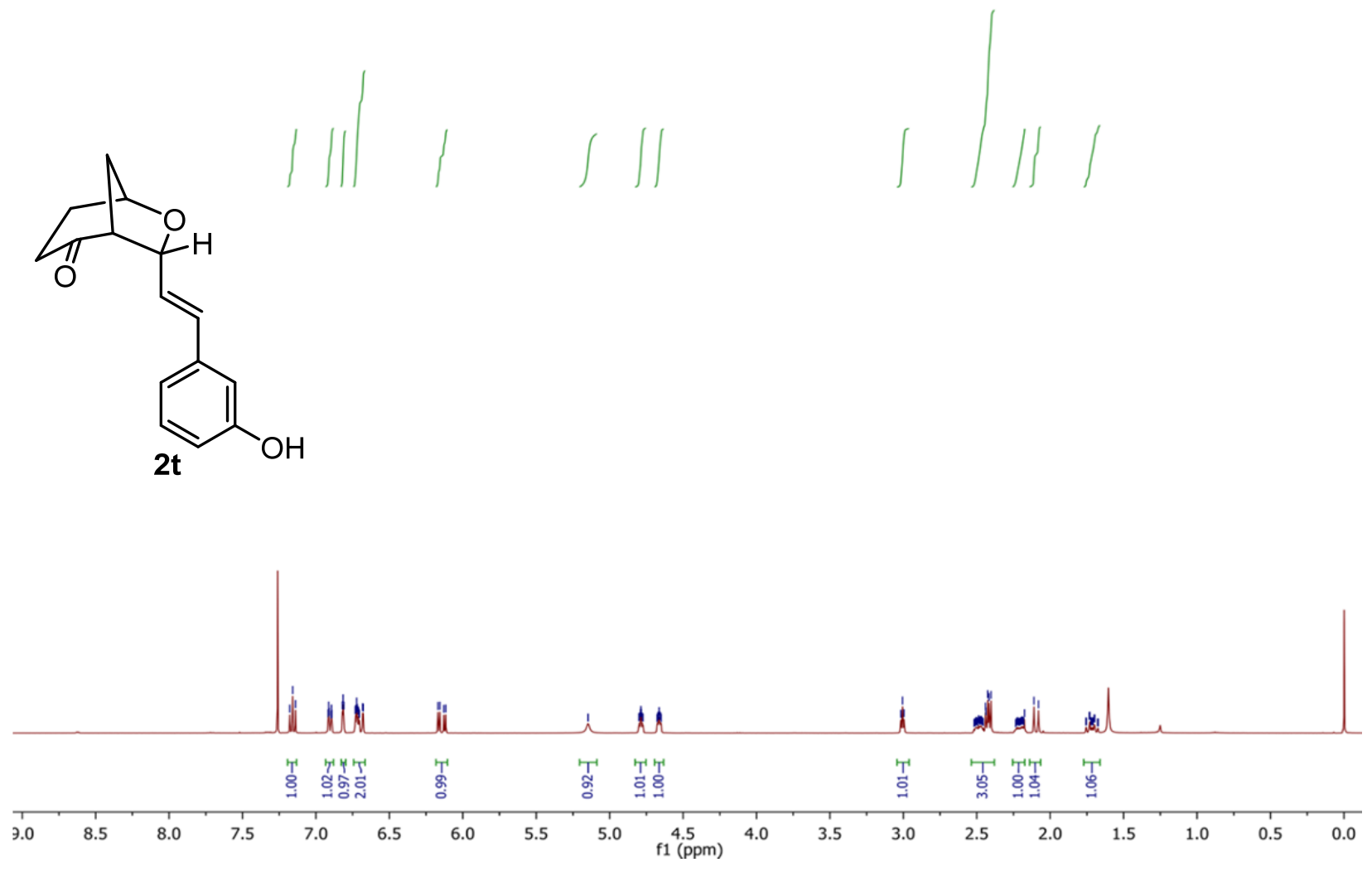

dong-pfः3-63-2-nnnn.20.fid |

क्षै
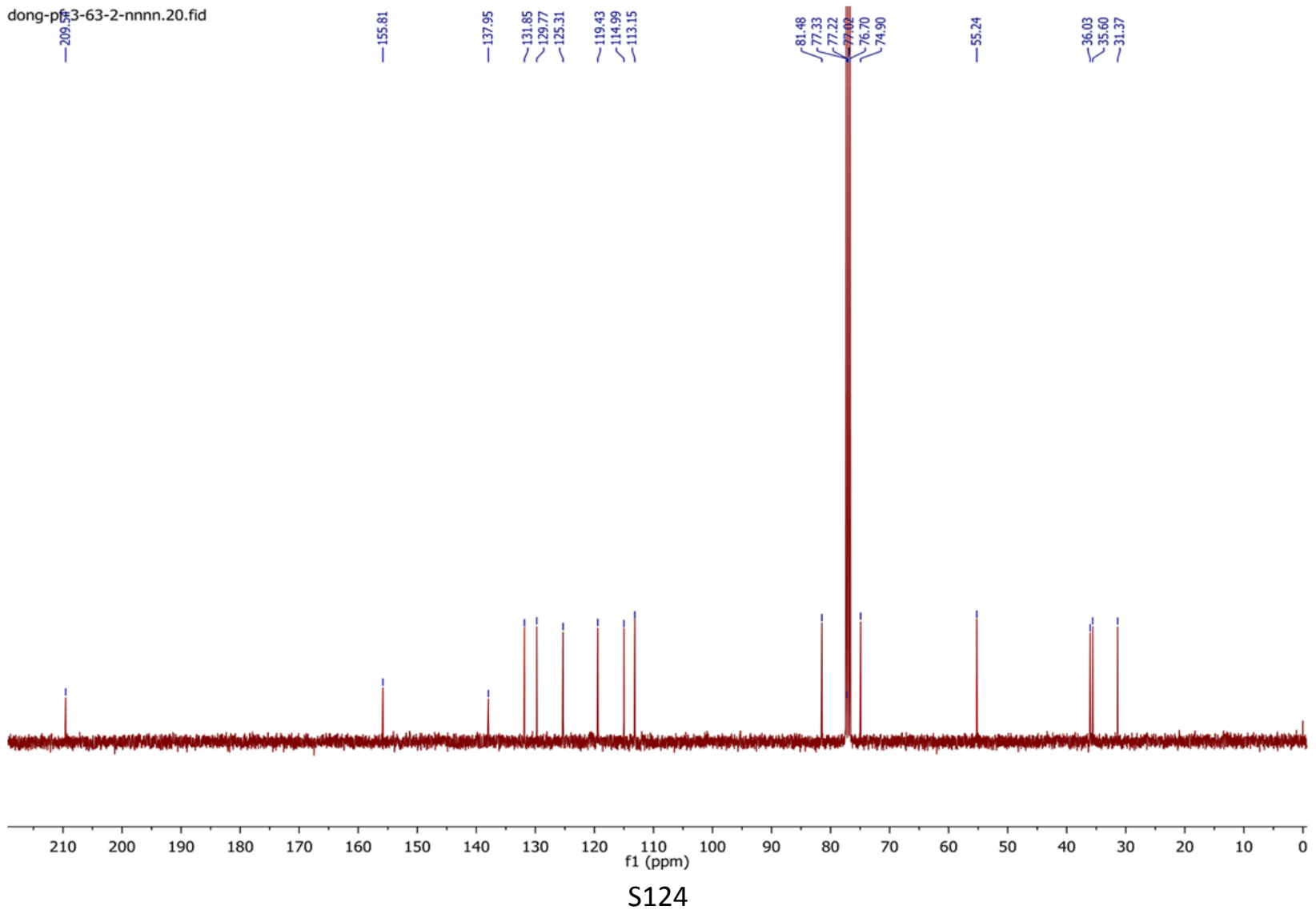


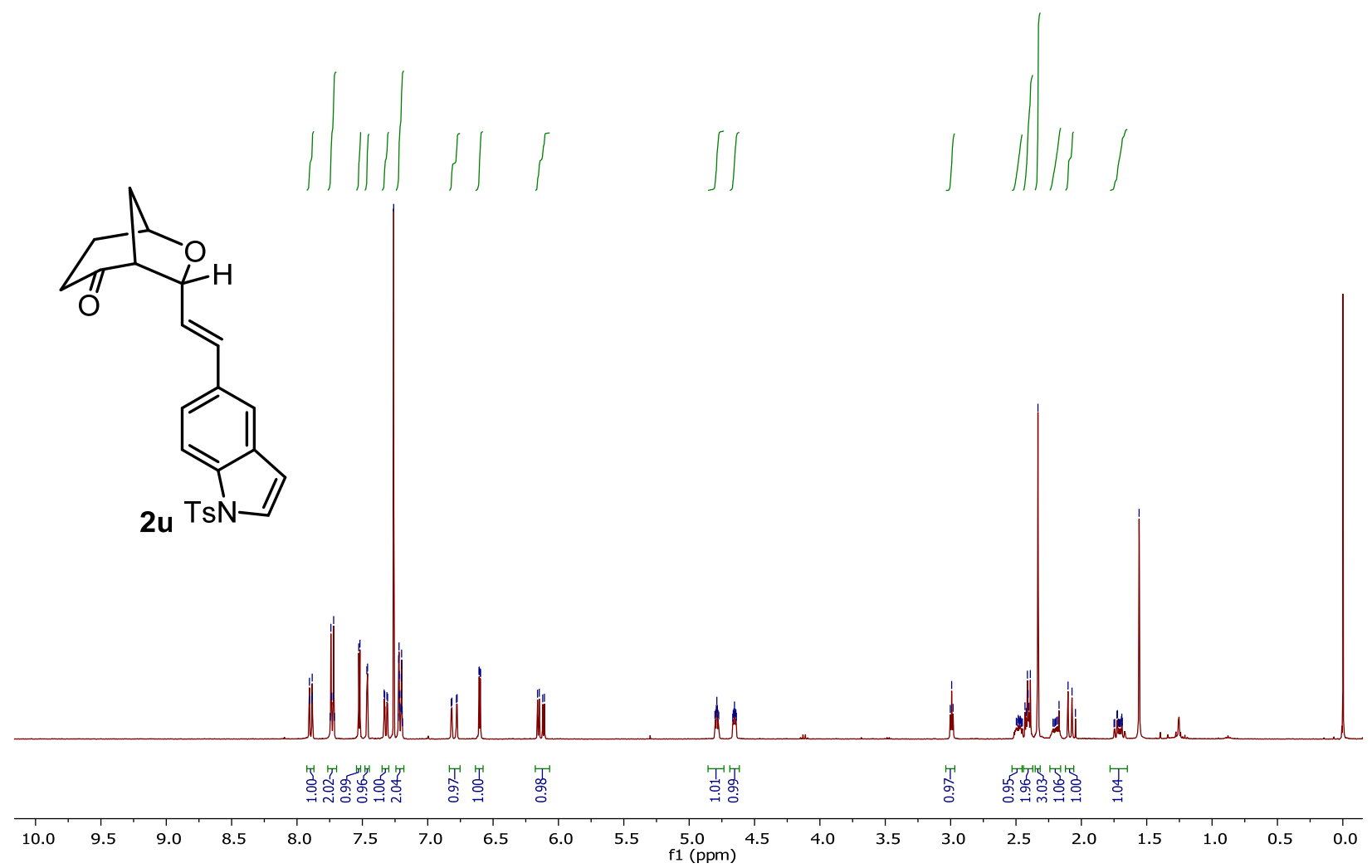

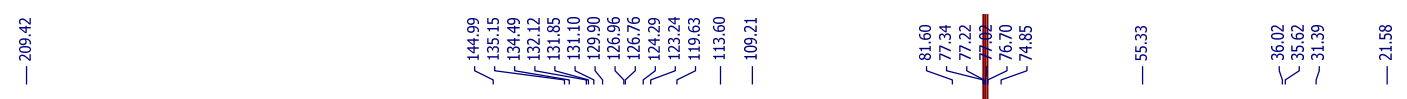
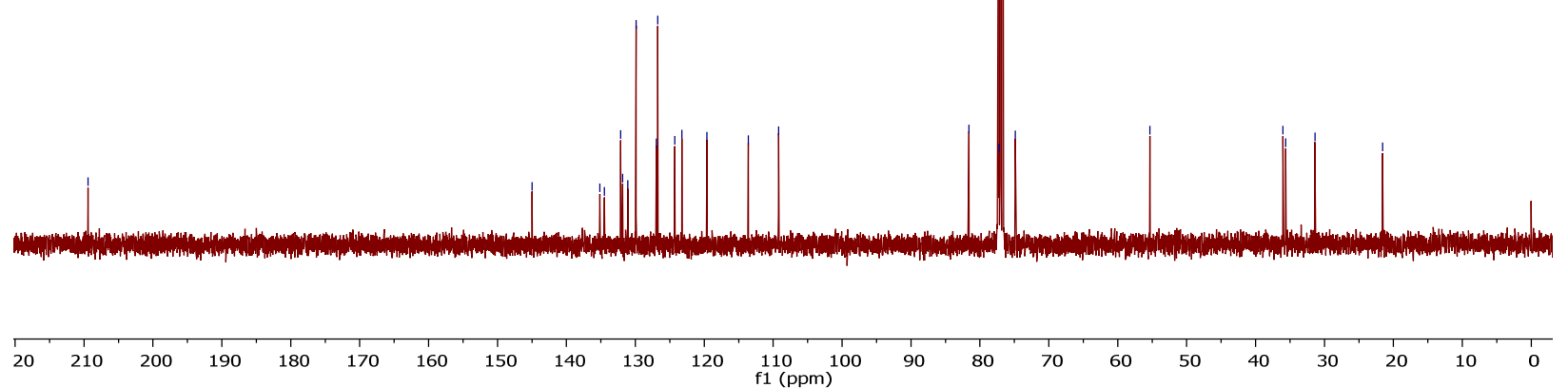

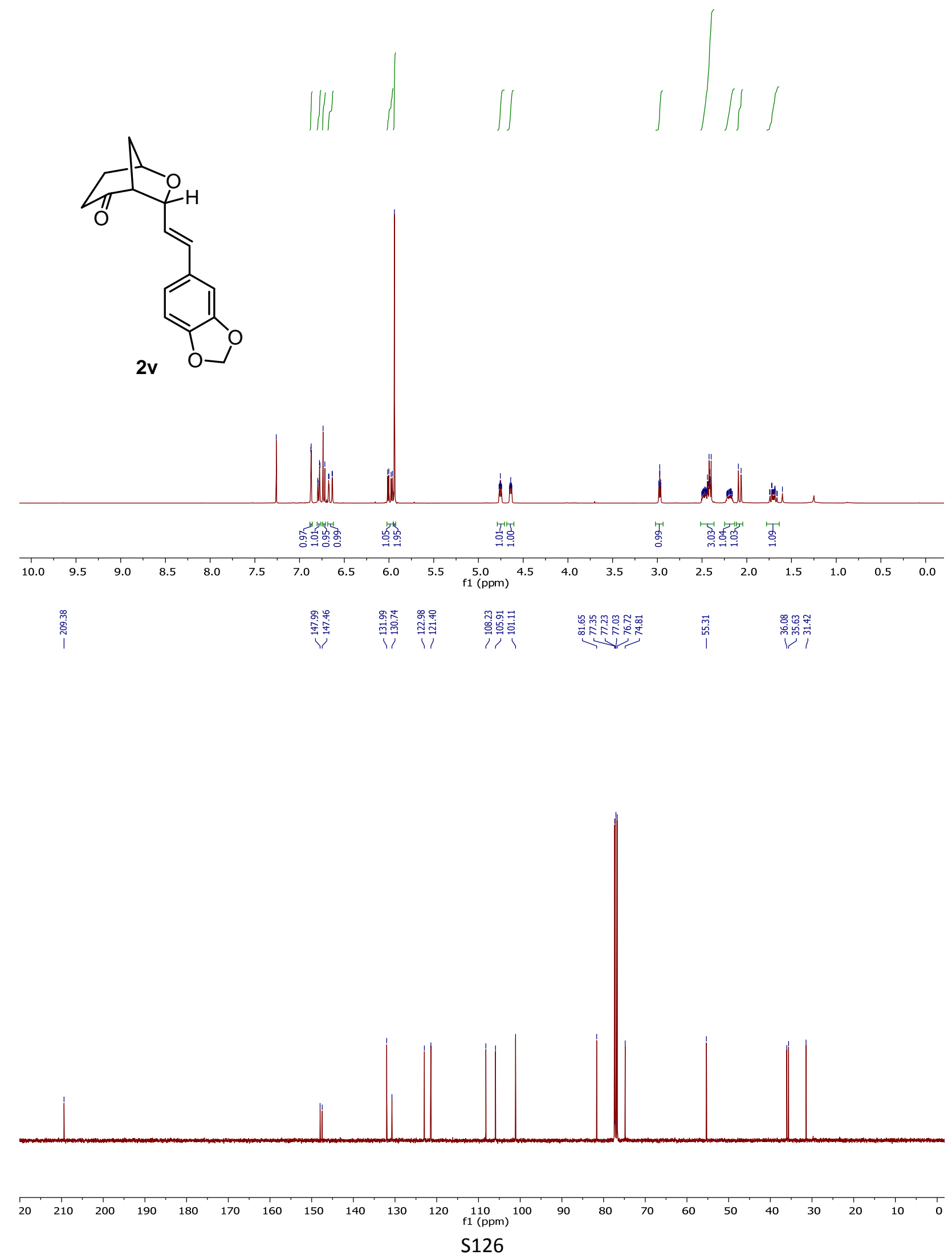

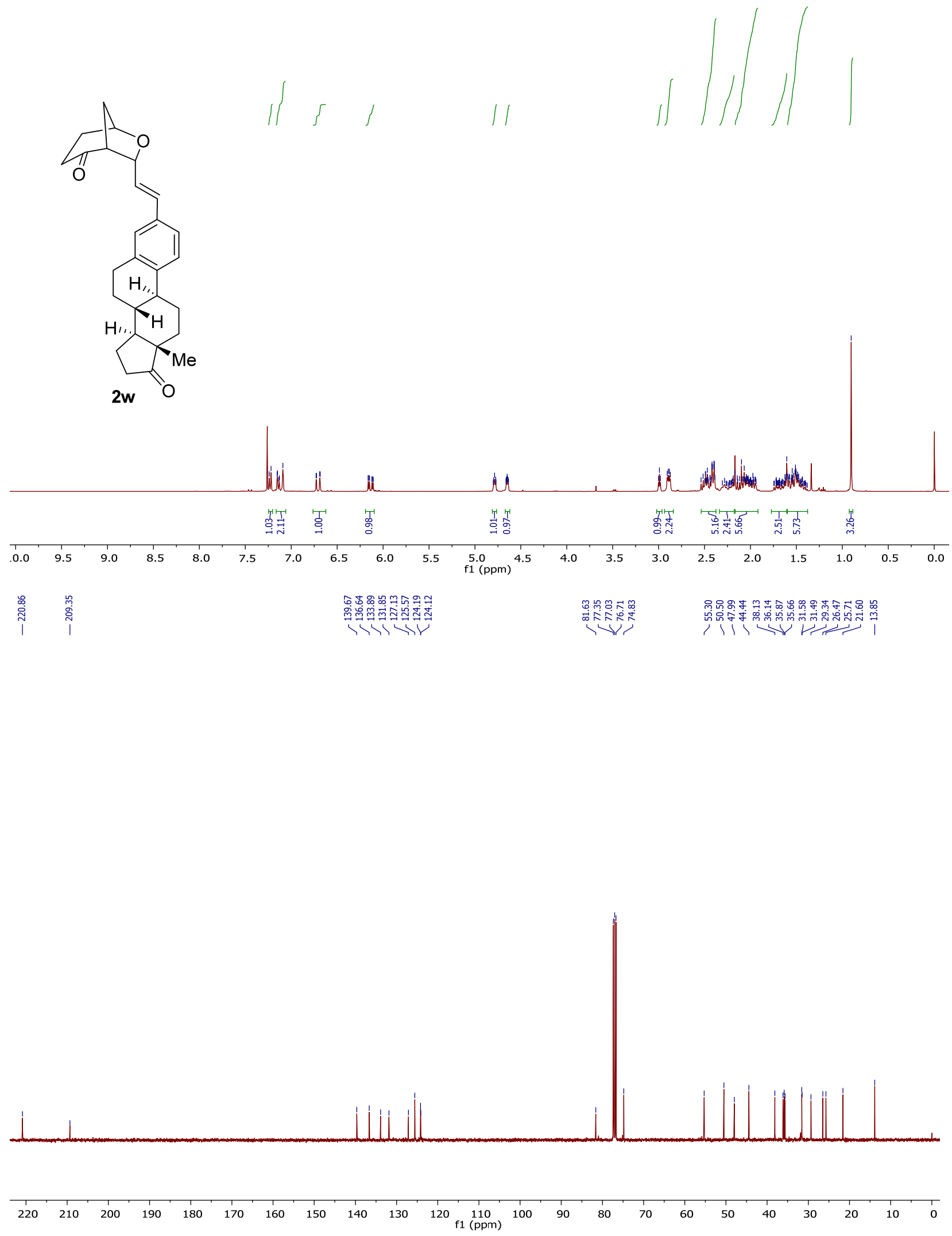


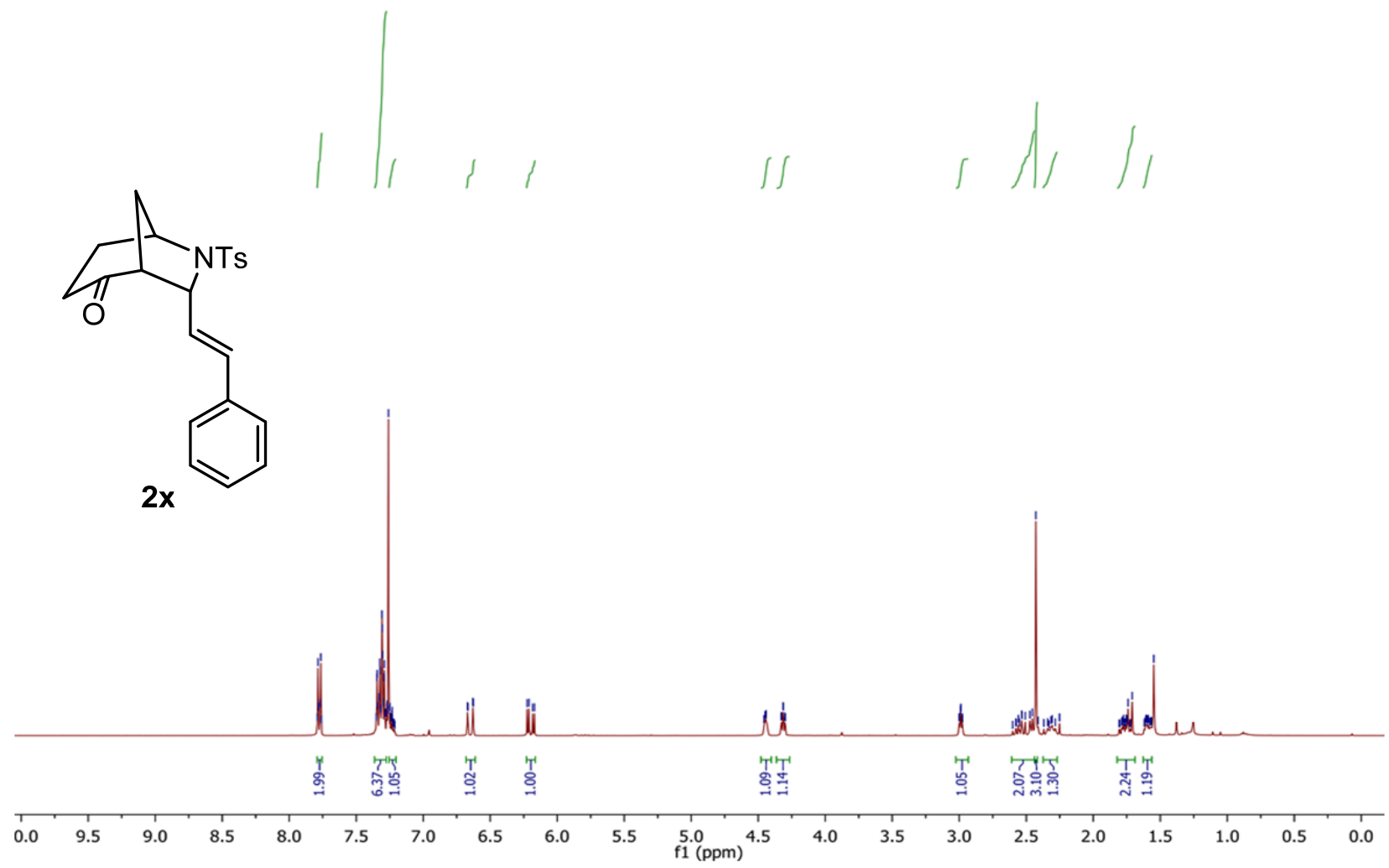

范
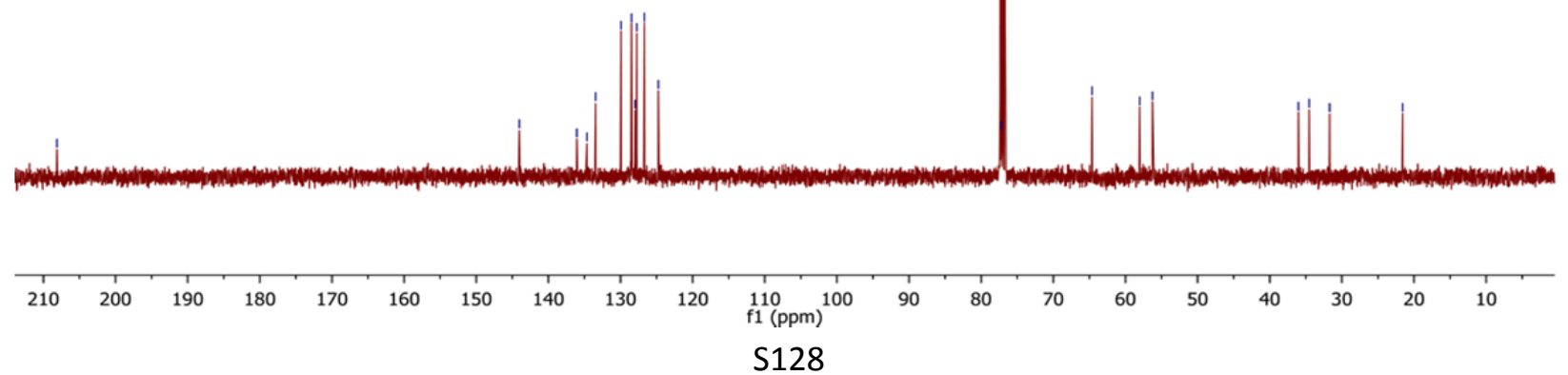


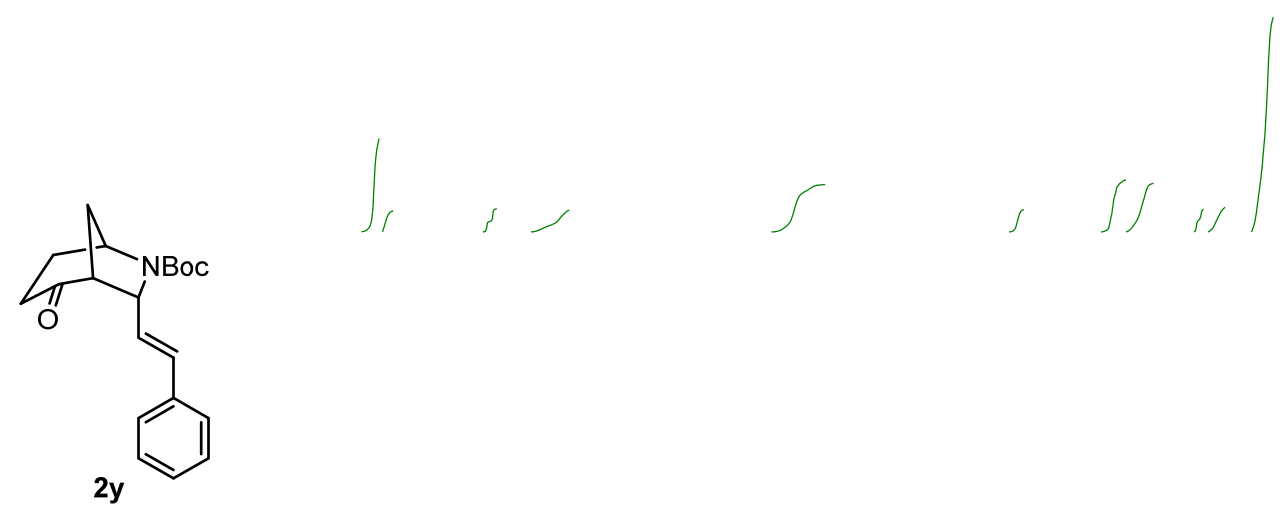

(containing rotamers)
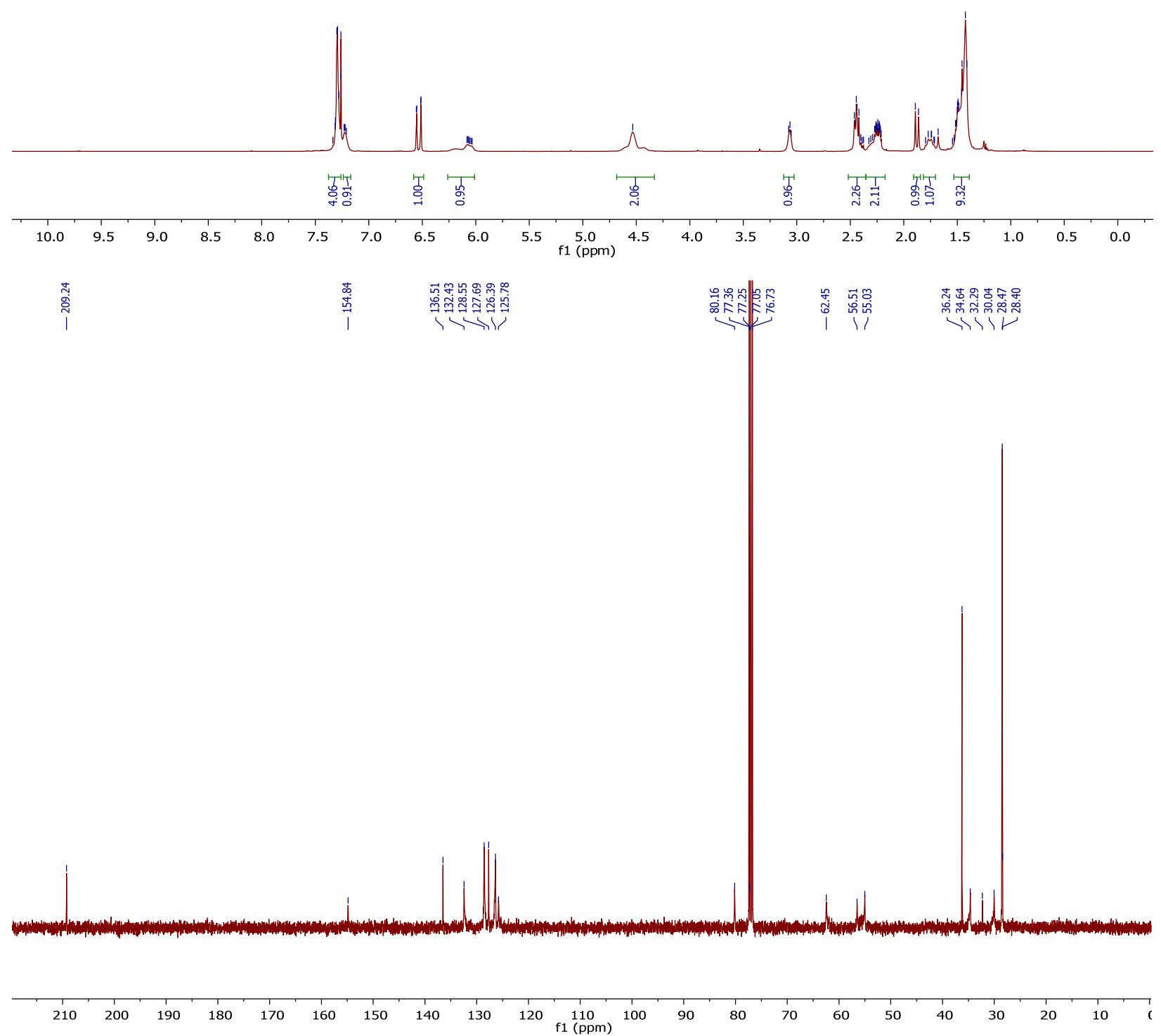

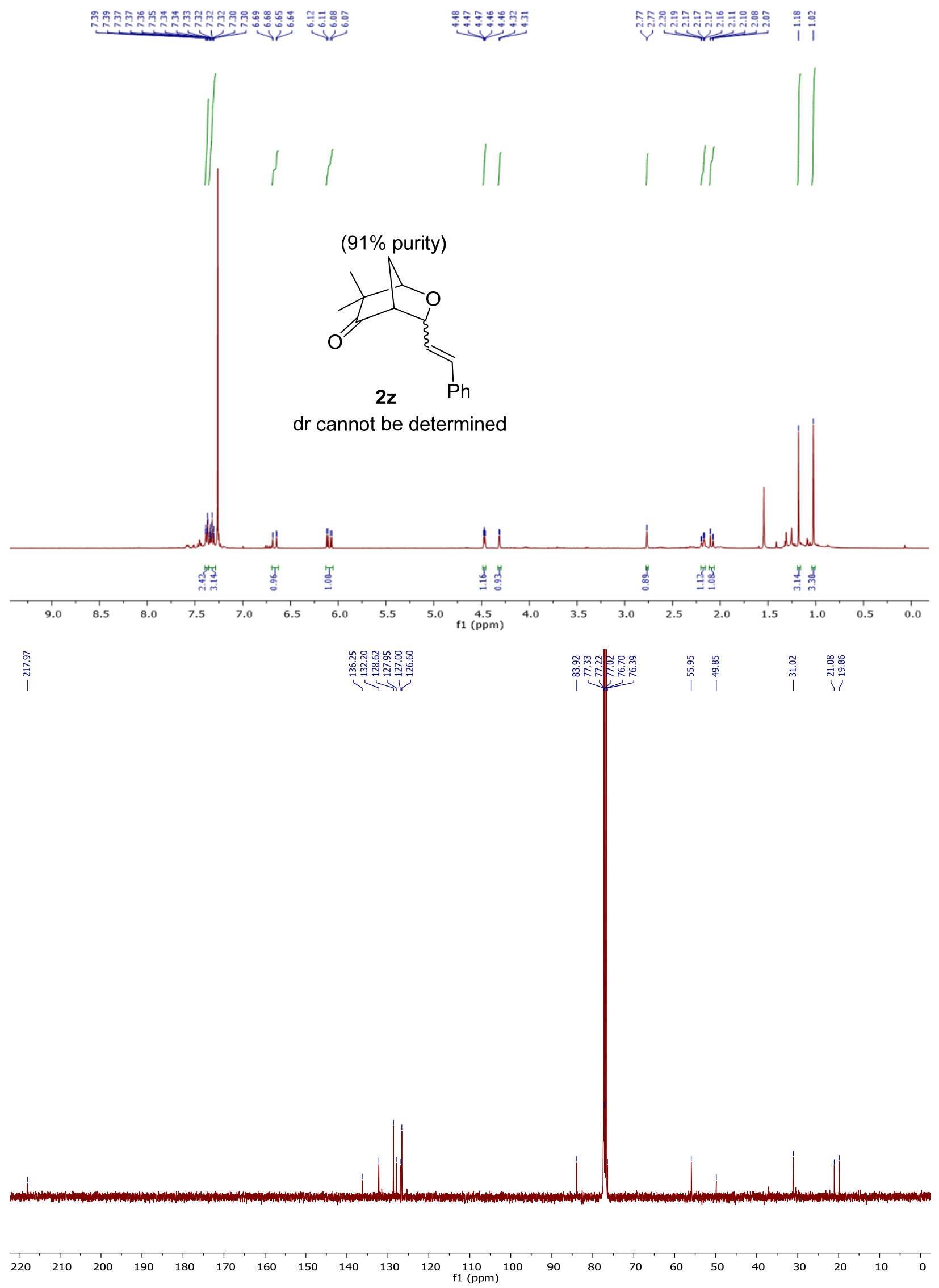

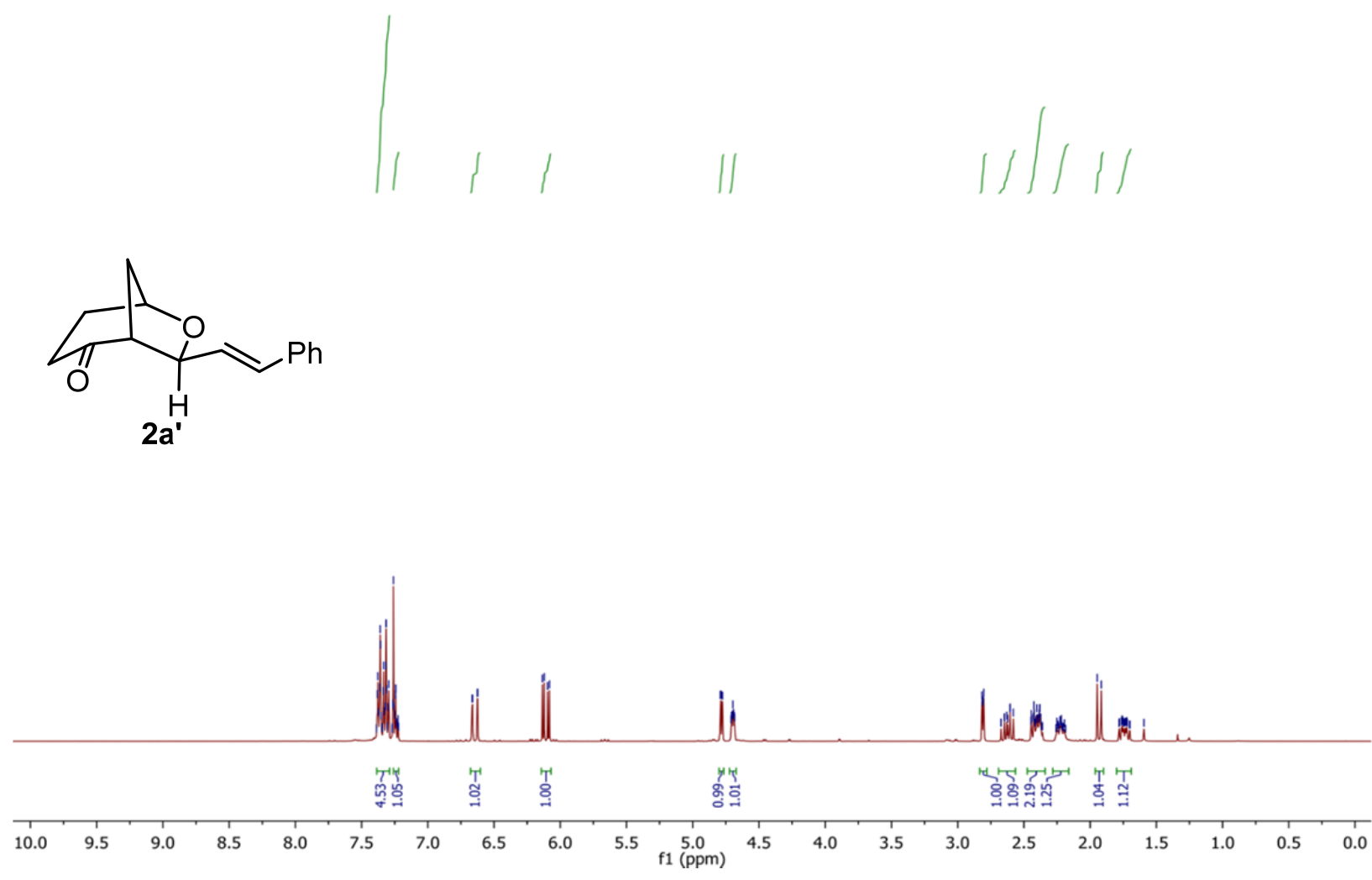

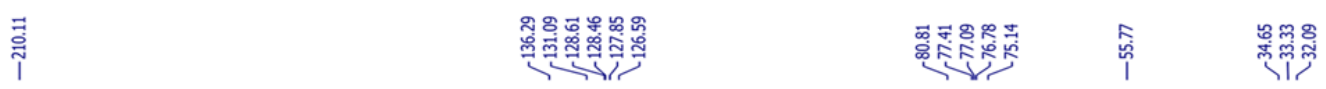

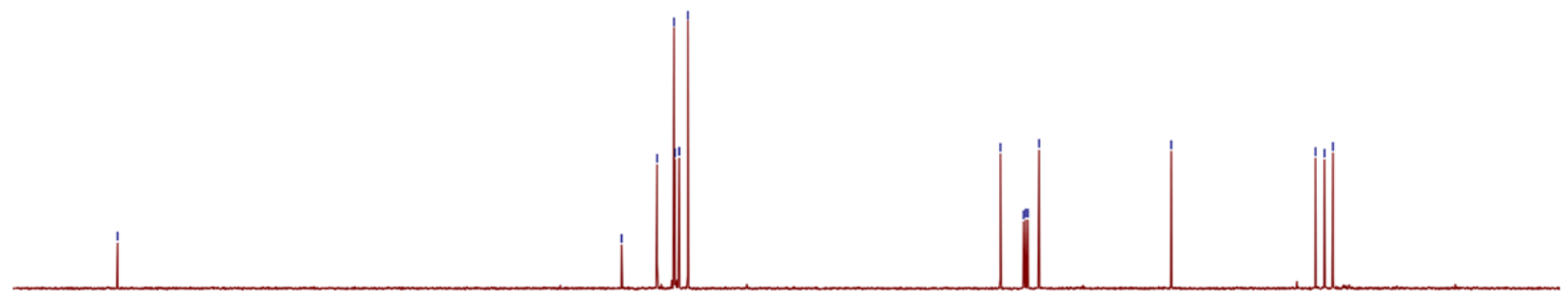

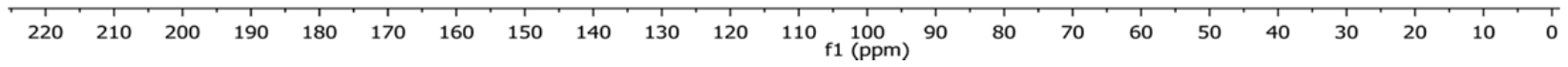
S131 

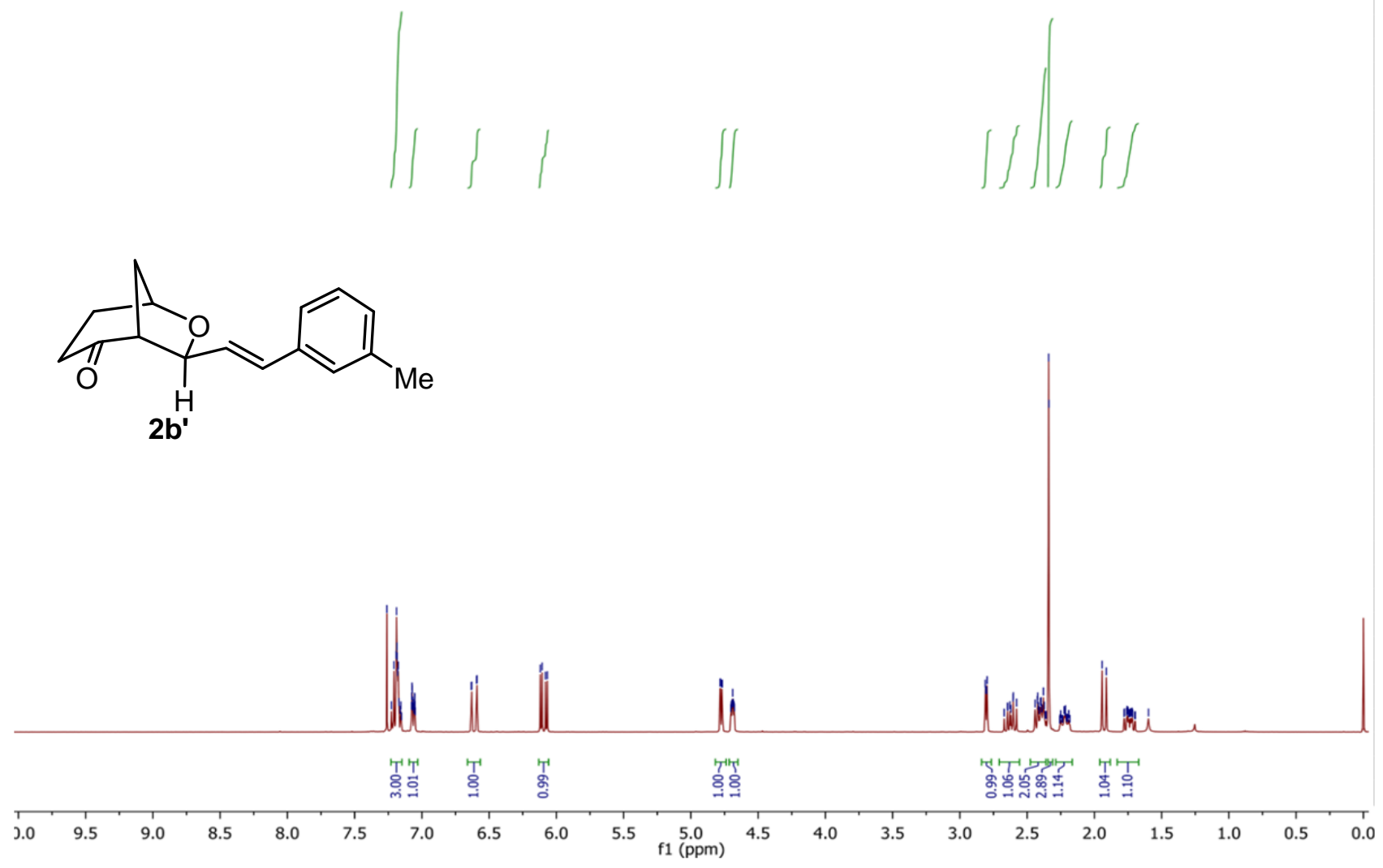

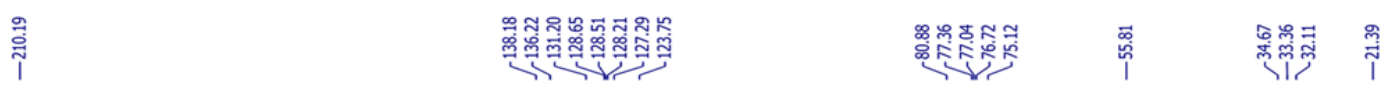

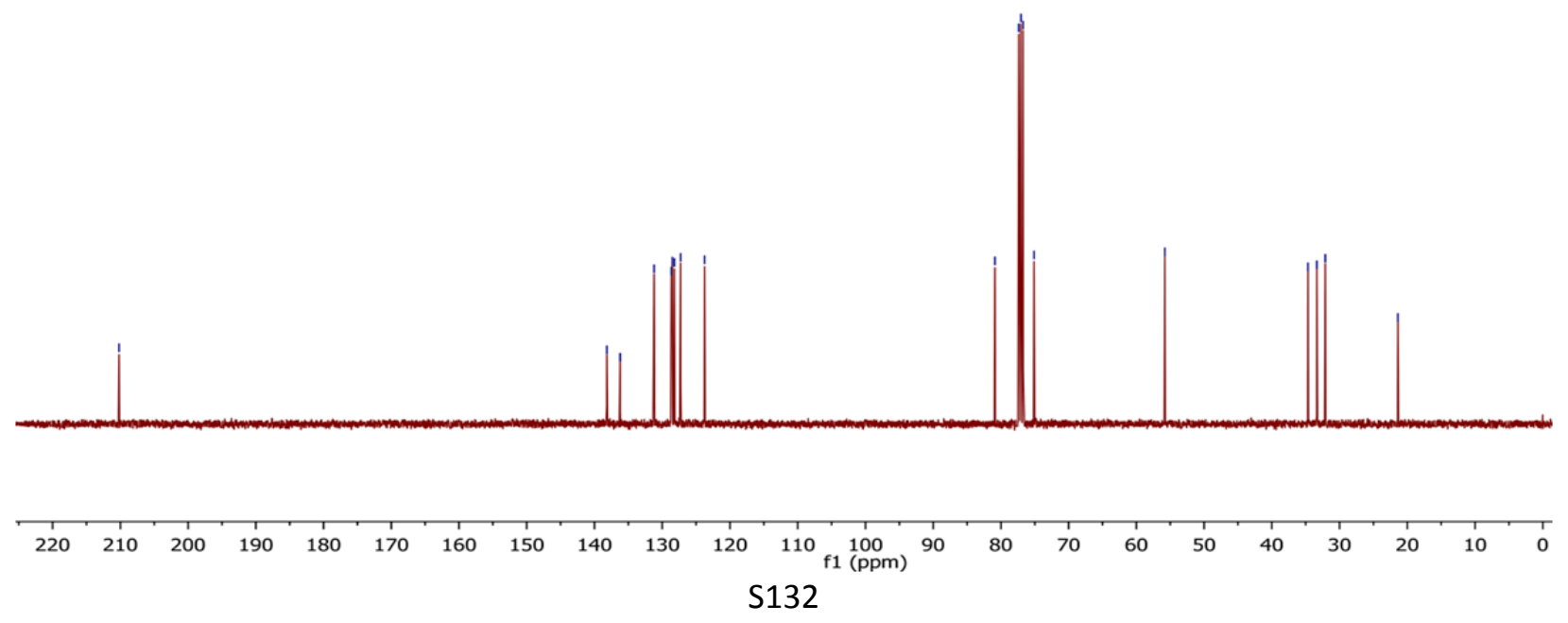



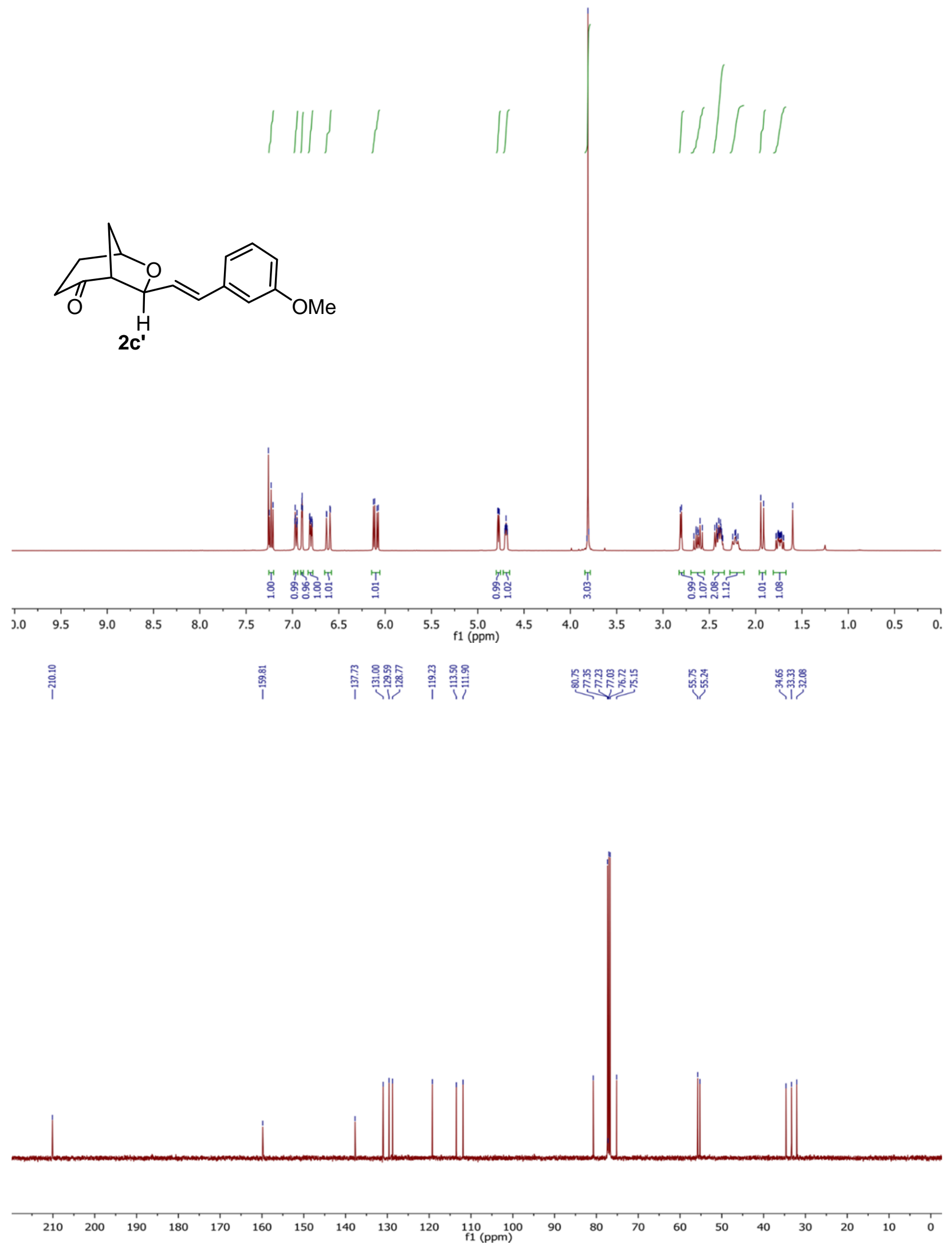


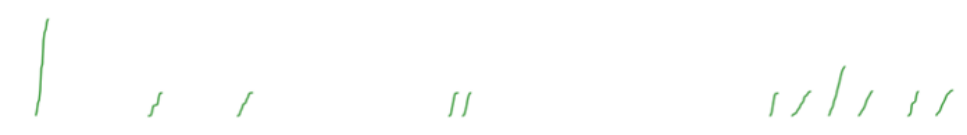<smiles>CC(C)(C)c1ccc(/C=C/[C@H]2O[C@H]3CC[C@H]2C(=O)C3)cc1</smiles>

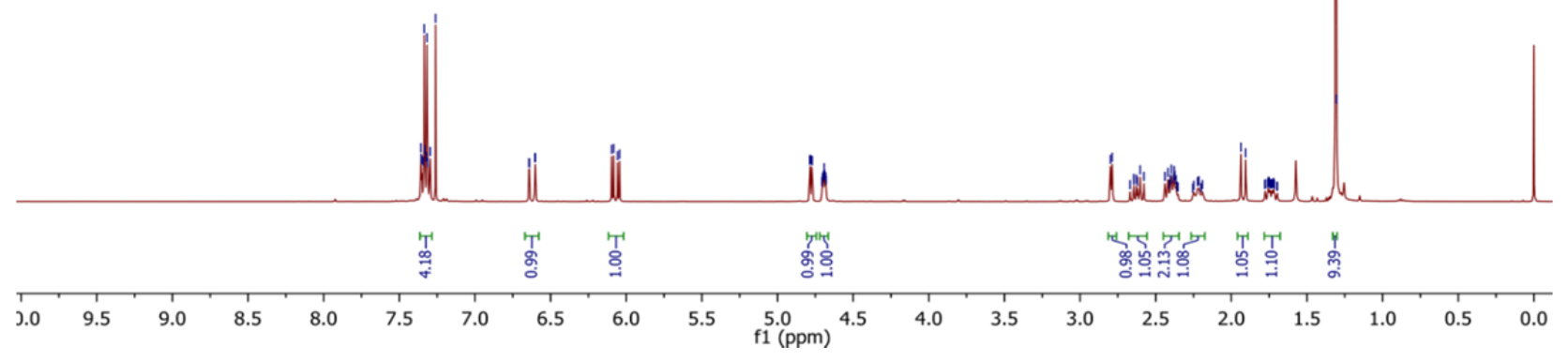
dong-pf২3-229-2-ac.10.fid
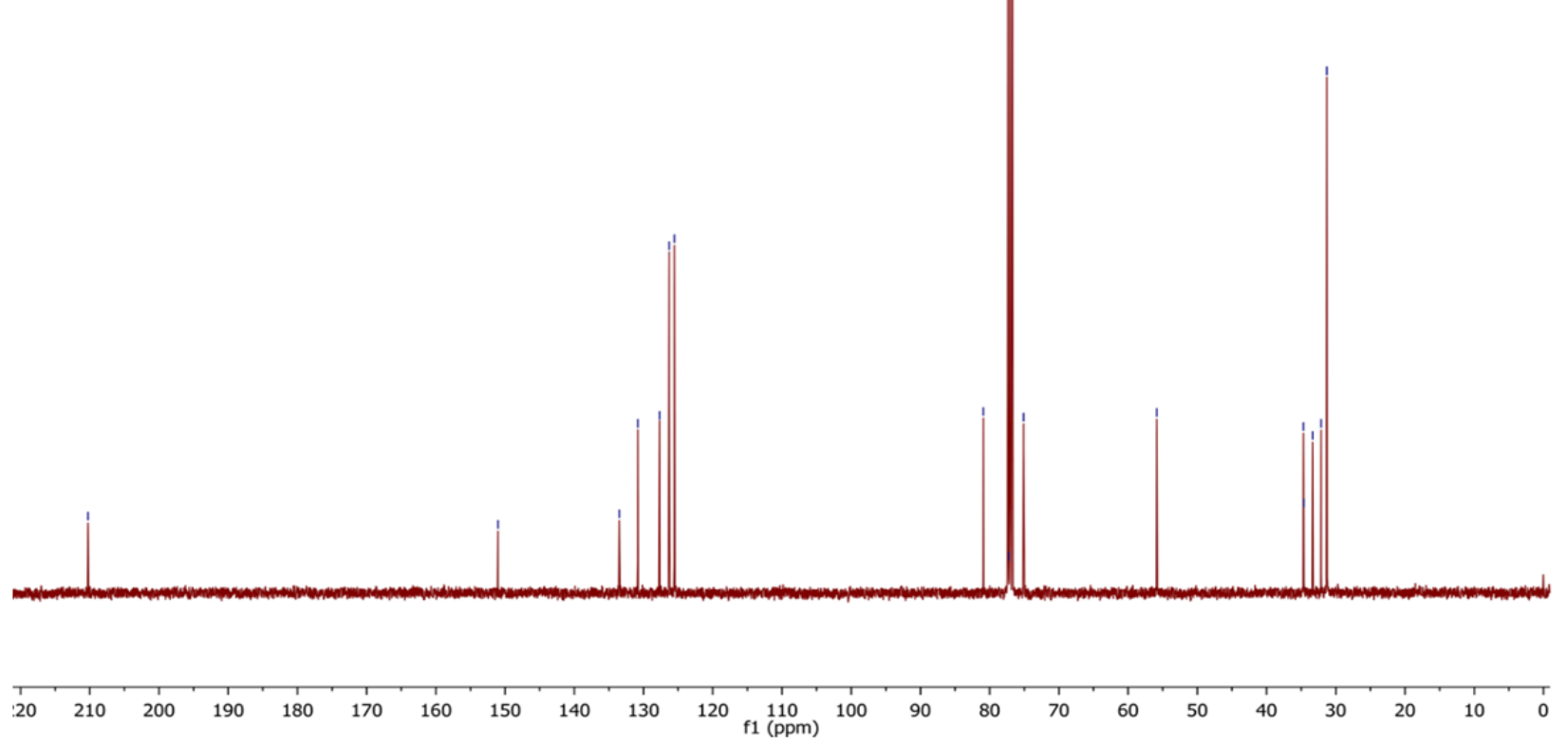


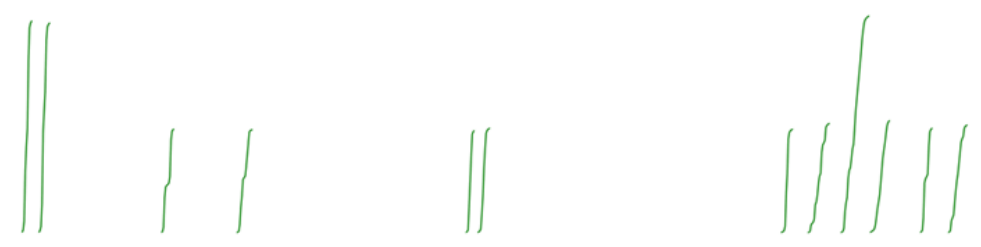<smiles>O[C@H]1[C@@H]2CC[C@@H]1C[C@@H](/C=C/c1ccc(C(F)(F)F)cc1)O2</smiles>
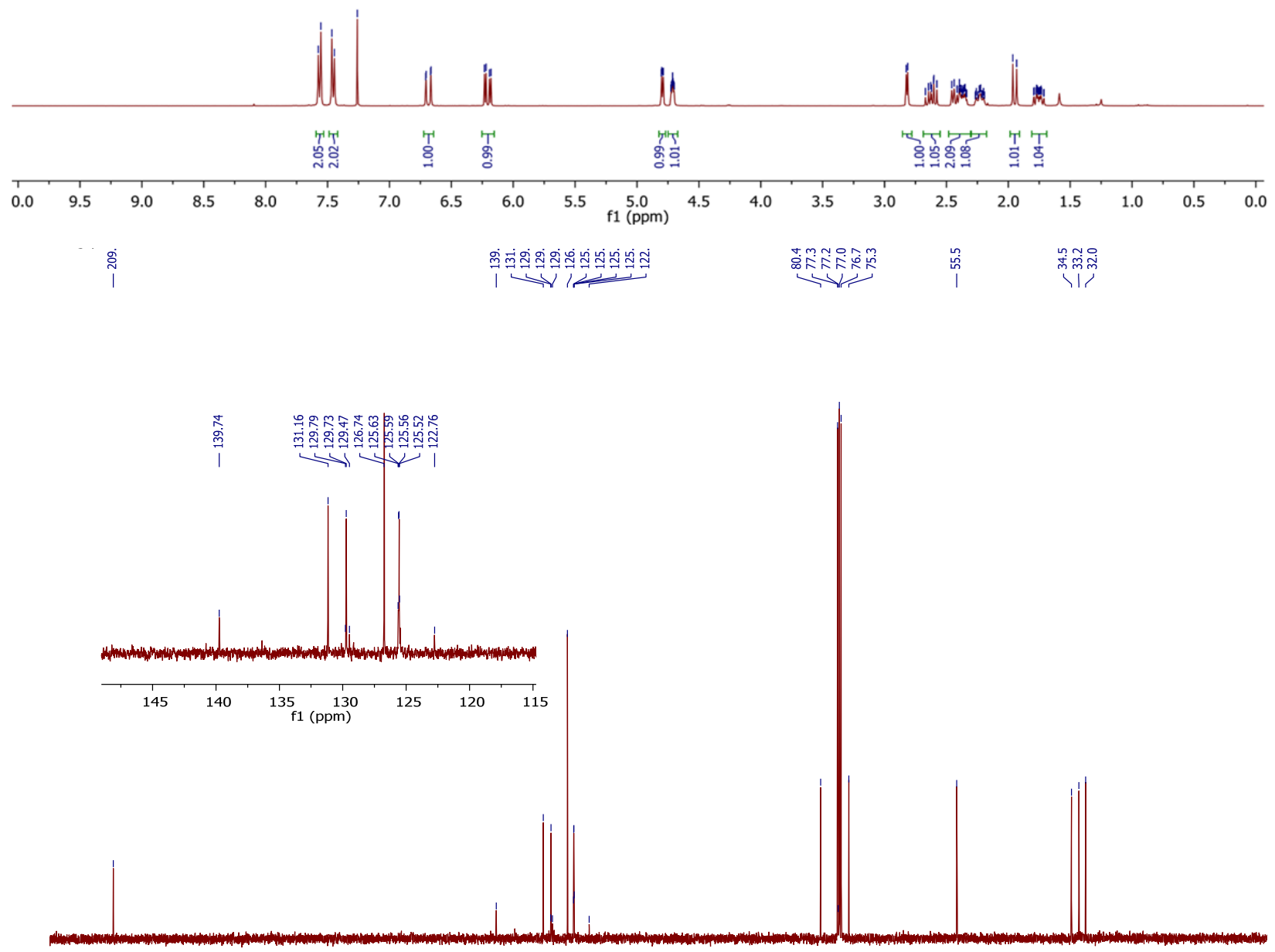

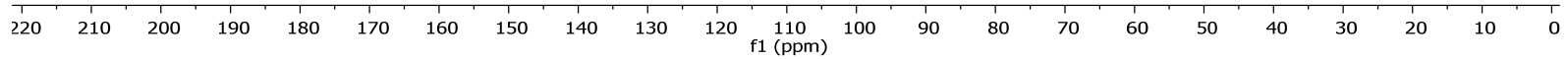




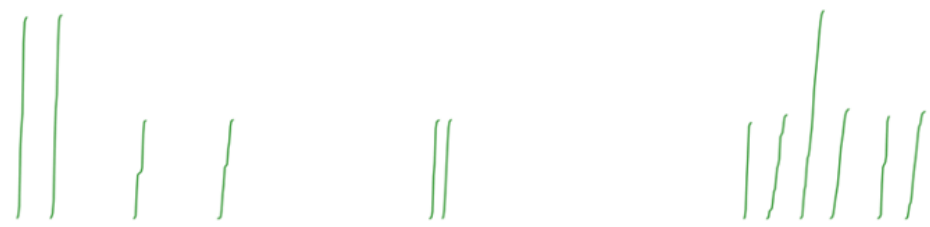<smiles>OC1CCC2CC1C(/C=C/c1ccc(OC(F)(F)F)cc1)O2</smiles>

2f'

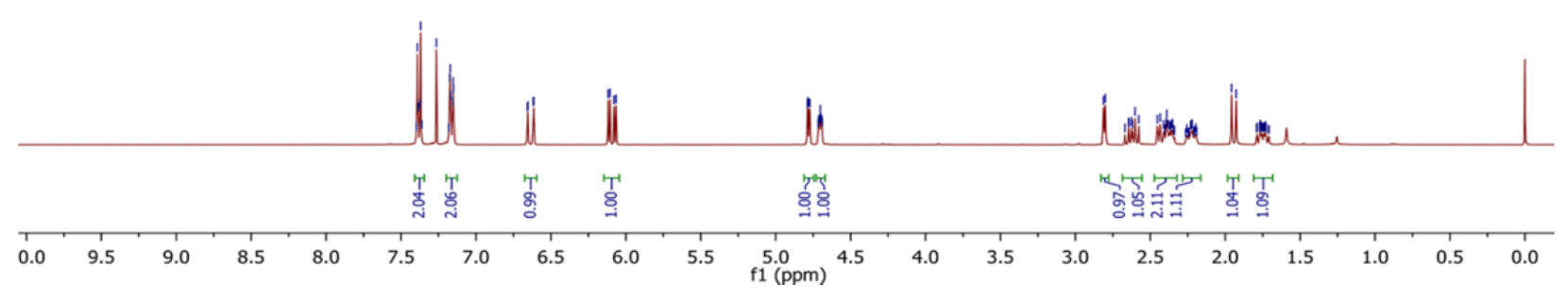

dong-p利2-229-4-acn.10.fid

กั่

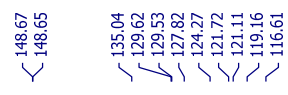

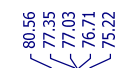

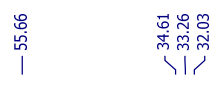

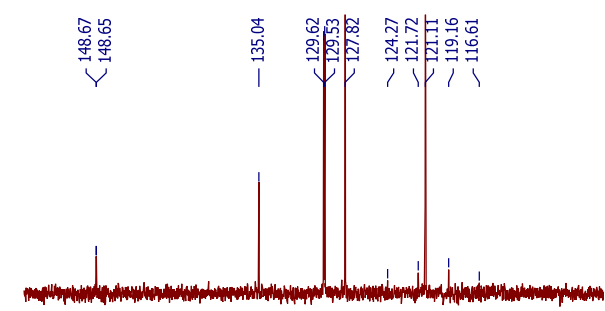

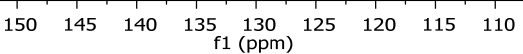
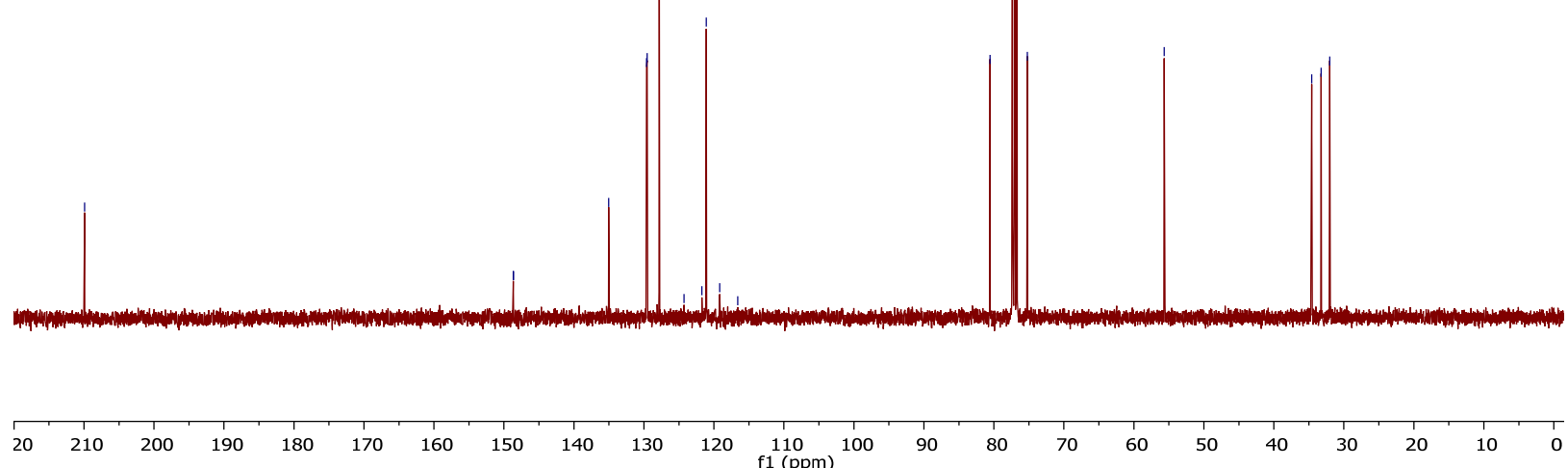


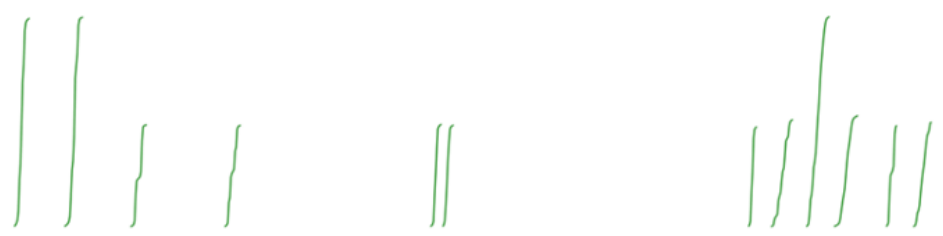

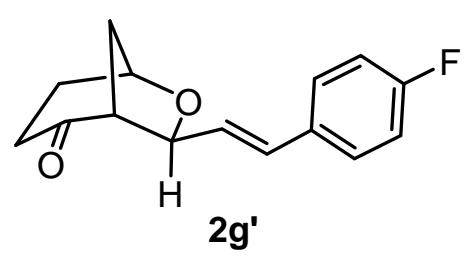

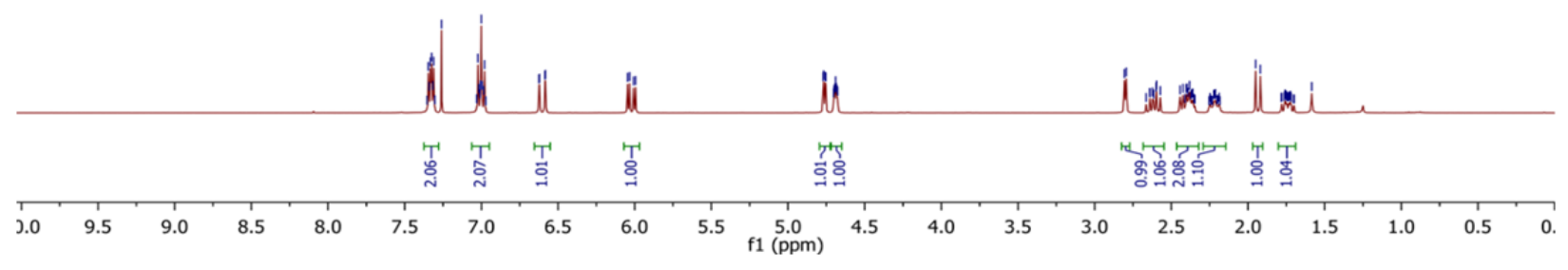
dong-pfes-201-2-nn.10.fid i †ำ

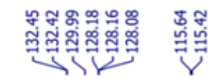

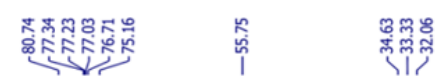
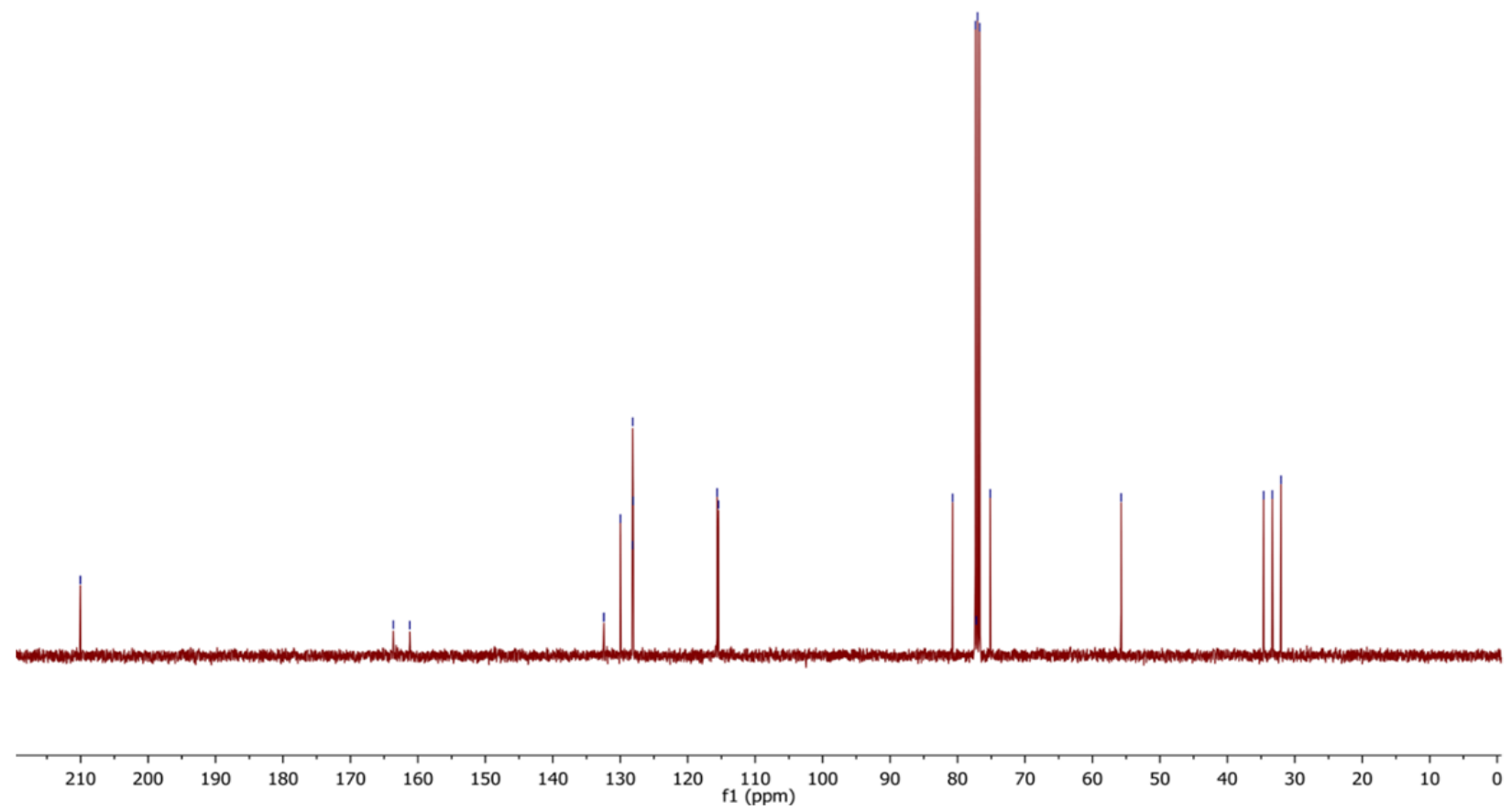


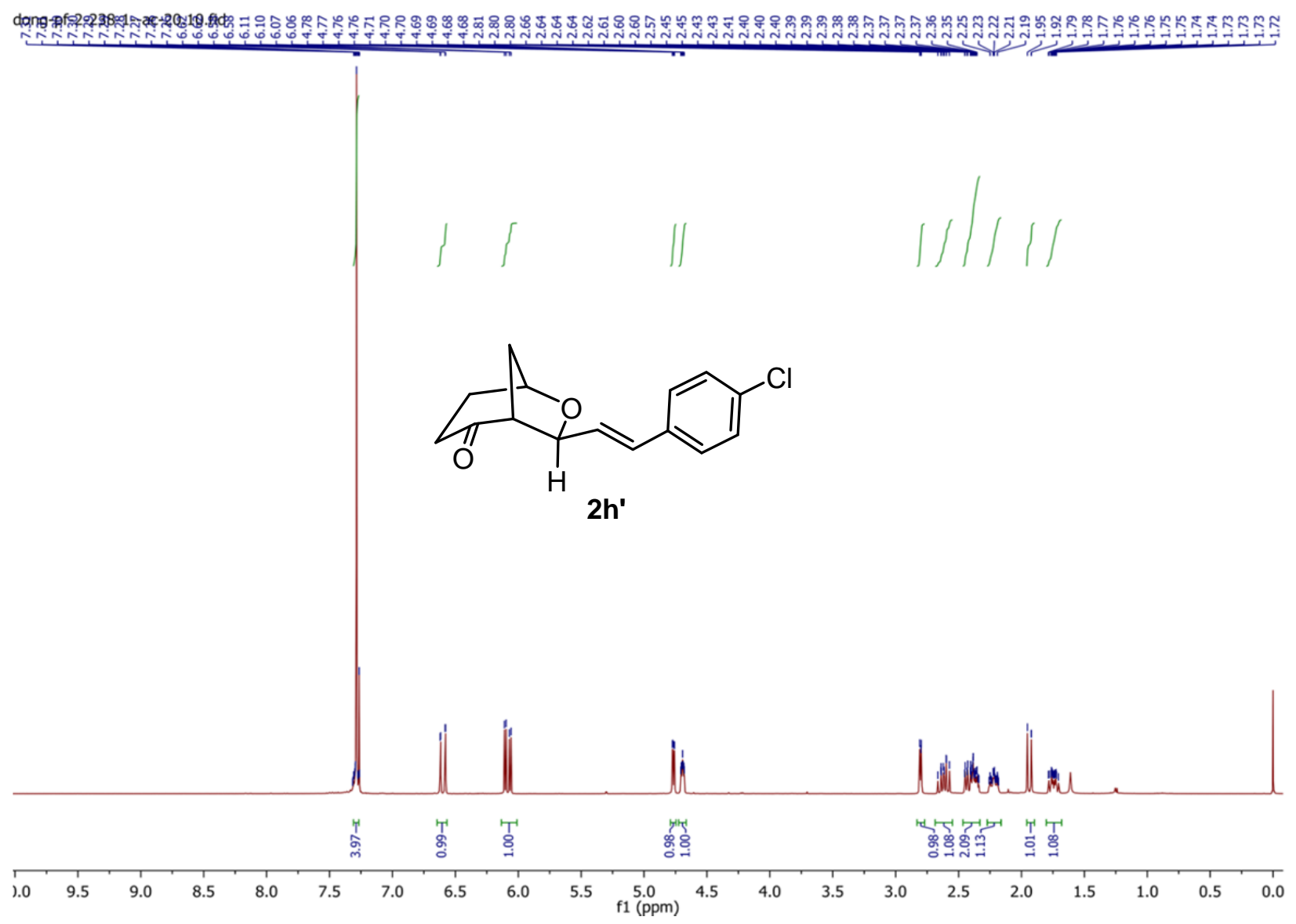

dong-pf-gr-238-1-nn.10.fid

i

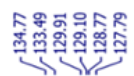
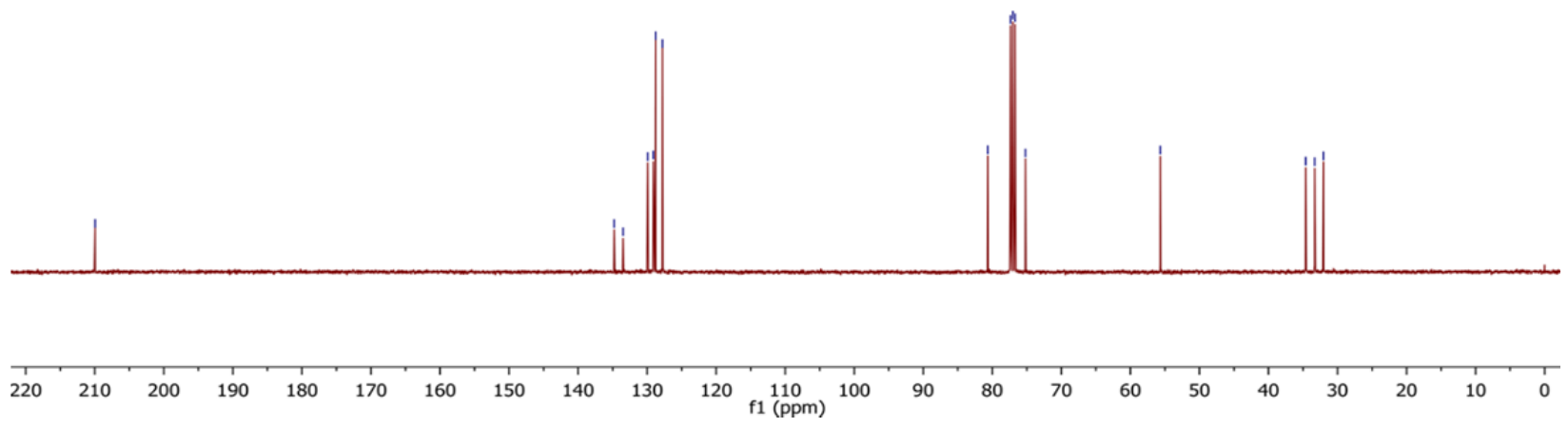


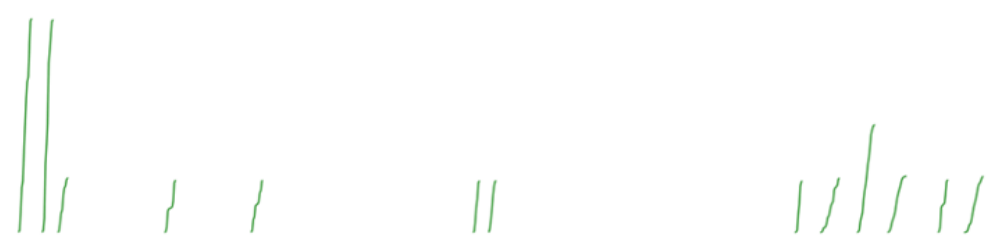<smiles>[Te]C/C=C/c1ccc(-c2ccccc2)cc1</smiles>

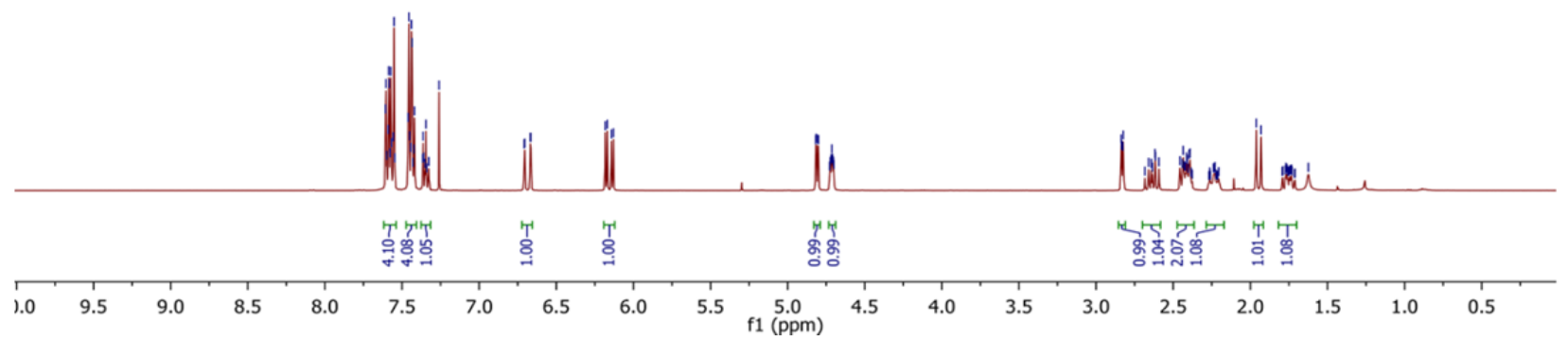
dong-pfo2-231-3-ac-n.20.fid กิ

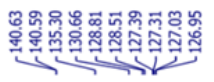

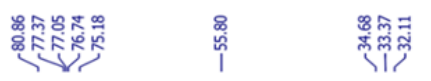
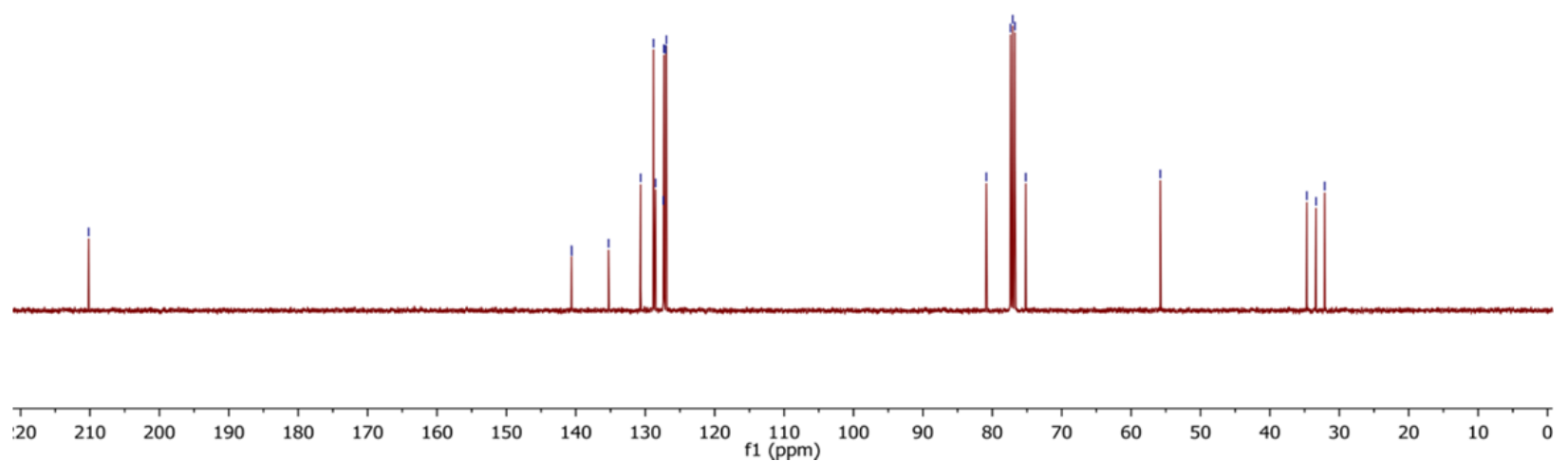


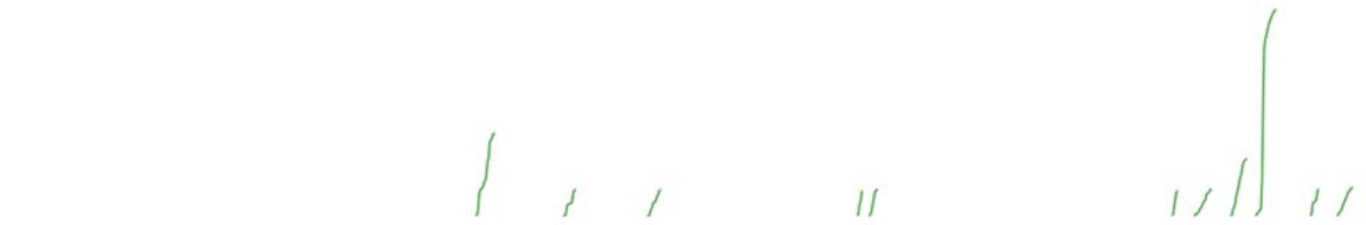<smiles>Cc1ccc(/C=C/C2OC3CCC(CC3)C2CO)cc1C</smiles>

2j'

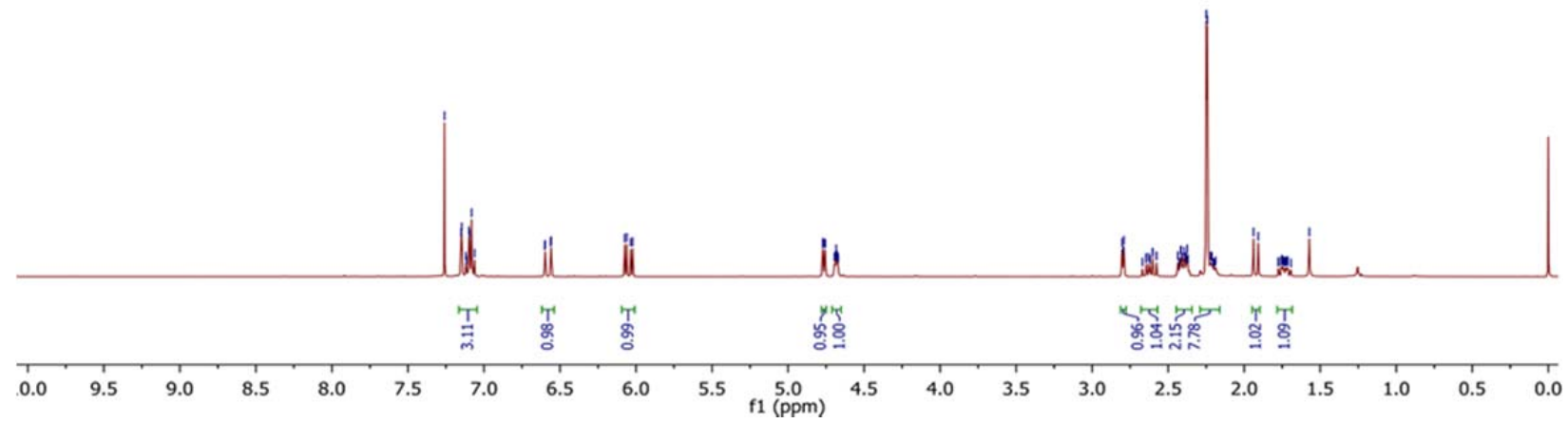

dong-pf-2శ్శ29-3-acn.10.fid
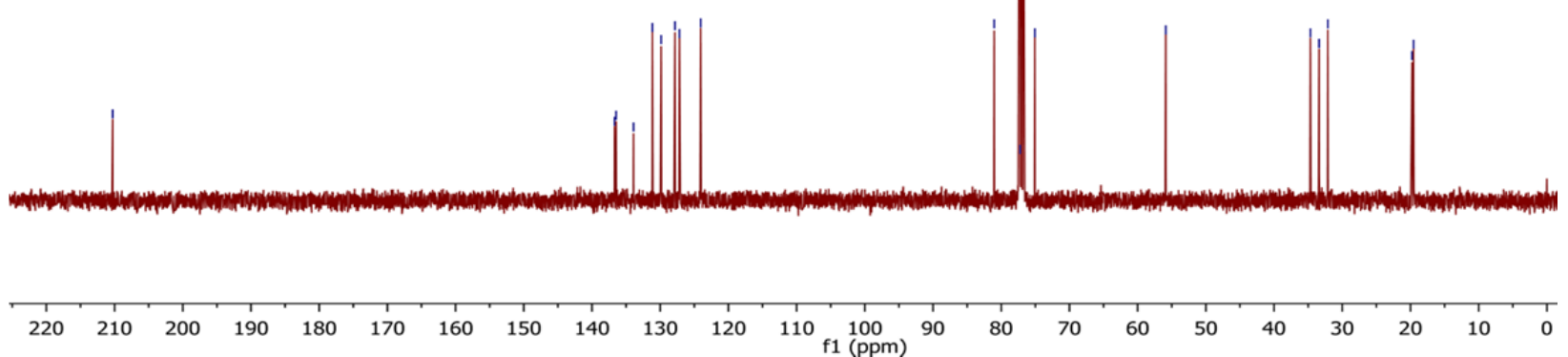

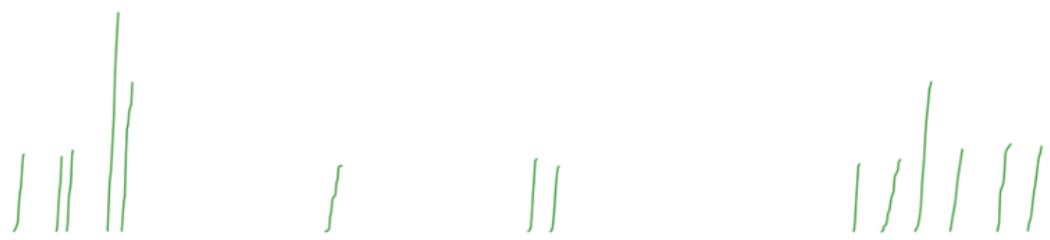<smiles>OCC1C2CC=CC(C2)OC1/C=C/c1cccc2ccccc12</smiles>

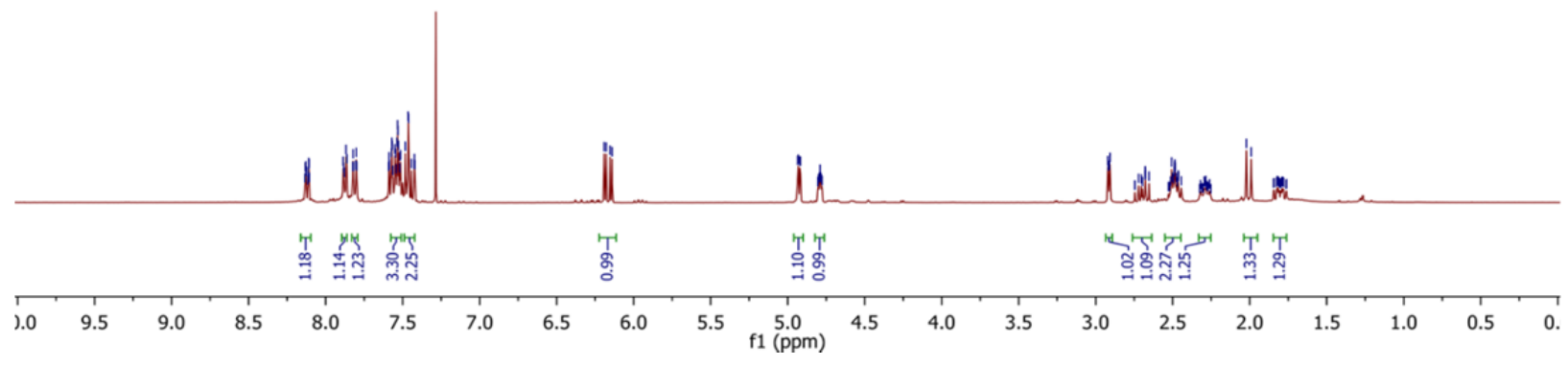

至
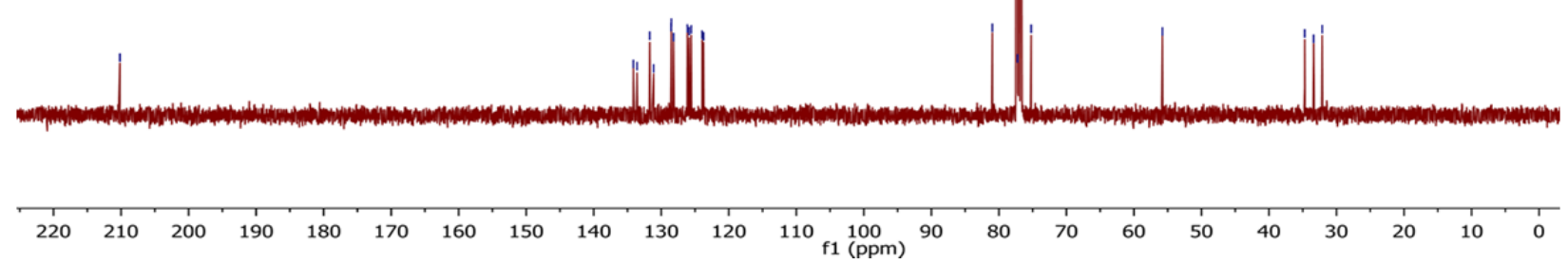

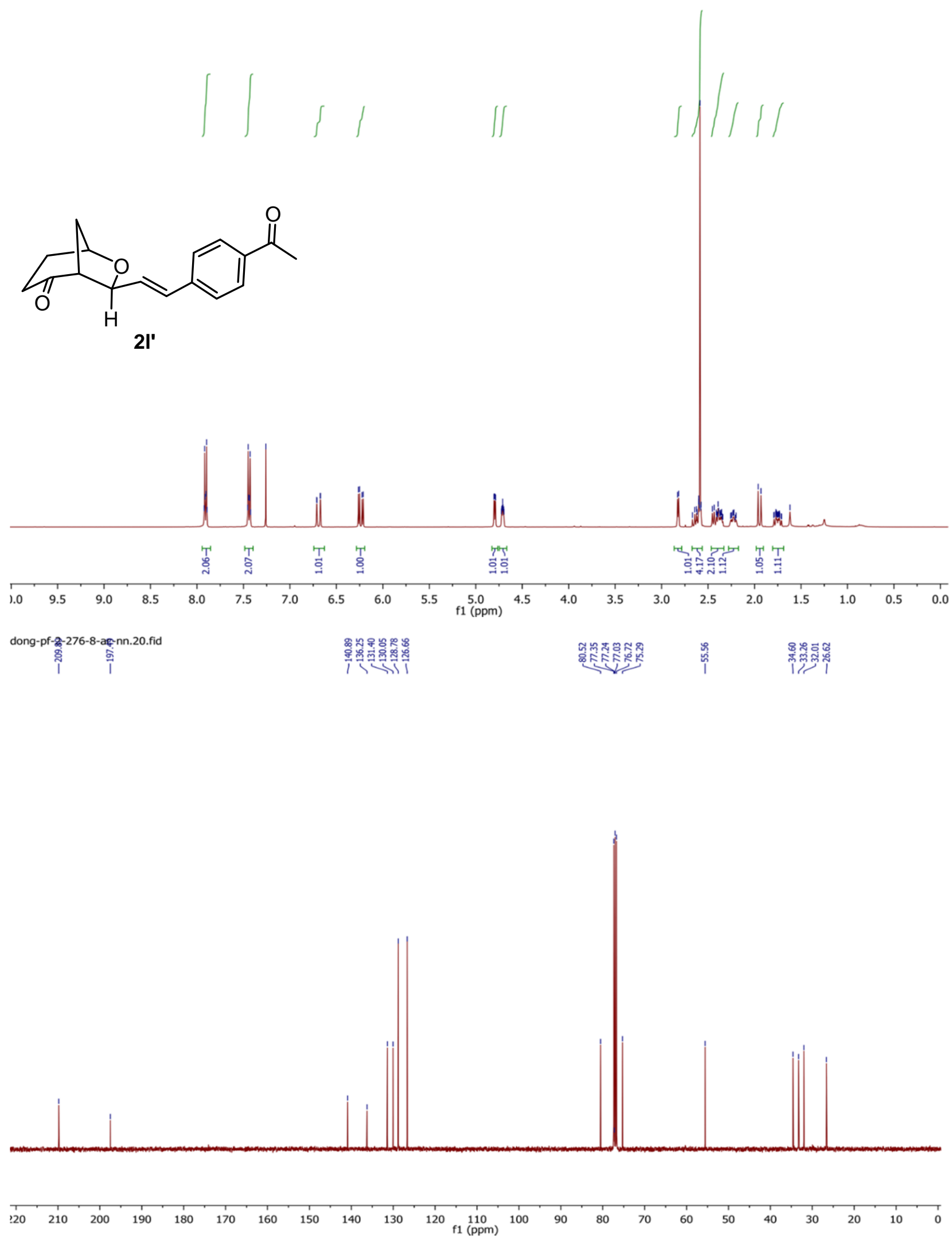

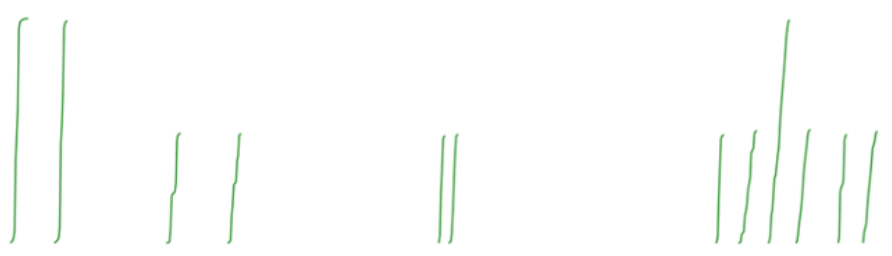<smiles>O=Cc1ccc(/C=C/C2OC3CCCC2C3)cc1</smiles>

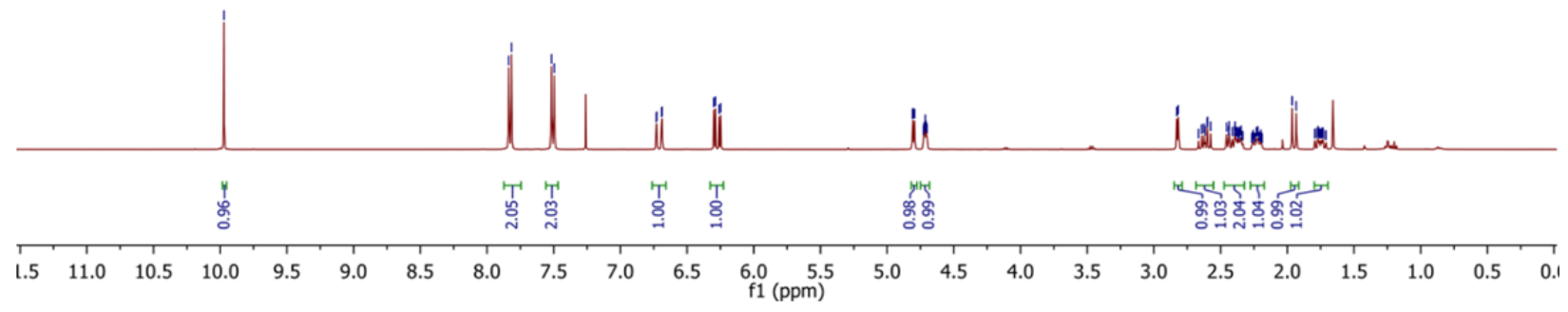

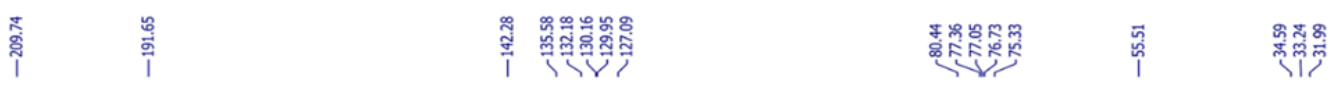

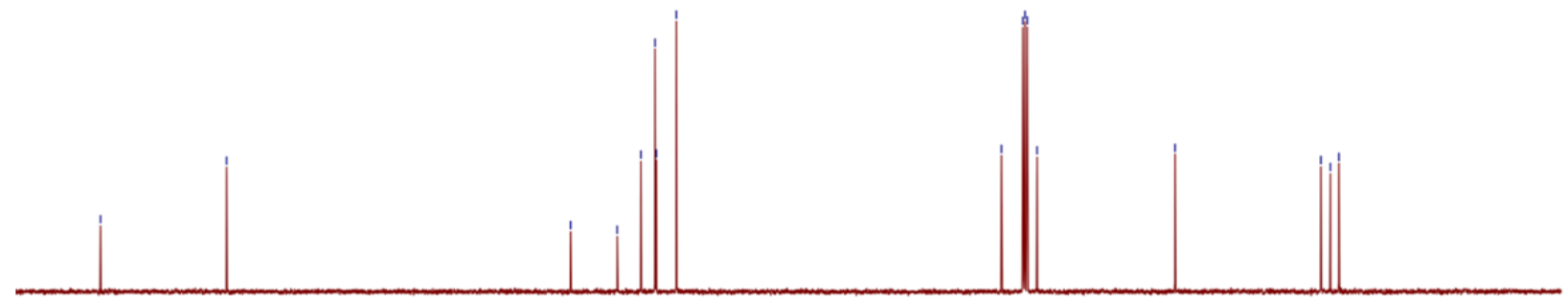

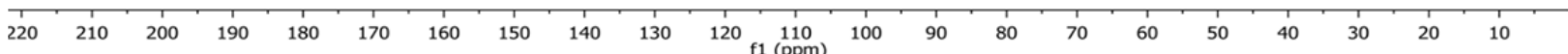
S143 

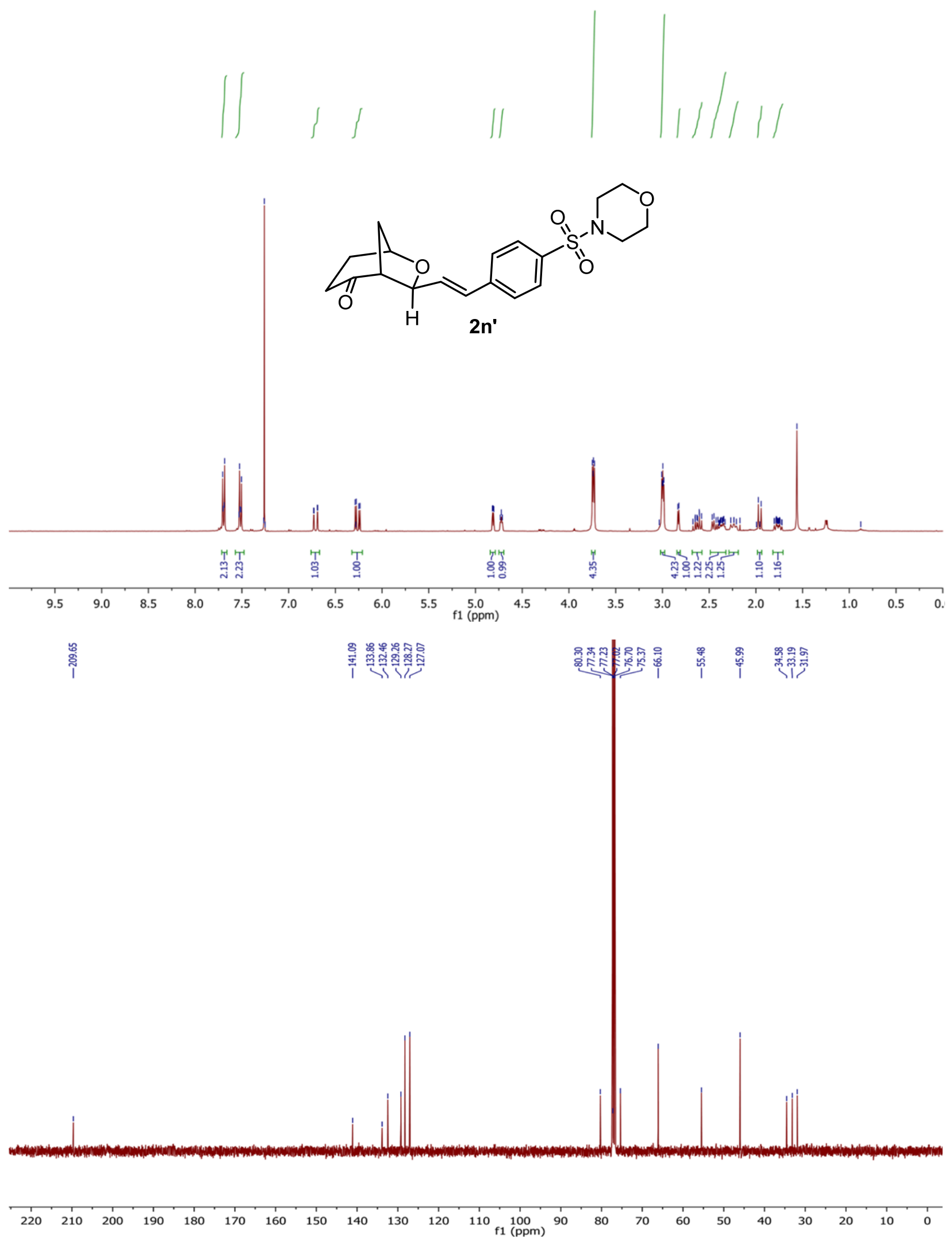

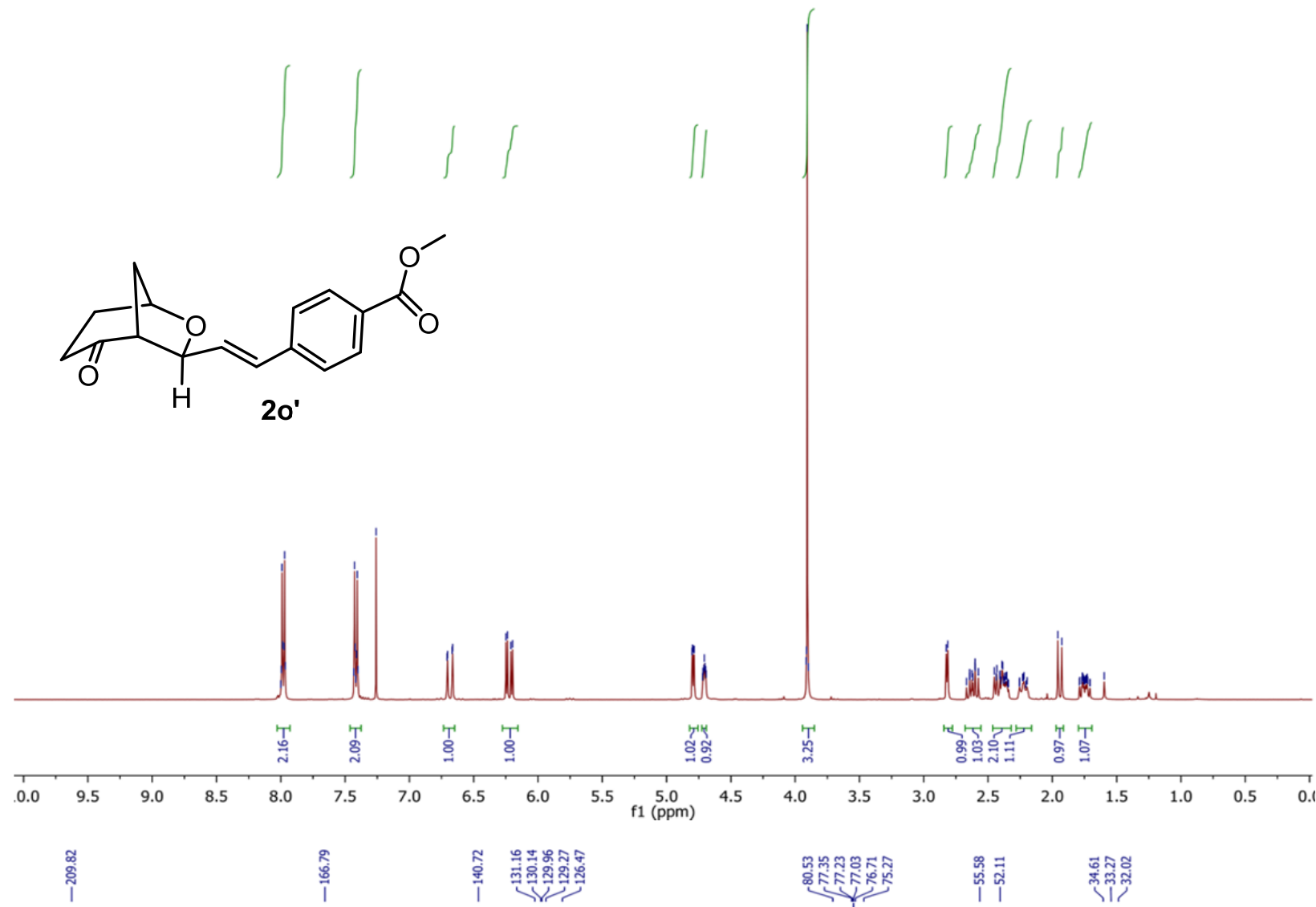

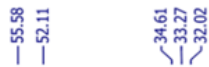
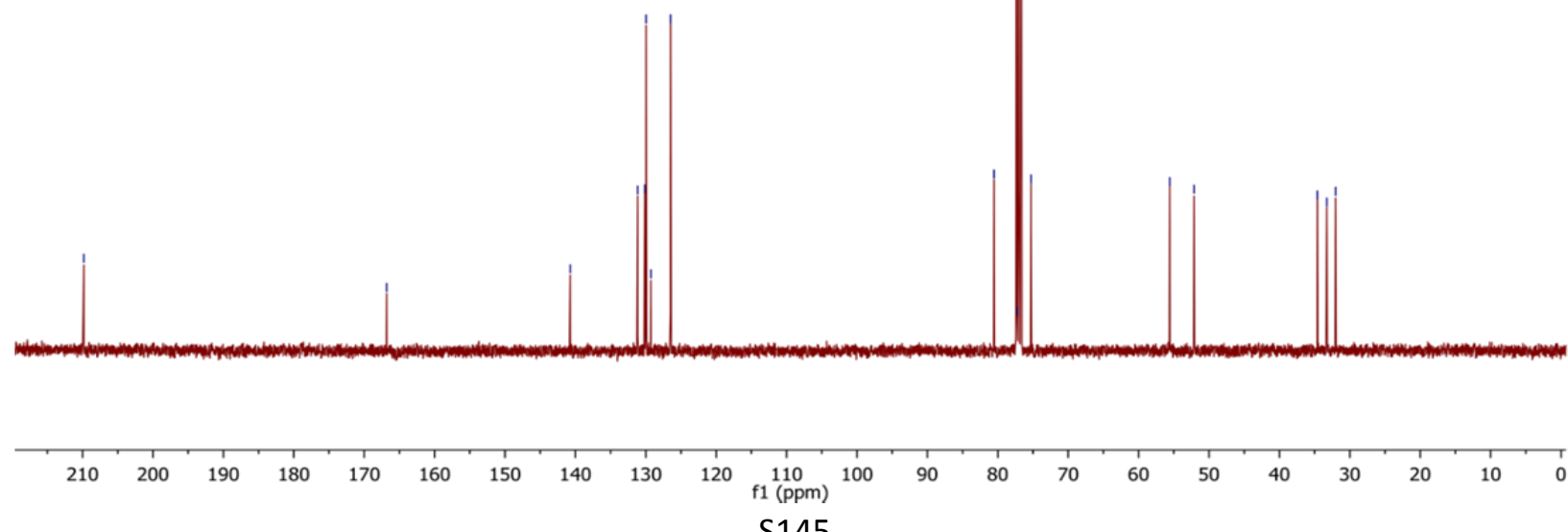

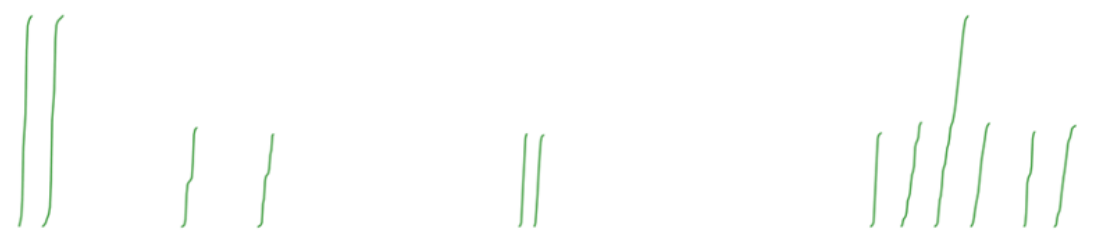<smiles>N#Cc1ccc(/C=C/[C@@H]2C[C@@H]3CC[C@H](O2)[C@@H]3O)cc1</smiles>
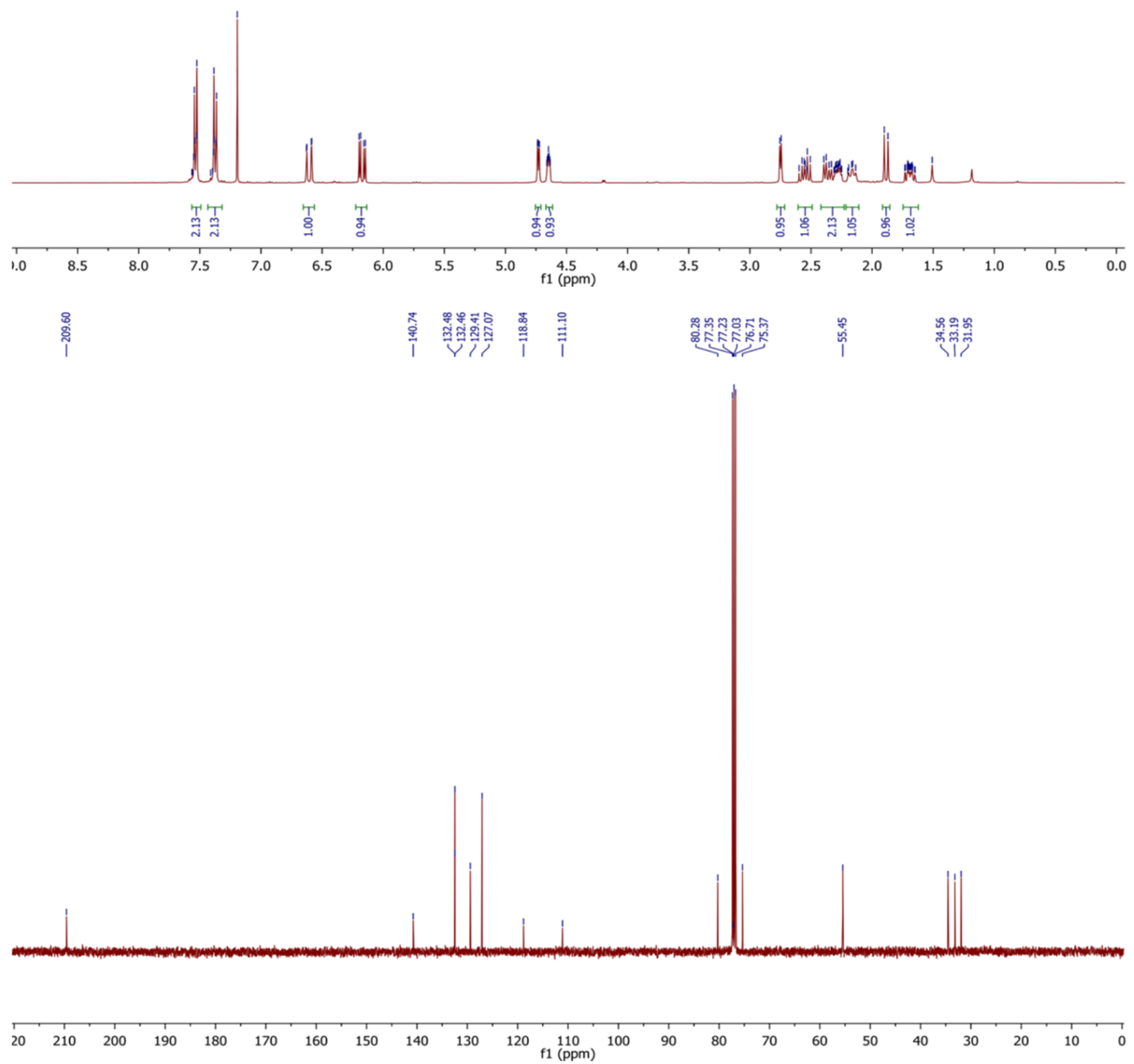
S146 

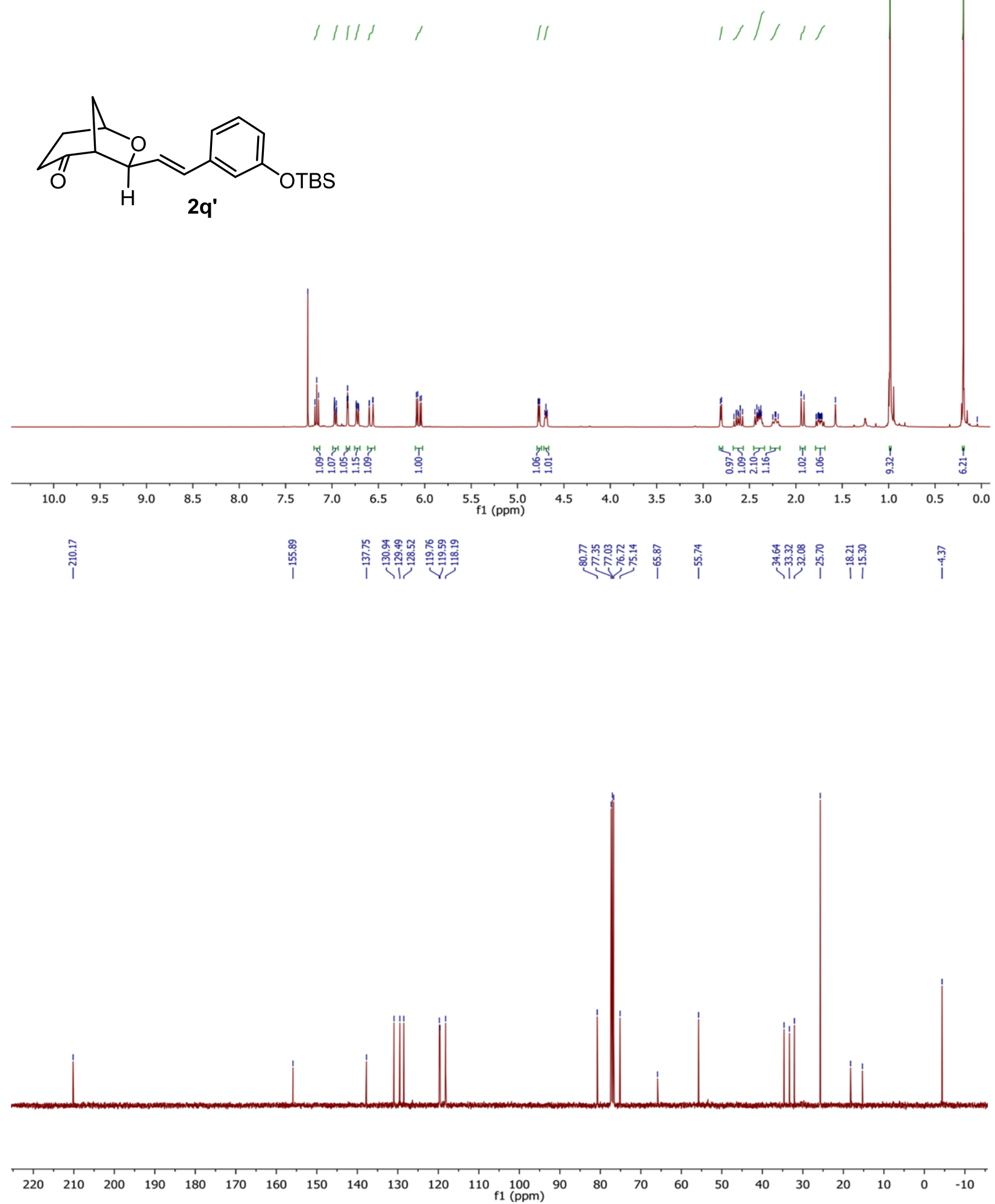
S147 

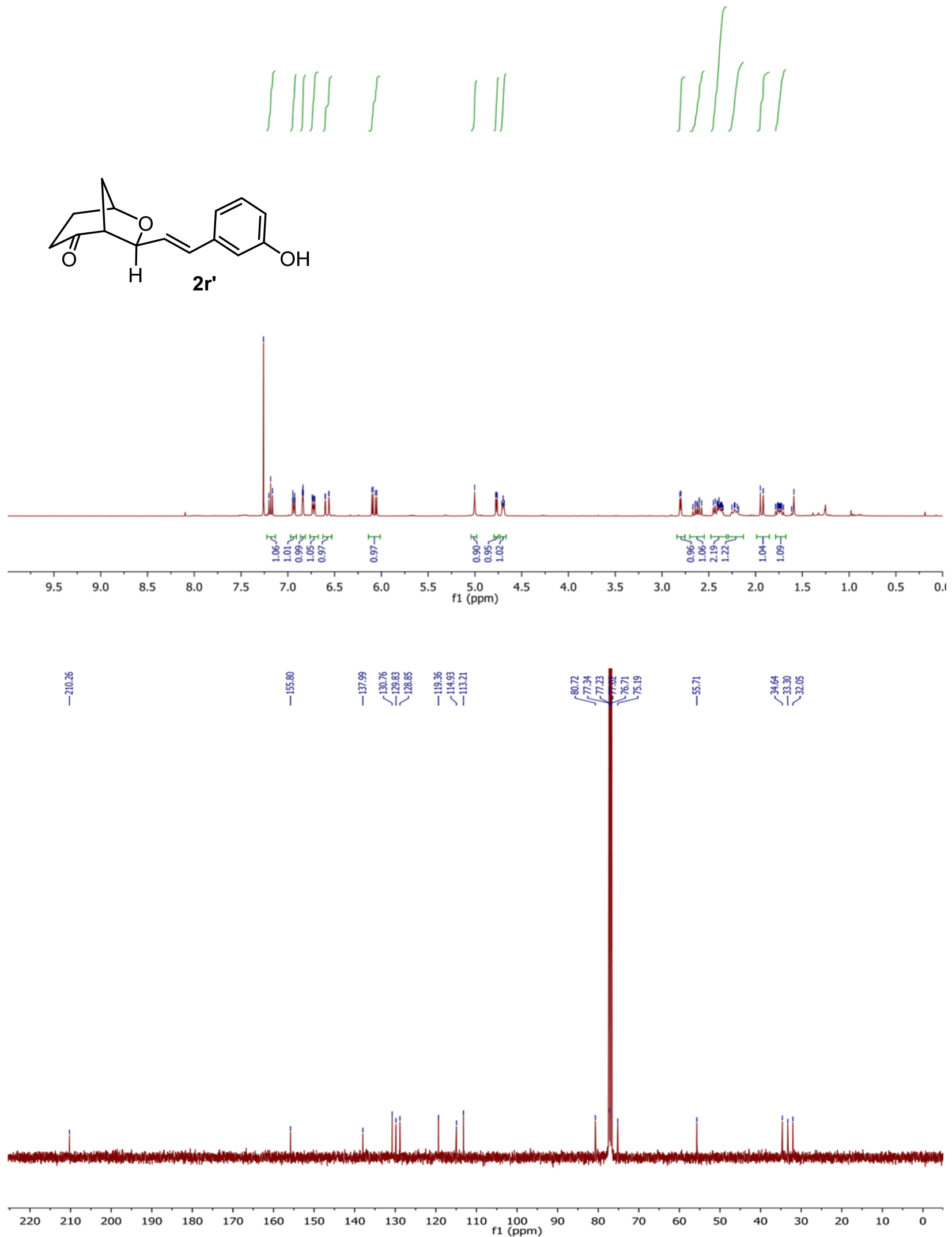


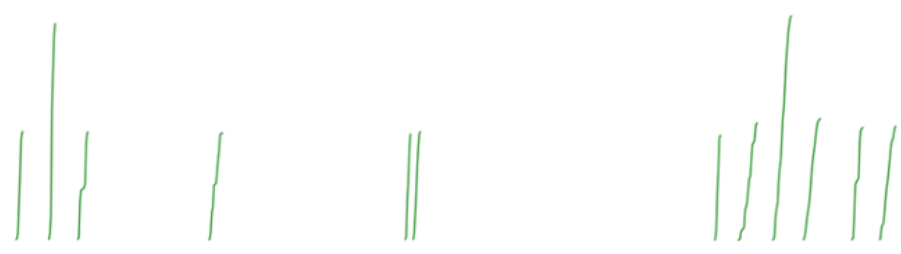<smiles>C1=CC2CC(C1)OC2C=Cc1cccs1</smiles>

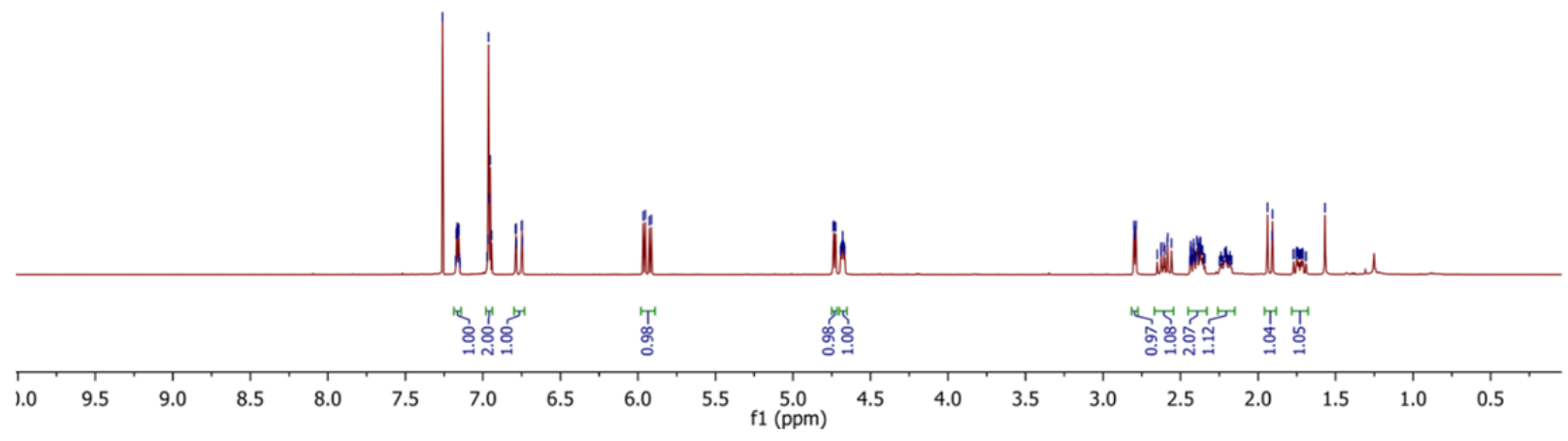

竞
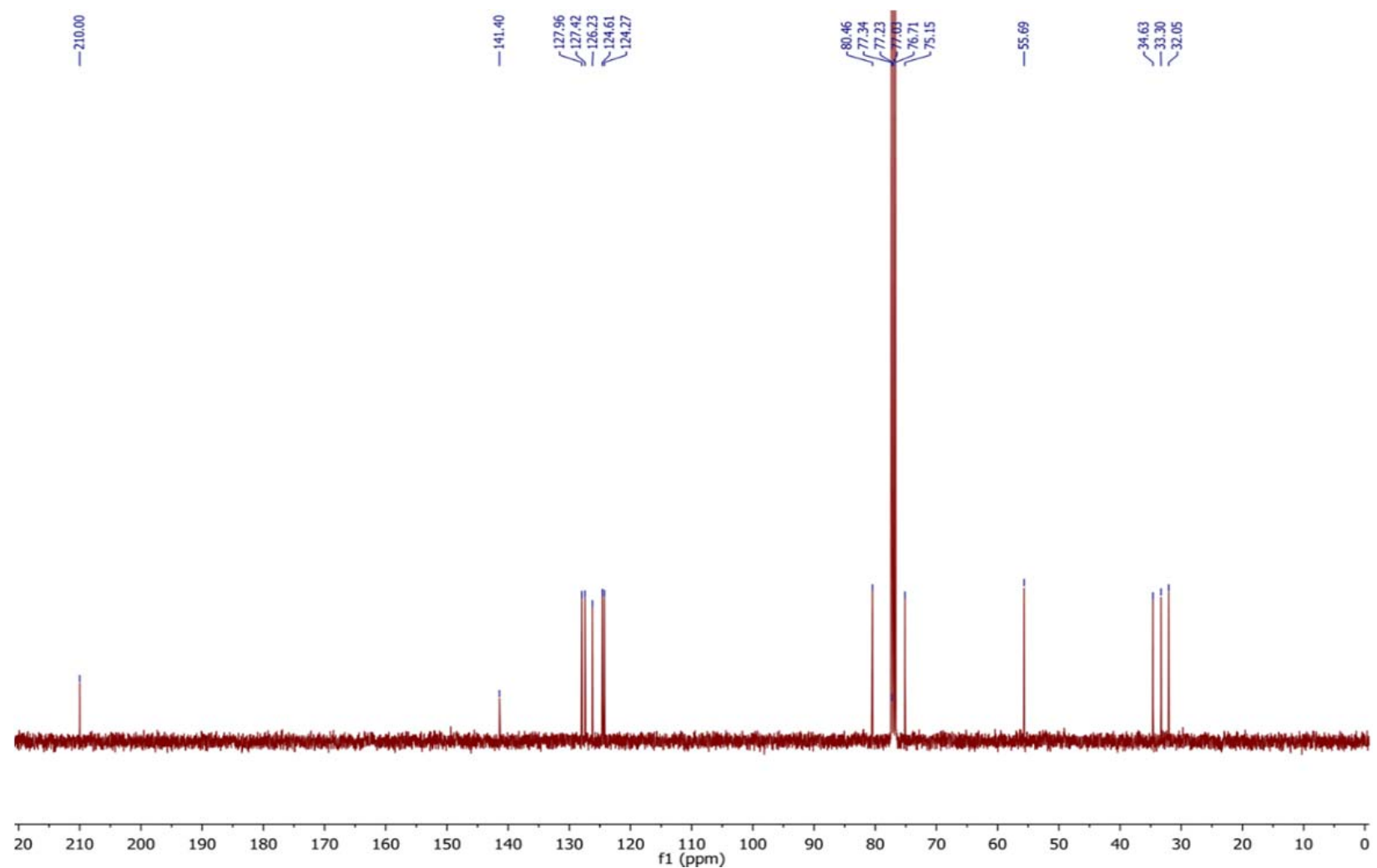

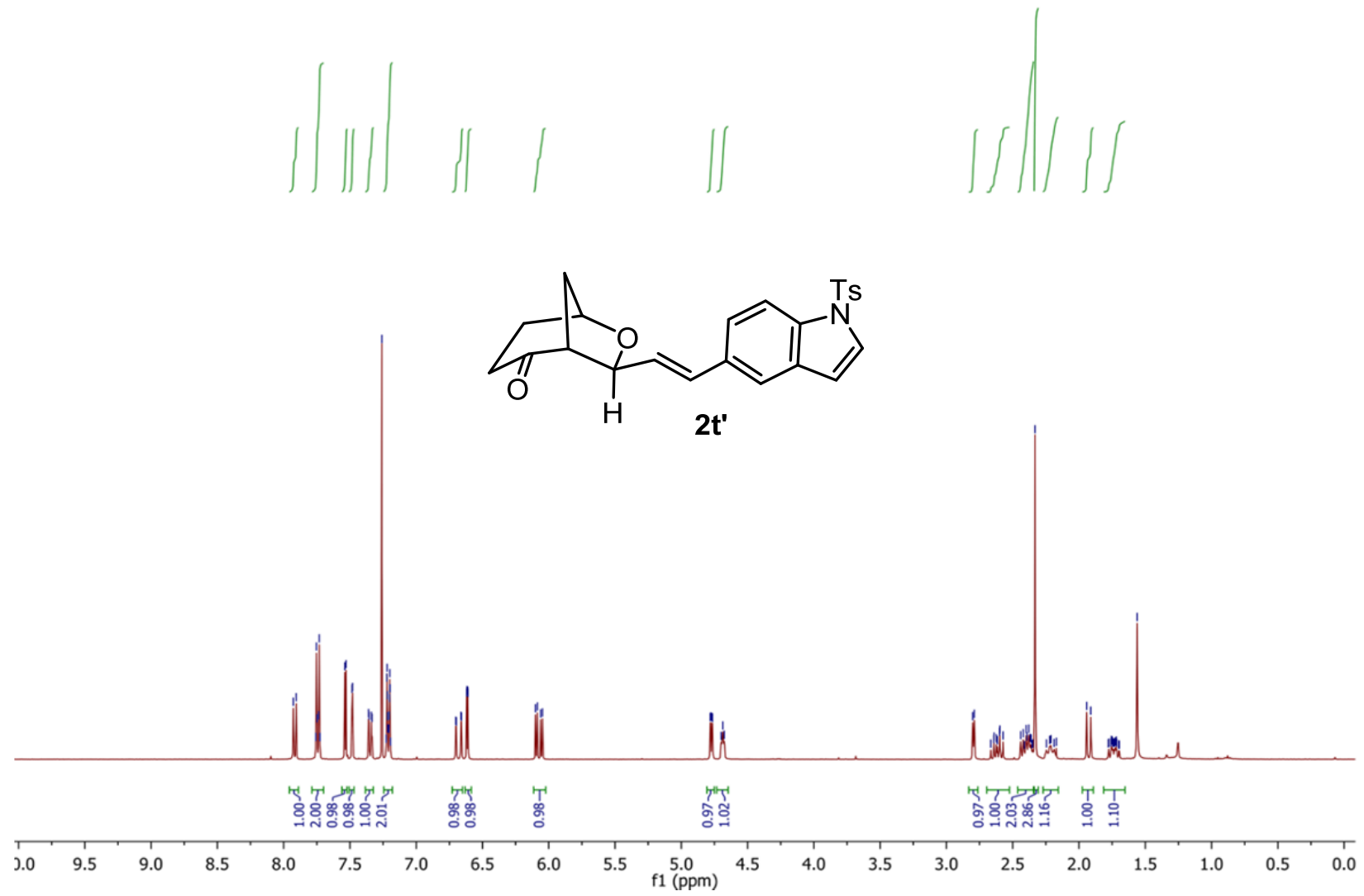
i

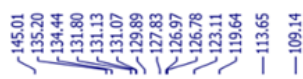
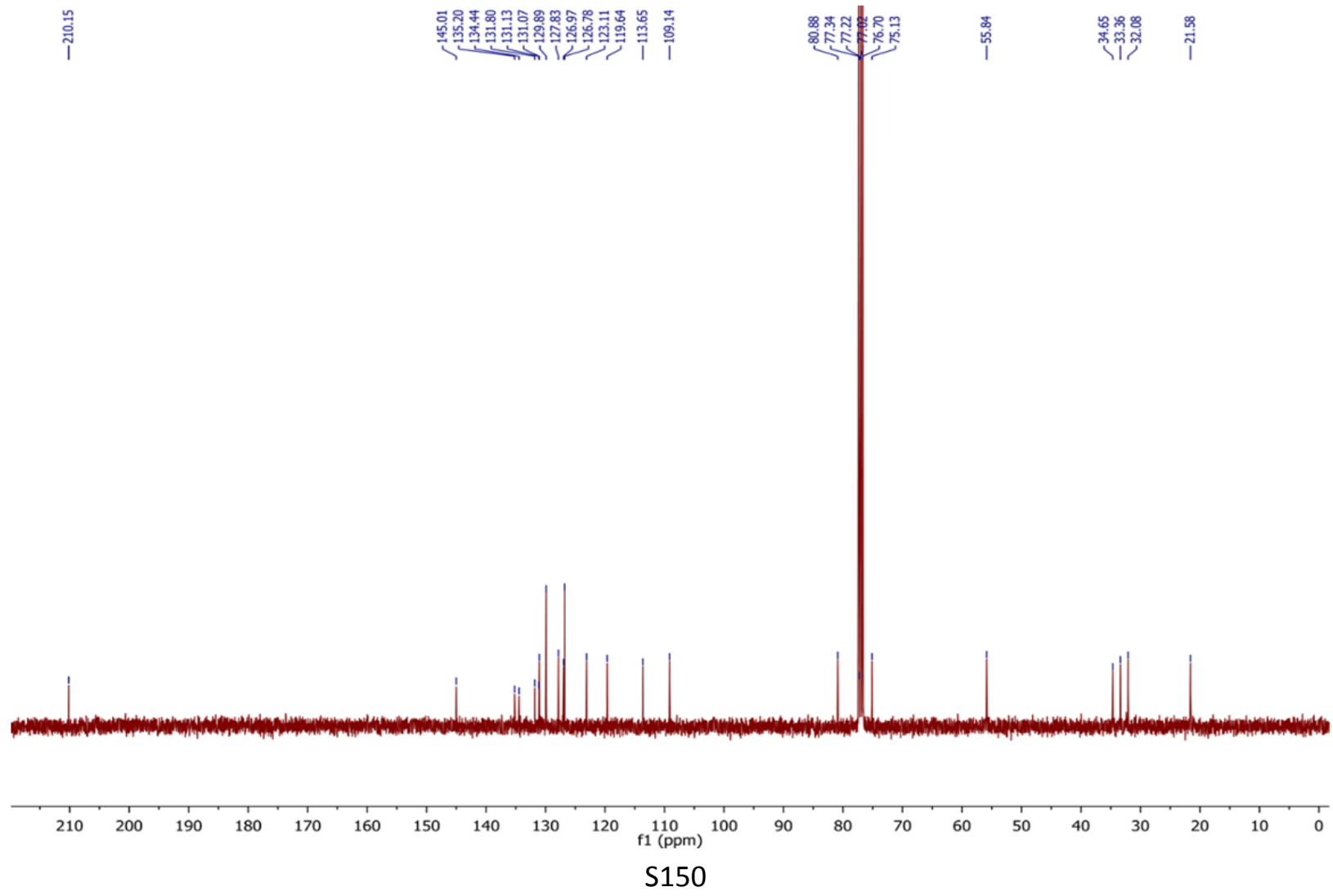


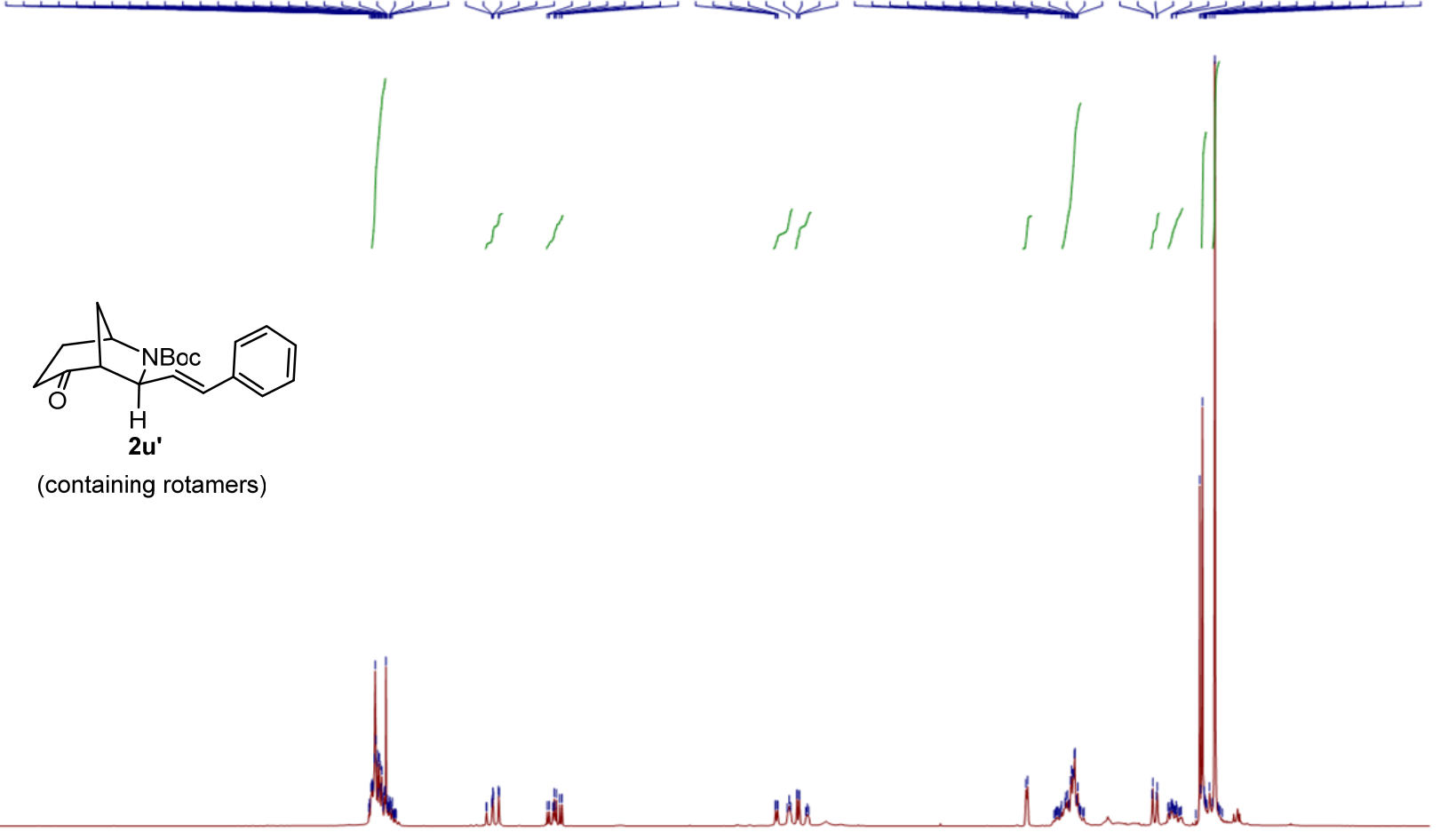

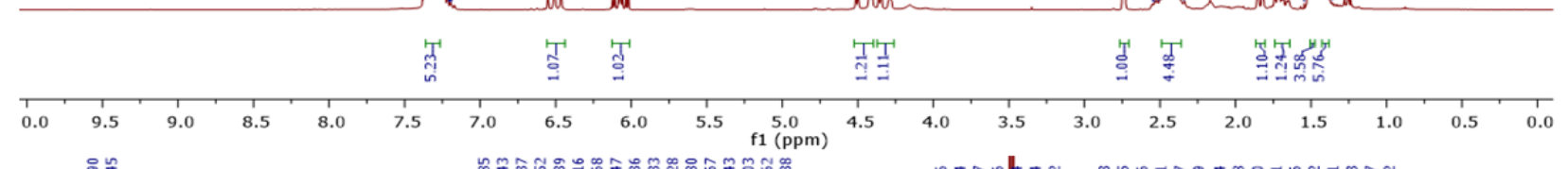
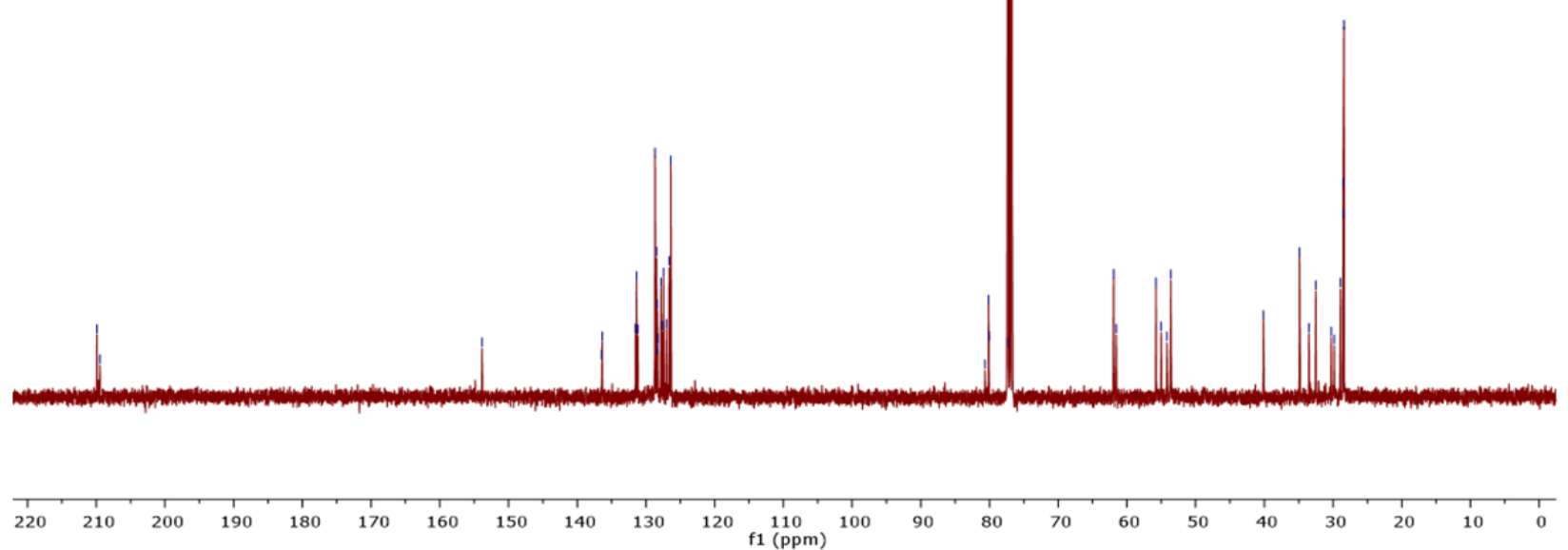

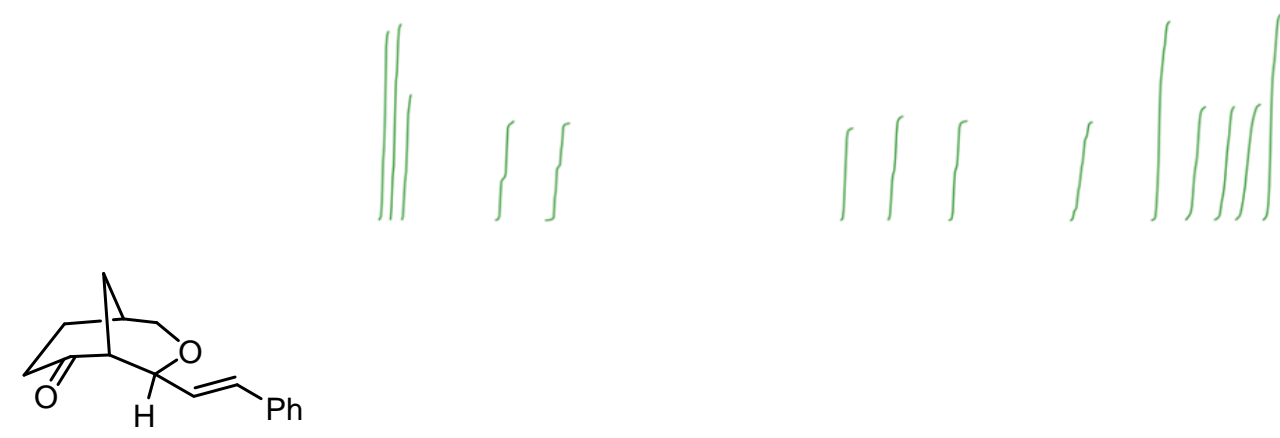

2v'
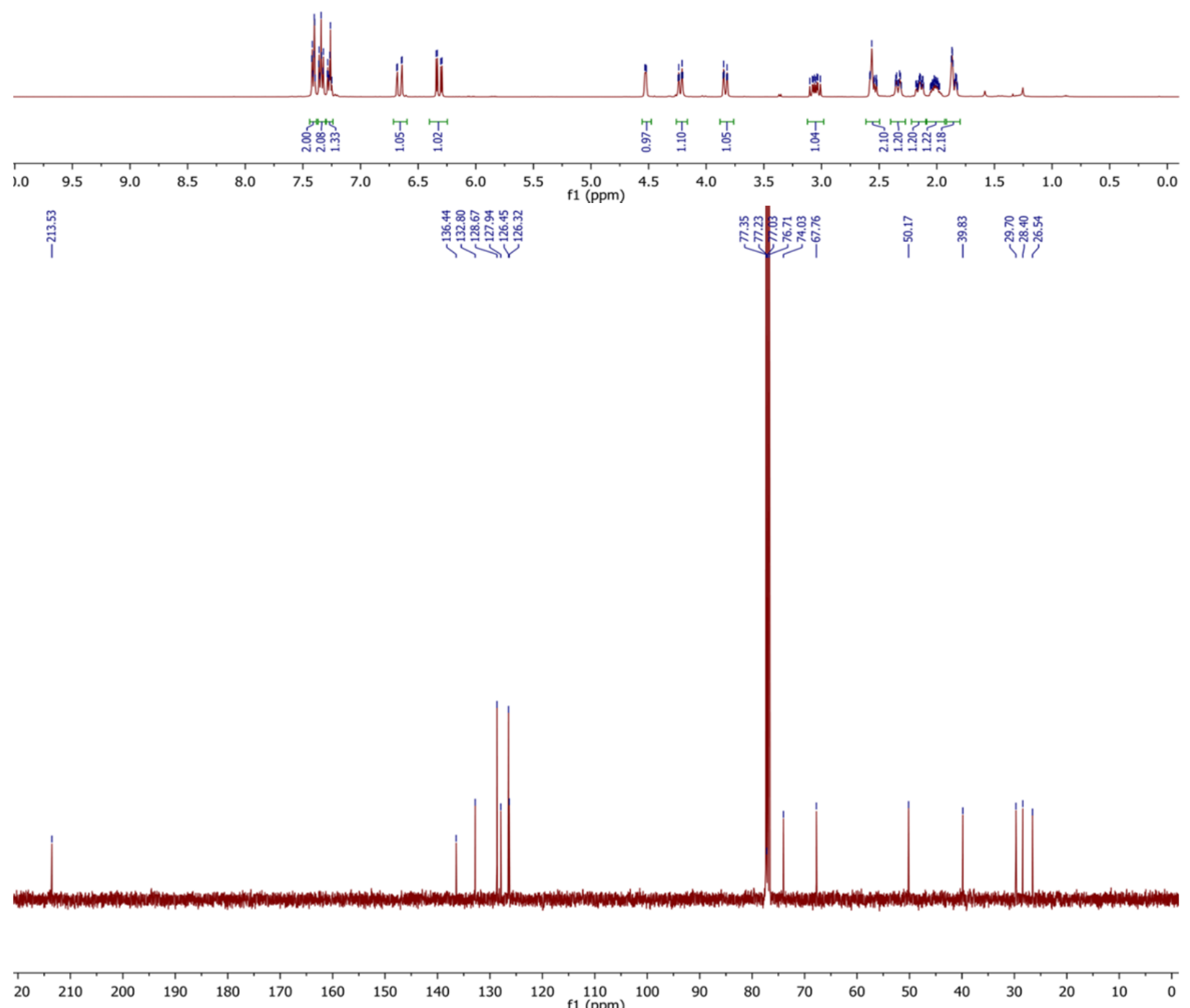

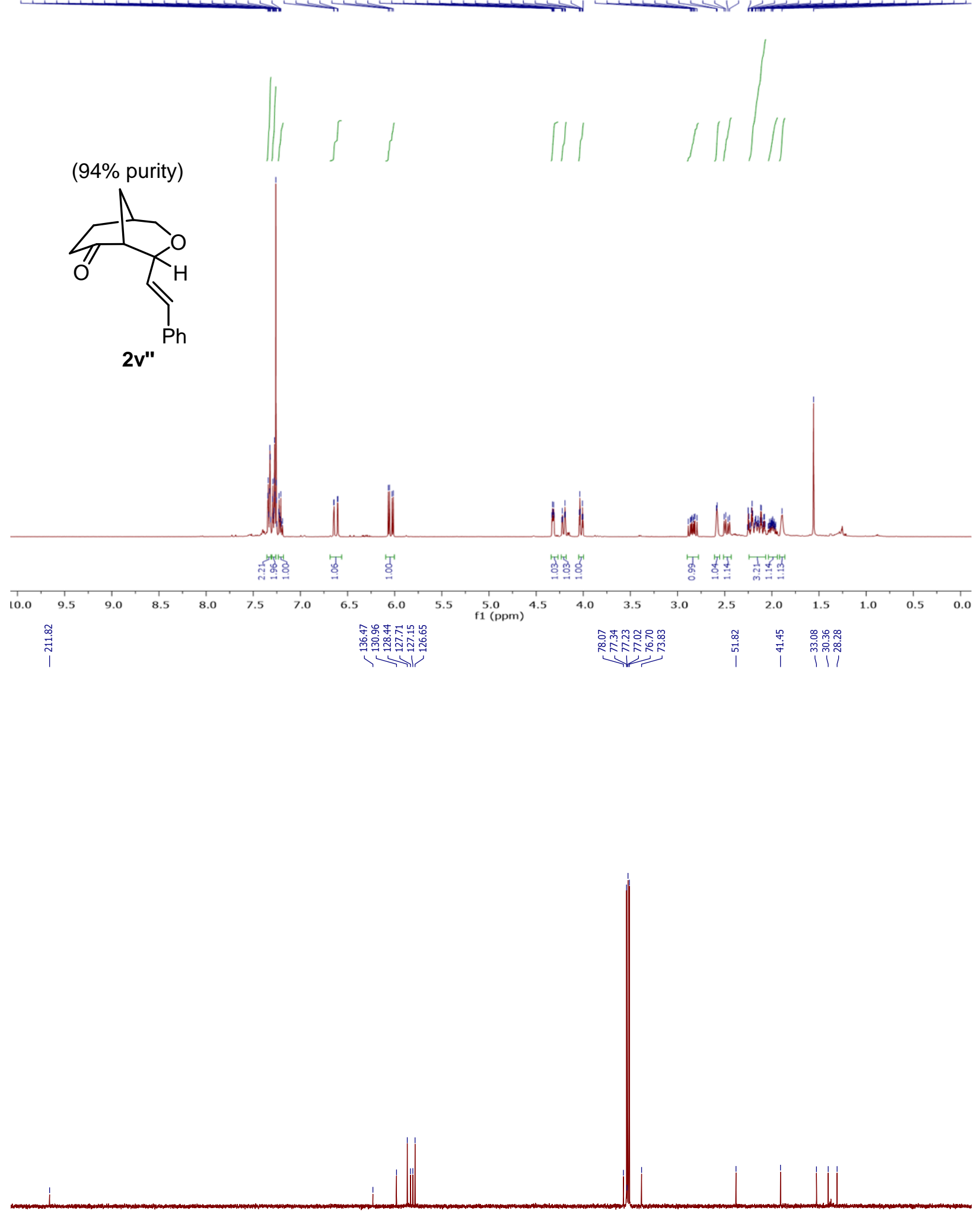

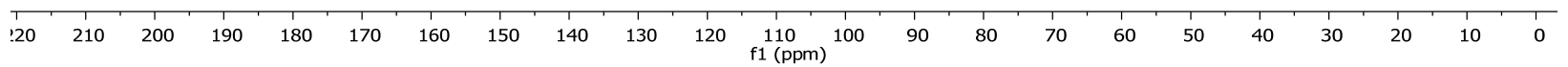



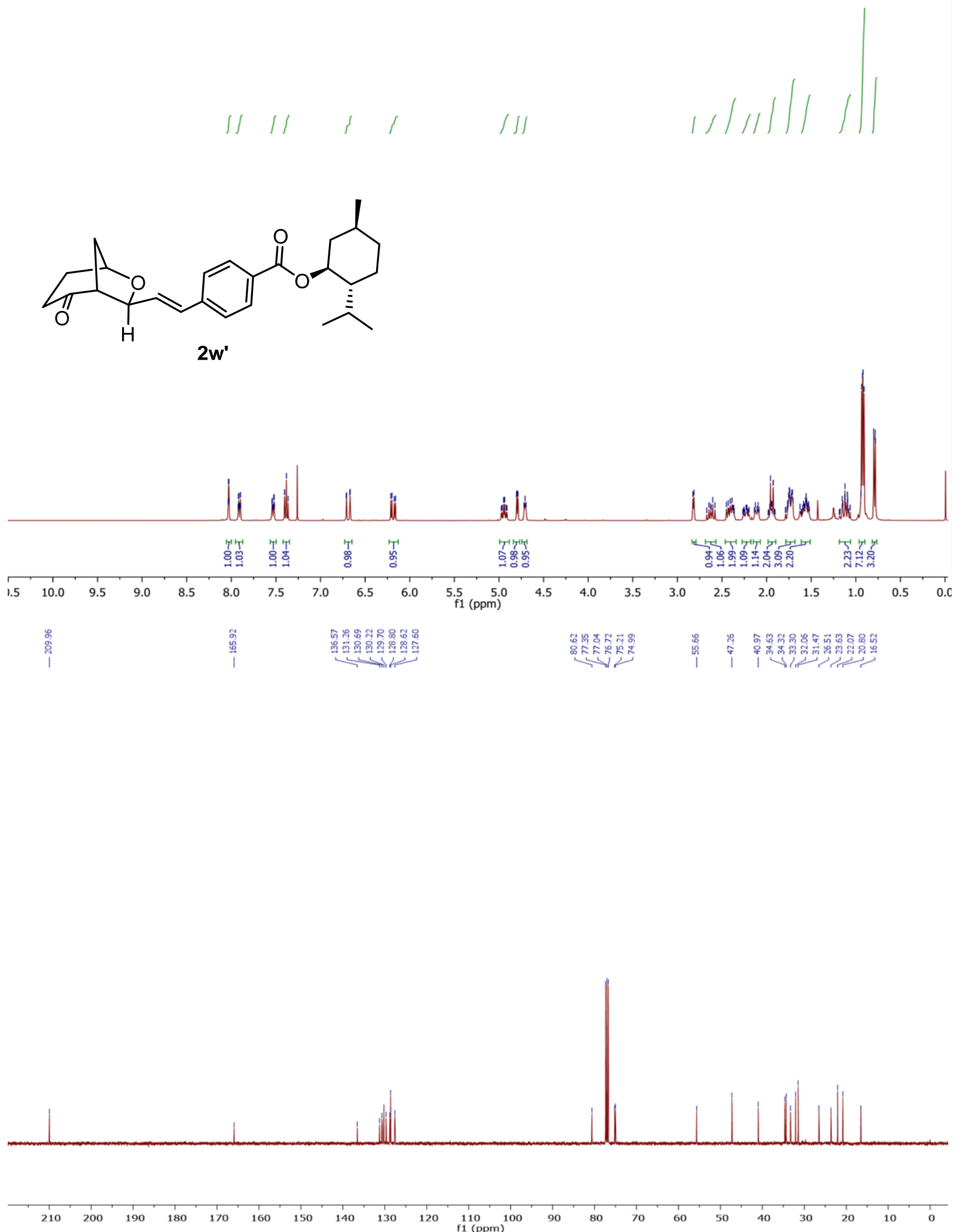

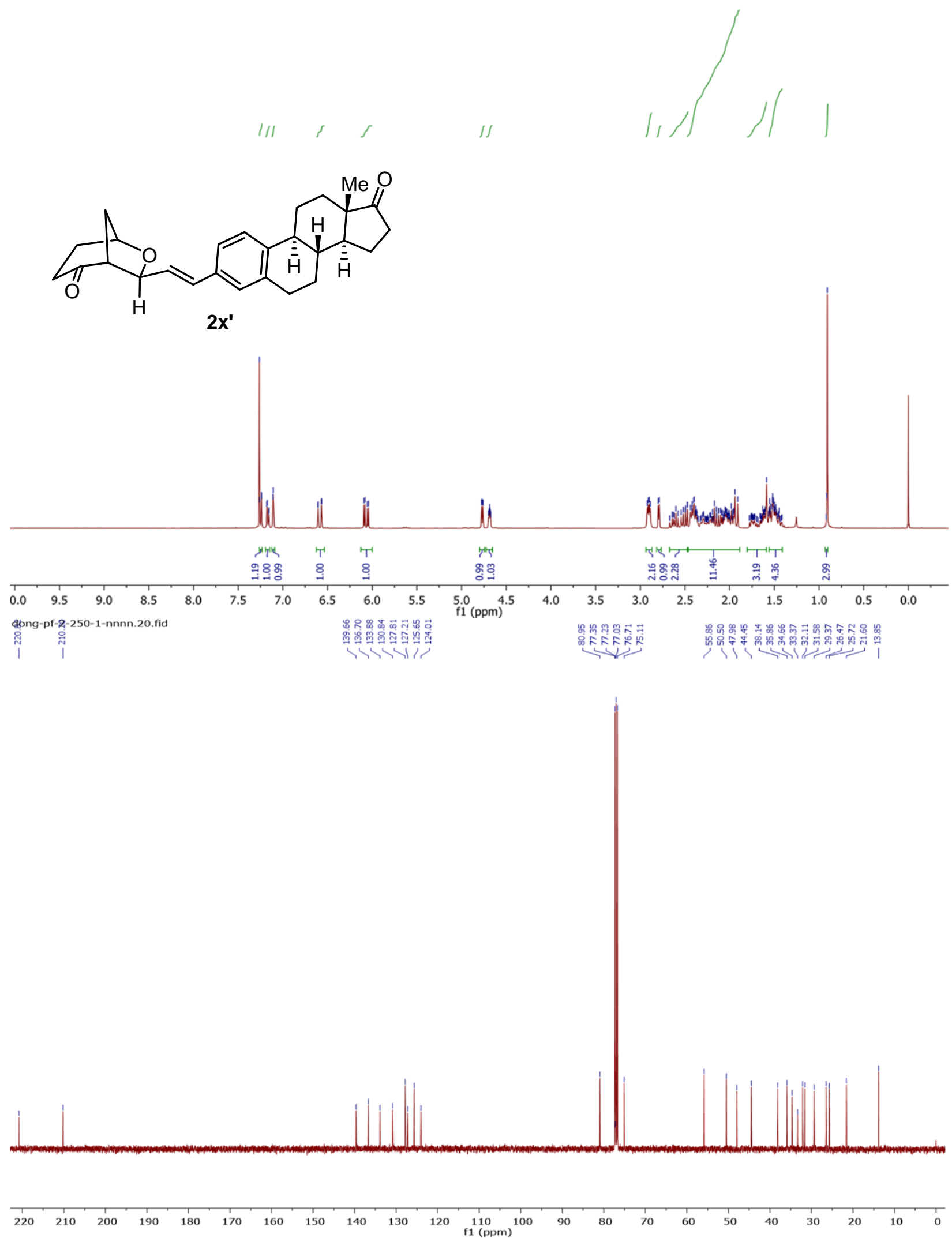

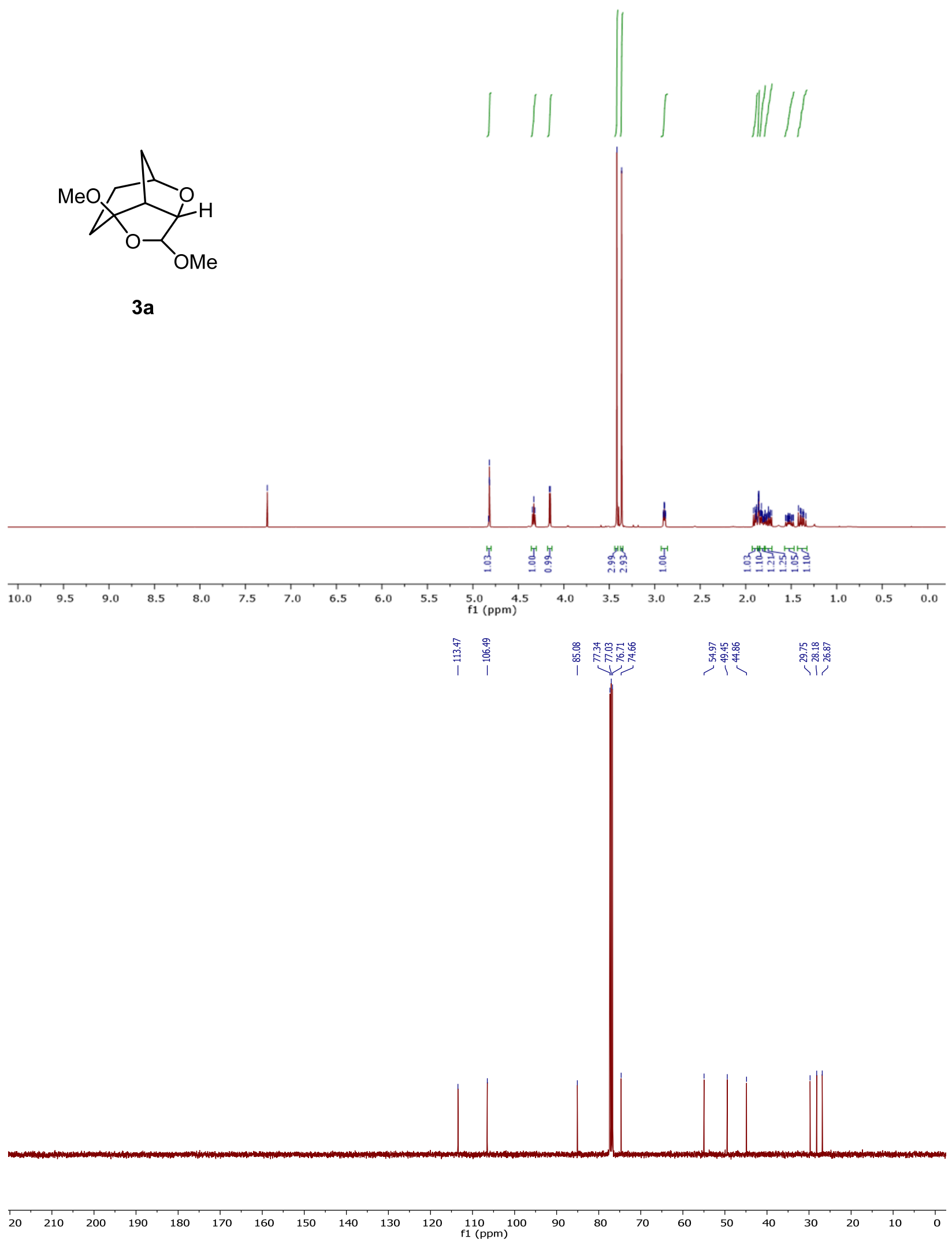

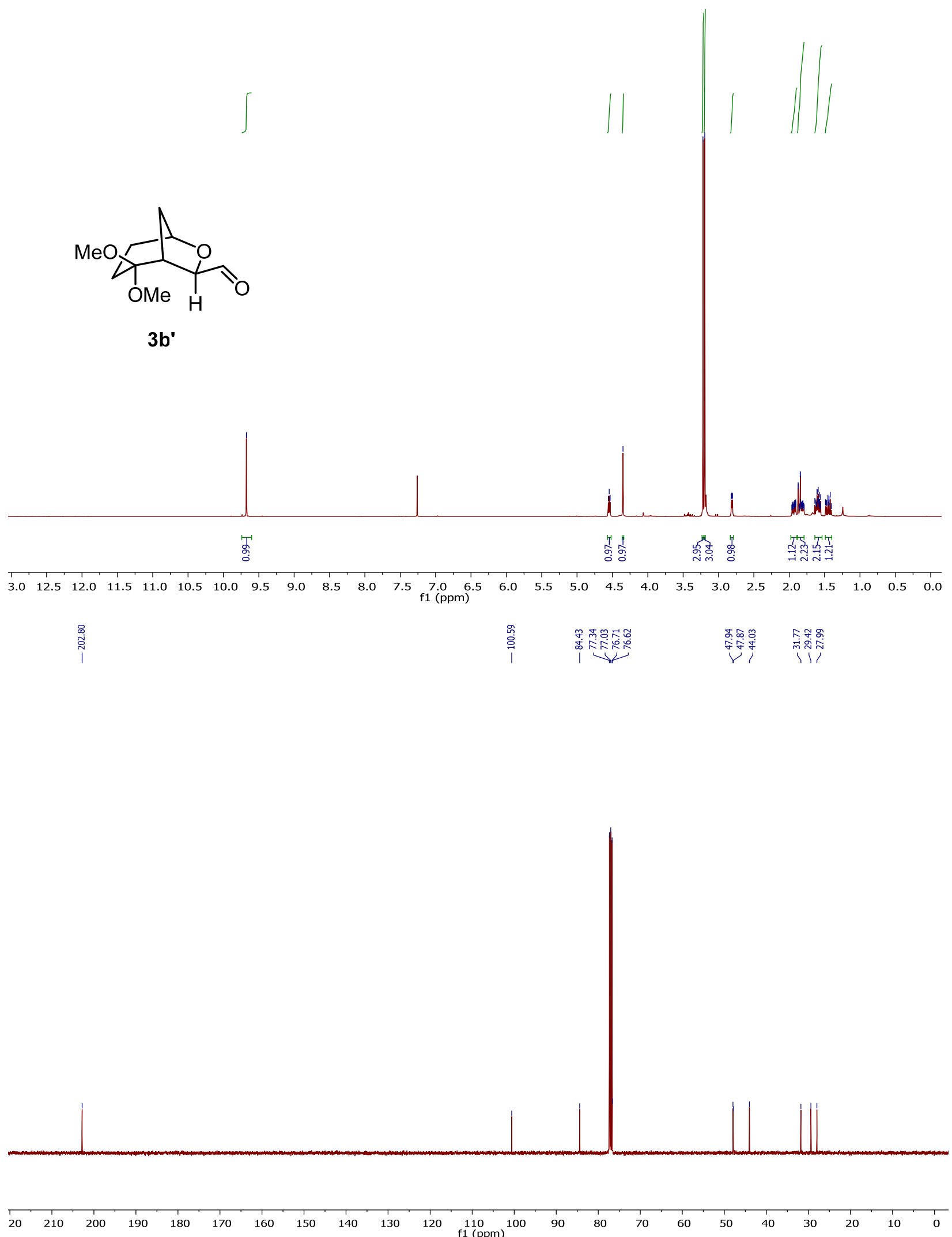

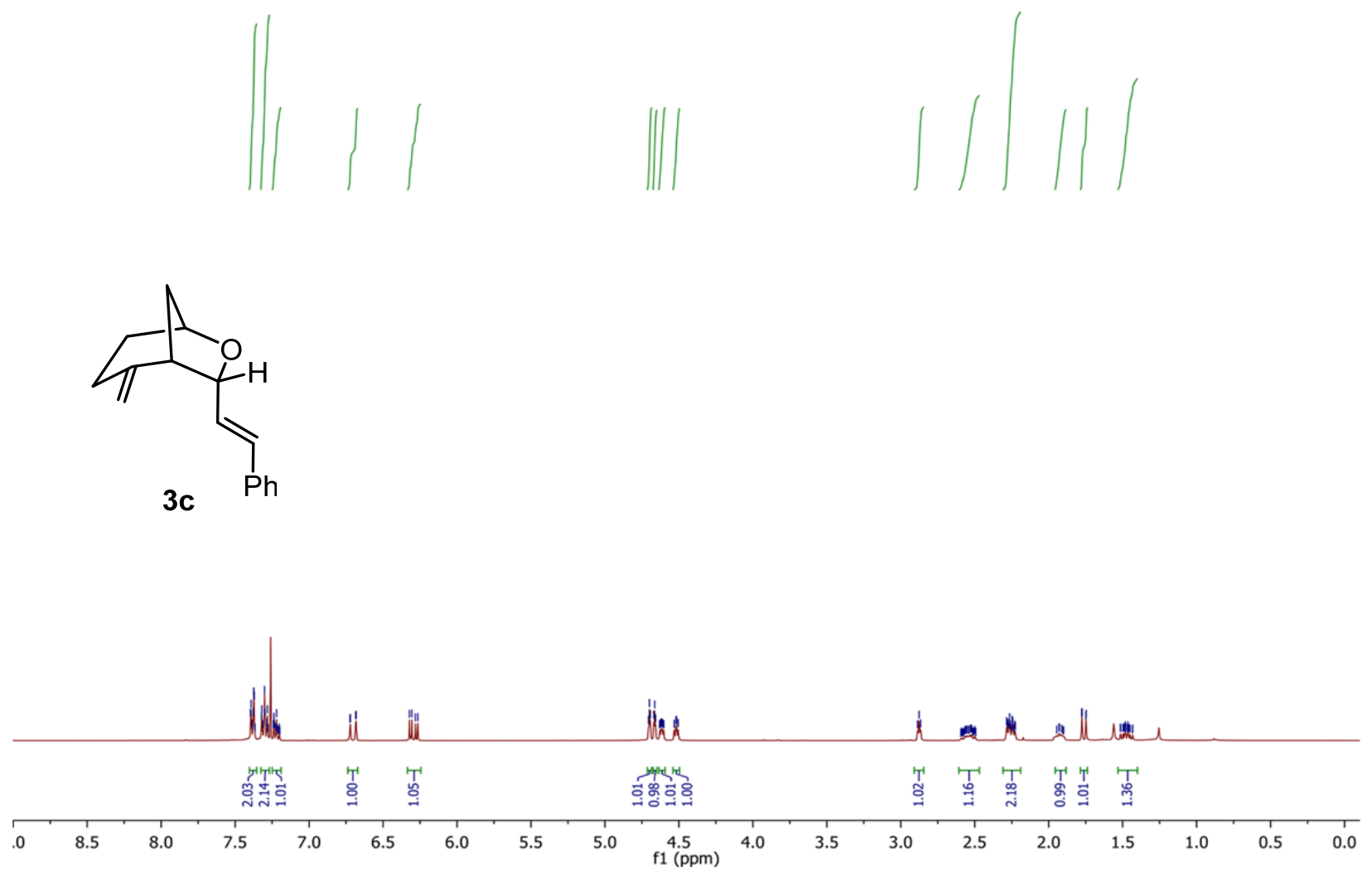

dong-pf-3-85-nnn.11.fid
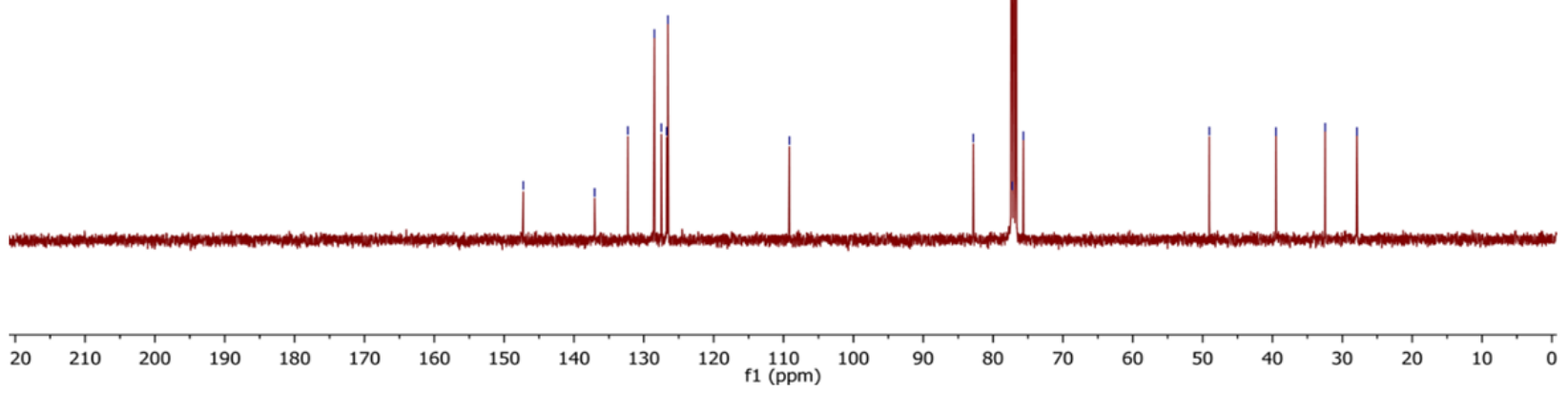

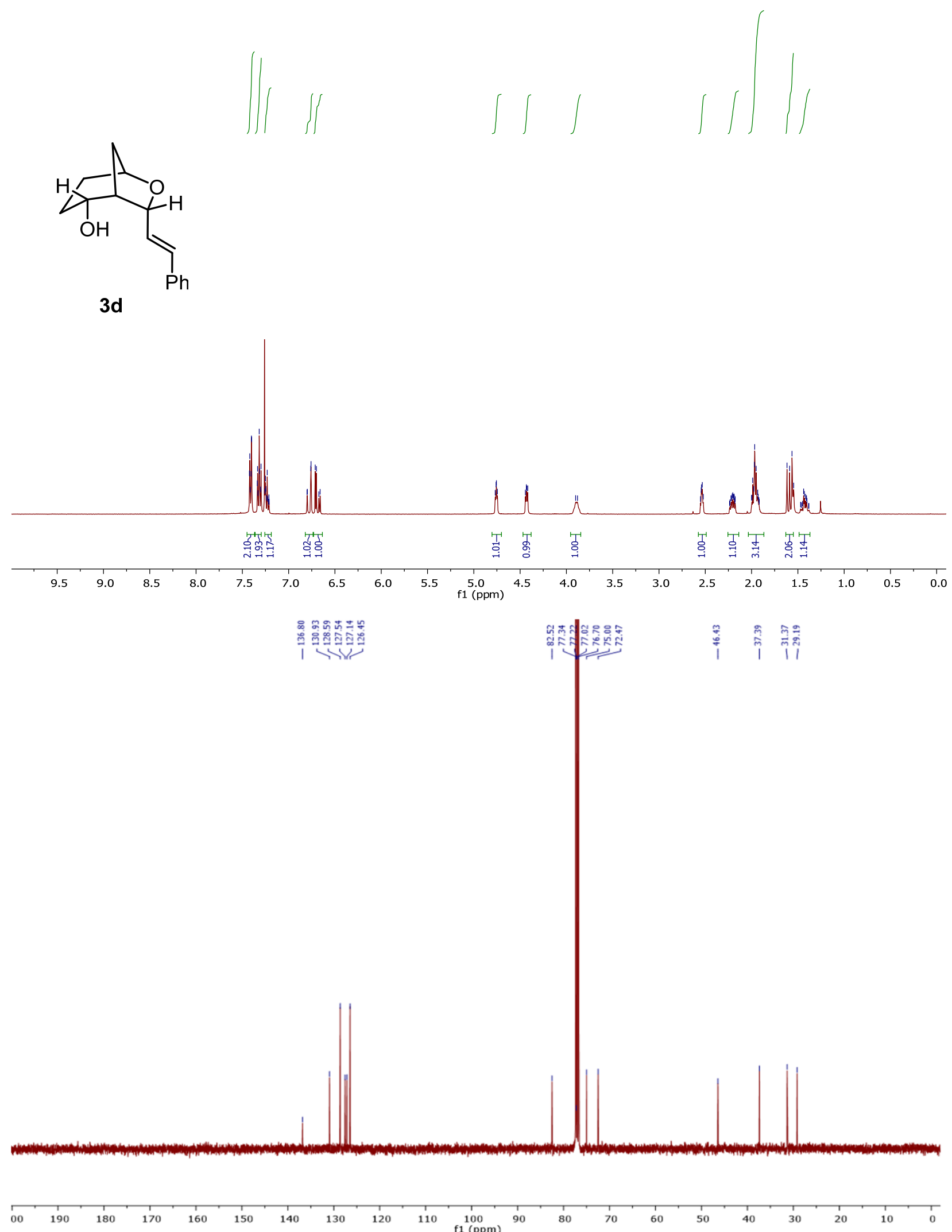

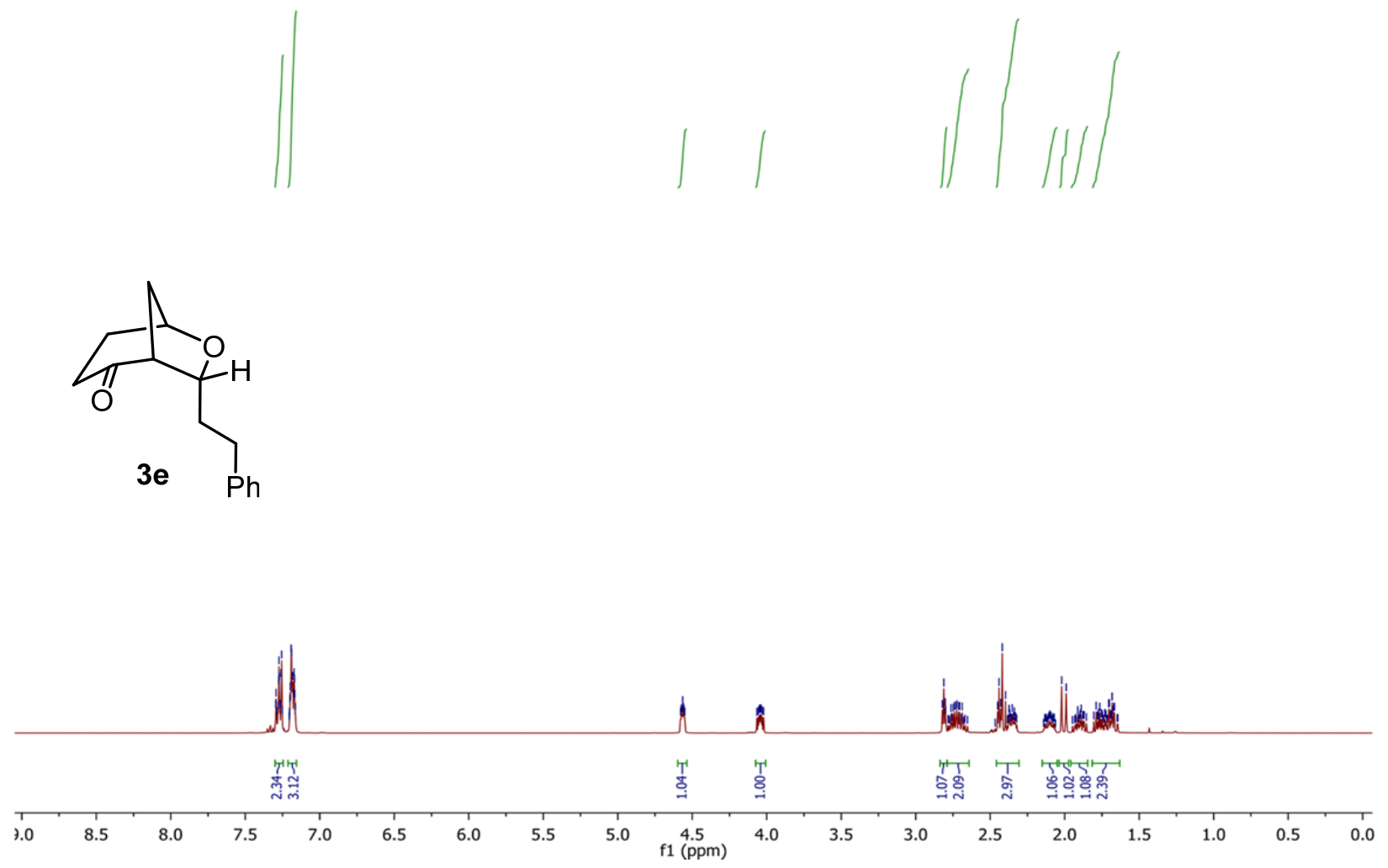

dong-pfes3-33-acnnnn.11.fid
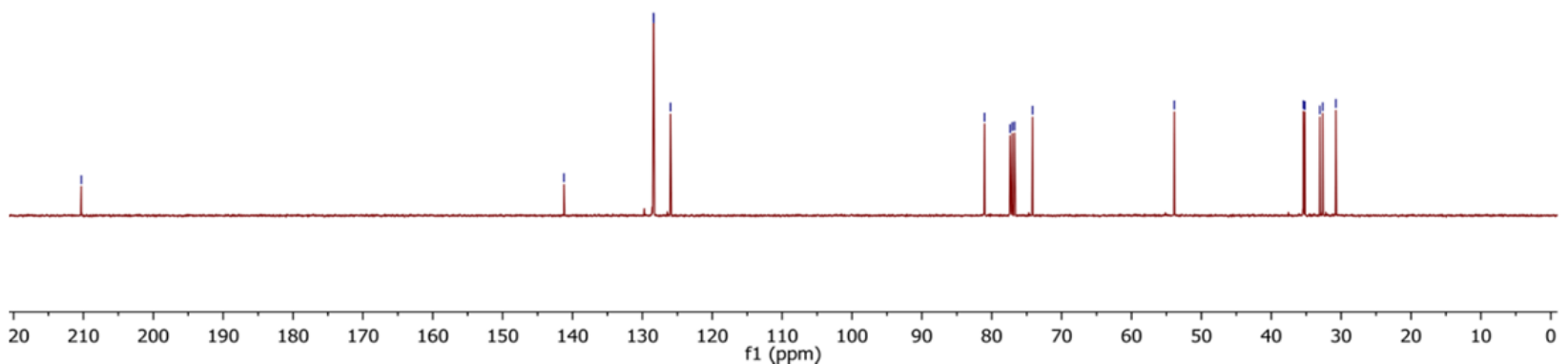

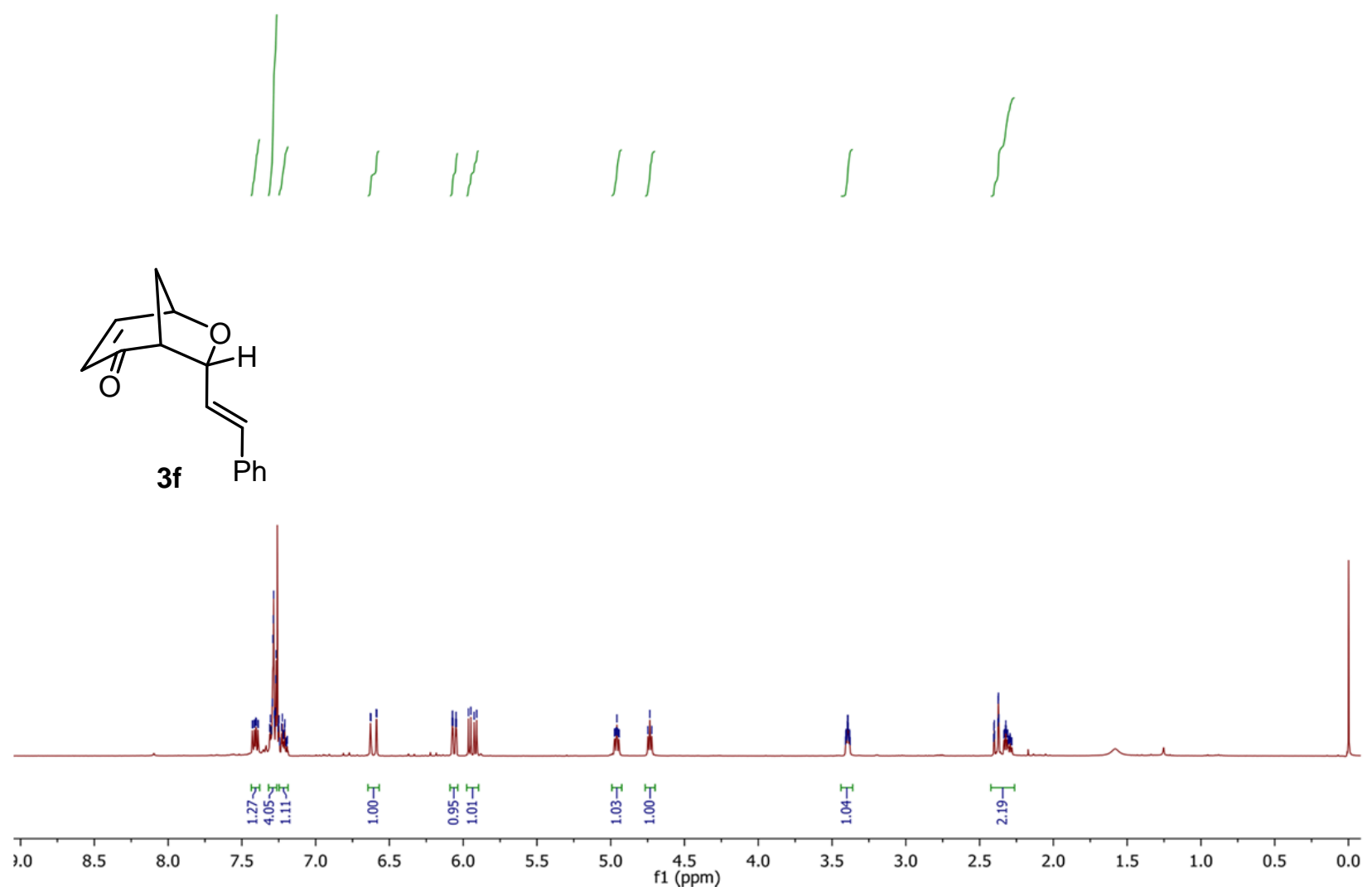

dong-pf-83-77-2-nnnnn.70.fid
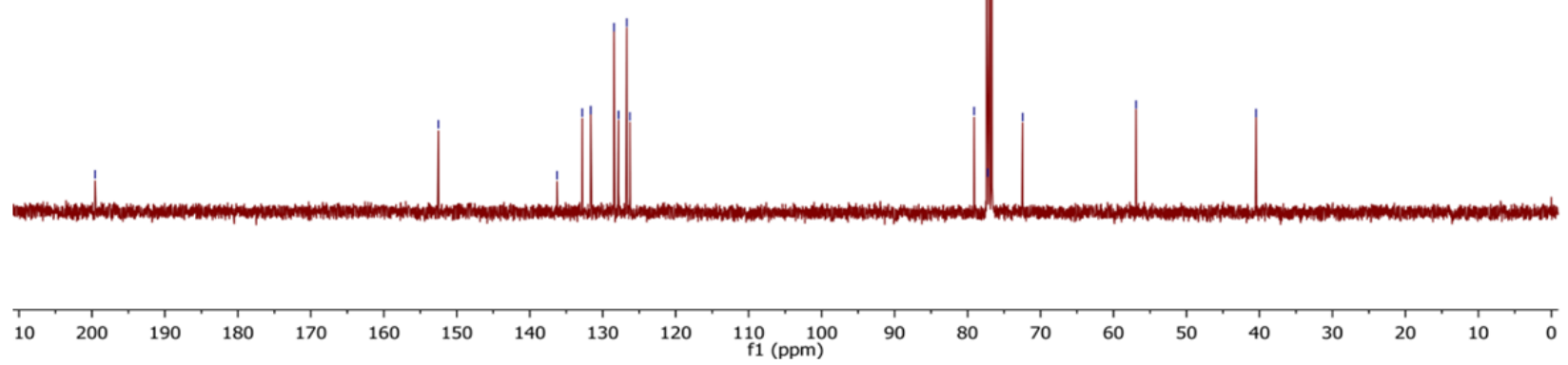

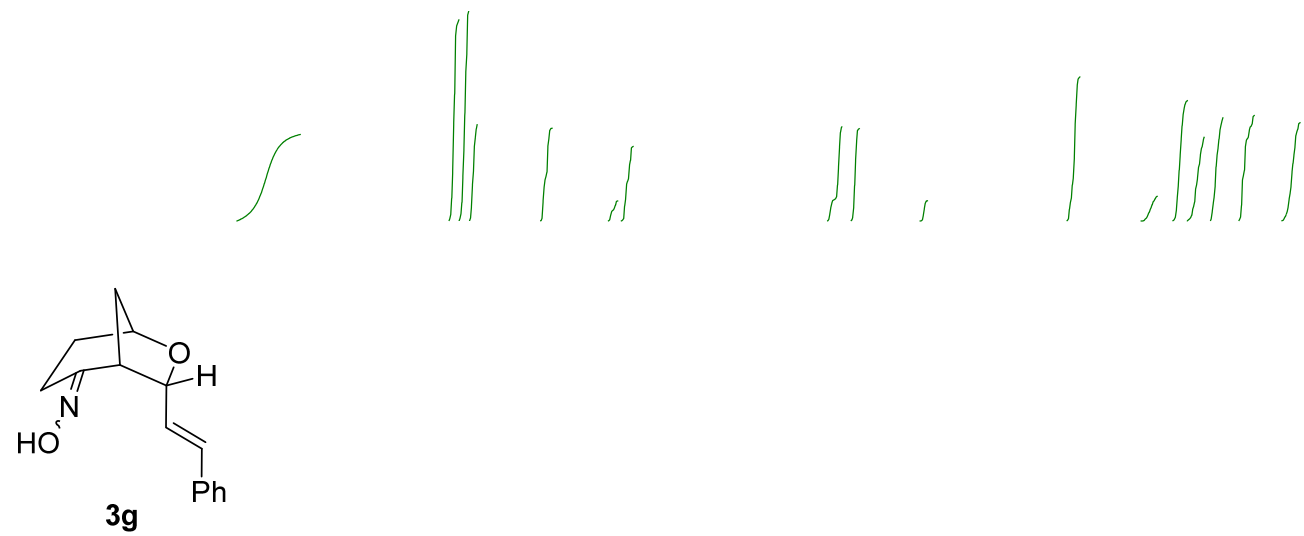

(mixture of Z/E isomer $=4: 1$ )
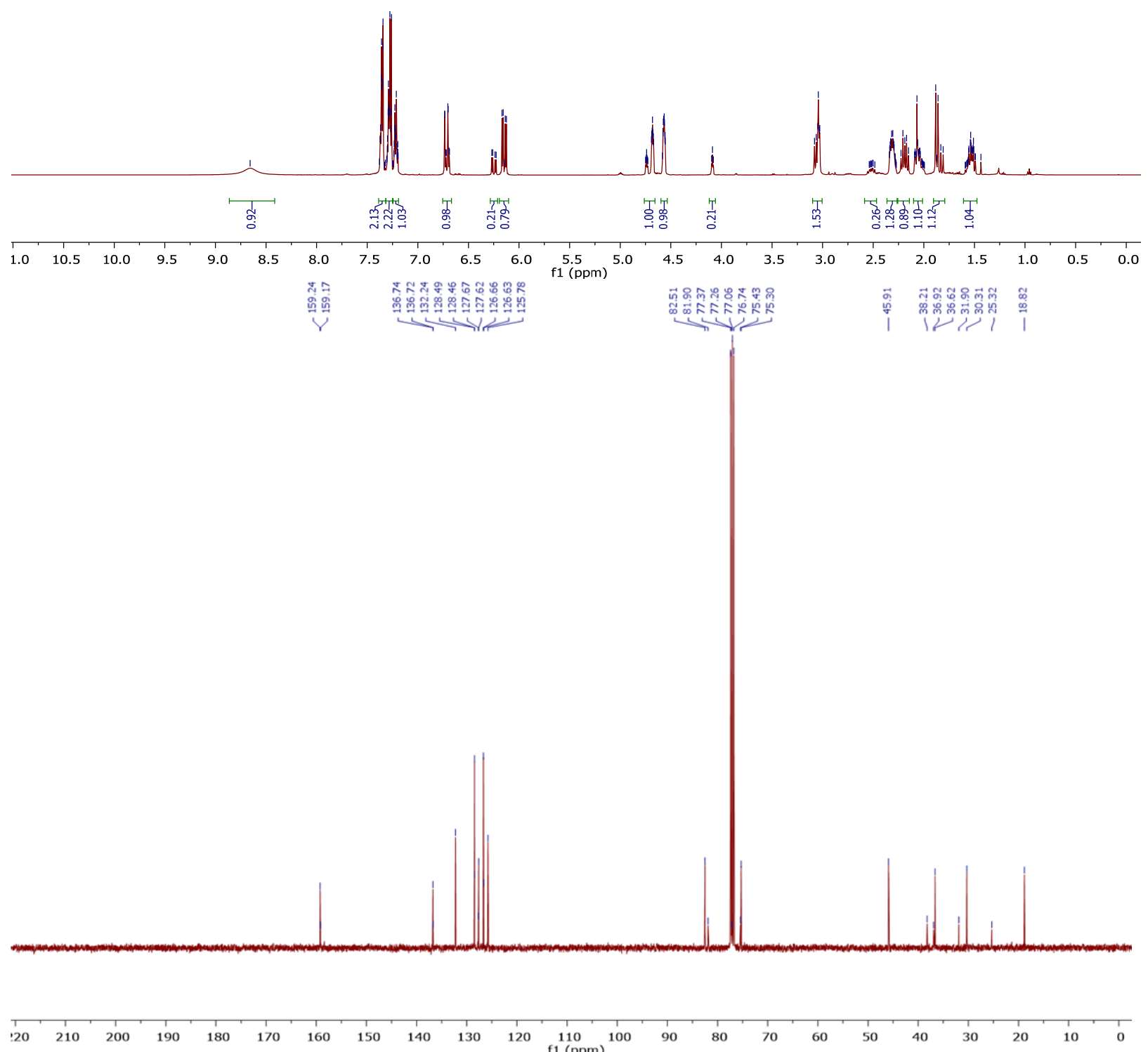


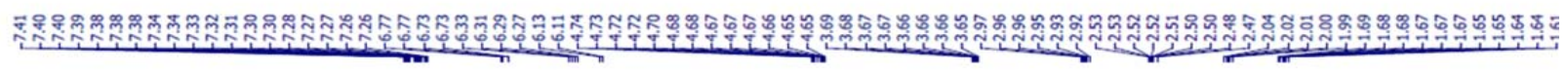
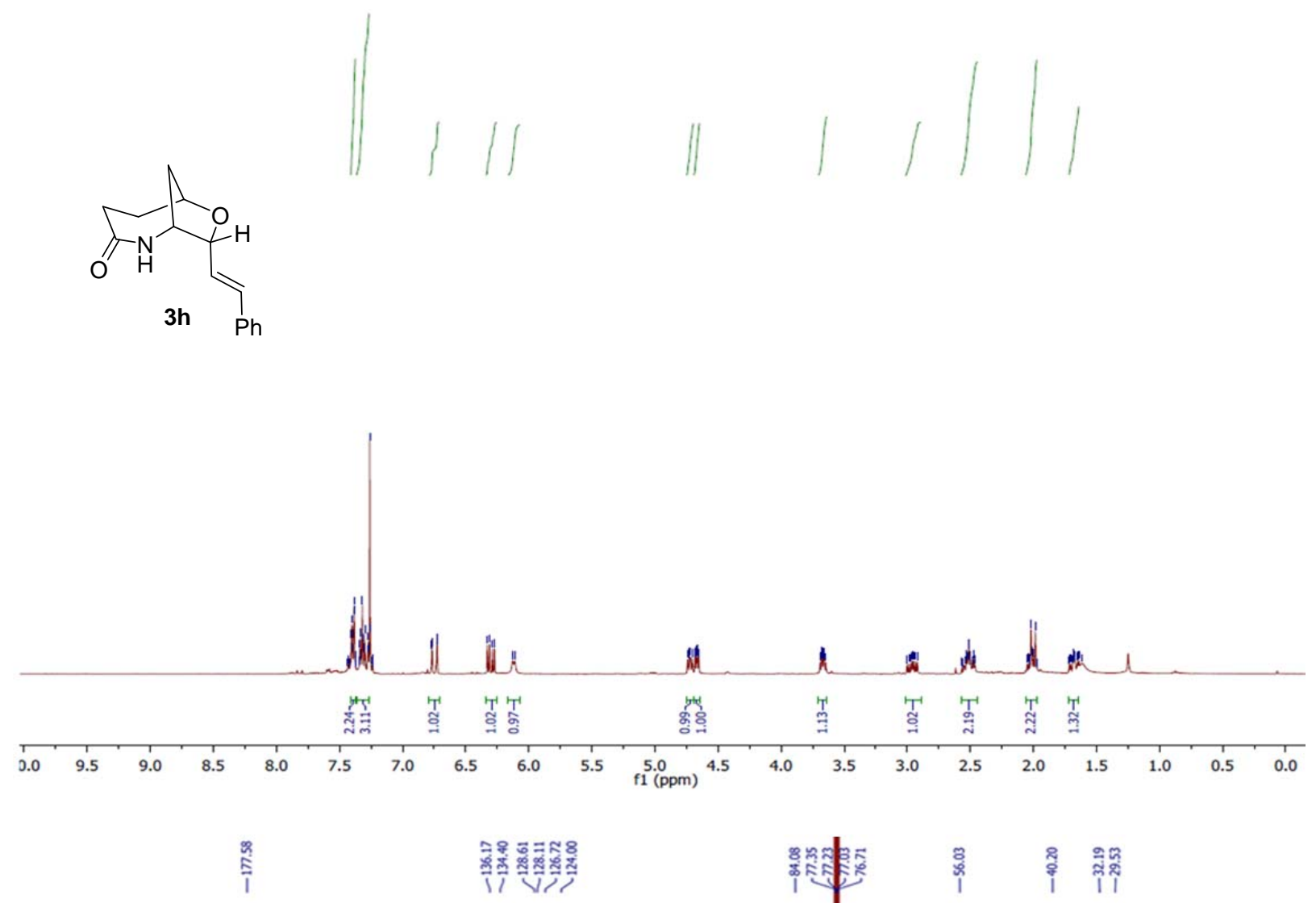

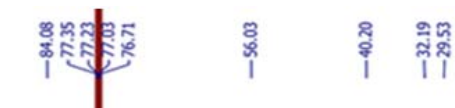

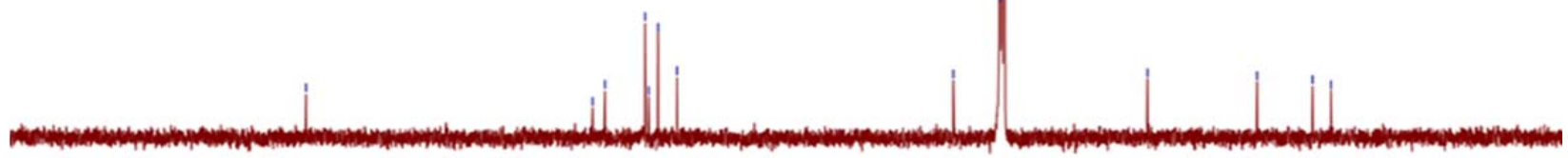

\begin{tabular}{lllllllllllllllllllllll}
\hline 20 & 210 & 200 & 190 & 180 & 170 & 160 & 150 & 140 & 130 & 120 & $\begin{array}{c}110 \\
\mathrm{f} 1(\mathrm{ppm})\end{array}$ & 100 & 90 & 70 & 60 & 50 & 40 & 30 & 20 & 10 & 0
\end{tabular} 